Doktori (Ph.D.) értekezés

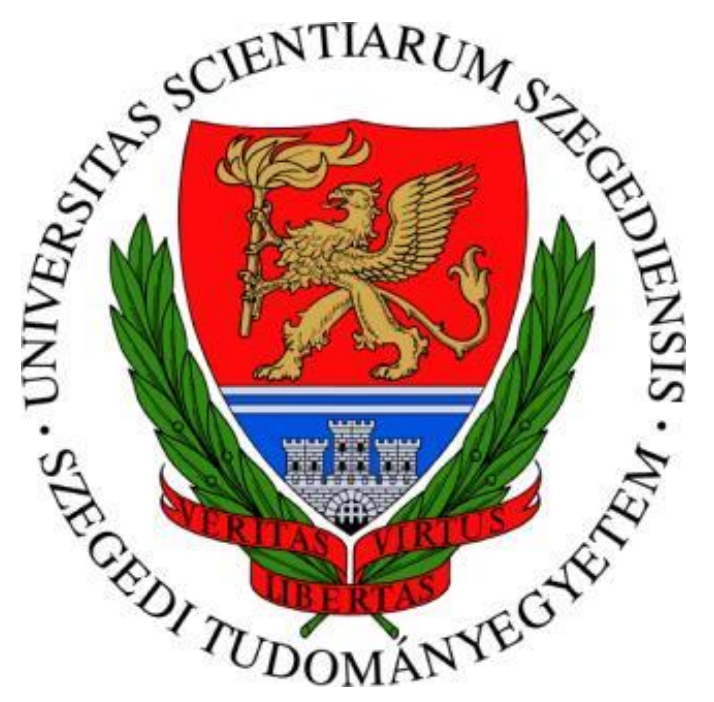

Varga Norbert

okleveles vegyész

\title{
Makromolekulás kolloidokból felépülő hatóanyag hordozó rendszerek tervezése
}

\author{
Témavezető: \\ Dr. Csapó Edit \\ egyetemi adjunktus
}

Kémia Doktori Iskola

Szegedi Tudományegyetem

Természettudományi és Informatikai Kar Fizikai Kémiai és Anyagtudományi Tanszék

Szeged 


\section{Tartalomjegyzék}

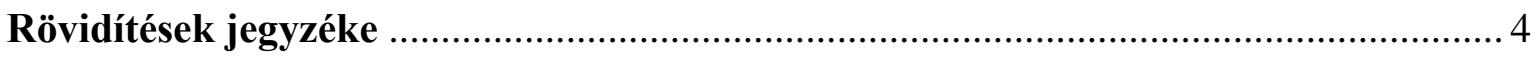

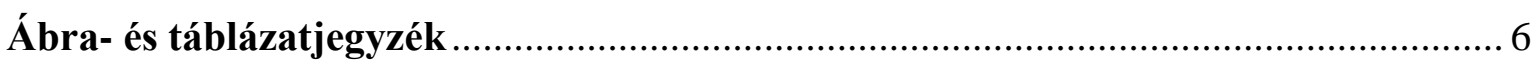

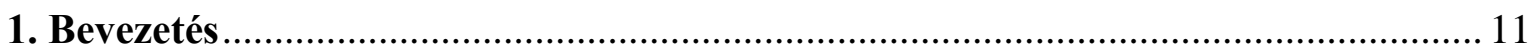

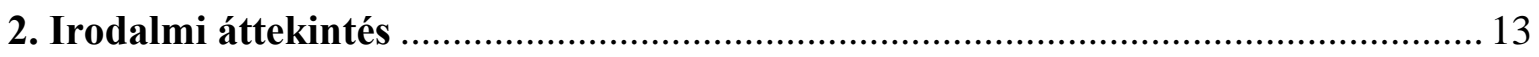

2.1. Kolloid részecskék, mint gyógyszerhatóanyag hordozók................................. 13

2.2. Makromolekulás (polimer alapú) hatóanyag hordozók.................................... 17

2.2.1. Polimer alapú nanorészecskék jellemzése................................................... 17

2.2.2. Polimer alapú nanorészecskék elöállitási lehetöségei .................................... 18

2.2.3. Polimer nanorészecskék elöállitása folyamatos áramú, áramlásos kémiai

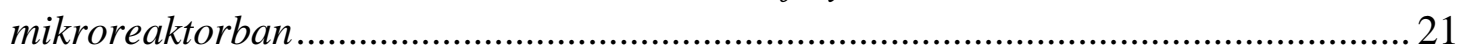

2.3. PLA/PLGA és Hialuronsav alapú rendszerek jellemzése …............................. 22

2.3.1. PLA/PLGA alapú hatóanyag hordozó rendszerek ....................................... 22

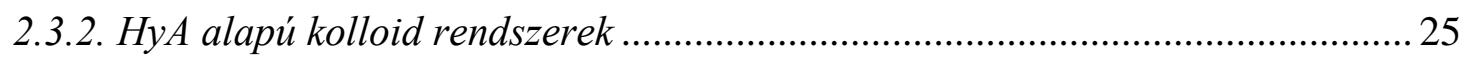

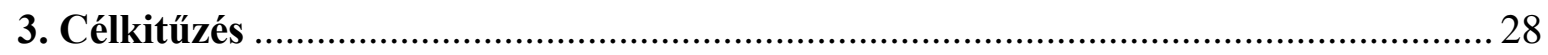

4. Felhasznált anyagok, szintézisek és vizsgálati módszerek .................................... 30

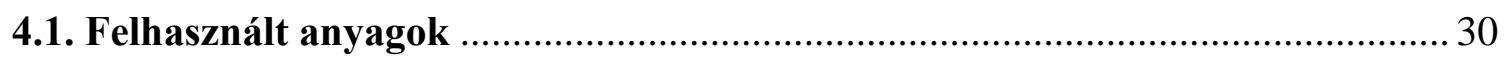

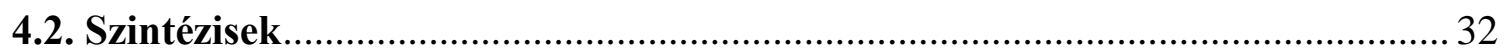

4.2.1. Poli(laktid-ko-glikolid) kopolimerek szintézise .............................................. 32

4.2.2. PLA/PLGA hordozó rendszerek szintézise nanoprecipitációs módszerrel ......... 32

4.2.3. PLGA50 részecskék elöállitása áramlásos rendszerben .................................. 34

4.2.4. Térhálósitott nátrium-hialuronát részecskék elöállitása .................................. 35

4.2.5. M-HyA/CTAB kompozit részecskék elöállítása .............................................. 35

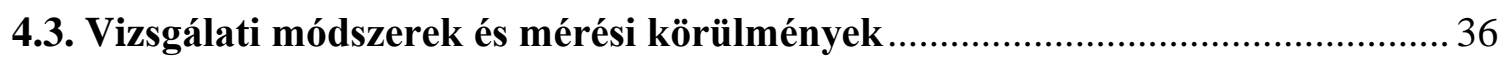

4.3.1. A hordozó rendszerek jellemzésére szolgáló módszerek és technikák ............... 36

4.3.2. Részecskék méretének és szerkezetének meghatározása ................................... 40

4.3.3. Kapszulázási hatékonyság és in vitro hatóanyag kioldódási vizsgálatok .......... 41

4.3.4. Egyéb alkalmazott müszeres technikák ......................................................... 43

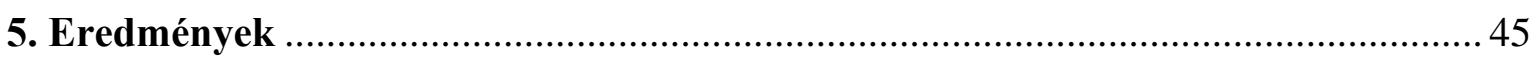

5.1. A szintetizált PLA/PLGA polimerek karakterizálása és az előállított PLA/PLGA részecskék jellemzése az oldószer, stabilizátor és hidrofilitási tulajdonságok

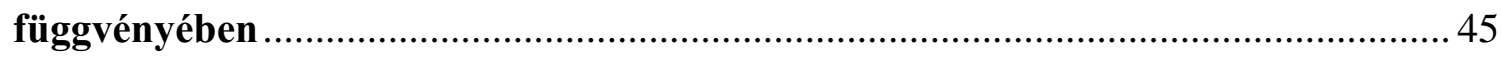

5.1.1. A szintetizált PLA és PLGA polimerek karakterizálása .................................. 45

5.1.2. Hatóanyag nélküli PLA/PLGA részecskék jellemzése ..................................... 49

5.1.3. Hatóanyag-tartalmú PLA/PLGA részecskék jellemzése .................................. 52 
5.2. Mag-héj szerkezetü TP-tartalmú PLA/PLGA részecskék előállítási protokolljának optimalizálása és szerkezeti jellemzésük

5.2.1. Nanoprecipitációs technikával elöállitott TP-tartalmú PLA/PLGA részecskék koncentráció függő elöállitási protokolljának optimalizálása. .55

5.2.2. TP-tartalmú PLGA50 részecskék elöállítása áramlásos kémiai technikával..... 60

5.2.3. TP-tartalmú PLA/PLGA részecskék szerkezeti karakterizálása. 63

5.2.4. TP in vitro kioldódási vizsgálata PLA/PLGA részecskékből 66

5.3. Keresztkötött és CTAB -dal részlegesen hidrofóbizált HyA nanorészecskék előállítása, szerkezetvizsgálata és felhasználásuk KP kapszulázására .68

5.3.1. Keresztkötött HyA nanorészecskék elöállitása és karakterizálása. .68

5.3.2. CTAB -dal neutralizált HyA nanorészecskék elöállitása és karakterizálása ..... 71

5.3.3. HyA alapú rendszerek reológiai tulajdonságai..... .75

5.3.4. HyA alapú rendszerek in vitro hatóanyag kioldódási tulajdonságai 79

5.4. Hialuronsav - kitozán poliszacharid alapú hordozó rendszerek előállítása és jellemzése 81

5.4.1. HyA-Chit között kialakuló elektrosztatikus kölcsönhatások jellemzése 81

5.4.2. HyA-Chit hatóanyag hordozó rendszerek elöállitása és jellemzése. 86

6. Összefoglaló .89

7. Summary .93

8. Irodalomjegyzék .97

9. Melléklet 106

10. Köszönetnyilvánítás. 109

11. Publikációs lista 110 


\section{Rövidítések jegyzéke}

Anti-EGFR: anti epidermális növekedési faktor receptor

BSA: marha szérum albumin

Chit: kitozán

cl-HyA: keresztkötött hialuronsav

CTAB: cetil-trimetil-ammónium-bromid

DLS: dinamikus fényszórás

DSC: differenciális pásztázó kalorimetriás

DTA: differenciális termoanalitika

DTG: derivatív termogravimetria

EDC metil-jodid: 1-[3-(dimetil-amino)propil]-3-etil-karbodiimid-metil-jodid

EDEA: 2,2'(etiléndioxi)bisz(etilamin)

FT-IR: Fourier-transzformációs infravörös (spektroszkópia)

GA: glikolid

H-Chit: nagy molekulatömegü kitozán

H-HyA: nagy molekulatömegü nátrium-hialuronát

HRTEM: nagyfelbontású transzmissziós elektronmikroszkópia

HTCC: $N$-(2-hidroxi-propil)-3-trimetil-ammónium-kloriddal módosított kitozán

HyA: hialuronsav

IBU: ibuprofen

ITC: izoterm titrációs kalorimetria

KP: ketoprofen

KYNA: kinurénsav

LA: laktid

LDH: réteges kettős hidroxid

M-Chit: közepes molekulatömegü kitozán

Mg/Al LDH: magnézium/alumínium réteges kettős hidroxid

M-HyA: közepes molekulatömegü nátrium-hialuronát

Milli-Q víz: ultratiszta Milli-Q víz (fajlagos ellenállás: $18,2 \mathrm{~m} \Omega \times \mathrm{cm} 25^{\circ} \mathrm{C}$-on)

NMR: mágneses magrezonancia (spektroszkópia)

NSAID: nem-szteroid gyulladáscsökkentő hatóanyag

O/V: olaj a vízben emulzió

PBS: foszfát puffer $(\mathrm{pH}=7,4,0,9 \% \mathrm{NaCl})$ 
PCL: polikaprolakton

PDT: fotodinamikai terápia

PEC: polielektrolit komplex

PEG: polietilén-glikol

PEI: polietilénimin

PLA: poli(tejsav)

PLGA: poli(laktid-ko-glikolid)

PLGA50: poli(laktid-ko-glikolid) (laktid:glikolid arány 50:50)

PLGA65: poli(laktid-ko-glikolid) (laktid:glikolid arány 65:35)

PLGA75: poli(laktid-ko-glikolid) (laktid:glikolid arány 75:25)

PLUR: Pluronic F127

PNIPAM: poli( $N$-izopropil-akrilamid)

PNIPAM- $b$-PCL- $b$-PNIPAM: poli( $N$-izopropil-akrilamid)-poli( $\varepsilon$-kaprolakton $)$ - $\operatorname{poli}(N$ izopropil-akrilamid)

PSS: nátrium-polisztirol-szulfonát

PVA: polivinil alkohol

RESOLV: szuperkritikus folyadék gyors expanziója folyadékban

RESS: szuperkritikus folyadék gyors expanziója

ROP: gyürüfelnyitásos polimerizáció

SEM: pásztázó elektronmikroszkópia

SH-HyA: tiolcsoporttal rendelkező hialuronsav

TEM: transzmissziós elektronmikroszkópia

TG: termogravimetria

TP: ( \pm )- $\alpha$-tokoferol

TPGS: $D$ - $\alpha$-tokoferol-polietilén-glikol-1000-szukcinát

TPP: tripolifoszfát

UCNPs: felkonvertáló nanorészecskék

UV-Vis: ultraibolya-látható (spektrofotometria)

V/O/V: víz/olaj/víz duplaemulzió

V/O: víz az olajban emulzió

$\zeta$-potenciál: elektrokinetikai potenciál (Zéta-potenciál) 


\section{Ábra- és táblázatjegyzék}

1. ábra: A ,polimer alapú hordozó nanorészecskék” témában megjelent publikációk számának változása 1996-2019 között 5281db publikáció alapján

2. ábra: A nanoszerkezetü hatóanyag hordozót-tartalmazó termékek fejlődése a liposzómális hordozórendszerek megismerésétől napjainkig [9] .................................... 14

3. ábra: Hatóanyag hordozóként alkalmazható rendszerek sematikus ábrái 14

4. ábra: BSA/HyA komplex kolloid részecskék előállításának sematikus ábrája (bal oldal) és a képződő kolloid részecskék szerkezeti tanulmányozásának eredményei az alkalmazott $\mathrm{m}_{\mathrm{BSA}} / \mathrm{m}_{\text {HyA }}$ tömegarány függvényében (jobb oldal) [25] 16

5. ábra: Polimer alapú hordozó rendszerek előállítási lehetőségei makromolekulákból.... 18 6. ábra: Polimer részecskék előállítására alkalmazott hagyományos technika (bal oldal) és a folyamatos áramlásos mikroreaktor általános sematikus ábrája (jobb oldal) 21

7. ábra: PLA/PLGA makromolekulák gyürüfelnyitásos polimerizációval (ROP) történő szintézisének sematikus ábrája .....

8. ábra: HyA és SH-HyA-héjjal rendelkező inzulin/HTCC részecskék előállítása folyamatos müködésű „nanokomplexálási” technikával és a részecskékről készített TEM képek [101]

9. ábra: A hordozó rendszerek előállításához használt polimerek monomer egységei és a hatóanyagok szerkezeti képletei

10. ábra: A PLGA50 kopolimer alapú kolloid részecskék előállításához használt Syrris Asia Flow áramlásos rendszer sematikus ábrája

11. ábra: A PLA/PLGA polimerek és a ciklikus dimerek (A) FT-IR spektrumai és (B) DSC görbéi

12. ábra: (A) A PLGA65 és a PLGA75 kopolimerek törésmutató értékei a koncentráció függvényében és (B) a Rayleigh-Gans-Debye egyenlet (1. egyenlet) grafikus ábrázolása 47 13. ábra: 1,4-dioxánban oldott (A) PLGA75 és (B) PLGA65 precipitációs görbéi (titrálószer: Milli-Q víz, titrálandó oldat: $\mathrm{V}=5 \mathrm{~mL}, \mathrm{C}_{\mathrm{PLGA}}=5 \mathrm{mg} / \mathrm{mL}$ ) 48

14. ábra: A PLA/PLGA polimerek peremszög értékei a felületre cseppentett $10-10 \mu \mathrm{L}$ térfogatú vízcseppekre meghatározva

15. ábra: A különböző stabilizátorok mellett előállított PLGA75 részecskék reprezentatív $\zeta$ potenciál értékei tisztítás (A) előtt és (B) után (szerves fázis: V=1,5 mL, cPLGA75=10 mg/mL, vizes fázis: $\mathrm{V}=15 \mathrm{~mL}, \mathrm{c}_{\text {stabilizátor }}=0,1 \mathrm{mg} / \mathrm{mL}$ ). .51 
16. ábra: Különböző stabilizátorok felhasználásával előállított PLA részecskék reprezentatív TEM felvételei eltérő nagyítások mellett (szerves fázis: aceton, $\mathrm{c}_{\mathrm{PLA}}=10$ $\mathrm{mg} / \mathrm{mL}, \mathrm{V}=1,5 \mathrm{~mL}$, vizes fázis: $\mathrm{c}_{\text {stabilizátor }}=0,1 \mathrm{mg} / \mathrm{mL}, \mathrm{V}=15 \mathrm{~mL}$ )

17. ábra: Nanoprecipitációs eljárással előállított, hatóanyag-tartalmú PLA és PLGA részecskék TEM képei és a feltételezhető szerkezet sematikus (nem méretarányos) ábrái (szerves fázis: $c_{P L A} / P_{L G A}=10 \mathrm{mg} / \mathrm{mL}, V=1,5 \mathrm{~mL}$; vizes fázis: $C_{P L U R}=0,1 \mathrm{mg} / \mathrm{mL}, V=15$ $\mathrm{mL} ; \mathrm{m}_{\text {hatóanyag }}=7,5 \mathrm{mg}$ )

18. ábra: Nanoprecipitációval előállított TP-tartalmú PLA részecskékről készült reprezentatív TEM képek a különböző komponens koncentrációk mellett (PLA függés: $\mathrm{c}_{\mathrm{TP}}=$ $2,5 \mathrm{mg} / \mathrm{mL}, \mathrm{c}_{\text {PlUR }}=0,1 \mathrm{mg} / \mathrm{mL}$, TP függés: $\mathrm{c}_{\text {PLA }}=10 \mathrm{mg} / \mathrm{mL}, c_{\text {PLUR }}=0,1 \mathrm{mg} / \mathrm{mL}$, PLUR függés: $\mathrm{c}_{\mathrm{PLA}}=10 \mathrm{mg} / \mathrm{mL}, \mathrm{c}_{\mathrm{TP}}=2,5 \mathrm{mg} / \mathrm{mL}$ )

19. ábra: (A) TP- és (B) PLA- tartalmú oldatok turbiditás értékei a PLUR koncentráció függvényében (vizes közeg, $\mathrm{T}=25^{\circ} \mathrm{C}, \mathrm{c}_{\mathrm{TP}}=0,25 \mathrm{mg} / \mathrm{mL}, \mathrm{c}_{\mathrm{PLA}}=0,25 \mathrm{mg} / \mathrm{mL}$ ) 58

20. ábra: Nanoprecipitációval előállított TP- tartalmú PLA/PLGA részecskék méreteloszlási görbéi és a PLGA75/TP és PLGA65/TP mintákról készült TEM felvételek $\left(\mathrm{c}_{\mathrm{PLGA}}=10 \mathrm{mg} / \mathrm{mL}, \mathrm{c}_{\mathrm{TP}}=2,5 \mathrm{mg} / \mathrm{mL}, \mathrm{c}_{\mathrm{PLUR}}=0,1 \mathrm{mg} / \mathrm{mL}\right)$

21. ábra: Nanoprecipitációval előállított TP-nélküli és TP-tartalmú PLGA50 részecskék méreteloszlása és TEM felvételei (szerves fázis: $\mathrm{c}_{\mathrm{PLGA} 50}=5 \mathrm{mg} / \mathrm{mL} \mathrm{c}_{\mathrm{TP}}=1,25 \mathrm{mg} / \mathrm{mL}$; vizes fázis: $\left.c_{P L U R}=0,1 \mathrm{mg} / \mathrm{mL}\right)$.

22. ábra: Különböző $\mathrm{V}_{1}: \mathrm{V}_{2}$ áramlási sebességeken elkészített TP-tartalmú PLGA50 részecskék reprezentatív TEM képei (szerves fázis: $\mathrm{c}_{\mathrm{PLGA} 50}=5 \mathrm{mg} / \mathrm{mL}, \mathrm{c}_{\mathrm{TP}}=1,25 \mathrm{mg} / \mathrm{mL}$; vizes fázis: $\left.\mathrm{C}_{\mathrm{PLUR}}=0,1 \mathrm{mg} / \mathrm{mL}\right)$.

23. ábra: A PLA és TP-tartalmú PLA részecskék liofilizált pormintáinak FT-IR spektrumai (szerves fázis: $\mathrm{c}_{\mathrm{PLA}}=10 \mathrm{mg} / \mathrm{mL}$, vizes fázis: $\mathrm{c}_{\mathrm{PLUR}}=0,1 \mathrm{mg} / \mathrm{mL}$ )

24. ábra: TP turbiditás változása PLUR-tartalmú vizes $\left(25^{\circ} \mathrm{C}(\mathbf{A})\right)$ és $\mathrm{PBS}(\mathrm{pH}=7,4 ; 0,9$ $\mathrm{w} / \mathrm{w} \% \mathrm{NaCl} ; 25^{\circ} \mathrm{C}(\mathbf{B})$ és $\left.37{ }^{\circ} \mathrm{C}(\mathbf{C})\right)$ oldatokban $\left(\mathrm{c}_{\mathrm{TP}}=0,05 \mathrm{mg} / \mathrm{mL}\right)$

25. ábra: A PLUR cmc értékének meghatározása Milli-Q vizes $(\boldsymbol{\Delta})$ és PBS $(\bullet)$ közegben $\left(\mathrm{t}=25^{\circ} \mathrm{C}\right)$.

26. ábra: A különböző TP-tartalmú PLA/PLGA részecskékből a hatóanyag PBS közegben regisztrált kioldódási görbéi $(\bullet$ jelölt), illetve a mérési pontokra (A) Korsmeyer-Peppas és (B) Weibull kinetikai modellekkel történő illesztések (szaggatott vonallal jelölt) $\left(\mathrm{T}=37^{\circ} \mathrm{C}\right.$, $\left.\mathrm{pH}=7,4 ; 0,9 \% \mathrm{NaCl} ; \mathrm{C}_{\mathrm{PLUR}}=1 \mathrm{mg} / \mathrm{mL}\right)$ (\#: folyamatos áramlásos technikával előállított részecskék). .66 
27. ábra: A liofilizált és 75\% -ban keresztkötött M-HyA (cl-M-HyA/75\%) és a kiindulási M-HyA FT-IR spektrumainak részlete (bal oldal) illetve a szintézis sematikus ábrája (jobb oldal)

28. ábra: A 75\% -ban keresztkötött M-HyA (cl-M-HyA/75\% (piros)), a keresztkötő EDEA komponens (fekete) és a M-HyA (kék) (A) TG, (B) DTG és (C) DSC görbéi 70

29. ábra: (A) A különböző mértékben keresztkötött M-HyA nanorészecskék méreteloszlása, illetve (B) cl-M-HyA/100\% részecskékröl készült TEM felvétel és (C) a meghatározott számszerinti méreteloszlás .71

30. ábra: A HyA CTAB-dal történő neutralizálásának sematikus ábrája. .71

31. ábra: (A) M-HyA nélküli és (B) M-HyA tartalmú rendszerekben a CTAB cmc értékének meghatározása konduktometriás módszerrel $\left(\mathrm{c}_{\mathrm{HyA}}\right.$, kezdeti $\left.=0,1 \mathrm{mg} / \mathrm{mL}\right)$ .72

32. ábra: Az ITC mérésekből nyert kalorimetriás entalpia görbék (A) $5 \mathrm{mM}$ és (B) $12 \mathrm{mM}$ koncentrációjú CTAB titráló oldatok mellett $\left(\mathrm{T}=25^{\circ} \mathrm{C}, \mathrm{c}_{\mathrm{HyA}, \mathrm{kezdeti}}=0,1 \mathrm{mg} / \mathrm{mL}\right)$ (a HyA nélküli mérést a kék vonal jelzi).

33. ábra: M-HyA látszólagos viszkozitási görbéje állandó nyírási sebesség mellett ( $\mathrm{c}_{\mathrm{HyA}}$, kezdeti= $0,1 \mathrm{mg} / \mathrm{mL}, \mathrm{c}_{\mathrm{CTAB}}$, titráló oldat $=25 \mathrm{mM}$ )

34. ábra: M-HyA/CTAB rendszer $(\mathbf{A}) \zeta$ - potenciál, $(\mathbf{B})$ turbiditás és hidrodinamikai átmérő

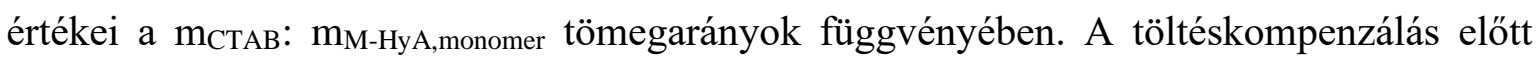
$\left(\mathrm{m}_{\mathrm{CTAB}} / \mathrm{m}_{\mathrm{HyA}, \mathrm{monomer}}=0,2\right)$ és után $\left(\mathrm{m}_{\mathrm{CTAB}} / \mathrm{m}_{\mathrm{HyA}}\right.$,monomer $\left.=0,95\right)$ készített minták reprezentatív fotói (B) $\left(\mathrm{c}_{\mathrm{HyA}}=0,2 \mathrm{mg} / \mathrm{mL}, \mathrm{c}_{\mathrm{CTAB}}=0,0-0,26 \mathrm{mg} / \mathrm{mL}\right.$, PBS közeg) .74

35. ábra: (A) Alacsony koncentrációjú (0,05-1,0 $\mathrm{mg} / \mathrm{mL})$ M-HyA oldatok nyírófeszültségének és (B) a nagyobb koncentrációjú (2-50 mg/mL) oldatok/gélek viszkozitásának változása a nyírósebesség függvényében .76

36. ábra: M-HyA hidrogélek (A) nyírási deformáció és (B) koncentráció függvényében meghatározott viszkoelasztikus paraméterei (A: tárolási modulus ( $\left.G^{\prime}\right)$, veszteségi modulus (G”); B: folyási pont, illetve fáziseltolódás a kezdeti G’ és G” értékek alapján) .77 37. ábra: CTAB -dal neutralizált M-HyA gélek amplitúdó sepréses oszcillációs módszerrel meghatározott reológiai paraméterei (A: kezdeti tárolási (G’) és veszteségi (G”) modulus; B: folyási pont és fáziseltolódás) ( $\left.\mathrm{c}_{\mathrm{HyA}}=50 \mathrm{mg} / \mathrm{mL}\right)$ .78

38. ábra: Térhálósított HyA gélek amplitúdó sepréses oszcillációs módszerrel meghatározott reológiai paraméterei (A: kezdeti tárolási (G’) és veszteségi (G”) modulus; B: folyási pont és fáziseltolódás). .79

39. ábra: (A) A KP-tartalmú térhálósított- és (B) CTAB -dal neutralizált M-HyA hordozókból a KP kioldódási görbéi (pontokkal) és a mérési pontokra Weibull kinetikai 
modellel illesztett görbék (szaggatott vonal) $\left(\mathrm{T}=25^{\circ} \mathrm{C}, \mathrm{pH}=7,4,0,9 \mathrm{w} / \mathrm{w} \% \mathrm{NaCl}, \mathrm{PBS}\right.$ közeg)

40. ábra: (A) A M-Chit-nal titrált H-HyA áramlási potenciál görbéi különböző ecetsavas közegben ( $\left.V_{\text {HyA,titrálandó }}=10 \mathrm{~mL}, c_{\text {HyA,titrálandó }}=0,045 \mathrm{mg} / \mathrm{mL}, c_{C h i t}=0,091 \mathrm{mg} / \mathrm{mL}\right)$ és $(\mathbf{B})$ a poliszacharidok koncentrációeloszlás görbéi $\left(\mathrm{c}_{\mathrm{HyA}}=0,040 \mathrm{mg} / \mathrm{mL}, \mathrm{c}_{\mathrm{Chit}}=9,0 \mu \mathrm{g} / \mathrm{mL}\right) . \mathrm{Az}$ eloszlás görbéken szereplő szimbólumok az adott ecetsavas közeg pH értékét mutatják (•: 2,00 V/V\%; $\mathbf{~ : ~ 1 , 0 0 ~ V / V \% ; ~ : ~ 0 , 7 2 7 ~ V / V \% ; ~} \mathbf{\Delta}: 0,500 \mathrm{~V} / \mathrm{V} \%$ ).

41. ábra: (A) A M-Chit - H-HyA rendszer látszólagos viszkozitásának változása a n $\mathrm{n}_{\text {Chit }} / \mathrm{n}_{\mathrm{HyA}}$ monomer arány és az ecetsav koncentráció függvényében $\left(\mathrm{V}_{\mathrm{HyA} \text {,titrálandó }}=19 \mathrm{~mL}\right.$, $\left.\mathrm{c}_{\text {HyA,titrálandó }}=0,1 \mathrm{mg} / \mathrm{mL}, \mathrm{c}_{\text {Chit,titráló }}=2 \mathrm{mg} / \mathrm{mL}\right)$ és $(\mathbf{B})$ a H-HyA áramlási potenciáljának változása $\mathrm{pH} \approx 4,5$ ecetsav-acetát pufferes közegben $(\mathrm{H}-\mathrm{HyA}: \mathrm{c}=0,045 \mathrm{mg} / \mathrm{mL}, \mathrm{M}-\mathrm{Chit}$ : $\mathrm{c}=$ $0,091 \mathrm{mg} / \mathrm{mL}$ )

42. ábra: A M-Chit, a H-HyA és a különböző tömegarányok mellett készített és liofilizált H-HyA/M-Chit komplexek FT-IR spektrumainak megfelelő részletei ( $\mathrm{V}_{\text {össz }}=10 \mathrm{~mL}$, $\left.\mathrm{c}_{\text {HyA,törzs }}=2 \mathrm{mg} / \mathrm{mL}, \mathrm{c}_{\text {Chit,törzs }}=2 \mathrm{mg} / \mathrm{mL}, \mathrm{c}_{\text {ecetsav }}=1(\mathrm{v} / \mathrm{v}) \%\right)$

43. ábra: A HyA, Chit és a különböző tömegarányok mellett elkészített és liofilizált HyAChit komplexek (A) TG, (B) DTG és (C) DSC görbéi ( $\mathrm{V}_{\text {össz }}=10 \mathrm{~mL}, \mathrm{c}_{\mathrm{HyA} \text {,törzs }}=2 \mathrm{mg} / \mathrm{mL}$, $\left.\mathrm{c}_{\text {Chit,törzs }}=2 \mathrm{mg} / \mathrm{mL}, \mathrm{c}_{\text {ecetsav }}=1(\mathrm{v} / \mathrm{v}) \%\right)$.

44. ábra: A három különböző típusú Chit/HyA hordozó előállításának és a lehetségesen képződő részecskék szerkezetének sematikus ábrázolása

45. ábra: (A) Chit/HyA I. ( $\mathrm{m}_{\text {Chit }} / \mathrm{m}_{\mathrm{HyA}}=0,125-1,00: \mathrm{c}_{\mathrm{Chit}}=0,091 \mathrm{mg} / \mathrm{mL}$, $\mathrm{V}_{\text {Chit }}=0,5-4,0 \mathrm{~mL}$, $\mathrm{c}_{\mathrm{HyA}}=0,042 \mathrm{mg} / \mathrm{mL}, \mathrm{V}_{\mathrm{HyA}}=8,72 \mathrm{~mL} ; \mathrm{m}_{\text {Chit }} / \mathrm{m}_{\mathrm{HyA}}=4-80: \mathrm{c}_{\text {Chit }}=0,364 \mathrm{mg} / \mathrm{mL}, \mathrm{V}_{\text {Chit }}=4,0 \mathrm{~mL}$, $\mathrm{c}_{\mathrm{HyA}}=0,134-0,0067 \mathrm{mg} / \mathrm{mL}, \mathrm{V}_{\mathrm{HyA}}=2,72 \mathrm{~mL}$; HyA: Milli-Q vizes közeg, Chit: $\mathrm{pH} \approx 4,5$ ), illetve (B) Chit/HyA II. és III. részecskék hidrodinamikai átméröjének változása a Chit:HyA tömegarány függvényében ( $\mathrm{c}_{\mathrm{Chit}}=0,30 \mathrm{mg} / \mathrm{mL}, \mathrm{c}_{\mathrm{TPP}}=0,15 \mathrm{mg} / \mathrm{mL}, \mathrm{c}_{\mathrm{HyA}}=3,9-31 \mu \mathrm{g} / \mathrm{mL}$; Chit/HyA II: $\mathrm{V}_{\ddot{\text { össz }}}=4,73 \mathrm{~mL}$, Chit/HyA III: $\mathrm{V}_{\text {össz }}=4 \mathrm{~mL}$ ).

M46. ábra: Hatóanyag nélküli és hatóanyag-tartalmú (A) PLGA65, (B) PLGA75 és (C) PLA méreteloszlási görbéi (szerves fázis: $\mathrm{CPLA}_{\mathrm{PLGA}}=10 \mathrm{mg} / \mathrm{mL}, \mathrm{V}=1,5 \mathrm{~mL}$; vizes fázis: $\mathrm{C}_{\text {PLUR }}=0,1 \mathrm{mg} / \mathrm{mL}, \mathrm{V}=15 \mathrm{~mL}$; matóanyag $=7,5 \mathrm{mg}$ ) 106

M47. ábra: (A) D- $\alpha$-tokoferol-polietilén-glikol-1000-szukcinát, (B) ketoprofen és (C) ( \pm )$\alpha$-tokoferol hatóanyagok UV-Vis spektrofotometriás módszerrel meghatározott kalibrációs spektrumai nagytisztaságú Milli-Q vizes közegben és a hozzájuk tartozó kalibrációs egyenesek. 
M48. ábra: (A) TP-nélküli és (B) TP-tartalmú PLGA65 részecskék FT-IR spektrumai (szerves fázis: $\mathrm{c}_{\mathrm{PLA}}=10 \mathrm{mg} / \mathrm{mL}, \mathrm{c}_{\mathrm{TP}}=2,5 \mathrm{mg} / \mathrm{mL}$; vizes fázis: $\mathrm{c}_{\mathrm{PLUR}}=0,1 \mathrm{mg} / \mathrm{mL}$ ) 108

M49. ábra: A TP UV spektrumai és a meghatározott kalibrációs egyenes PBS közegben $\left(\mathrm{pH}=7,4 ; 0,9 \% \mathrm{NaCl} ; \mathrm{C}_{\text {PLUR }}=1 \mathrm{mg} / \mathrm{mL}\right)$. 108

M50. ábra: A KP UV-Vis spetrofotometriás módszerrel meghatározott kalibrációs egyenese PBS közegben $\left(\mathrm{pH}=7,4 ; 0,9 \% \mathrm{NaCl}, \lambda_{\max }=260 \mathrm{~nm}\right)$. 108

1. táblázat: A PLA alapú, TP-tartalmú kolloid részecskék előállításához használt komponensek koncentráció és térfogat adatai

2. táblázat: A DSC és a DLS mérésekkel meghatározott üvegesedési hőmérséklet $\left(\mathrm{T}_{\mathrm{g}, \max }\right)$, degradációs hőmérséklet $\left(\mathrm{T}_{\mathrm{d}, \max }\right)$, átlagos molekulatömeg és második viriál együttható értékek a szintetizált, illetve a kereskedelmi forgalomban kapható PLA/PLGA esetén ..... 47 3. táblázat: Nanoprecipitációs eljárással előállított PLA/PLGA részecskék DLS módszerrel meghatározott hidrodinamikai átmérő ( $\left.\mathrm{d}_{\mathrm{DLS}}\right)$ és polidiszperzitási index (PI) értékei. 50

4. táblázat: A PLUR -stabilizált hatóanyag-tartalmú PLA /PLGA részecskék átlagos részecske átmérői, a polidiszperzitási indexek és a kapszulázási hatékonyságok.

5. táblázat: Nanoprecipitációval előállított TP-tartalmú PLA részecskék átlagos részecske átmérő értékei, a polidiszperzitási indexek (PI), valamint a EE(\%) és DL(\%) értékek az alkalmazott kezdeti koncentrációk esetében 56

6. táblázat: A szakirodalomban jelenleg megtalálható, különböző módszerekkel előállított TP-tartalmú polimer alapú hordozó részecskék átlagos méretei, a ל-potenciál, az EE(\%) és DL(\%) értékek a forrásközlemények megjelölésével.

7. táblázat: PLGA50 alapú TP-nélküli és TP-tartalmú folyamatos áramlásos technikával előállított részecskék DLS módszerrel meghatározott hidrodinamikai átmérője és polidiszperzitási index értékei különböző áramlási paraméterek függvényében 61

8. táblázat: $\mathrm{A} T \mathrm{TP}$-tartalmú PLA/PLGA alapú hordozó rendszerek kioldódási görbéire illesztett kinetikai modellek (12-14. egyenlet) megfelelő paraméterei 67

9. táblázat: A különböző koncentrációjú M-HyA/CTAB oldatok viszkozitás és nyírófeszültség görbéire illesztett Bingham és Carreau-Yasuda modellekböl meghatározott plasztikus viszkozitás $\left(\eta_{\mathrm{pl}}\right)$, Bingham-féle folyáshatár $\left(\tau_{\mathrm{B}}\right)$, nulla- nyírási viszkozitás $\left(\eta_{0}\right)$ és végtelen-nyírási viszkozitás $\left(\eta_{\infty}\right)$ értékek .76

10. táblázat: A KP-tartalmú térhálósított és $\mathrm{CTAB}$-dal neutralizált M-HyA rendszerek kioldódási görbéire illesztett kinetikai modellek (12-14. egyenlet) megfelelő paraméterei81 


\section{Bevezetés}

Széleskörü felhasználhatóságuknak köszönhetően a nanoszerkezetü anyagok tanulmányozása a modernkori kolloidkémia egyik dinamikusan fejlődő kutatási területévé vált. A nanoszerkezetű anyagok közül is egyre nagyobb teret hódítanak a különböző hatóanyag-szállító rendszerek, mivel alkalmazásukkal meghosszabbíthatjuk és fokozhatjuk egyes gyógyszerek hatékonyságát, továbbá lehetőség nyílik olyan terápiás vegyületek szervezetbe vitelére is, amelyek célzott helyre juttatását jelentősen nehezíti az adott hatóanyag specifikus tulajdonsága (pl.: hidrofilitás, töltés, degradáció). A nanoszerkezetű anyagok hordozóként való alkalmazhatóságának feltétele, hogy nagymértékủ stabilitással rendelkezzenek, illetve méretük a 100-200 nm tartományt ne haladja meg. Számos szervetlen és szerves alapú hatóanyag szállító nanorészecske ismert. Ezek közül kiemelkedő szerepet töltenek be a különböző polimerek, melyet megerősít a polimer alapú hordozó nanorészecskék témakörében megjelent publikációk számának évről évre történő rohamos emelkedése is (1. ábra).

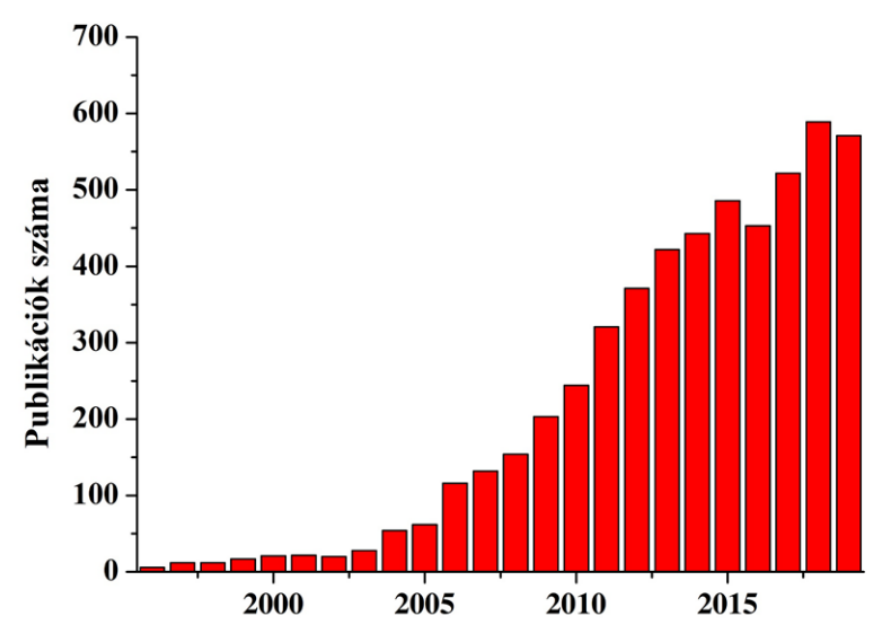

1. ábra: A „polimer alapú hordozó nanorészecskék” témában megjelent publikációk számának változása 1996-2019 között 5281db publikáció alapján ${ }^{1}$

A polimerek hatalmas családján belül, biokompatibilitásuk és könnyü kezelhetőségük eredményeként, kitüntetett szerep jut az un. biopolimereknek (pl: polikaprolakton (PCL), poli(tejsav) (PLA), poli(laktid-ko-glikolid) (PLGA)) és poliszacharidoknak (pl: hialuronsav, kitozán) főként orvosbiológiai és nanomedicina területeken (gyógyszer)hatóanyag hordozóként történő lehetséges alkalmazásuk következtében. A

\footnotetext{
${ }^{1}$ A publikációk számának eloszlását a Clarivate Analytics Web of Science tudománymetriai adatbázis segítségével a ,polymer carrier nanoparticle” kifejezés esetében határoztuk meg.
} 
biopolimerek/poliszacharidok szerkezeti módosítása (kopolimerizáció, neutralizáció, keresztkötés stb.) révén szisztematikusan változtathatjuk hidrofilitási tulajdonságukat, ami megkönnyítheti a hatóanyagok polimer részecskébe való juttatását. A biopolimer/poliszacharid alapú részecskék szintézisére szolgáló technikák széles választékának köszönhetően, figyelembe véve a felhasználási területet és a gyógyszer vegyületek tulajdonságát, napjainkban már különböző, a hatóanyagokra formált hordozó részecskéket állíthatunk elő, amelyek szerkezetét és kapszulázási hatékonyságát a szintézisek során beállított paraméterek változtatásával optimalizálni tudjuk.

A nanoszerkezetü hatóanyag hordozó rendszerekkel kapcsolatos kutatások mind hazai, mind nemzetközi szinten egyre nagyobb jelentőséggel bírnak. Mindezeket figyelembe véve doktori munkám legfőbb célja volt, hogy kutatási eredményeinkkel átfogó információt nyújtsunk néhány biopolimer/poliszacharid alapú nanoszerkezetü hatóanyag szállító rendszer reproduktív módon történő előállítását befolyásoló tényezőjéről, melyek döntő hatással bírnak az előállított hatóanyag hordozó kolloid részecskék méretére, szerkezetére, összetételére, a kapszulázási hatékonyságra és a hatóanyag szabályozott úton történő leadására vonatkozóan. 


\section{Irodalmi áttekintés}

\subsection{Kolloid részecskék, mint gyógyszerhatóanyag hordozók}

Akár kisebb megfázás kezelésére alkalmazott gyógyszerről, akár súlyosabb daganatos megbetegedésnél felhasznált terápiás szerekröl beszélünk, a gyógyszerszármazékok szervezetbe vitelére mindig is kitüntetett figyelem fordult. A hétköznapi életben leggyakrabban különböző tabletta, kapszula, injekció/csepp vagy kenőcs alapú „klasszikus” gyógyszer formulákkal találkozhatunk, melyek előállítása és gyártása a modernkori gyógyszeriparban viszonylag könnyen kivitelezhető. Fontos kiemelni, hogy a hatóanyagok ilyen formában való alkalmazásakor esetenként csak rövidtávú és kontrol nélküli felszabadulás érhető el, ami az egyes betegségek kezelésénél csak sürübb adagolással és magasabb dózissal korrigálható időnként súlyos mellékhatásokat eredményezve. A gyógyszerszármazékok elnyújtott hasznosulásának és célzott helyre juttatásának érdekében a 21. századi gyógyszeripari kutatások egyik fó ágát képezi új típusú mikro- és nanoszerkezetü hatóanyag hordozó rendszerek tervezése és fejlesztése. Ennek legfőbb oka, hogy a gyógyszerszármazékok „kapszulázása” révén késleltetett, szabályozott és lokalizált hatóanyagleadást érhetünk el. Hatóanyag hordozó részecskék esetében akkor beszélhetünk nanométeres mérettartományról, ha azok mérete az 1-100 nm tartományban van [1]. Ettől eltérően, a szervezetben lévő mikrokapillárisok átlagos átmérőjének megfelelően a nanorészecskék orvosbiológiai felhasználhatósága már $200 \mathrm{~nm}$ alatti átméröknél is megvalósítható [2]. A részecskék hatékonysága és célzott helyre juttatása szerkezetük (pl. alak, felület) és az összetételük módosításával befolyásolható és javítható [3], ami a hagyományos gyógyszer kapszulázási módszerekhez képest nagy előnyt jelent.

A liposzómális hordozórendszerek megismerésétől kezdve napjainkig számos, már kereskedelemben is kapható (pl. a doxorubicin-tartalmú liposzómális Doxil [4], a fehérje alapú Abraxane [5], a polimer alapú Genexol- PM [6]) és számos klinikai fejlesztés és tesztelés alatt álló (pl. rákos daganatok elleni antitestet tartalmazó (Anti-EGFR: anti epidermális növekedési faktor receptor) liposzómák [7], felkonvertáló nanorészecskék (UCNPs) fotodinamikai terápiára (PDT)[8])) hatóanyag-tartalmú termék ismert, ahogyan azt a 2. ábra is összefoglalja. Mindezek megerősítik, hogy korszerü, új típusú hordozó rendszerek fejlesztésére irányuló kutatásokra folyamatos igény van.

Napjainkban a hatóanyag hordozókat a fehérjéktől kezdve az agyagásványokig sokféle anyagtípusból előállíthatjuk. Ennek rendszerezése érdekében a hordozókat döntően három fő csoportba sorolhatjuk: szervetlen, szerves (pl. liposzóma, szilárd lipid, dendrimerek, 
micellák, polimer) és hibrid (pl. fehérje-polimer hibrid, kerámia-polimer hibrid) rendszerek (3. ábra).

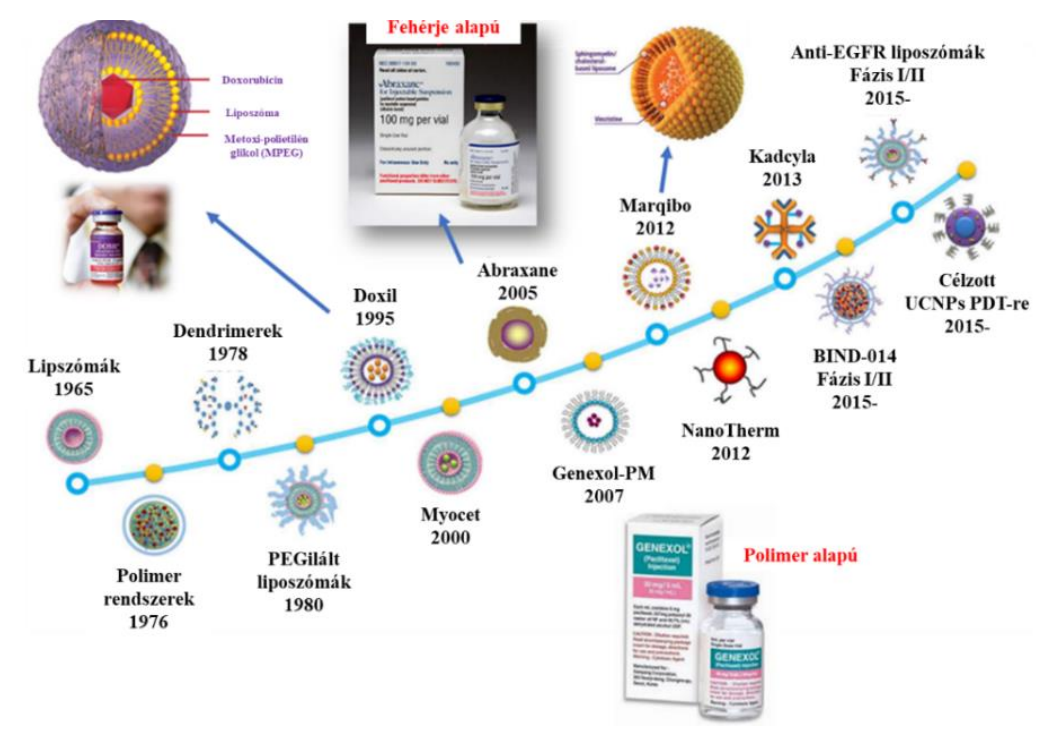

2. ábra: A nanoszerkezetü hatóanyag hordozót-tartalmazó termékek fejlődése a liposzómális hordozórendszerek megismerésétől napjainkig [9]

Szervetlen hordozóként széles körben alkalmaznak különböző arany [10,11], mágneses [12], mezopórusos szilika [13] mikro-, illetve nanorészecskéket vagy éppen réteges szerkezetű agyagásvány (pl. réteges kettős hidroxidok (layered double hydroxide: LDH)) nanoszerkezeteket stb. [14]. A szervetlen alapú rendszerek előnye, hogy a méret és a szerkezet változtatásával a részecskék mágneses és optikai tulajdonságai szabályozhatóak, így a hatóanyag szállításán kívül a képalkotásban, sejtek jelölésben vagy diagnosztikában egyaránt kiemelkedő szerepet tölthetnek be [15].

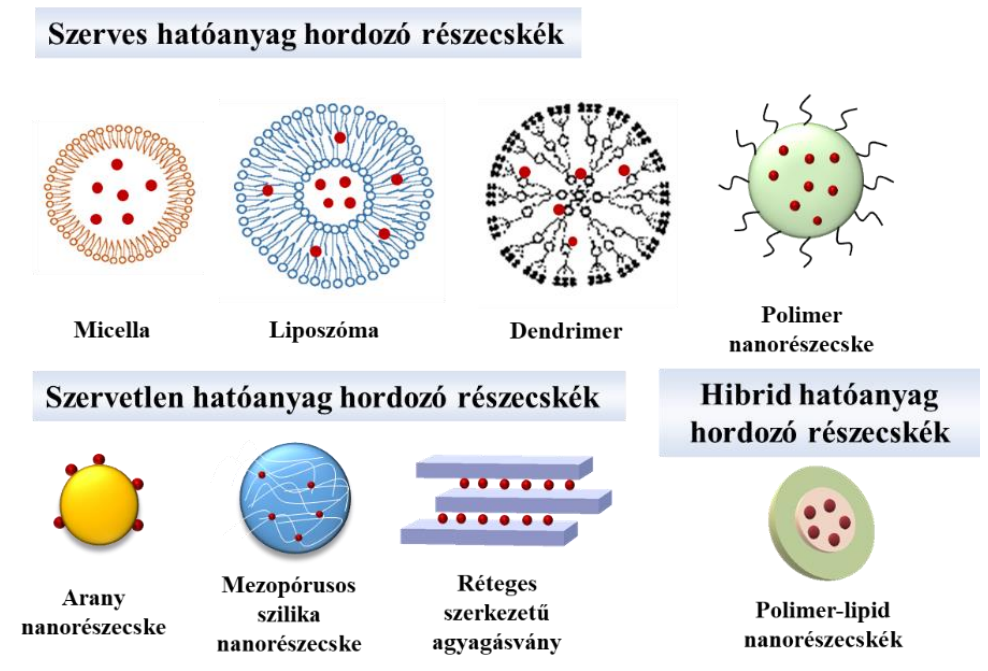

3. ábra: Hatóanyag hordozóként alkalmazható rendszerek sematikus ábrái 
Kutatócsoportunk korábbi munkájában mezopórusos szilika alapú hordozókat állítottak elő és alkalmazták azokat eredményesen nem-szteroid gyulladáscsökkentő ibuprofen (IBU) kapszulázására [16]. A hatóanyag visszatartás növelése érdekében, a kolloidális részecskéken $(\mathrm{d} \sim 400 \mathrm{~nm})$ sikeresen alakítottak ki többrétegü héjként polietilénimin (PEI) és nátrium-polisztirol-szulfonát (PSS) polimer rétegeket és a hatóanyag felszabadulást tanulmányozták a kialakított héjak függvényében. A szilika részecskék mellett 2017-ben a Kutatócsoportunk Deák Ágota munkája révén sikeresen szintetizált $\mathrm{Mg} / \mathrm{Al}$ réteges kettős hidroxidot $(\mathrm{Mg} / \mathrm{Al} \mathrm{LDH})$, melynek szerkezetét széleskörüen jellemezte (fajlagos felület $114,96 \pm 0,48 \mathrm{~m}^{2} / \mathrm{g}$, felületi töltés (+0,641 meq/g), lamella távolság $\mathrm{stb}$.), majd neuroaktív hatású kinurénsav (KYNA) interkalálását valósította meg egyszerü ioncserés eljárással. Az előállított LDH/KYNA réteges szerkezű kompozit összetételének, szerkezetének, hatóanyag-tartalmának meghatározása mellett (120 mg KYNA/g LDH) a hatóanyag kioldódását is eredményesen tanulmányozta mesterséges gyomorsav közegben, ugyanis a vizsgált molekula ígéretes hatásokat fejthet ki a gyomorfekély kezelésében. Igazolta, hogy az interkalálás révén a hatóanyag felszabadulása kb. 25-30\%-kal lassabban történik meg, mint ahogy az a hordozó nélkül figyelhető meg vizsgált 6 órás intervallumban [17].

A szervetlen alapú hordozók mellett alacsony toxicitásuknak köszönhetően gyakran alkalmaznak asszociációs kolloidokat, dendrimereket, fehérjéket vagy különféle polimereket hatóanyag szállító kolloid rendszerek alapjául. Ezek előállítására és vizsgálatára irányuló kutatások központi szerepet töltenek be a modernkori nanomedicina területén.

Az asszociációs kolloidokon belül a nioszómális és a liposzómális rendszerek a legelterjedtebbek. A nioszómáknál nem-ionos tenzidekből, míg liposzómáknál foszfolipidekből felépülő unilamellás (egy kettősrétegből felépülő) vagy multilamellás (több kettős rétegből felépülő) vezikulákról beszélünk, melyek mind hidrofil, mind lipofil hatóanyagok szállítására felhasználhatóak [18,19].

A dendrimerek gömb alakú, elágazó láncú makromolekulák, melyek központjában egy magmolekula áll, amihez különböző polimer láncok/terminális aktív csoportok kapcsolódnak. A kiindulási maghoz adott elágazási szintekkel egy több generációs régiókból álló összetett rendszer képződik, ahol az elágazó láncok funkcionalizálhatóak. A hatóanyag az előállítási folyamat megfelelő kiválasztásával a dendrimer mag közelében vagy a felsőbb elágazási szinteken is megkötődhet [20,21].

A szerves hordozók egyik nagy csoportját a fehérje alapú nanorészecskék jelentik [22]. Kutatócsoportunkban korábban sikeresen igazolták, hogy a neuroaktív KYNA vér-agy gáton 
való transzportja marha szérum albumin (BSA) alapú kompozit révén sikeresen megvalósítható [23]. A kutatómunka eredményéből elfogadott magyar ${ }^{2}$ (2015) és nemzetközi (2020) szabadalom is született. Ezen munkához kapcsolódva sikeresen kiviteleztük elsőként az irodalomban a fenti mag-héj szerkezetű részecskék előállítását áramló rendszerben is - ezen munkában már én is tevékenyen részt vettem - ahol a reaktánsok arányának, áramlási sebességének és a nyomásnak a hatását tanulmányoztuk az optimális mag-héj struktúra kialakulásához [24]. Igazoltuk, hogy ezen technikával költséghatékonyan, rövidebb idő alatt és nagyobb mennyiségben is elöállíthatunk a klasszikus preparatív technikához képest 15-20\%-kal kisebb és monodiszperzebb BSA alapú KYNA-tartalmú, vagy ezen hatóanyaghoz hasonló szerkezetủ és oldékonyságú molekulákat tartalmazó kolloid részecskéket. Sikeresen állítottunk elő továbbá mag-héj szerkezetü BSA/hialuronsav (HyA) komplex kolloid részecskéket is, melyek átlagosan 210-240 nm átlagos átmérővel rendelkeznek [25]. Ahogyan a kutatómunkából megjelent közlemény grafikus absztraktja is mutatja a 4. ábra formájában, a kompozit képződése csak adott BSA/HyA tömegarány alkalmazása esetén valósul meg. A kompozit előállításához hozzájárulva az irodalomban elsőként tanulmányoztuk kvantitatívan a nevezett két makromolekula kölcsönhatását számos méréstechnika felhasználásával. Ezen munka eredményei nem képezték doktori értekezésem alapját, így ezeket nem mutatjuk be részletesen.

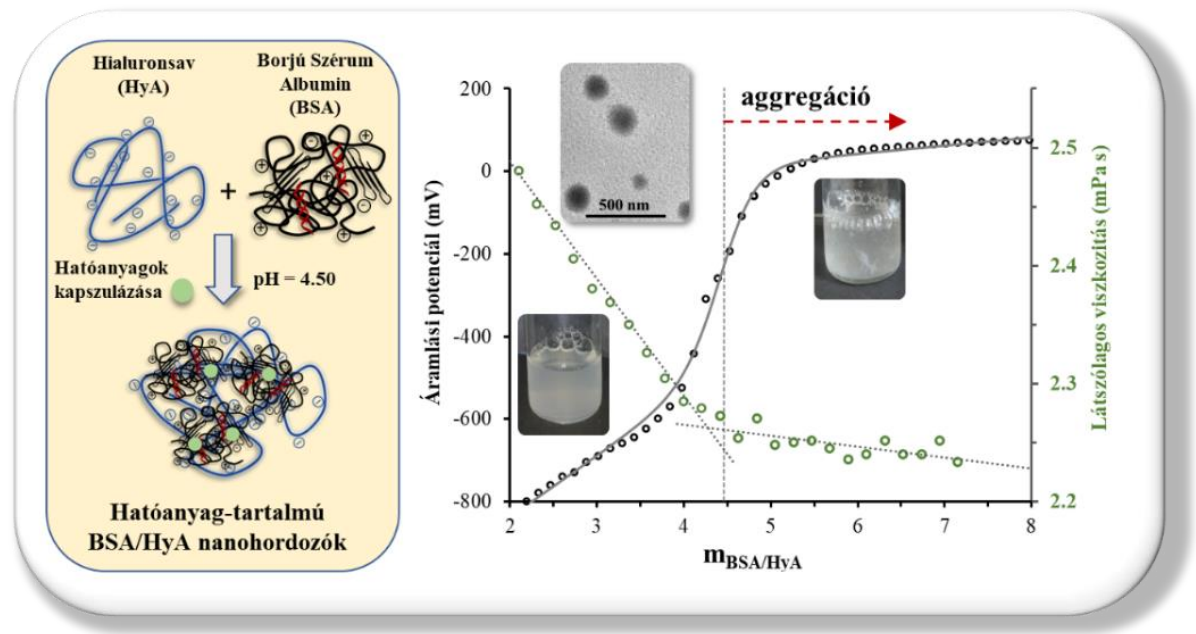

4. ábra: BSA/HyA komplex kolloid részecskék előállításának sematikus ábrája (bal oldal) és a képződő kolloid részecskék szerkezeti tanulmányozásának eredményei az alkalmazott mBSA $/ m_{H y A}$ tömegarány függvényében (jobb oldal) [25]

\footnotetext{
${ }^{2}$ Dékány I., Vécsei L., Varga N., Toldi J., Majláth Zs., Krizbai I., Hatóanyagoknak a központi idegrendszerben történö szabályozott leadására alkalmas nanokompozit, eljárás annak elóállitására és alkalmazása, 2015, Bejelentés ügyszáma: P1500356
} 
A disszertációm alapját képező polimer alapú hordozó rendszereket a következő alfejezetekben mutatom be részletesen.

\subsection{Makromolekulás (polimer alapú) hatóanyag hordozók}

\subsubsection{Polimer alapú nanorészecskék jellemzése}

A hatóanyagok kapszulázására felhasználható hordozók egyik nagy családját a polimer alapú részecskék alkotják, melyek előállítására biokompatibilis és nem toxikus makromolekulákat használnak. Ilyen makromolekulák lehetnek természetes eredetűek (úgymint a kitozán, alginát, zselatin stb.) vagy szintetikusan előállított származékok (pl. poli(tejsav), polikaprolakton, polietilén-glikol (PEG), poli( $N$-izopropil-akrilamid) (PNIPAM)) [1,26-28]. Felhasználásuk legfontosabb feltétele, hogy a szervezetbe juttatáskor és a hatóanyag felszabadulásakor lejátszódó polimer degradáció olyan monomer végterméke(ke)t eredményezzen, melyet a humán szervezetben lejátszódó anyagcsere folyamatok le tudnak bontani [29]. A polimer alapú hordozóknál a hatóanyag egyaránt elhelyezkedhet a részecskék felületén, a részecskékben egyenletesen eloszlatva vagy egy központi magban csoportosulva. Ennek függvényében a részecskék szerkezete alapján megkülönböztethetünk nanokapszulákat és nanogömböket. Nanokapszuláknál a hatóanyag magokat egy polimer héj borítja, míg a nanogömböknél a hatóanyag a polimer mátrixban homogénen oszlik el [27]. Ezeknek a struktúráknak a kialakulását a részecskék előállításához használt módszerekkel és a kezdeti paraméterekkel szabályozhatjuk.

Kiváló biokompatibilitásuknak köszönhetően a polimer részecskéket egyaránt alkalmazzák rákellenes vegyületek [30], vakcinák [31], vitaminok [32] vagy fogamzásgátló hormonok [33] kapszulázására. A rákellenes hatóanyagként alkalmazható doxorubicin polimer hordozókba (pl. doxorubicin-PLGA konjugátum, kitozán (Chit)) kapszulázásával kapcsolatban számos publikáció megtalálható a szakirodalom [34-38], mivel lipofil tulajdonsága miatt közvetlen alkalmazása korlátozott. A polimer alapú nanorészecskék jól beilleszthetőek, egyéb orvosbiológiai irányú gyógyszerfelszabadulással kapcsolatos kutatásba, úgymint a szövettechnikában $[39,40]$, mivel a hordozókba kapszulázott gének és hatóanyagok serkenthetik a szövetek növekedését és a beépülését a szervezetbe. Napjainkban a kutatók egyre nagyobb figyelmet fordítanak a különböző ingerre érzékeny (pl. pH, hőmérséklet) polimer hibrid (smart) részecskék előállítására [41]. A pH változására érzékeny nanorészecskéknél előszeretettel alkalmaznak PEG bevonatokat [42]. Ebben az esetben a pH csökkenésekor a védő polimer réteg leválik a részecskék felületéről, mellyel csökken vagy teljesen megszünik a hatóanyag visszatartó hatás. 


\subsubsection{Polimer alapú nanorészecskék elöállitási lehetöségei}

A makromolekuláris kolloidokból felépülő nanorészecskék előállítására a szakirodalomban már számos technikát olvashatunk. A módszerek csoportosítása szerint a részecskéket előállíthatjuk monomeregységekből polimerizációval vagy polireakciókkal, illetve már kereskedelmi forgalomban kapható szintetizált polimerekből kiindulva. Monomeregységekből leggyakrabban (mini-, mikro-, stabilizátor nélküli) emulziós és un. határfelületen lejátszódó polimerizációval képeznek nanorészecskéket [43], míg kész, már rendelkezésre álló polimereknél az emulziós, nanoprecipitációs, gélesedési, „kisózásos”, dialízis, és szuperkritikus technikák az elterjedtek, melyeket az 5. ábra foglal össze $[44,45]$. Doktori disszertációm során a nanorészecskék előállításához főként a laboratóriumunkban szintetizált és néhány a kereskedelmi forgalomban kapható makromolekulákat alkalmaztuk, így a továbbiakban az utóbb említett technikákat mutatjuk be részletesen.

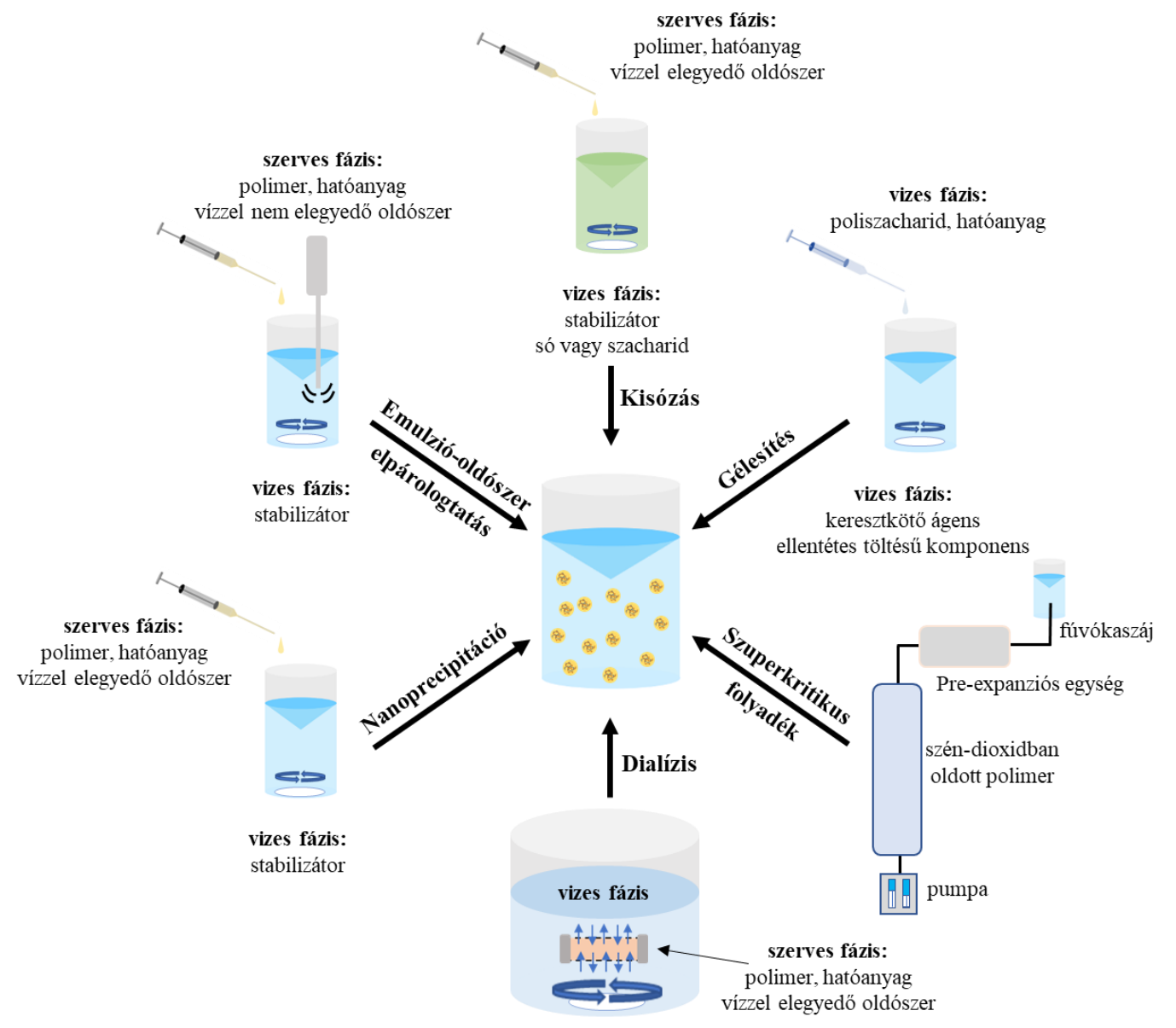

5. ábra: Polimer alapú hordozó rendszerek előállítási lehetőségei makromolekulákból

A polimer alapú nanorészecskék előállítására kidolgozott első technika az emulziósoldószer elpárologtatásos eljárás volt [46]. A módszernél főként olaj a vízben $(\mathrm{O} / \mathrm{V})$ 
emulziós rendszert használnak, ahol a polimereket vízzel nem elegyedő illékony oldószerben, leggyakrabban diklórmetánban, kloroformban, vagy etil-acetátban, oldják, majd az oldatot vizes közegben diszpergálják. Az emulziók kialakításához nagy fordulatszámú kevertetés és/vagy ultrahangos szonikálás szükséges [47], illetve a rendszer stabilitásának megtartásához a vizes közegben különböző stabilizátort alkalmaznak (pl. polivinil-alkohol (PVA), kationos vagy anionos felületaktív anyag stb.) [48]. Az emulziós cseppeket alkotó szerves oldószer elpárolgásának következtében egy polimer alapú nanorészecske szuszpenzió képződik.

Az oldószer elpárologtatásos technikát felhasználva víz/olaj/víz (V/O/V) duplaemulziós rendszerek is előállíthatóak, ahol az emulziós csepp belső vizes fázisú magjában hidrofil tulajdonságú gyógyszerszármazékok kapszulázása is megvalósítható [49,50]. Ennek az eljárásnak az alapja, hogy a hatóanyag-tartalmú vizes fázisból és a polimer-tartalmú szerves fázisból egy víz/olaj (V/O) emulziót készítenek, amit egy stabilizátort tartalmazó vizes fázisban (V/O/V) emulgeálnak. A szerves oldószer elpárologtatásával hidrofil hatóanyagot tartalmazó polimer nanorészecskék képződnek. Az emulziós módszerek hátránya, hogy a felhasznált szerves oldószerek mind a környezetre, mind az élő szervezetre káros hatással vannak.

Az emulziós eljárás egyik módosított formája az un. „kisózáson” alapuló technika, ahol egy, a vízzel jól elegyedő szerves oldószert felhasználva $\mathrm{O} / \mathrm{V}$ emulzió állítható elő vizes fázisban lévő elektrolitok segítségével [51]. Ilyen sóként gyakran alkalmaznak pl. magnézium-kloridot vagy kalcium-kloridot. A kialakuló emulziós rendszerhez vizet adagolva a só koncentráció csökken és a szerves oldószer kiáramlik a vizes közegbe. Ennek következtében az emulziós cseppekben lévő polimer precipitálódik és részecskéket képez.

A kutatómunkánk során is használt nanoprecipitációs módszer a polimer alapú hordozó rendszerek előállítására egy könnyen kivitelezhető technika. Az eljárást elsőként $H$. Fessi és munkatársai alkalmazták nem-szteroid gyulladáscsökkentő (nonsteroidal antiinflammatory drug: NSAID) indometacin-tartalmú PLA nanokapszulák preparálásához [52]. A nanoprecipitáció, más néven oldószer kiszorításos, technikánál a vizsgálni kívánt hidrofób polimert és ideális esetben a hatóanyagot egy vízzel jól elegyedő szerves oldószerben feloldják és az elkészített oldatot egy stabilizátor-tartalmú vizes közegbe csepegtetik [44,53,54]. Ahogy a szerves oldószer elpárolog, a polimer kicsapódik a vizes közegben, ami részecskék képződését eredményezi. A polimer nanorészecskék kialakulása az oldószer kicserélésekor a vizes és szerves fázis felületén kialakuló határfelületi turbulenciához köthető $[45,54,55]$. Ennek köszönhetöen a folyamatokat az un. Marangoni effektus 
szabályozza. A vizes fázishoz adagolt polimer-tartalmú szerves fázisról nanoméretü cseppek szakadnak le, amiket a jelenlévő felületaktív anyag addig stabilizál, míg a szerves fázis gyors diffúziója és a polimer kicsapódása le nem játszódik. Szerves oldószerként gyakran alkalmaznak acetont, etanolt, dioxánt, dimetil-szulfoxidot stb., mivel nagyon jól elegyednek vízzel és az emulziós eljáráshoz képest kevésbé toxikusak a környezetre.

A részecskék előállítására jól alkalmazhatóak a dialízis és a szuperkritikus folyadék eljárások is. A dialízis technikánál a polimer oldatot egy megfelelő pórusméretü membránba/dialízis csőbe helyezik, amit egy, a polimer oldat közegével jól elegyedö, oldószerbe (polimer szempontjából kicsapószerbe) helyeznek [56,57]. A dialízis során a membrán belül lévő oldószer kicserélődik és részecskék képződése mellett a polimer kicsapódik. A szuperkritikus folyadékon alapuló módszerek közül a gyors expanziós eljárások (RESS: rapid expansion of supercritical solution, RESOLV: rapid expansion of supercritical solution into liquid solvent) a legelterjedtebbek $[43,58]$. A folyamatok során a makromolekulákat szuperkritikus folyadékban, főleg szén-dioxidban, feloldják és egy kapilláris fúvókán keresztül levegőbe (RESS) vagy folyadékba (RESOLV) kiengedik, ahol az oldat kitágul. A hirtelen nyomáscsökkenéssel a polimerrel túltelített rendszerben részecskék képződnek.

Az előzőleg említett módszerek hátránya, hogy főleg hidrofób polimer nanorészecskék előállítására alkalmazhatóak, ezért a hidrofil polimereknél más technikák felhasználása szükséges. A hidrofil tulajdonságú poliszacharidokból (pl. hialuronsav, kitozán) elsőrendü vagy gyengébb másodrendü kölcsönhatásokon alapuló gélesedési módszerekkel lehet részecskéket készíteni [59]. A kémiai térhálósításon alapuló gélesítési technikánál a poliszacharid láncok között kovalens kötéssel keresztkötő ágenseket (pl. hialuronsav diaminnal történő keresztkötése [60]) rögzítenek. A kialakuló keresztkötött poliszacharid gombolyagokból megfelelő kezdeti paraméterek mellett nanorészecskék állíthatóak elő. A módszer hátránya, hogy a szintéziskor használt reagensek toxikusak lehetnek, így a felhasználásuk előtt a részecskéket mindig tisztítani kell. Az ionos gélesedési módszerek közül a polielektrolittal történő komplexképződésnél ezzel ellentétben nincs szükség reagensre a reverzibilis kölcsönhatások kialakítására. Ebben az esetben a felhasznált poliszacharidot a töltésének megfelelően semleges vagy enyhén savas közegben oldják, majd egy ellentétes töltésű komponenst (pl. felületaktív anyagot, ellentétes töltésü polimert/polielektrolitot) tartalmazó oldatba csepegtetik (5. ábra). A töltés kompenzálása során kialakuló komplex rendszerek nanorészecskék formájában kicsapódnak az oldatokban. 


\subsubsection{Polimer nanorészecskék elöállitása folyamatos áramú, áramlásos kémiai} mikroreaktorban

Az előző alfejezetben említett hagyományos és gyakorta alkalmazott polimer nanorészecske előállítási technikák nagyobb mintamennyiségek preparálására kevésbé alkalmasak, illetve költséghatékonyságukat nézve nem kifizetődőek. Ennek kiküszöbölésére az 1990-es évektől kezdve egyre elterjedtebben alkalmaznak különböző folyamatos áramú, áramlásos kémiai rendszereket [61], melyek felhasználásával könnyen szabályozható, reprodukálható és jól követhető elöállítási módszerek fejleszthetőek [62]. Az áramlási sebességek, a hőmérséklet, nyomás és egyéb fontos paraméter változtatásával a részecskék mérete és polidiszperzitása jelentős mértékben csökkenthető és szabályozható [63].

Az áramlási technikák közül a mikroreaktorokkal kapcsolatos kutatások az elmúlt pár évben a hatóanyag hordozó rendszerekkel kapcsolatos kutatások egy dinamikusan fejlődő ágává nőtte ki magát [62], ahol a mikro- és nanorészecskék előállítása a korábban említett (pl. emulziós, nanoprecipitációs) módszerek áramlásos rendszerbe történő beintegrálásával valósítható meg. A mikroreaktorok felépítése szerint három fő részből épülnek fel: mintaadagoló pumpából, mixer cellából és mintagyüjtő részből (6. ábra).

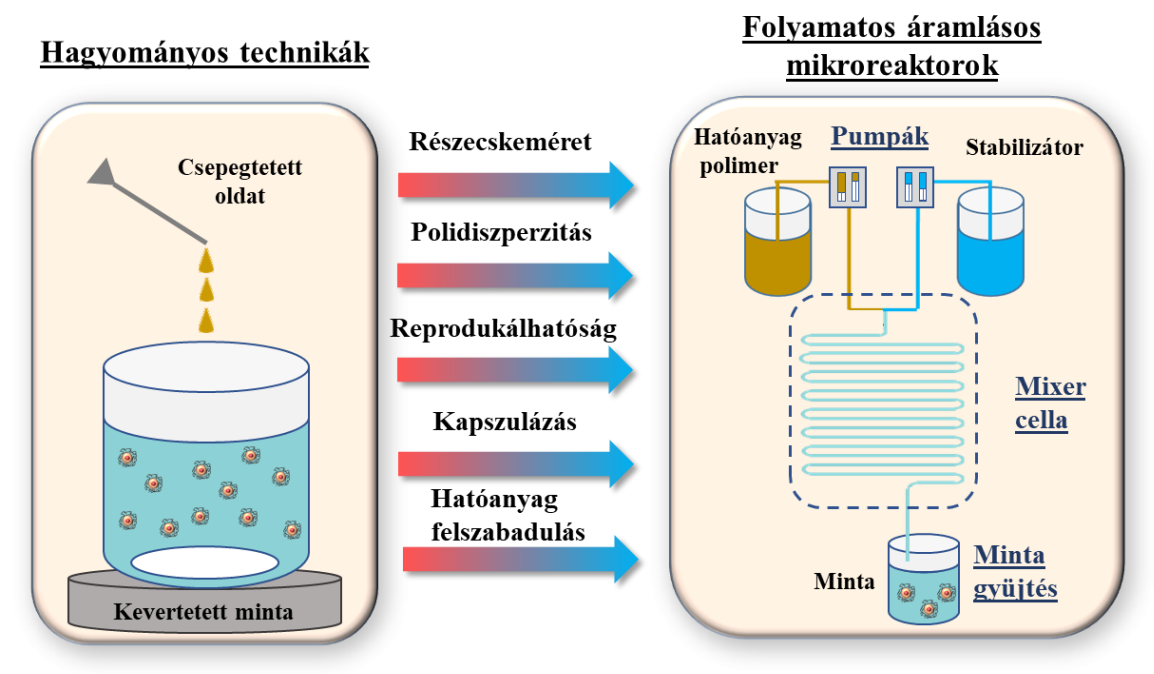

6. ábra: Polimer részecskék előállítására alkalmazott hagyományos technika (bal oldal) és a folyamatos áramlásos mikroreaktor általános sematikus ábrája (jobb oldal)

A pumpák müködésük során folyamatos áramlási sebességet biztosítva adagolják a szükséges mintamennyiséget a rendszerbe. Az alkalmazott mixer cellákat aktív és passzív csoportba sorolhatjuk [64]. Passzív celláknál a turbulens áramlási profil és a minták összekeverése a csatornák geometriájával, míg aktív celláknál külső behatással (pl. 
hőmérséklet, nyomás) érhető el. Az előállítás közegét nézve megkülönböztethetünk egyfázisú (pl. precipitációs rendszerek [65]) és többfázisú (pl. emulziós rendszerek [66]) rendszereket is. A mikroreaktor alapú folyamatos áramlási technikák alkalmazását nehezíti, hogy az optimális paraméterek (pl. áramlási sebesség, áramlási sebesség arányok, kezdeti koncentráció) ismerete nélkül a hatóanyag-tartalmú nanorészecskék előállításakor a kapszulázás nem valósul meg és a cellák könnyen eltömődhetnek, így a kiindulási optimális koncentrációk előkísérletekben történő meghatározása döntő fontosságú.

\subsection{PLA/PLGA és Hialuronsav alapú rendszerek jellemzése}

\subsubsection{PLA/PLGA alapú hatóanyag hordozó rendszerek}

A PLA egy 2-hidroxi propionsav (tejsav) monomer egységekből felépülő, kiváló biokompatibilitással rendelkező alifás poliészter [67]. Biodegradábilis és komposztálható sajátságának köszönhetően az elmúlt évtizedekben az élelmiszer-csomagolás technikától a nanomedicináig minden területen megtalálható [68]. Elsőként Théophile-Jules Pelouze állított elő PLA polimert tejsav polikondenzációs reakciójával [69], míg Wallace Hume Carothes 1932 -ben fejlesztett ki egy olyan módszert, ahol a PLA-t laktidból (tejsav ciklikus dimerje) polimerizációs folyamatokkal állított elő [70]. Ezt később a DuPont amerikai vállalat 1954-ben szabadalmaztatta.

A PLA-t felépítő tejsav monomereket fermentációval (pl. cukornádból [71,72]) vagy kémiai szintézissel (pl. laktonitril erős savas hidrolízise [73]) is előállítható. A kémiai szintézisek hátránya, hogy a folyamatok során a tejsav L(+) és D(-) két sztereoizomerjének racém elegye képződik, míg a fermentációnál a baktériumtörzsek megfelelő kiválasztásával a sztereoizomerek külön is előállíthatóak [74]. A felhasználhatóság szempontjából a PLA amorf és kristályos jellege nagy szerepel bír, mivel stabilitása és termikus sajátsága jelentősen változhat a szerkezete függvényében. M. Pyda és munkatársai korábban már vizsgálták az amorf és a kristályos PLA hőkapacitását és megállapították, hogy a PLA kristályos szerkezete csak 90 \% -nál nagyobb L-tejsav monomeregység mennyiség mellett érhető el [75]. A PLA-ban lévő L- és D- tejsav arányok függvényében a kialakuló kristályszerkezet $\alpha, \beta$ vagy $\gamma$ formát vehet fel, melyek közül a legstabilabb az $\alpha$ forma [76].

A PLA polimer előnye, hogy a kopolimerizáció révén a degradációs, a biokompatibilitási és a hidrofilitási tulajdonságai szabályozhatóak. A PLA kopolimerjei közül a legelterjedtebb a glikolsav mellett előállított poli(tejsav-ko-glikolsav). A láncban lévő glikolsav mennyiségét növelve a hidrofilitása és degradációs sebessége is megnövelhető. Hidrolízise során tejsav és glikolsav monomeregységek képződnek, ami 
metabolikus úton a Krebs-ciklus révén lebontható [77]. Ennek köszönhetően a PLGA kopolimerek minimális toxicitással rendelkeznek, így hatóanyag hordozó rendszerként való felhasználásukban nagy potenciál rejlik.

A PLA/PLGA polimereket a szintézis módszertől függően különböző molekulatömegek mellett is előállíthatjuk. A könnyebb átláthatóság érdekében és a polimerizációs/kopolimerizációs módszerek közötti hasonlóság miatt (kezdeti tiszta tejsav helyett tejsav-glikolsav keverék alkalmazása) a szintézis módszereket a PLA esetében mutatjuk be részletesen. A PLA szintézise számos polimerizációs folyamattal kivitelezhető, melyek közül a legismertebbek a (közvetlen, szilárd állapotú) kondenzációs polimerizációs (polikondenzációs), az azeotróp dehidratációs és a gyürüfelnyitásos polimerizációs (ROP) eljárások [74,78,79]. A nagy molekulatömegü PLA makromolekulák előállítására legtöbb esetben a ROP módszert alkalmazzák, ahol a polimert a tejsav ciklikus dimerjének gyürüfelnyitásával állítják elö. A szintézis tömb és oldat fázisban is kivitelezhető, ahol egy katalizátor és iniciátor segítségével a laktid gyürük kinyílnak és összekapcsolódnak. A katalizátortól függően a polimerizáció anionos, kationos és koordinációs mechanizmus alapján is lejátszódhat [80]. Katalizátorként jól alkalmazható az ón(II)-2-etilhexanoát, az alumínium(III)-izopropoxid vagy a cink(II)-laktát stb., míg iniciátorként 1-dodekanolt alkalmaznak gyakorta. A PLA-n kívül ezen ROP technika a nagy molekulatömegű PLGA kopolimerek előállítására is kiválóan alkalmazható. Ebben az esetben a szintéziskor a laktid és a glikolsav ciklikus dimerjének (glikolid) megfelelő arányok melletti keverékét használják, ahogyan azt a 7. ábra is szemlélteti.
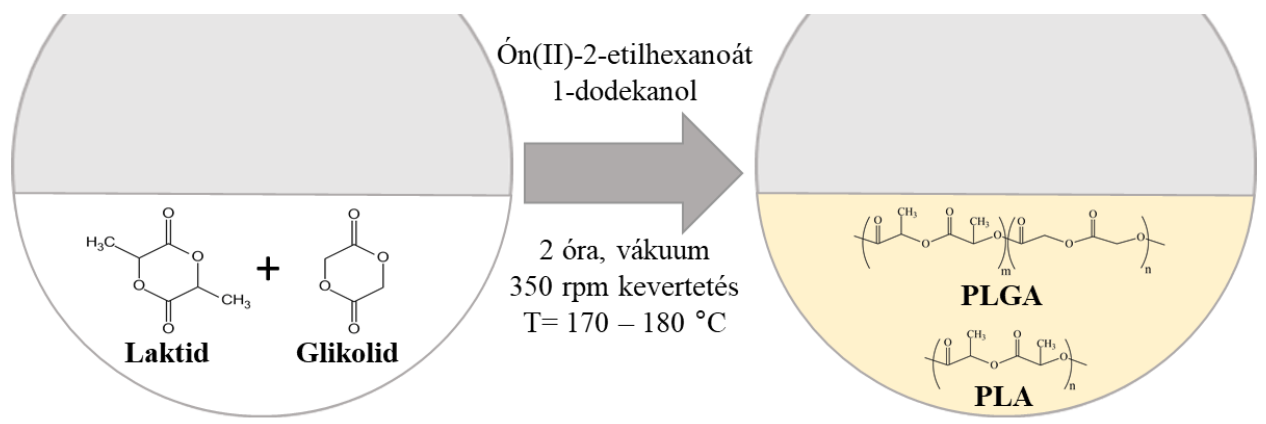

7. ábra: PLA/PLGA makromolekulák gyürüfelnyitásos polimerizációval (ROP) történő szintézisének sematikus ábrája

Korábban C.D.C. Erbetta és munkatársai 50:50 (PLGA50) és 70:30 (PLGA70) laktid:glikolid arányok beállítása mellett már állított elő ROP eljárással PLGA kopolimereket [81]. Fourier-transzformációs infravörös (FT-IR) spektroszkópiás, mágneses 
magrezonancia (NMR) spektroszkópiás, differenciális pásztázó kalorimetriás (DSC) és termogravimetriás (TG) módszereket felhasználva igazolták, hogy kopolimerizációs folyamatok sikeresen lejátszódtak és az előállított polimer minták visszamaradt monomer szennyezéstől mentesek. A.T.C.R Silva és munkatársai hasonló körülmények között

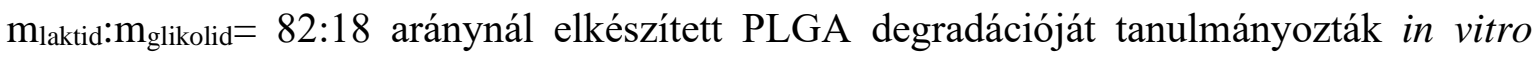
körülmények között különböző módszerek segítségével (FT-IR, DSC, TG, reológia, pásztázó elektronmikroszkóp (SEM)) [82].

A könnyen kivitelezhető elöállítási technikáknak és viszonylag magas hatóanyag bevitelnek köszönhetően a PLA/PLGA nanorészecskék, illetve nanokapszulák előállításával kapcsolatban számos publikáció található a szakirodalomban [83]. Hidrofób hatóanyagok esetében főleg nanoprecipitációs, vagy emulziós eljárást alkalmaznak a leggyakrabban, míg hidrofil hatóanyagoknál a duplaemulziós vagy (megfelelő szerves fázis kiválasztása mellett) szintén a nanoprecipitációs technikát. Az előállítási és tisztítási eljárások során beállítható paraméterek változtatásával a részecskék stabilitása, mérete és szerkezete szabályozható. Ilyen befolyásoló hatása lehet például a kezdeti koncentrációknak, a hőmérsékletnek, az oldószereknek, vagy a felhasznált polimerek molekulatömegének [84]. A PLGA nanorészecskék előállításával kapcsolatos kutatások fő célja a hordozó rendszer adott hatóanyagokra való optimalizálása, ahol a vizsgálatok során beállított kezdeti paraméterek jelentősen eltérhetnek, ami megnehezíti az eredmények összevethetőségét.

A kutatómunkánk során a korábbi alfejezetben már részletezett nanoprecipitációs módszert alkalmaztuk PLA/PLGA alapú kolloid részecskék előállítására [85,86], ahol a

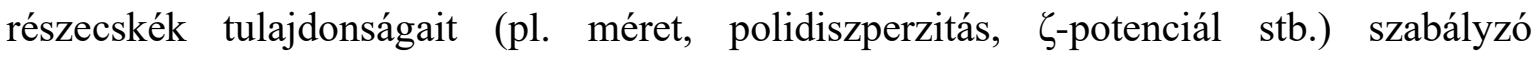
paraméterek megismerését célzó publikációkból számos olvasható a szakirodalomban. W. Huang és C. Zhang a nanoprecipitációs módszerrel előállított PLGA részecskék méretének szabályozhatóságát vizsgálták különböző paramétereken [87]. Eredményeikkel rámutattak arra, hogy a megfelelő szerves oldószer kiválasztásával, a polimer koncentráció és a vizes fázis ionerősségének csökkentésével, illetve a hömérséklet növelésével a részecskék mérete csökkenthető. U. Bilati és munkatársai főként hidrofil hatóanyagok kapszulázására alkalmazható nanoprecipitációs eljárásnál a polimer oldószer, a kicsapószer, az oldószer arány és a polimerek koncentráció hatását vizsgálták [54]. A mérések jelentős részében kicsapószerként különböző alkoholokat használtak, ahol a beállított körülményektől függően 85-560 nm közötti részecskeméreteket kaptak. A részecske kicsapására használt közeget figyelembe véve azt tapasztalták, hogy azonos körülmények között a homológ sor szerint a metanol<etanol<propanol kicsapószer közegben a részecskék átmérője 
folyamatosan nő (stabilizátor nélküli közegben 102 nm -től (metanol) 377 nm átmérőig (izopropanol)). R. Lancheros és munkatársai a már $N$-acetilcisztein-tartalmú PLGA50 (poli(laktid-ko-glikolid, laktid:glikolid arány 50:50) részecskék méretének és kapszulázási hatékonyságát jellemezték a pH, a koncentráció, az oldószerek, az oldószerarányok és a molekulatömeg függvényében [88]. Az előállított részecskéken végzett dinamikus fényszórás (DLS) mérések igazolták, hogy a polimer molekulatömegének és koncentrációjának csökkentésével, míg a szerves:vizes oldószerarány növelésével és a Casó jelenlétével a részecskeméret $250 \mathrm{~nm}$ alá is csökkenthető. Az előbbi publikációkat összegezve jól látható a módszer sokszínűsége, ami megnehezíti a rendszert befolyásoló hatások széleskörü megismerését. Ennek köszönhető, hogy a részecskék méretét, szerkezetét és stabilitását nagymértékben szabályzó számos egyéb paraméter befolyásoló hatása még kevésbé ismert, ezért a rendszerek karakterizálásával kapcsolatos kutatások kiemelkedő fontosságúak.

A hatóanyag kapszulázását, a fent említett paraméterek mellett, a gyógyszerszármazékok és a polimerek hidrofilitása is befolyásolja. J. M. Baricello és munkatársai korábbi munkájuk során a hidrofil és hidrofób hatóanyagok kapszulázhatóságát vizsgálták PLGA75 (poli(laktid-ko-glikolid), laktid:glikolid arány 75:25) ( $\left.\mathrm{M}_{\mathrm{w}}=10000 \mathrm{Da}\right)$ ) és Pluronic F68 stabilizátor esetében [89]. A méréseikkel igazolták, hogy a nanoprecipitációs módszerrel előállított, átlagosan 160-170 nm átmérővel rendelkező, részecskéknél a lipofil hatóanyagok kapszulázása eredményesebb. Fontos megjegyezni, hogy a polimerek és hatóanyagok hidrofilitási sajátságainak a részecskék méretére, kapszulázási hatékonyságára és stabilitására gyakorolt együttes hatása kevésbé ismert. Mindezek mellett az előállítás során keletkezett részecskék szerkezetével (nanogömb vagy nanokapszula) a kioldódási folyamatok nagy mértékben megváltozhatnak [27], így ezek meghatározása is nagy jelentőséggel bír.

\subsubsection{HyA alapú kolloid rendszerek}

A hialuronsav egy $\beta$-(1 $\rightarrow 4)$ kapcsolt $D$-glükuronsav és $\beta$ - $(1 \rightarrow 3)$ kapcsolt $N$-acetil- $D$ glükózamin egységekből álló, energetikailag stabil szerkezettel rendelkező mukopoliszacharid, melyet elsőként Karl Meyer és John Palmer fedezett fel a marhák szem üvegtestében [90]. A hialuronsav az extracelluláris mátrix egyik komponense, illetve minden emlősállatban megtalálható (pl kötőszövetekben, ízületi folyadékban) só formájában (hialuronát) [91]. 
Kiváló biokompatibilitásának és viszkozitási tulajdonságainak köszönhetően orvosbiológiai (pl. hatóanyagszállítás, szemészet) és kozmetikában egyaránt alkalmazzák [92-95]. A HyA alapú hidrogélek viszkozitásának tanulmányozására gyakran használnak reológiai méréseket. Ennek fontossága abban rejlik, hogy a molekulatömegtől, a koncentrációtól és a szerkezettől (pl. térhálósítás [96], neutralizálás [97]) a hidrogélek viszkozitási tulajdonsága jelentősen változhat, ami kiemelt szereppel bír akár hidratáló gélről akár ízületi folyadékként/ízületi fájdalmak kezelésére való felhasználásról beszélünk [90]. Alacsonyabb koncentrációjú HyA gélek pszeudoplasztikus viselkedést mutatnak, így magasabb nyírási sebességeknél a viszkozitásuk csökkenni kezd, ami elönyös a gélek injektálásánál [91]. Mindezek mellett a polimer láncok „feltekeredésének” eredményeként viszkoelasztikus viselkedés is megfigyelhető. Frekvencia sepréses oszcillációs reológiai mérésekkel igazolták, hogy magasabb frekvenciaértékeknél a HyA gélek Newtoni viselkedése elasztikusra vált [98]. Fontos megjegyezni, hogy a hordozó rendszerek vizsgálatánál releváns nagyon kis koncentrációjú HyA molekuláris oldataival kapcsolatban kevés információ található.

A HyA polimerlánc tengelyétől ekvatoriálisan elhelyezkedő hidroxil-, karboxil- és acetamidocsoportoknak köszönhetően a HyA hidrogénkötések kialakítására képes, aminek eredményeként kiemelkedő hidrofilitással és vízoldékonysággal rendelkezik [99]. A láncokon lévő hidrogén atomok viszont kismértékben hidrofób jelleget adnak a polimernek, ezáltal a hialuronsav amfifil tulajdonsággal is rendelkezik. Ez a sajátsága teszi alkalmassá a hordozó nanorészecskék előállítására. A hialuronsav karboxilcsoportjának alacsony $\mathrm{pK}_{\mathrm{a}}$-ja ( $\mathrm{pK}_{\mathrm{a}} \sim 2,9$ [100]) miatt fiziológiás körülmények között negatív töltéssel rendelkezik, ezáltal kationos komponenseket elektrosztatikus kölcsönhatások révén képes megkötni, mely hatóanyag hordozóként betöltött szerepét tovább erősíti.

A HyA negatív töltése révén elektrosztatikusan kötött héj szerkezet kialakítására is képes a hordozóként alkalmazni kívánt részecskék felületén. H. Tian és munkatársaik ennek megfelelően alakított ki HyA héjat inzulin-tartalmú $N$-(2-hidroxi-propil)-3-trimetilammónium-kloriddal módosított kitozán (HTCC) magra [101], ahol az optimalizált körülmények között folyamatos müködésü nanokomplexációs technikával tiolcsoport nélküli és tiolcsoporttal rendelkező (SH-HyA) HyA makromolekulával átlagosan $100 \mathrm{~nm}$ részecskeméretet és $~ 90 \%$ kapszulázási hatékonyságot tudtak elérni. Az előállítás metodikáját és a részecskékről készített reprezentatív TEM képeket a 8. ábra mutatja. 


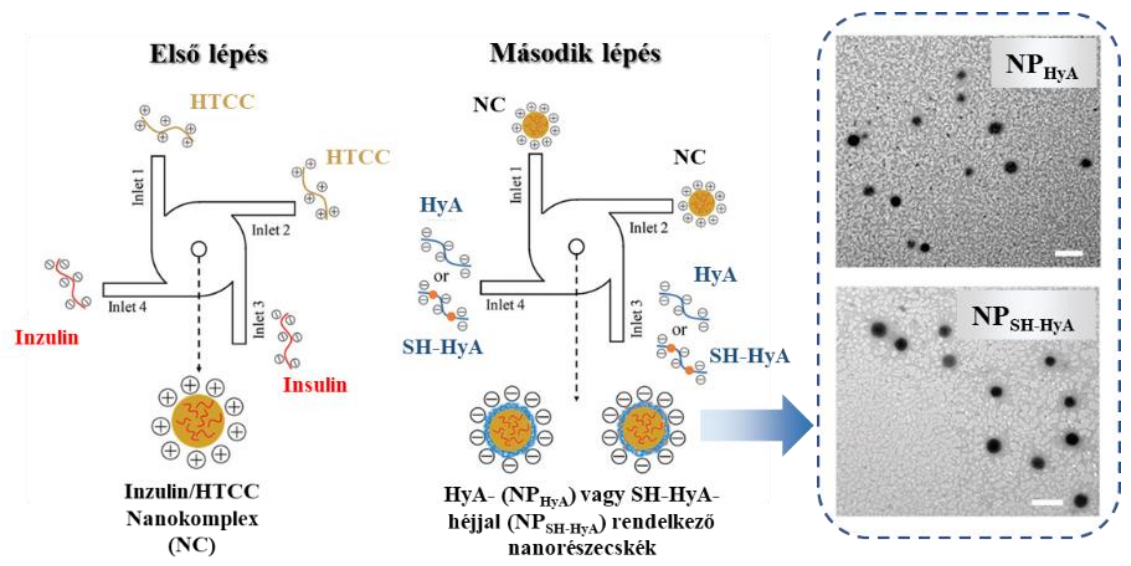

8. ábra: HyA és SH-HyA-héjjal rendelkező inzulin/HTCC részecskék előállítása folyamatos működésű „nanokomplexálási” technikával és a részecskékről készített TEM képek [101]

A HyA részecskék előállítására a korábban már említett kovalens keresztkötésen vagy gyengébb elektrosztatikus kölcsönhatásokon alapuló gélesítési technikák is felhasználhatóak. Keresztkötött HyA származékok (pl. adipinsav-dihidraziddal módosított és poli(etilén-glikol)-lal keresztkötött HyA [102], $\alpha, \beta$-poli(aszpartil-hidrazid)-dal keresztkötött HyA [103]) közül a gyakran alkalmazzák a karbodiimides technikát [60,104,105], ahol a polimer láncon lévő karboxilcsoportokat diaminos keresztkötő ágenssel kapcsoljuk össze kovalens kötéseket kialakítva. A módszer során stabil részecskék előállítása is lehetséges. M. Bodnár és munkatársai diaminos keresztkötési technikával sikeresen állítottak elő HyA (továbbiakban cl-HyA) nanorészecskéket [60]. A vizsgálataik során $4350 \mathrm{kDa}$ molekulatömegü poliszacharid mellett annak $\mathrm{pH}=2,0$ értéken és $70{ }^{\circ} \mathrm{C}$-on degradált $980 \mathrm{kDa}(3 \mathrm{~h}), 660 \mathrm{kDa}(6 \mathrm{~h})$ és $350 \mathrm{kDa}(9$ h) mólsúlyú fragmenseit használták. A 25, 50 és $100 \%$-os térhálósítással szintetizált részecskék jelentős polidiszperzitással rendelkeztek, ahol a kezdeti HyA molekulatömegétől és a keresztkötés mértékétől függően $\mathrm{d}=50-110 \mathrm{~nm}$ és d= 210-500 nm hidrodinamikai átmérőket tudtak elérni. A HyA részecskék előállítására ritkábban használt módszer a neutralizálás, ahol kationos komponensek segítségével (pl. tenziddel, fehérjével vagy polimerrel) töltéskompenzálás révén hidrofóbizálható a makromolekula [106]. Ilyen polielektrolit komplexekként ismertek a különböző Chit-HyA alapú rendszerek, melyeket gélként vagy „állványzat” -ként (scaffoldok) szövet gyógyuláshoz és növekedéshez is elterjedten használnak [107]. A keresztkötött és neutralizált módszerek előnye, hogy a polimer láncok részleges módosításával, a közeg pH-jával, a molekulatömeggel stb. a HyA tulajdonságai szabályozhatóak. A részecskék karakterizálásán kívül a kialakuló kölcsönhatások jellemzésére (föleg a töltéskompenzálással előállított rendszereknél) nagy igény van. 


\section{Célkitüzés}

Néhány éve kutatócsoportunk egyik fő kutatási területét képezi főként szérum albumin alapú kolloidális hatóanyag hordozó részecskék előállítása és szerkezetvizsgálata [23-25]. Felhasználásuk révén a Kutatócsoport munkatársai korábban sikeresen valósították meg neuroaktív vegyületek vér-agy gáton való átjuttatását, melyet elfogadott magyarországi szabadalom is igazol. Ezen kutatásokhoz kapcsolódtam 2017. őszén, ahol egy újonnan elnyert GINOP-2.3.2 pályázat keretein belül, kiemelt feladatom volt új típusú, döntően polimer és poliszacharid alapú hatóanyag hordozó rendszerek tervezése, optimalizálása és reprodukálható szintézisek kidolgozása. Mindezek mellett fő feladatom volt az előállított rendszerek méretének, szerkezetének, kapszulázási hatékonyságának és lehetőség szerint a hatóanyag felszabadulás kinetikájának tanulmányozása és értelmezése.

A szakirodalomban széles körben használt PLA/PLGA hatóanyag hordozó rendszerek előállítására egy jól alkalmazható technika az oldószercserén alapuló nanoprecipitációs módszer [43]. Az eljárás alkalmazásakor a részecskék szerkezetét, méretét és a hatóanyagok kapszulázási hatékonyságát jelentősen befolyásolhatják az előállításoknál alkalmazott kezdeti paraméterek (pl.: molekulatömeg, stabilizátor típusa, $\mathrm{pH}$, koncentráció stb.). Az irodalomban PLA/PLGA makromolekulákon kívül a HyA poliszacharidot is egyre elterjedten alkalmazzák hatóanyag hordozó rendszerek kialakítására [92]. Jól ismert, hogy ezen poliszacharid szerkezeti módosításával (pl. térhálósítás, neutralizálás), a PLA/PLGA polimerekhez hasonlóan, kolloid részecskék állíthatóak elő. illetve a szerkezeti módosítás típusától és kísérleti körülményeitől függően, a részecskék méretétől egészen a hatóanyag leadásig, számos szerkezeti és funkcionális paraméter szabályozható.

Mindezen ismereteket szem előtt tartva, doktori munkám során célul tűztük ki PLA és eltérő hidrofilitási tulajdonsággal rendelkező PLGA kopolimerek előállítását és lehetséges felhasználásukat kolloidális hatóanyag hordozó részecskék előállítására. Vizsgálataink során tanulmányozni kívántuk egyrészt, hogy különböző töltésủ és molekulatömegủ stabilizátorok (cetil-trimetil-ammónium-bromid (CTAB), polivinil-alkohol (PVA), Pluronic F127 (PLUR)), illetve eltérő forráspontú és sürüségü oldószerek (aceton, 1,4-dioxán) felhasználása révén a makromolekulás kolloidokból felépülő hatóanyag hordozó részecskék stabilitása, mérete és morfológiája milyen mértékben változtatható. Értelmezni kívántuk továbbá a modellként alkalmazott, eltérő oldékonyságú, töltésű és szerkezetű hatóanyag molekuláknak (ketoprofen (KP), ( \pm )- $\alpha$-tokoferol (TP), $D$ - $\alpha$-tokoferol-polietilén-glikol- 
1000-szukcinát (TPGS)) a részecskék szerkezetére, méretére és kapszulázási hatékonyságára gyakorolt hatását is.

Kutatómunkám másik fő feladata volt a nanoprecipitációs eljárással előállított PLA/PLGA alapú, TP hatóanyag-tartalmú kolloid részecskék előállításának megvalósítása folyamatos áramlási technikával is. Tanulmányozni kívántuk, hogy a preparálás során lehetségesen beállítandó paraméterek (pl.: kiindulási koncentráció, áramlási sebesség, áramlási sebesség arányok, nyomás) szisztematikus változtatása révén szabályozható-e reproduktívan a részecskék mérete, szerkezete vagy éppen a hatóanyag tartalom. Az előállított részecskék in vitro körülmények közti kioldódási folyamatainak vizsgálata is a munka részét képezte. Célunk volt összehasonlítani, hogy ezen eljárás ígéretesnek mutatkozik-e az irodalomban gyakorta alkalmazott nanoprecipitációs technika mellett.

A PLA/PLGA hordozó rendszerekkel kapcsolatos vizsgálatok mellett az értekezés másik nagy fejezetét képezte a rendkívül hidrofil tulajdonságú, közepes molekulatömegü HyA (M-HyA) makromolekula hatóanyag hordozóként történő alkalmazhatóságának feltérképezése is hidrofób KP molekulák kapszulázására a poliszacharid eltérő mértékü térhálósításának kivitelezése révén. Mindezeken túl célunk volt tanulmányozni, hogy hidrofób KP molekulák kapszulázása megvalósítható-e a M-HyA pozitív töltésü felületaktív anyaggal $(\mathrm{CTAB})$ történő részleges neutralizálása révén is. A kétféle eljárással előállított kolloid részecskék teljeskörü szerkezeti karakterizálása mellett a hatóanyag hordozókból történő kioldódási folyamatának feltérképezése is a vizsgálataink részét képezte.

A HyA felületaktív anyaggal történő részleges neutralizálási folyamatának ismeretében az értekezésben további célul tüztük ki annak tanulmányozását is, hogy előállítható-e HyA alapú hordozó részecske, ha a CTAB helyettesítésére egy monomer egységenként egy pozitív töltésű makromolekulát, a kitozánt alkalmazzuk. Meghatározni kívántuk, hogy a monomer egységenként egy negatív töltéssel rendelkező nagy molekulatömegü HyA (H-HyA) és az egy pozitív töltéssel rendelkező Chit között fellépő elektrosztatikus kölcsönhatások mértéke hogyan változik a HyA/Chit tömegarányok változtatásnak hatására. Az optimalizált arányok ismeretében megkíséreltük különböző típusú HyA/Chit alapú komplex hordozó részecskék előállítását és a képződő kolloid részecskék szerkezetvizsgálatát is, de ez a rész már nem képezte szerves részét az értekezésemnek. 


\section{Felhasznált anyagok, szintézisek és vizsgálati módszerek}

\subsection{Felhasznált anyagok}

- 3,6-dimetil-1,4-dioxán-2,5-dion (LA, D,L-laktid, $\mathrm{C}_{6} \mathrm{H}_{8} \mathrm{O}_{4}, \geq 99 \%$, Sigma)

- 1,4-dioxán-2,5-dion (GA, glikolid, $\mathrm{C}_{4} \mathrm{H}_{4} \mathrm{O}_{4}, \geq 99 \%$, Sigma)

- Ón(II)-2-etilhexanoát $\left(\mathrm{C}_{16} \mathrm{H}_{30} \mathrm{O}_{4} \mathrm{Sn}, \geq 96 \%\right.$, Alfa Aesar $)$

- 1-dodekanol $\left(\mathrm{C}_{12} \mathrm{H}_{26} \mathrm{O}, \geq 98 \%\right.$, Fluka $)$

- 2,2'(etiléndioxi)bisz(etilamin) (EDEA, $\mathrm{NH}_{2} \mathrm{CH}_{2} \mathrm{CH}_{2} \mathrm{OCH}_{2} \mathrm{CH}_{2} \mathrm{OCH}_{2} \mathrm{CH}_{2} \mathrm{NH}_{2}, \geq 98$ $\%$, Sigma)

- 1-[3-(dimetil-amino)propil]-3-etil-karbodiimid-metil-jodid (EDC metil-jodid, $\mathrm{C}_{2} \mathrm{H}_{5} \mathrm{~N}=\mathrm{C}=\mathrm{N}\left(\mathrm{CH}_{2}\right)_{3} \mathrm{~N}\left(\mathrm{CH}_{3}\right)_{3} \mathrm{I}, \geq 99 \%$, Sigma $)$

- Pluronic F127 (PLUR, $\left(\mathrm{OCH}_{2} \mathrm{CH}_{2}\right)_{\mathrm{x}}\left(\mathrm{OCH}_{2} \mathrm{CH}\left(\mathrm{CH}_{3}\right)\right)_{\mathrm{y}}\left(\mathrm{OCH}_{2} \mathrm{CH}_{2}\right)_{\mathrm{z}}, \mathrm{M}_{\mathrm{w}} \approx 12,6 \mathrm{kDa}$, $\geq 99 \%$, Sigma)

- Polivinil-alkohol (PVA, $\left(\mathrm{C}_{2} \mathrm{H}_{4} \mathrm{O}\right)_{\mathrm{x}}, \mathrm{M}_{\mathrm{w}} \approx 72 \mathrm{kDa}, \geq 99 \%$, Sigma)

- Cetil-trimetil-ammónium-bromid (CTAB, $\mathrm{CH}_{3}\left(\mathrm{CH}_{2}\right)_{15} \mathrm{~N}(\mathrm{Br})\left(\mathrm{CH}_{3}\right)_{3}, \geq 95 \%$, Sigma)

- ( $( \pm)$ - $\alpha$-tokoferol (TP, $\mathrm{C}_{29} \mathrm{H}_{50} \mathrm{O}_{2}, \geq 96 \%$, Sigma)

- $\quad D$ - $\alpha$-tokoferol-polietilén-glikol-1000-szukcinát (TPGS, $\left(\mathrm{C}_{2} \mathrm{H}_{4} \mathrm{O}\right)_{\mathrm{x}}\left(\mathrm{C}_{33} \mathrm{H}_{54} \mathrm{O}_{5}\right), \geq 99$ $\%$, Sigma)

- $\quad$ Ketoprofen (KP, $\mathrm{C}_{16} \mathrm{H}_{14} \mathrm{O}_{3}, \geq 98 \%$, Sigma)

- Poli(tejsav) (PLA, $\left(\mathrm{C}_{3} \mathrm{H}_{4} \mathrm{O}_{2}\right)_{\mathrm{x}}, \mathrm{M}_{\mathrm{w}}=250 \mathrm{kDa}, \geq 99 \%$, Fluka)

- Poli(laktid-ko-glikolid) (PLGA75, $\left(\mathrm{C}_{6} \mathrm{H}_{8} \mathrm{O}_{4}\right)_{\mathrm{x}}\left(\mathrm{C}_{4} \mathrm{H}_{4} \mathrm{O}_{4}\right)_{\mathrm{y}}$, laktid:glikolid arány 75:25, $\mathrm{M}_{\mathrm{w}}=40-75 \mathrm{kDa}, \geq 99 \%$, Sigma)

- Poli(laktid-ko-glikolid) (PLGA65, $\left(\mathrm{C}_{6} \mathrm{H}_{8} \mathrm{O}_{4}\right)_{\mathrm{x}}\left(\mathrm{C}_{4} \mathrm{H}_{4} \mathrm{O}_{4}\right)_{\mathrm{y}}$, laktid:glikolid arány 65:35, $\mathrm{M}_{\mathrm{w}}=60-107 \mathrm{kDa}, \geq 99 \%$, Sigma $)$

- Poli(laktid-ko-glikolid) (PLGA50, $\left(\mathrm{C}_{6} \mathrm{H}_{8} \mathrm{O}_{4}\right)_{\mathrm{x}}\left(\mathrm{C}_{4} \mathrm{H}_{4} \mathrm{O}_{4}\right)_{\mathrm{y}}$, laktid:glikolid arány 50:50, $\mathrm{M}_{\mathrm{w}}=30-60 \mathrm{kDa}, \geq 99 \%$, Sigma $)$

- Közepes molekulatömegü kitozán (M-Chit., $\left(\mathrm{C}_{6} \mathrm{H}_{11} \mathrm{O}_{4} \mathrm{~N}_{1}\right)_{\mathrm{x}}, \mathrm{M}_{\mathrm{w}}=190-310$ kDa, 75$85 \%$ deacetilezett, Sigma)

- $\quad$ Nagy molekulatömegü kitozán (H-Chit, $\left(\mathrm{C}_{6} \mathrm{H}_{11} \mathrm{O}_{4} \mathrm{~N}_{1}\right)_{\mathrm{x}}, \mathrm{M}_{\mathrm{w}}=310-375 \mathrm{kDa}, \geq 75 \%$ deacetilezett, Sigma)

- Közepes molekulatömegű nátrium-hialuronát (M-HyA, $\left(\mathrm{C}_{14} \mathrm{H}_{21} \mathrm{O}_{11} \mathrm{~N}_{1}\right)_{\mathrm{x}}, \mathrm{M}_{\mathrm{w}}=1,5-$ $1,8 \times 10^{3} \mathrm{kDa}, \leq 1 \%$ fehérje, Sigma)

- Nagy molekulatömegü nátrium-hialuronát (H-HyA, $\left(\mathrm{C}_{14} \mathrm{H}_{21} \mathrm{O}_{11} \mathrm{~N}_{1}\right)_{\mathrm{x}}, \mathrm{M}_{\mathrm{w}}=200-500$ kDa, Richter Gedeon Nyrt.) 
- Dinátrium hidrogén-foszfát $\left(\mathrm{Na}_{2} \mathrm{HSO}_{4}, \geq 99 \%\right.$, Molar $)$

- Nátrium-dihidrogén-foszfát monohidrát $\left(\mathrm{NaH}_{2} \mathrm{SO}_{4} \times \mathrm{H}_{2} \mathrm{O}, \geq 99 \%\right.$, Sigma $)$

- $\quad$ Nátrium-klorid ( $\mathrm{NaCl}, \geq 99 \%$, Molar $)$

- $\quad$ Tripolifoszfát (TPP, $\mathrm{Na}_{5} \mathrm{P}_{3} \mathrm{O}_{10}, \geq 98 \%$, Merk KGaA)

- $\quad$ Nátrium hidroxid $(\mathrm{NaOH}, \geq 99 \%$, Molar $)$

- $\quad$ Sósav $(\mathrm{HCl}, 37 \%$, Molar $)$

- $\quad$ Ecetsav $\left(\mathrm{CH}_{3} \mathrm{COOH}, \geq 99,5 \%\right.$, Erdökémia $)$

- 1,4-dioxán $\left(\mathrm{C}_{4} \mathrm{H}_{8} \mathrm{O}_{2}, \geq 99,8 \%\right.$, Sigma $)$

- Aceton $\left(\mathrm{CH}_{3} \mathrm{COCH}_{3}, \geq 99,5 \%\right.$, Sigma $)$

- Etanol $\left(\mathrm{CH}_{3} \mathrm{CH}_{2} \mathrm{OH}, \geq 99,9 \%\right.$, Molar $)$

- cellulóz alapú dialízis membrán (cut off: 14000, Sigma)

A hatóanyag tartalmú hordozó rendszerek előállításához felhasznált polimerek monomer egységeit, illetve a hatóanyagok szerkezeti képleteit a 9. ábra foglalja össze.
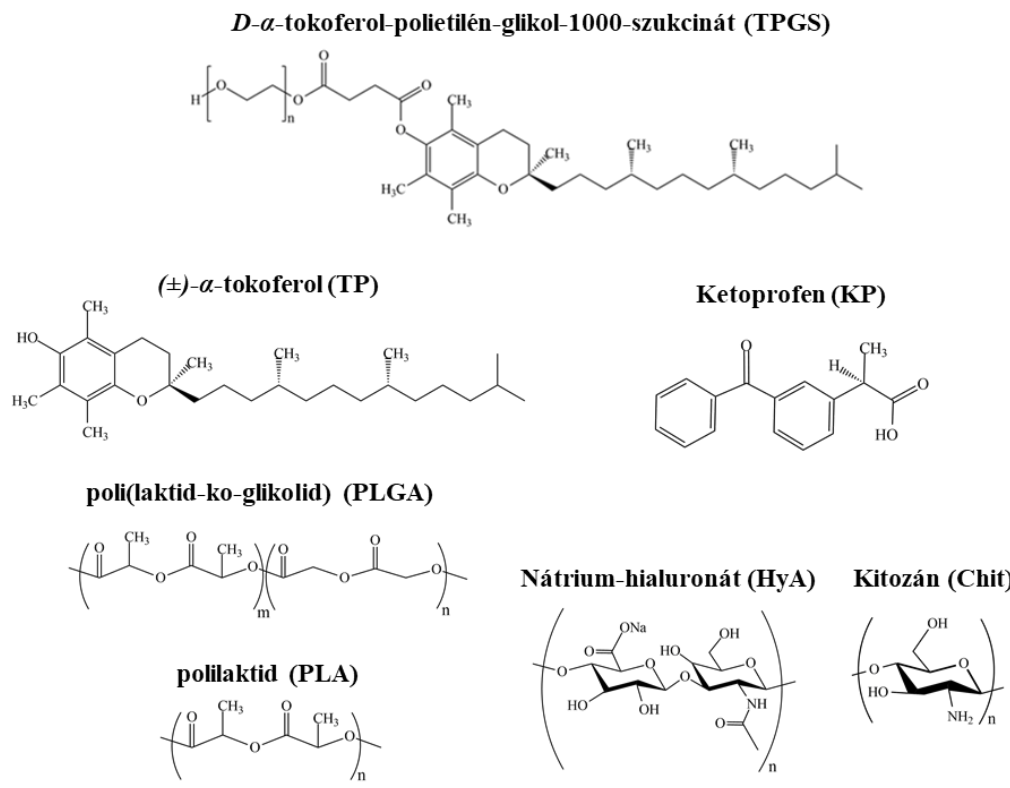

9. ábra: A hordozó rendszerek előállításához használt polimerek monomer egységei és a hatóanyagok szerkezeti képletei

A mérésekhez alkalmazott vegyszerek analitikai tisztaságúak voltak, ezért felhasználásuk előtt további tisztításra nem volt szükség. A vizes közegű oldatokhoz és polimer alapú részecskék előállításához minden esetben nagy tisztaságú Milli-Q vizet (Millipore, Milli-Q, Integral3, fajlagos ellenállás $18,2 \mathrm{~m} \Omega \times \mathrm{cm} 25^{\circ} \mathrm{C}$-on) alkalmaztunk. A hatóanyag kioldódásával kapcsolatos vizsgálatoknál, illetve a szintéziseknél heti 
rendszerességgel elkészített $\mathrm{NaCl}$ tartalmú foszfát puffert (továbbiakban $\mathrm{PBS}, \mathrm{pH}=7,4$ ) használtunk. A PBS oldat a következő összetétellel rendelkezett: 2,25 g NaCl (0,15 M, 0,9 $\mathrm{m} / \mathrm{m} \%$ ), 0,5497 $\mathrm{g} \mathrm{Na}_{2} \mathrm{HPO}_{4}$ és $0,1558 \mathrm{~g} \mathrm{NaH}_{2} \mathrm{PO}_{4} \times \mathrm{H}_{2} \mathrm{O} 250 \mathrm{~cm}^{3}$ térfogatú, Milli-Q vízben feloldva.

\subsection{Szintézisek}

\subsubsection{Poli(laktid-ko-glikolid) kopolimerek szintézise}

A PLA és különböző hidrofilitási tulajdonsággal rendelkező PLGA kopolimereket gyürü-felnyitásos polimerizációval (ROP) állítottuk elő $[81,82,108]$. Ehhez a reakcióhoz a tejsav és a glikolsav ciklusos dimerjét ( $D, L$-laktid és glikolid), ón(II)-2-etilhexanoát katalizátort és 1-dodekanol iniciátort használtuk. A szintézis alatt az ón(II)-2-etilhexanoát a polimerizációs folyamatot katalizálja, míg az 1-dodekanol kettős szerepének köszönhetően aktiválja a katalizátort és nukleofil ágensként elősegíti a ciklikus dimerek gyürüfelnyitását. Az eljárás során a szükséges mennyiségü laktidot (PLA: 5,0015 g; PLGA75: 3,7520 g; PLGA65: 3,2513 g), glikolidot (PLA: 0 g; PLGA75: 1,2510 g; PLGA65: 1,75602 g) ${ }^{3}, 0,02$ w/w\% (teljes dimer tömegre nézve) ón(II)-2-etilhexanoát katalizátort és $0,01 \mathrm{w} / \mathrm{w} \%$ (a teljes dimer tömegre nézve) 1-dodekanol iniciátort egy gömblombikban homogenizáltuk és a rendszert vákuum alá helyeztük. A polimerizáció elindításához a lombikot $\mathrm{T}=170-180{ }^{\circ} \mathrm{C}-$ ig előmelegített olajfürdőbe tettük és - a homogenitás fenntartása érdekében - a mintát 2 órán át kevertettük. Az ilyen módon nyert végterméket $-20{ }^{\circ} \mathrm{C}$ hőmérsékleten tároltuk. Mivel mind az iniciátor, mind a katalizátor nagyon kis mennyiségben volt jelen a reakcióelegyben, így az irodalmi hivatkozásoknak megfelelően, [81,82], további tisztítási eljárást nem alkalmaztunk.

\subsubsection{PLA/PLGA hordozó rendszerek szintézise nanoprecipitációs módszerrel}

A szintetizált PLA/PLGA polimerekből a részecskék előállítása nanoprecipitációs technikával történt, ahol a kísérleteket több oldószerben és számos stabilizálószer alkalmazása mellett is kiviteleztük. A törzsoldatok elkészítésekor a polimereket minden esetben szerves oldószerben (aceton vagy 1,4-dioxán), míg a stabilizátorokat (CTAB, PVA, PLUR) nagy tisztaságú Milli-Q vízben oldottuk. A szerves:vizes fázisok térfogatarányát mindig 1:10 értéken tartottuk.

\footnotetext{
${ }^{3}$ Az egyes laktid és glikolid mennyiségek az adott jelzésű PLA/PLGA75/PLGA65 származékok elóállításához szükséges mennyiségeket mutatják.
} 
A polimer hidrofilitásának ill. a stabilizátorok és az oldószerek hatásának tanulmányozásához a PLA/PLGA makromolekulák 15-15 mg mennyiségét feloldottuk 1,5 mL szerves oldószerben, majd a kapott törzsoldatot $15 \mathrm{~mL} 0,1 \mathrm{mg} / \mathrm{mL}$ koncentrációjú stabilizátor-tartalmú vizes oldatba csepegtettük $10 \mu \mathrm{L} / 5$ s sebességgel, szobahőmérsékleten. A folyamat során a komponenseket mágneses keverőt használva 1000 rpm fordulatszámmal kevertettük.

A hatóanyag (KP, TP, TPGS)-tartalmú PLA/PLGA részecskék előállításánál az előzőkkel megegyező koncentrációkat és szintézis körülményeket alkalmaztunk. A hatóanyagok 7,5-7,5 mg mennyiségét (polimer:hatóanyag 1:2 tömegarány) oldékonyságuknak megfelelően a szerves fázisú polimert (KP, TP) vagy a vizes fázisú stabilizátort (TPGS) tartalmazó oldatokhoz adtuk. A modellként választott három hatóanyag közül a legrosszabb vízoldékonysággal rendelkező TP esetén koncentrációfüggő előállítási kísérleteket is végeztünk. A részecskék szintézisét első körben PLA polimer, PLUR stabilizátor és aceton oldószer alkalmazása mellett végeztük el. Ebben az esetben a 1,2510,0 mg/mL PLA és 0,0-5,0 mg/mL TP koncentrációjú acetonos törzsoldatokat 10-10 mL 0,0-1,0 $\mathrm{mg} / \mathrm{mL}$ koncentrációjú PLUR oldatokba cseppentettük a fentebb már említett szintézis paraméterek alkalmazása mellett (1000 rpm, $10 \mu \mathrm{L} / 5 \mathrm{~s}$ adagolási sebesség, $25^{\circ} \mathrm{C}$ ). Az egyes mintáknál beállított komponens koncentrációkat az 1. táblázat foglalja össze.

1. táblázat: A PLA alapú, TP-tartalmú kolloid részecskék előállításához használt komponensek koncentráció és térfogat adatai

\begin{tabular}{|c|c|c|c|}
\hline \multirow[b]{2}{*}{ Minta } & \multicolumn{2}{|c|}{ Aceton fázis } & \multirow{2}{*}{$\begin{array}{c}\text { Vizes Fázis } \\
\text { cPLUR } \\
(\mathrm{mg} / \mathrm{mL})\end{array}$} \\
\hline & $\begin{array}{c}c_{P L A} \\
(\mathbf{m g} / \mathbf{m L})\end{array}$ & $\begin{array}{c}\mathbf{c}_{\mathrm{TP}} \\
(\mathrm{mg} / \mathrm{mL})\end{array}$ & \\
\hline 1 & 1,25 & 2,5 & 0,10 \\
\hline 2 & 2,50 & 2,5 & 0,10 \\
\hline 3 & 5,00 & 2,5 & 0,10 \\
\hline 4 & 10,0 & 2,5 & 0,10 \\
\hline 5 & 10,0 & 0,0 & 0,10 \\
\hline 6 & 10,0 & 0,5 & 0,10 \\
\hline 7 & 10,0 & 1,0 & 0,10 \\
\hline 8 & 10,0 & 2,5 & 0,10 \\
\hline 9 & 10,0 & 5,0 & 0,10 \\
\hline 10 & 10,0 & 2,5 & 0,00 \\
\hline 11 & 10,0 & 2,5 & 0,05 \\
\hline 12 & 10,0 & 2,5 & 0,10 \\
\hline 13 & 10,0 & 2,5 & 0,50 \\
\hline 14 & 10,0 & 2,5 & 1,00 \\
\hline
\end{tabular}

A vizsgálatokat a PLGA65 és PLGA75 alapú rendszerek esetén is elvégeztük a PLA esetén optimalizált arányok alapján. Ezeket, mint új tudományos eredményeket az 5. fejezet 
foglalja össze. A nanoprecipitációs módszerrel elöállított diszperziókat minden esetben 48 h-ig 350 rpm fordulatszámon kevertettük, majd tisztítottuk. A tisztításkor a mintákat további 40-40 mL Milli-Q vízzel hígítottuk és $12000 \mathrm{rpm}$ fordulatszámon $\left(\mathrm{t}=15 \mathrm{~min}, \mathrm{~T}=25^{\circ} \mathrm{C}\right)$ centrifugáltuk egy Hermle Z36HK centrifugával. Az így kapott felülúszót eltávolítottuk és a részecskéket $40 \mathrm{~mL}$ Milli-Q vízben diszpergáltuk, majd ezen tisztítási eljárást kétszer is megismételtük.

\subsubsection{PLGA50 részecskék elöállitása áramlásos rendszerben}

A PLGA50 részecskék áramlásos technikával történő előállításához $5,0 \mathrm{mg} / \mathrm{mL}$ koncentrációjú PLGA50 kopolimert és $1,25 \mathrm{mg} / \mathrm{mL}$ koncentrációban TP-t tartalmazó acetonos oldatot és $0,1 \mathrm{mg} / \mathrm{mL}$ koncentrációjú vizes PLUR oldatot használtunk. A méréseket hatóanyag nélkül is elvégeztük. A részecskék szintéziséhez két fecskendő pumpával, nyomás kontrollerrel és egy $250 \mu \mathrm{L}$ térfogatú három bemenetű $\mu$-mixer cellával rendelkező Syrris Asia Flow rendszert használtunk. A módszer sematikus ábráját a 10. ábra szemlélteti. A szintézis folyamán a két törzsoldatot a fecskendő pumpák juttatják el a $\mu$-mixer cellába, ahol a fázisok keveredése révén a PLGA50 precipitációja megtörténik és kolloid részecskék képződnek. A méréseket különböző áramlási sebességeken (szerves fázis: $\mathrm{v}_{1}=25-150$ $\mu \mathrm{L} /$ perc, vizes fázis: $\mathrm{v}_{2}=250-1500 \mu \mathrm{L} /$ perc, $\mathrm{v}_{1}: \mathrm{v}_{2}$ arány állandó) eltérő áramlási sebesség arányokon $\left(\mathrm{v}_{1}=25 \mu \mathrm{L} / \mathrm{min}\right.$ állandó, $\left.\mathrm{v}_{2} / \mathrm{v}_{1}=10-50\right)$ és különböző cella nyomásokon $\left(\mathrm{v}_{1}=25\right.$ $\mu \mathrm{L} /$ perc, $\mathrm{v}_{2}=250 \mu \mathrm{L} /$ perc, $\mathrm{p}=2-10 \mathrm{bar}$ ) is elvégeztük. A polimer diszperziók tisztítása a nanoprecipitációs módszernél korábban már említett eljárással történt.

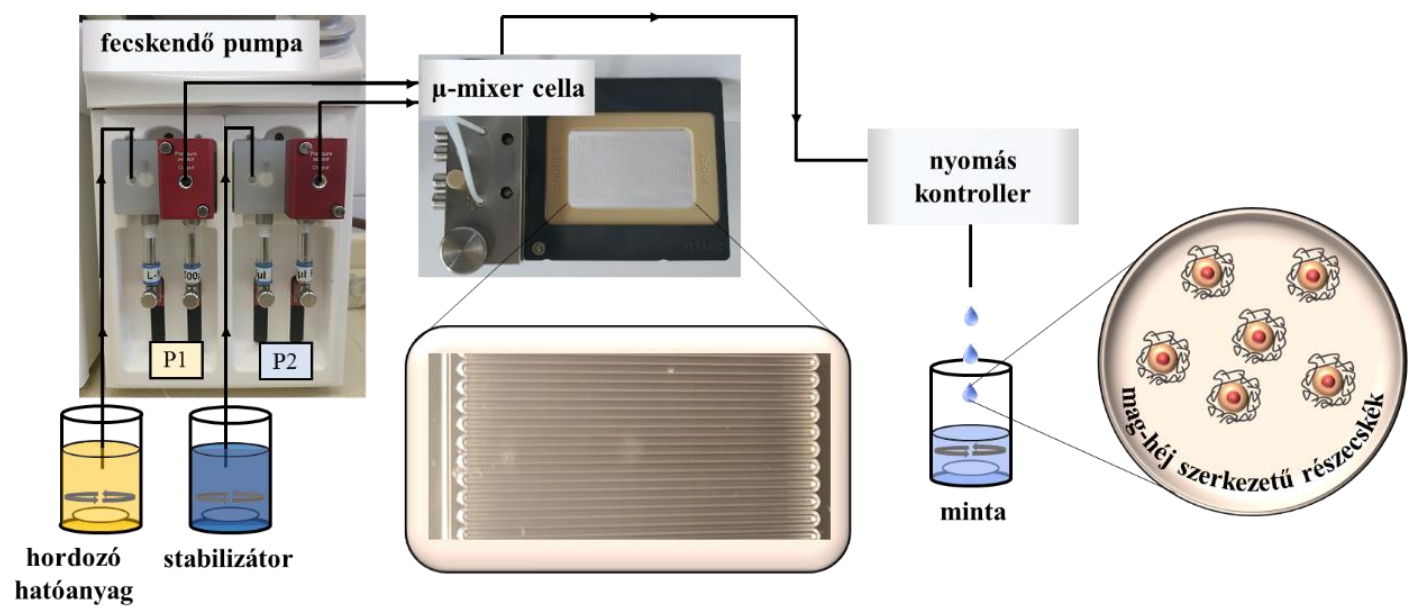

10. ábra: A PLGA50 kopolimer alapú kolloid részecskék előállításához használt Syrris Asia Flow áramlásos rendszer sematikus ábrája 


\subsubsection{Térhálósitott nátrium-hialuronát részecskék elöállitása}

Az eltérő mértékben keresztkötött M-HyA (továbbiakban $c l-M-H y A / 50 \%, c l-M$ $H y A / 75 \%$ és $c l-M-H y A / 100 \%$ ) részecskék előállításához a jelölésben megadott $50 \%, 75 \%$ és 100\% mértékü térhálósítást alkalmaztunk. A szintézis első lépéseként $200 \mathrm{~mL} 1 \mathrm{mg} / \mathrm{mL}$ koncentrációjú vizes M-HyA oldatokat készítettünk, amelyek pH-ját $\mathrm{pH}=5,5$ értékre állítottuk be $0,1 \mathrm{M}$ koncentrációjú $\mathrm{NaOH}$ oldattal. Ezen oldatokhoz a keresztkötés mértékét figyelembe véve rendre 1,88 mL (50\%), 2,82 mL (75\%) és 3,76 mL (100\%) EDEA oldatot $(1 \mathrm{v} / \mathrm{v} \%, \mathrm{pH}=5,5)$ adtunk. A reakcióelegyhez 30 perces kevertetés után $80 \mathrm{mg}(50 \%), 120$ mg (75\%) és 160 mg (100\%) EDC metil-jodidot tartalmazó vizes oldatot csepegtettünk. Az így elkészített termékeket egy éjszakán át kevertettük, majd a termékeket 7 napon keresztül nagy tisztaságú Milli-Q vízben dialízissel tisztítottuk. A HyA alapú kolloid részecskék képződése a térhálósítással párhuzamosan megtörténik. A KP-tartalmú cl-M-HyA alapú rendszerek előállítása állandó ionerősségü PBS oldatban $(\mathrm{pH}=7,40 ; 0,9 \% \mathrm{NaCl})$ történt, mivel a KP vízoldékonysága puffermentes közegben alacsony $\left(\mathrm{c}_{\mathrm{KP}, \max }=0,051 \mathrm{mg} / \mathrm{mL}\right)$. A cl-M-HyA/KP minták előállításánál $20 \mathrm{mg} / \mathrm{mL}$ KP és $100 \mathrm{mg} / \mathrm{mL}$ előzetesen szintetizált és liofilizált cl-M-HyA/50\%, 75\% és 100\% tartalmú elegyeket készítettünk, majd 24 óráig kevertettük öket. A tisztítás folyamata során a mintákat $0,1 \mathrm{v} / \mathrm{v} \%$ koncentráció eléréséig hígítottuk és 8000 rpm fordulatszámon 10 percig centrifugáltuk a felesleges és nem kötött hatóanyag eltávolítása végett.

\subsubsection{M-HyA/CTAB kompozit részecskék elöállitása}

A M-HyA/CTAB részecskék tanulmányozásához elkészített oldatsorozatnál 0,2 $\mathrm{mg} / \mathrm{mL}$ M-HyA koncentráció mellett a CTAB mennyiségét 0,00-0,26 mg/mL között szisztematikusan változtattuk PBS közegben $\left(\mathrm{m}_{\mathrm{CTAB}} / \mathrm{m}_{\mathrm{HyA}}=0-1,3\right)$. A CTAB koncentrációjának beállításához $0,02 \mathrm{M}$ koncentrációjú törzsoldatot használtunk. A KP hatóanyagot is tartalmazó M-HyA/CTAB minták előállításakor a cl-M-HyA/KP rendszerhez hasonlóan PBS közegben végeztük vizsgálatainkat. A kapszulázást $20 \%$-, 50 \%- és $80 \%$ ban neutralizált M-HyA/CTAB mintáknál végeztük el, ahol az oldatokban a M-HyA és a KP koncentrációja $\mathrm{c}_{\mathrm{HyA}}=100 \mathrm{mg} / \mathrm{mL}$ és $\mathrm{c}_{\mathrm{KP}}=20 \mathrm{mg} / \mathrm{mL}$, míg a CTAB mennyisége $18 \mathrm{mg} / \mathrm{mL}$, $46 \mathrm{mg} / \mathrm{mL}$, és $73 \mathrm{mg} / \mathrm{mL}$ volt. A mintákat 24 óráig kevertettük és a 4.2.4. alfejezetben említett módon tisztítottuk. 


\subsection{Vizsgálati módszerek és mérési körülmények}

\subsubsection{A hordozó rendszerek jellemzésére szolgáló módszerek és technikák}

A Fourier-transzformációs infravörös (FT-IR) spektroszkópiás mérésekhez egy egyszeres reflexiójú ATR Pro One feltéttel ellátott Jasco FT/IR-4700 spektrométert használtunk. A vizsgálatokhoz liofilizált pormintákat alkalmaztunk. A spektrumokat 256 interferogram átlagolásával, $4 \mathrm{~cm}^{-1}$ felbontással, $400-4000 \mathrm{~cm}^{-1}$ tartományon vettük fel. A detektált karakterisztikus rezgési sávok alapján a szintetizált és módosított biopolimerekben végbement szerkezeti változásokról kaptunk információt.

A differenciális pásztázó kalorimetriás (DSC), termogravimetriás (TG) és a differenciális termoanalitikai (DTA) mérések kivitelezése egy Mettler-Toledo 822e kaloriméterrel és egy Mettler-Toledo TG/SDTA 851 ${ }^{\mathrm{e}}$ müszerrel történt. A detektált DSC görbéket 25-500 ${ }^{\circ} \mathrm{C}$, míg a TG és DTA görbéket 25-1000 ${ }^{\circ} \mathrm{C}$ közötti hőmérséklettartományon vettük fel $5{ }^{\circ} \mathrm{C} /$ perc felfütési idő és $50 \mathrm{~mL} /$ perc áramlási sebességü nitrogén (DSC) és levegő (TG, DTA) közeg beállítása mellett. Az eredményeket STARe 12.10 szoftverrel értékeltük ki.

A PLA/PLGA polimerek hidrofilitási tulajdonságainak jellemzésekor elvégzett peremszög mérésekhez egy $0,5 \mathrm{~mm}$ átmérőjü, acél tűvel felszerelt fecskendővel és egy nagy felbontású kamerával rendelkező KRÜSS FM40Mk2 Easy Drop müszert használtunk. A vizsgált PLA/PLGA film rétegeket az egyes polimerek $160-170^{\circ} \mathrm{C}$ hömérsékleten, mikroszkóp tárgylemez üveg felületére történő olvasztásával állítottunk elő. A peremszög értékeket $25^{\circ} \mathrm{C}$ hőmérsékleten és légköri nyomáson határoztuk meg 5-5 párhuzamos mérés átlagából, ahol nagy tisztaságú Milli-Q vízből cseppentettünk 1-1 cseppet (10-10 $\mu \mathrm{L}$ mennyiséget) a polimer filmek felületére.

A szintetizált PLA/PLGA kopolimerek molekulatömegének meghatározásához egy Horiba SZ-100 típusú fényszórásmérőt használtunk $\left(\lambda_{\text {lézer }}=532 \mathrm{~nm}\right)$. A molekulatömeg $\left(\mathrm{M}_{\mathrm{w}}\right)$ és a második viriál együttható $\left(A_{2}\right)$ értékeket a Rayleigh-Gans-Debye modellel (1. egyenlet) kaptuk meg:

$$
\frac{\mathrm{Kc}}{\mathrm{R}_{\mathrm{ex}}}=\frac{1}{\mathrm{M}_{\mathrm{W}}}+2 \mathrm{~A}_{2} \mathrm{c}
$$

ahol $\boldsymbol{K}$ a Debye konstans, $\boldsymbol{c}$ a minta koncentrációja, $\boldsymbol{R}_{\boldsymbol{e}}$ a többlet Rayleigh arány, $\boldsymbol{M}_{\boldsymbol{w}}$ az átlagos molekulatömeg és $\boldsymbol{A}_{2}$ a második viriál együttható. 
A Debye konstans értéke a 2. egyenlet alapján határozható meg:

$$
\mathrm{K}=\frac{4 \pi^{2} \mathrm{n}_{0}^{2}(\mathrm{dn} / \mathrm{dc})^{2}}{\lambda^{4} \mathrm{~N}_{\mathrm{A}}}
$$

ahol $\boldsymbol{n}_{\boldsymbol{0}}$ a diszperziós közeg törésmutatója, $\boldsymbol{d n} / \boldsymbol{d} \boldsymbol{c}$ a minta törésmutatójának növekedése a koncentráció függvényében, $\lambda$ az alkalmazott fény hullámhossza vákuumban és $N_{A}$ az Avogadro szám. Mindezeken felül a többlet Rayleigh arányt a következőképpen határozhatjuk meg (3. egyenlet):

$$
\mathrm{R}_{\mathrm{ex}}=\mathrm{R}_{\mathrm{ref}} \frac{\mathrm{n}_{0}^{2}}{\mathrm{n}_{\mathrm{ref}}^{2}}\left(\frac{\mathrm{I}_{\mathrm{minta}}-\mathrm{I}_{0}}{\mathrm{I}_{\mathrm{ref}}}\right)
$$

ahol $\boldsymbol{R}_{\boldsymbol{e x}}$ a többlet Rayleigh arány, $\boldsymbol{R}_{\boldsymbol{r} e f}$ egy jól ismert referencia közeg Rayleigh aránya, $\boldsymbol{n}_{0}$ a diszperziós közeg törésmutatója, $\boldsymbol{n}_{\text {ref }}$ a referencia közeg törésmutatója, $\boldsymbol{I}_{\text {minta }}$ a mért minta szórásintenzitása, $\boldsymbol{I}_{\boldsymbol{0}}$ a diszperziós közeg szórásintenzitása és $\boldsymbol{I}_{\boldsymbol{r} e f}$ a referencia közeg szórásintenzitása.

A vizsgálatok során $0-20 \mathrm{mg} / \mathrm{mL}$ koncentrációjú PLA/PLGA 1,4-dioxán közegü oldatait használtunk. A Debye konstans determinálásához fontos $d n / d c$ értéket a mérésekhez elkészített oldatok Mettler Toledo RM50 típusú refraktométerrel meghatározott törésmutató értékei alapján határoztuk meg. A többlet Rayleigh arány kiszámításához referencia oldószerként toluolt használtunk. A módszer érzékenységére tekintettel a felhasznált analitikai tisztaságú oldószereket (előzetesen 1,4-dioxánnal, toluollal és Milli-Q víz) előzetesen $0,2 \mu \mathrm{m}$ pórusméretü szürőn átszürtük (szerves oldószereknél: Hidrofób PTFE szürő, Milli-Q víznél: Hidrofil Nylon szürő).

A HyA/Chit rendszernél töltéstitrálási méréseket végeztünk a két makromolekula közötti töltéskompenzálási pont kvantitatív meghatározásához, melyhez egy Mütek PCD-04 részecske töltés detektort alkalmaztunk. A mérések során 10-10 mL 0,5-2,0\% ecetsavas közegü 0,045 mg/mL koncentrációjú HyA oldatokat titráltunk 0,091 mg/mL koncentrációjú (az előzőkkel azonos ecetsavas közegü) Chit oldattal, ahol 125-125 $\mu \mathrm{L}$ adagokban adtuk a Chit oldatot és minden pontban az áramlási potenciál értékeket rögzítettük. A HyA töltéskompenzálási pontját (un. áttöltési pontot, ahol a mért áramlási potenciál értéke eléri a $0 \mathrm{mV}$-os értéket) a titrálási görbék módosított Boltzmann egyenlettel (4. egyenlet) történő illesztéséből határoztuk meg [109], figyelembe véve, hogy a szigmoid görbék torzultak: 


$$
\mathrm{Y}=\frac{\mathrm{a}_{1} \mathrm{x}+\mathrm{a}_{2}}{1+\exp \left[\left(\mathrm{x}-\mathrm{a}_{4}\right) / \mathrm{a}_{3}\right]}+\mathrm{a}_{5} \mathrm{x}+\mathrm{a}_{6}
$$

ahol $\boldsymbol{Y}$ a függő változó (a mért áramlási potenciál értékek), $\boldsymbol{x}$ a független változó (Chit és HyA mólaránya) és $\boldsymbol{a}_{i}$ az illesztési paraméterek. Az $\boldsymbol{a}_{1}$ és $\boldsymbol{a}_{2}$ a titrálási görbe alsó és felső szakaszának aszimptotikus értékéi, $\boldsymbol{a}_{3}$ az átmeneti szakasz szélessége, $\boldsymbol{a}_{4}$ az inflexiós pontban az $\boldsymbol{x}$ független változó értéke, míg az $\left(\boldsymbol{a}_{1} \boldsymbol{a}_{4}\right)+\boldsymbol{a}_{2}$ kifejezés az inflexiós pontban a titrálási görbe alsó és felső szakaszának távolsága (a függő változó mértékegységében). Az egyenlet számlálójában és a jobb oldalt lévő kifejezés figyelembe veszi az induló és megállapodó tartomány eltolódását. A paramétereket ismerve kiszámíthatjuk a Chit:HyA mólarányokat az áttöltési pontjában $(\mathrm{Y}=0 \mathrm{mV})$.

Az izoterm titrációs kalorimetriás (ITC) mérések kivitelezése a HyA/CTAB alapú hordozó rendszerek esetében Dr. Juhász Ádám (SZTE TTIK Fizikai Kémiai és Anyagtudományi Tanszék) segítségével történtek. Az egyes entalprogramok rögzítéséhez egy számítógép kontrollált MicroCal VP-ITC típusú izoterm titrációs kalorimétert alkalmaztunk, amely egy 1,4301 mL mintacellával és $300 \mu \mathrm{L}$ össztérfogatú fecskendővel rendelkezik. A mintacellában titrálandó oldatként 1,4 mL 0,1 mg/mL koncentrációjú HyA oldatot használtunk, míg titrálószerként $12 \mathrm{mM}$ és $5 \mathrm{mM}$ koncentrációjú CTAB oldatot. A mérések kivitelezése révén a CTAB kritikus micellaképződési koncentrációját $(\mathrm{cmc})$ kívántuk meghatározni HyA jelenlétében. Referenciaként a CTAB $c m c$ értékét is meghatároztuk, ahol a titrálandó oldat nagy tisztaságú Milli-Q víz volt. A mérések $25{ }^{\circ} \mathrm{C}$ hőmérsékleten és $10 \mu \mathrm{L} / 5$ perc adagolási sebességen zajlottak. Az entalpogrammok kiértékelése egy Origin Microcal 7.1 szoftverrel történt. A CTAB $c m c$ értékét a töltéstitrálási vizsgálatoknál bemutatott módosított Boltzmann egyenlettel (4. egyenlet) határoztuk meg, ahol független változó a tenzid koncentrációja $(x=c)$, míg a függő változók a mért entalpia értékek $(\boldsymbol{Y}=\boldsymbol{\Delta} \boldsymbol{H})$ voltak.

A TP oldhatóságának meghatározásához, továbbá a hatóanyag nélküli M-HyA/CTAB kompozitok szerkezeti jellemzéséhez és a PLGA kopolimerekkel kapcsolatos precipitációs titrálások minősítéséhez turbidimetriás méréseket végeztünk, melyhez egy LP2000 Hanna Ins. típusú zavarosságmérő készüléket és utóbbi esetben egy Ocean Optics USB4000 egyfényutas spektrofotométert használtunk. A fotometriás mérések esetében $650 \mathrm{~nm}$ hullámhosszon detektáltunk és a méréseket $1 \mathrm{~cm}$ úthosszú kétoldalú kvarc küvettában végeztük el. A polimerek precipitációs tulajdonságait az abszorbancia és $100 \%$ turbiditás esetében mért maximum abszorbancia arányt a Milli-Q víz térfogat és a teljes térfogat arányának függvényében ábrázolt görbék segítségével határoztuk meg. 
A M-HyA/CTAB rendszernél a konduktometriás titrálási görbék rögzítése egy Radelkis OK-114 konduktométerrel történt szobahőmérsékleten. A mérések kivitelezése révén a $\mathrm{CTAB} c m c$ értékét kívántuk meghatározni HyA jelenlétében. Referenciaként a CTAB $c m c$ értékét is meghatároztuk. A mérések során a vezetőképesség értékeket rögzítettük, amely során 20-20 mL nagy tisztaságú Milli-Q vízhez és 0,1 mg/mL koncentrációjú M-HyA oldathoz adagoltunk külön-külön 20 mM CTAB oldat 40-40 $\mu \mathrm{L}$ mennyiségeit.

A reológiai mérések kivitelezésében Dr. Juhász Ádám segédkezett. A vizsgálatokat egy Anton Paar MCR 301 típusú reométerrel végeztük el dupla rés (DG26.7-SN12740), kúplap (CP25-1-SN12204) és koncentrikus henger (CC27-SN12740) geometriájú feltétekkel 25 $\pm 0,1^{\circ} \mathrm{C}$ - os hőmérsékleten. Annak érdekében, hogy a hőmérséklet állandósuljon $\mathrm{a}$ rendszerben a mintákat 5 percig a feltétben állni hagytuk.

A kis koncentrációjú $(0,05-0,1 \quad \mathrm{mg} / \mathrm{mL}) \quad$ M-HyA oldatok viszkozitási és nyírófeszültség értékeit 1-300 1/s nyírósebességen és dupla rés geometriájú feltéttel határoztuk meg. A nagy koncentráció M-HyA (25-100 mg/mL) oldatok esetében a méréseket kúp-lap geometriájú feltéttel végeztük el 1-40 1/s nyírósebesség tartományon. A tömény M-HyA tixotróp tulajdonságának meghatározásakor a viszkozitási értékeket növekvő és csökkenő nyírósebességeken is megvizsgáltuk. A folyásgörbéket Bingham modellel (5. egyenlet), illetve az egyes viszkozitási görbékre illesztett Carreau-Yasuda egyenlettel (6. egyenlet) értékeltük ki a RheoPlus szoftver segítségével.

$$
\tau=\tau_{\mathrm{B}}+\eta_{\mathrm{p} 1} \dot{\gamma}
$$

ahol $\boldsymbol{\tau}$ a nyírófeszültség, $\boldsymbol{\tau}_{\boldsymbol{B}}$ a lineáris szakaszból nulla nyírósebességre történő extrapolálással meghatározott Bingham-féle folyáshatár és $\boldsymbol{\eta}_{\boldsymbol{p}}$ az egyenes meredekségéből kapott plasztikus viszkozitás.

$$
\eta=\eta_{\infty}+\left(\eta_{0}-\eta_{\infty}\right)\left[1+(\lambda \dot{\gamma})^{\mathrm{a}}\right]^{(\mathrm{n}-1) / \mathrm{a}}
$$

ahol $\boldsymbol{\eta}$ a viszkozitás, $\boldsymbol{\eta}_{\infty}$ a végtelen-nyírási viszkozitás, $\boldsymbol{\eta}_{\boldsymbol{0}}$ a nulla-nyírási viszkozitás, $\dot{\gamma}$ a nyírósebesség, $\boldsymbol{t}$ a relaxációs idő, $\boldsymbol{n}(\mathrm{n}<1)$ és $\boldsymbol{a}$ konstans.

A konstans nyírási sebességeken elvégzett reológiai méréseknél a koncentrikus henger geometriájú feltétben lévő $19 \mathrm{~mL}$ 0,1 mg/mL kezdeti koncentrációjú HyA oldatokat titráltunk meg $25 \mathrm{mM}$ CTAB ( 5 percenként $20 \mu \mathrm{L}$ ) és $2 \mathrm{mg} / \mathrm{mL}$ Chit ( 3 percenként $40 \mu \mathrm{L}$ ) törzsoldattal. A M-HyA/CTAB rendszernél a méréseket nagy tisztaságú Milli-Q vízben, míg 
a M_Chit/H-HyA esetében 0,5-2 v/v\%-ban ecetsavat is tartalmazó közegben végeztük el. A viszkozitás változását $25 \pm 0,1^{\circ} \mathrm{C} \quad$-on, $150 \quad 1 / s \quad$ (CTAB) és $300 \quad 1 / s \quad$ (M-Chit) nyírósebességeken követtük. A rendszer hígulása miatt bekövetkező viszkozitás-csökkenés korrigálása érdekében a titrálásokat a megfelelő tiszta oldószerekkel is elvégeztük. A HyA gélek viszkoelasztikus paramétereinek tanulmányozásához amplitúdó sepréses oszcillációs reológiai méréseket használtunk, ahol a mintákat szinuszos nyírási deformációnak (nyírás, nyírási alakváltozás) tettük ki. A nyírási deformációra az alábbi 7. egyenletet írhatjuk fel:

$$
\gamma=\gamma_{0} \sin (\omega \mathrm{t})
$$

ahol $\boldsymbol{\gamma}$ a nyírási deformáció, $\gamma_{0}$ a nyírási deformáció amplitúdója, $\omega$ az oszcillációs frekvencia és $\boldsymbol{t}$ az idő.

A viszkoelasztikus anyagok elasztikus (Hooke-test) és viszkózus (Newton-test) sajátságait a nyírófeszültségből ( $\boldsymbol{\tau})$ kifejezett 8. egyenlet alapján jellemezhetjük:

$$
\tau=\mathrm{G}^{\prime}(\omega) \gamma_{0} \sin (\omega \mathrm{t})+\mathrm{G}^{\prime \prime}(\omega) \gamma_{0} \cos (\omega \mathrm{t})
$$

ahol $\gamma_{0}$ a nyírási deformáció amplitúdója, $\boldsymbol{\omega}$ az oszcillációs frekvencia, $\boldsymbol{t}$ az idő, $\boldsymbol{G}$ 'az elasztikus tulajdonságot jellemző tárolási modulus, $\boldsymbol{G}$ '” a viszkózus tulajdonságot jellemző veszteségi modulus. A tárolási és veszteségi modulus arányát a veszteségtangens adja meg (9. egyenlet):

$$
\tan \delta=\frac{\mathrm{G}^{\prime \prime}}{\mathrm{G}^{\prime}}
$$

Az egyenletben szereplő $\delta$ a fáziseltolódás, amelynek fokba megadott értékéből következtethetünk az anyag folyási tulajdonságát (ideális elasztikus: $\delta=0^{\circ}$, viszkoelasztikus: $0^{\circ}<\delta<90^{\circ}$, ideálisan viszkózus: $\delta=90^{\circ}$ ). A tömény és módosított (neutralizálás, térhálósítás) HyA géleknél alkalmazott amplitúdó sepréses módszer esetén a nyírás folyamatos növelése mellett (0,01-100 \%) meghatároztuk a G', G'’ ill. a korábban már említett szoftverrel a

folyási pontot $\left(\boldsymbol{\tau}_{f p}\right)$ és keresztezési pontot $\left(\gamma_{c o p}\right)$ állandó $10 \mathrm{~Hz}$-es oszcillációs frekvencián. A mérések kivitelezéséhez kúp-lap geometriájú feltétet és $\mathrm{T}=25 \pm 0,1{ }^{\circ} \mathrm{C}$ használtunk.

\subsubsection{Részecskék méretének és szerkezetének meghatározása}

A dinamikus fényszórás (DLS) és ל-potenciál méréseket a PLA/PLGA és Chit/HyA részecskéknél a korábban említett Horiba SZ-100 típusú, míg a HyA/CTAB és cl-M-HyA rendszereknél egy Malvern NanoZS fényszórásmérővel ( $\lambda_{\text {lézer }}=633 \mathrm{~nm}$, He-Ne lézer) 
végeztük $25 \pm 0,1^{\circ} \mathrm{C}$-on. A hidrodinamikai átmérő ( $\mathrm{d}_{\mathrm{DLS}}$ ), a polidiszperzitási index (PDI) és a ל̧- potenciál értékeket legalább 5-5 mérési eredmény átlagolásával határoztuk meg.

A transzmissziós elektronmikroszkópos (TEM) képeket Dr. Varga Viktória (SZTE TTIK Fizikai Kémiai és Anyagtudományi Tanszék) segítségével egy Jeol JEM-1400plus típusú transzmissziós elektronmikroszkóppal vettük fel $120 \mathrm{keV}$ gyorsítófeszültségen. A nagyfelbontású transzmissziós elektronmikroszkópos (HRTEM) képek készítésénél Janóné Dr. Ungor Ditta Anita (SZTE TTIK Fizikai Kémiai és Anyagtudományi Tanszék) segédkezett, ahol egy FEI Tecnai G2 20 X-Twin típusú transzmissziós elektronmikroszkópot alkalmaztunk, $200 \mathrm{kV}$ gyorsítófeszültség beállítása mellett. Az átmérők ( $\left.\mathrm{d}_{\mathrm{TEM}}\right)$ átlagos értékének meghatározásához ImageJ szoftvert használtunk. A TEM képek segítségével információt kaptunk a részecskék szerkezetéről és az átlagos méretéről, méreteloszlásáról.

\subsubsection{Kapszulázási hatékonyság és in vitro hatóanyag kioldódási vizsgálatok}

Az egyes hordozó makromolekulák kapszulázási hatékonyságának meghatározásához és a hatóanyagok in vitro kioldódásának követéséhez UV-Vis spektrofotometriás módszert alkalmaztunk. A spektrumokat, illetve a kalibrációs görbéket 200-500 nm hullámhossz tartományon és $1 \mathrm{~cm}$ úthosszú kvarc küvettában rögzítettük egy Shimadzu UV-1800 két fényutas spektrofotométer segítségével. A kapszulázási hatékonyság értékét ( $\boldsymbol{E} \boldsymbol{E}(\boldsymbol{\%}))$ és a részecskék hatóanyag töltöttségét $(D L(\%))$ az alábbi 10. és 11. egyenletekkel határoztuk meg:

$$
\begin{aligned}
& \mathrm{EE}(\%)=\frac{\text { hatóanyag kapszulázott tömege }}{\text { hatóanyag teljes tömege }} \times 100 \\
& \mathrm{DL}(\%)=\frac{\text { hatóanyag kapszulázott tömege }}{\text { részecskék teljes tömege }} \times 100
\end{aligned}
$$

$\mathrm{Az}$ in vitro kioldódási vizsgálatokat foszfát pufferes (PBS, $\mathrm{pH}=7,4 ; 0,9 \% \mathrm{NaCl}$ ) közegben és féligáteresztő cellulóz dialízis membránnal végeztük el. A cl-M-HyA/KP és MHyA/CTAB/KP kapcsolatos mérések $25^{\circ} \mathrm{C}$-os, míg a PLA/TP és PLGA/TP esetében $37{ }^{\circ} \mathrm{C}$ -os hömérsékleten történtek. A PLA/PLGA rendszereknél a hidrofób tulajdonsággal rendelkező TP oldhatóságának növelése érdekében a PBS közeg $1 \mathrm{mg} / \mathrm{mL}$ koncentrációban PLUR stabilizátort is tartalmazott.

A hatóanyag kioldódás kinetikájának és mechanizmusának meghatározása végett a felvett kioldódási görbékre különböző kinetikai modelleket illesztettük, melyhez egy QtiPlot 
0.9.8.9. svn 2288 programot használtunk. A számolások során a szoftver nemlineáris regresszióval minimalizálja a mért és közelítő koncentráció értékek közötti különbségek négyzetösszegét. A modell illesztések után információt kapunk az egyes kinetikai állandókról, a kioldódás mechanizmusát jellemző paraméterek értékéről, az illesztés jóságáról, illetve a standard deviációról. A számolásokat az elsőrendű, Korsmeyer-Peppas, Weibull és Peppas-Shalin modelleknél végeztük el [110-112].

Az elsörendü egyenlet széles körben használják olyan folyamatoknál, ahol a kioldódás csak a hatóanyag koncentrációjától függ. A modell a 12. egyenlettel írható le:

$$
\frac{c_{t}}{c_{0}}=e^{-k t}
$$

ahol $\boldsymbol{c}_{\boldsymbol{t}}$ a hordozó mátrixban lévő hatóanyag koncentrációja $\boldsymbol{t}$ időpillanatban, $\boldsymbol{c}_{\boldsymbol{0}}$ a hatóanyag kezdeti koncentrációja a hordozóban és $\boldsymbol{k}$ az elsőrendủ kioldódási állandó.

A kioldódási görbék kiértékeléséhez előszeretettel alkalmazzák a Korsmeyer-Peppas szemi-empirikus egyenletet. A modell elönye, hogy a polimer mátrix alakját (gömb, film, henger) is figyelembe veszi (13. egyenlet):

$$
\frac{\mathrm{c}_{\mathrm{t}}}{\mathrm{c}_{0}}=\mathrm{k}_{\mathrm{m}} \mathrm{t}^{\mathrm{n}}
$$

ahol $\boldsymbol{c}_{\boldsymbol{t}}$ a felszabadult hatóanyag koncentrációja $\boldsymbol{t}$ időpillanatban $\boldsymbol{c}_{\boldsymbol{0}}$ a hatóanyag kezdeti koncentrációja a hordozóban, $\boldsymbol{k}_{\boldsymbol{m}}$ a kinetikai állandó és $\boldsymbol{n}$ a diffúziós-oldódási index, amely a hatóanyag kioldódás mechanizmusát jellemzi.

Ha $\boldsymbol{n}=0,45$ (gömbi részecskéknél 0,42), akkor a kioldódását a diffúzió kontrollálja (Fick diffúzió). Ezzel ellentétben, ha diffúziós-oldódási index értéke $0,45<\boldsymbol{n}<1,0$, akkor a kioldódás erózió kontrollált nem -Fick diffúziós folyamat ( $\mathrm{n}=1,0$ esetében már csak a Case II. (relaxációs) transzport a domináns).

A Weibull egyenlet egy általános empirikus modell, amely szinte minden oldódási görbére alkalmazható. Az egyenlet csak az oldatban lévő hatóanyag mennyiségét veszi figyelembe (14. egyenlet):

$$
\frac{c_{t}}{c_{0}}=1-e^{-\left(\frac{t-T}{a}\right)^{b}}
$$

ahol $\boldsymbol{c}_{\boldsymbol{t}}$ a kioldódott hatóanyag koncentrációja $\boldsymbol{t}$ időpillanatban, $\boldsymbol{c}_{\boldsymbol{0}}$ a felszabadult hatóanyag teljes koncentrációja, $\boldsymbol{T}$ a késleltetési idő a mérés kezdete és a hatóanyag 
felszabadulása között (legtöbb esetben $\mathrm{T}=0$ ), $\boldsymbol{a}$ egy idöfüggést leíró skálaparaméter és $\boldsymbol{b}$ az oldódási görbe alakját leíró paraméter (exponenciális: $\boldsymbol{b}=1$, szigmoid: $\boldsymbol{b}>1$, parabola: $\boldsymbol{b}<1$ ).

A Peppas-Shalin egyenletben külön szerepel a Fick diffúzió és a Case II relaxáció hozzájárulása a kioldódási folyamathoz (15. egyenlet):

$$
\frac{\mathrm{c}_{\mathrm{t}}}{\mathrm{c}_{0}}=\mathrm{k}_{1} \mathrm{t}^{\mathrm{m}}+\mathrm{k}_{2} \mathrm{t}^{2 \mathrm{~m}}
$$

ahol $\boldsymbol{c}_{\boldsymbol{t}}$ a kioldódott hatóanyag koncentrációja $\boldsymbol{t}$ időpillanatban, $\boldsymbol{c}_{\boldsymbol{0}}$ a hatóanyag kezdeti koncentrációja, $\boldsymbol{k}_{1}$ a Fick diffúziós hozzájárulás értéke, $\boldsymbol{k}_{2}$ a Case II relaxációs hozzájárulás értéke és $\boldsymbol{m}$ a diffúziós kitevő.

A modell alapján az $\boldsymbol{m}$ diffúziós kitevő megadja a kioldódás mechanizmusa (Fick diffúzió: gömb részecskéknél $m=0,43$; filmeknél $m=0,50$; henger alaknál $m=0,45$; Case II (relaxációs) transzport: gömb részecskéknél $\mathrm{m}=0,85$; filmeknél $\mathrm{m}=1,0$; henger alaknál $\mathrm{m}=$ 0,89; vegyes mechanizmus: gömb részecskéknél $0,43<\mathrm{m}<0,85$; filmeknél $0,5<\mathrm{m}<1,0$; henger alaknál $0,45<\mathrm{m}<0,89)$.

\subsubsection{Egyéb alkalmazott müszeres technikák}

A PLUR $\mathrm{cmc}$ értékét tenziometriás mérésekkel határoztuk meg. A vizsgálatokat egy automatizált, számítógép kontrollált és LabDesk ${ }^{\circledR}$ szoftverrel működő KRÜSS K100MK2 típusú univerzális felületi feszültségmérő készülékkel végeztük el $25 \pm 0,1{ }^{\circ} \mathrm{C}$ hőmérsékleten. A tenziometriás mérések során egy csiszolatlan optimálisan $0^{\circ}(\cos \theta=1)$ Milli-Q vízzel szembeni nedvesedési szöggel rendelkező platina lemezt (Wilhelmy lemezes módszer) felhasználva szemiempirikusan kiszámolhatjuk a felületi feszültséget a $\mathbf{1 6 .}$ egyenlet alapján:

$$
\gamma=\frac{\mathrm{F}}{\mathrm{L} \cos \theta}
$$

ahol $\boldsymbol{\gamma}$ a felületi feszültség, $\boldsymbol{F}$ a lemez kihúzásakor mért erő, $\boldsymbol{L}$ a lemez kerülete és $\boldsymbol{\theta}$ a peremszög (esetünkben $0^{\circ}$ ). A vizsgálatok alatt a platina lemezt $50 \mathrm{~mL}$ térfogatú, 1,6 $\mathrm{mM}$ koncentrációjú PLUR oldatba merítettük, majd az oldatot az alkalmazott közegtől függően 10 mL össztérfogatú nagytisztaságú Milli-Q vízzel vagy PBS oldattal 40 lépésben titráltuk. A titrálás a müszerhez tartozó automata bürettával történt. A felületi feszültség értékeket legalább 5-5 mérés átlagából határoztuk meg.

Az FT-IR, DSC, TG, DTA és in vitro kioldódási méréseknél felhasznált pormintákat fagyasztva szárítással (liofilizálással) állítottuk elő. Közvetlen az eljárás megkezdése előtt 
a mintákat cseppenként lefagyasztottuk folyékony nitrogénnel lehütött üvegben. Az oldószert 4 mbar nyomáson egy Christ Alpha 1-2 LD típusú fagyasztva szárító berendezéssel távolítottuk el. A PLA/PLGA részecskék esetében a minták fagyasztását $-80{ }^{\circ} \mathrm{C}$ és $-20{ }^{\circ} \mathrm{C}$ hőmérsékletű mélyhütőben is elvégeztük.

Az egyes oldatok és pufferek pontos $\mathrm{pH}$ értékét hidrogénion-szelektív üvegelektróddal felszerelt Mettler-Toledo FiveEasy ${ }^{\mathrm{TM}}$ müszerrel határoztuk meg. 


\section{Eredmények}

\subsection{A szintetizált PLA/PLGA polimerek karakterizálása és az előállított PLA/PLGA} részecskék jellemzése az oldószer, stabilizátor és hidrofilitási tulajdonságok függvényében

\subsubsection{A szintetizált PLA és PLGA polimerek karakterizálása}

Doktori munkám első lépéseként PLA/PLGA polimereket állítottunk elő gyürüfelnyitásos polimerizációs eljárással. A szintézist követően a kész termékek karakterizálására FT-IR spektroszkópiás vizsgálatokat végeztünk (11.A. ábra). A spektrumokon jól látható, hogy $1750 \mathrm{~cm}^{-1}$-nél a laktidra és a glikolidra is jellemző $\mathrm{C}=\mathrm{O}$ kettős kötés rezgési sávja mindegyik minta esetén megfigyelhető. Az ujjlenyomat tartományban $\left(v \leq 1500 \mathrm{~cm}^{-1}\right) 1180 \mathrm{~cm}^{-1}$ (kék szaggatott vonal) és $1080 \mathrm{~cm}^{-1}$ (piros szaggatott vonal) hullámszámoknál megjelenő rezgési sávok a polimerekre jellemző C-O észter kötésekhez rendelhetőek. A rögzített IR spektrumok az irodalmi adatokkal jó egyezésben vannak, így kijelenthetjük, hogy a ROP szintézis sikeresen végbement [81,82]. Az $1424 \mathrm{~cm}^{-}$ ${ }^{1}$-nél a glikolid $\mathrm{CH}_{2}$-re és a $1453 \mathrm{~cm}^{-1}$-nél a laktid $\mathrm{CH}_{3}$ csoportjának változására érzékeny rezgési sávokat (kék sávval jelölt) felhasználva, a csúcsok alatti integrál értékek arányából meghatároztuk a PLGA kopolimerekben lévő monomer arányokat. A számolásokhoz a 17. és 18. egyenleteket alkalmaztuk:

$$
\begin{aligned}
& \text { d,l-tejsav monomer }(\%)=\frac{\mathrm{CH}_{3} \text { integrál értéke }}{\mathrm{CH}_{3} \text { integrál értéke }+\mathrm{CH}_{2} \text { integrál értéke }} \times 100 \\
& \text { glikolsav monomer }(\%)=\frac{\mathrm{CH}_{2} \text { integrál értéke }}{\mathrm{CH}_{3} \text { integrál értéke+ } \mathrm{CH}_{2} \text { integrál értéke }} \times 100
\end{aligned}
$$

A számolt százalékos értékek alapján a PLGA65 $62 \pm 5 \%$ laktid és $38 \pm 6 \%$ glikolid, míg a PLGA75 $73 \pm 4 \%$ laktid és $27 \pm 3 \%$ glikolid monomerből épül fel, melyek a nominális $65 \%$ és $75 \%$ laktid tartalom értékekkel közel megegyeznek. A polimerek termikus sajátságait, az üvegesedési $\left(\mathrm{T}_{\mathrm{g}, \max }\right)$ és a degradációs $\left(\mathrm{T}_{\mathrm{d}, \max }\right)$ hőmérsékletét DSC mérésekkel határoztuk meg (11.B. ábra). Referenciaként a kereskedelemben kapható PLA/PLGA polimerek, a laktid és a glikolid termikus tulajdonságait is megvizsgáltuk. 

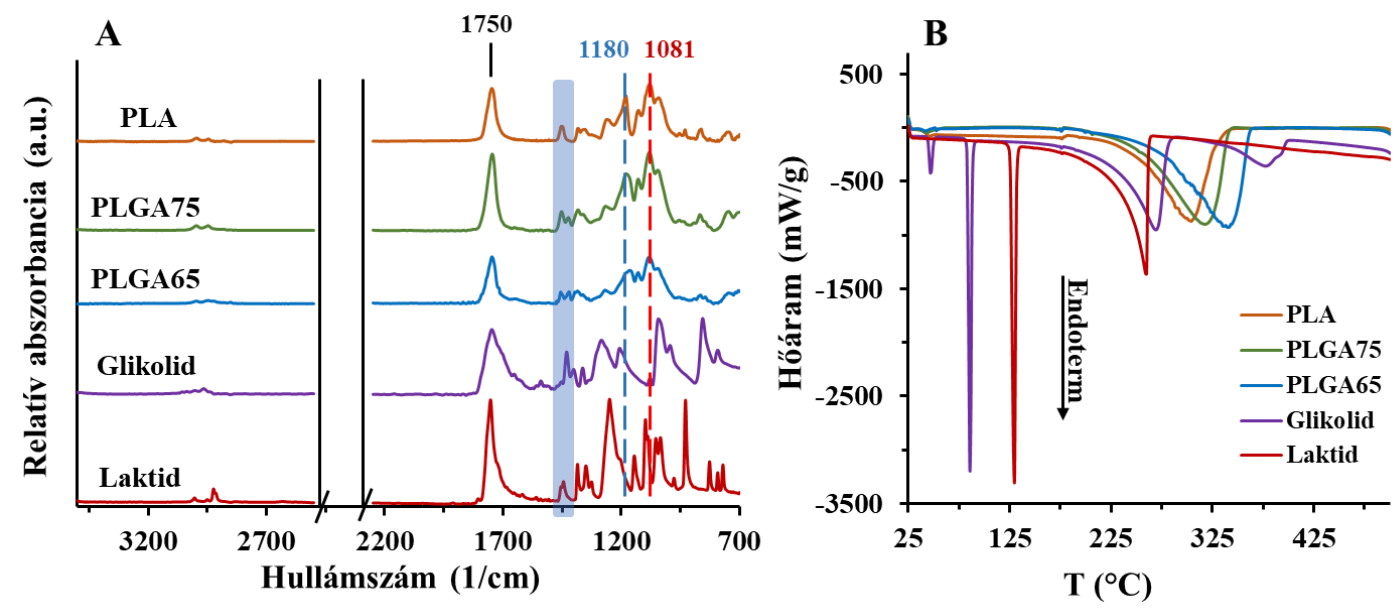

11. ábra: A PLA/PLGA polimerek és a ciklikus dimerek (A) FT-IR spektrumai és (B)

DSC görbéi

A laktid $130{ }^{\circ} \mathrm{C}$ (olvadáspont) és $260^{\circ} \mathrm{C}$ (degradációs hőmérséklet), illetve a glikolid $86^{\circ} \mathrm{C}$ (olvadáspont) és $269^{\circ} \mathrm{C}$ hőmérséklet értékeknél (degradációs hőmérséklet) megjelenő karakterisztikus endoterm csúcsai az egyes polimerek DSC görbéin nem figyelhetőek meg, ami arra utal, hogy számottevő mennyiségü szabad monomer nincs jelen a mintáinkban. A DSC görbéken megfigyelhető degradációs hőmérsékletek a PLA -tól kezdve $\left(\mathrm{T}_{\mathrm{d}, \max }=304\right.$ ${ }^{\circ} \mathrm{C}$ ) fokozatosan növekvő értéket mutatnak a kopolimerekben jelenlévő glikolid mennyiségének növelésével $\left(\mathrm{T}_{\mathrm{d}, \max }=317{ }^{\circ} \mathrm{C}(\mathrm{PLGA75}), \mathrm{T}_{\mathrm{d}, \max }=341{ }^{\circ} \mathrm{C}(\right.$ PLGA65)), amit feltételezhetően a makromolekulás láncban lévő hidrofil részek között megnövekedő intermolekuláris kölcsönhatások okoznak. A kereskedelemben kapható és az általunk szintetizált PLA/PLGA termikus sajátságai jelentős eltérést nem mutatnak (2. táblázat). A meghatározott üvegesedési hömérsékletek $42{ }^{\circ} \mathrm{C}$ (PLGA65), $45^{\circ} \mathrm{C}$ (PLGA75), $46{ }^{\circ} \mathrm{C}$ (PLA) értékeknek adódtak. Korábban G. Reich és kutatócsoportja a PLA/PLGA mikrorészecskék degradációs sajátságait vizsgálta PBS pufferben. Az általa, ugyanezen polimerekre, meghatározott üvegesedési hőmérsékletek az általunk mért értékekkel jó egyezést mutat $\left(\operatorname{PLA}\left(\mathrm{M}_{\mathrm{w}}=14500 \mathrm{Da}\right): \mathrm{T}_{\mathrm{g}}=48,2{ }^{\circ} \mathrm{C}, \operatorname{PLGA75}\left(\mathrm{M}_{\mathrm{w}}=66800 \mathrm{Da}\right): \mathrm{T}_{\mathrm{g}}=47,6{ }^{\circ} \mathrm{C}\right)$ [113].

Jól ismert, hogy a polimer alapú részecskék méretét jelentősen befolyásolja az egyes polimerek molekulatömege, mivel a nagyobb makromolekulák felhasználásával lényegesen nagyobb részecskék képződhetnek [84]. A polimerek jellemzéséhez hozzájárulva meghatároztuk az általunk elóállított polimerek átlagos molekulatömegét is, amit 0-20 $\mathrm{mg} / \mathrm{mL}$ 1,4-dioxános polimer oldatok DLS módszerrel történő vizsgálataiból definiáltunk (12. ábra). A Rayleigh-Gans-Debye modellel (1. egyenlet) meghatározott molekulatömegek és a második viriál együttható értékeket a 2. táblázatban összesítettük. 

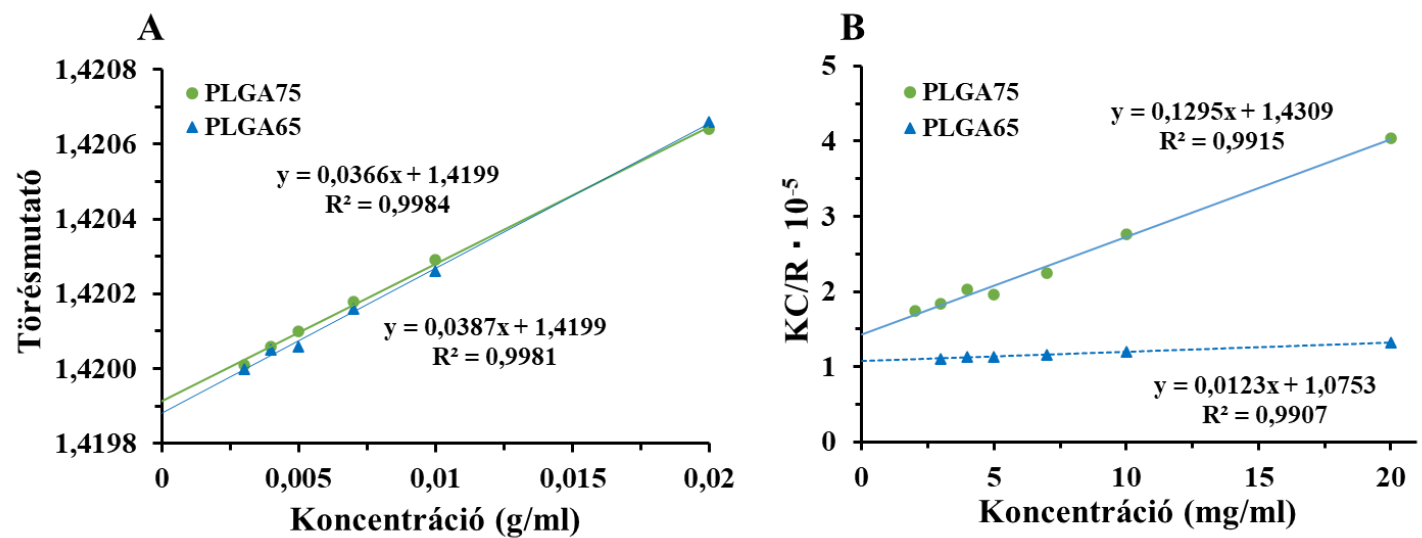

12. ábra: (A) A PLGA65 és a PLGA75 kopolimerek törésmutató értékei a koncentráció függvényében és (B) a Rayleigh-Gans-Debye egyenlet (1. egyenlet) grafikus ábrázolása

2. táblázat: A DSC és a DLS mérésekkel meghatározott üvegesedési hőmérséklet ( $\left.T_{\mathrm{g}, \max }\right)$, degradációs hőmérséklet $\left(\mathrm{T}_{\mathrm{d}, \max }\right)$, átlagos molekulatömeg és második viriál együttható értékek a szintetizált, illetve a kereskedelmi forgalomban kapható PLA/PLGA esetén

\begin{tabular}{|c|c|c|c|c|c|}
\hline & polimer & $\begin{array}{c}T_{g, \max } \\
\left(C^{\circ}\right)\end{array}$ & $\begin{array}{l}T_{d, \max } \\
\left(C^{\circ}\right)\end{array}$ & $\begin{array}{l}\mathrm{M}_{\mathrm{W}} \\
\text { (Da) }\end{array}$ & $\begin{array}{c}\mathrm{A}_{2} \\
\left(\mathrm{~mL} \cdot \mathrm{mol} / \mathrm{g}^{2}\right)\end{array}$ \\
\hline \multirow{3}{*}{ 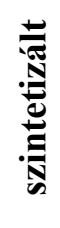 } & PLGA65 & 42 & 341 & $93000 \pm 1000$ & $6,15 \mathrm{E}-05 \pm 5,17 \mathrm{E}-06$ \\
\hline & PLGA75 & 45 & 317 & $69900 \pm 4000$ & $6,48 \mathrm{E}-04 \pm 3,80 \mathrm{E}-05$ \\
\hline & PLA & 46 & 304 & $72200 \pm 15000$ & $2,70 \mathrm{E}-04 \pm 3,29 \mathrm{E}-04$ \\
\hline \multirow{3}{*}{ 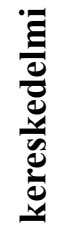 } & PLGA65 $^{\#}$ & 40 & 340 & $40000-75000$ & - \\
\hline & PLGA75 $^{\#}$ & 44 & 315 & $66000-104000$ & - \\
\hline & $\mathbf{P L A}^{\#}$ & 33 & 302 & $\approx 250000$ & - \\
\hline
\end{tabular}

\# a molekulatömeg értékek a Sigma-Aldrich anyagbiztonsági adatlapja szerint

A vizsgálatok elött meghatározott törésmutató értékek koncentráció függése (12.A. ábra) esetében az illesztett egyenesek nagy hasonlóságot mutatnak. A DLS mérések révén kapott eredményeink alapján, az irodalomban ROP módszerrel előállított PLA/PLGA származékokhoz képest, viszonylag alacsony, $\mathrm{M}_{\mathrm{w}}<100 \mathrm{kDa}$ alatti molekulatömegü polimereket állítottunk elő [114], amelyek közül a legnagyobb molekulatömeggel a PLGA65 rendelkezik (92000 \pm 1000 Da). A Rayleigh-Gans-Debye modellel meghatározott második viriál együttható a vizsgált 1,4-dioxános közegben a PLGA65 esetében a legkisebb, ami megerősíti, hogy a vártnak megfelelően a leghidrofilebb sajátsággal a PLGA65 rendelkezik. 
Az átlagos molekulatömeg értékek DLS technikával történő meghatározása mellett a polimerek méreteloszlásának igazolására turbidimetriás méréseket is végeztünk (13. ábra). A precipitációs titrálások során a PLGA kopolimereket 1,4-dioxánban oldottuk, majd kicsapószerként nagy tisztaságú Milli-Q vizet használtunk. A 13. ábrán látható görbék alapján a PLGA75 esetében $\mathrm{V}_{\text {víz }} / \mathrm{V}_{\text {össz }}=15,7 \%$, míg a PLGA65-tartalmú mintáknál $\mathrm{V}_{\text {viz }} / \mathrm{V}_{\text {össz }}=14,6 \%$ víztartalom esetén indul a csapadékképződés. A kereskedelemben kapható polimereknél ugyanezen értékek: $\mathrm{V}_{\text {víz }} / \mathrm{V}_{\text {össz }}=14,7 \%\left(\right.$ PLGA75; $\mathrm{M}_{\mathrm{w}}=(66000-$ 104000) Da) és $V_{\text {viz }} / V_{\text {össz }}=17,1 \%\left(P L G A 65 ; M_{w}=(40000-75000)\right.$ Da). Megállapíthatjuk tehát, hogy az általunk szintetizált PLGA75 kisebb, míg a PLGA65 nagyobb átlagos molekulatömeggel rendelkezik a referenciaként alkalmazott polimerekhez képest, mely jó egyezésben van a DLS méréseknél kapott eredményeinkkel. A titrálási görbék lefutása a szintetizált polimereknél meredekebben változik, ami alátámasztja, hogy az általunk előállított PLA/PLGA polimerek szükebb molekulatömeg eloszlással bírnak, mely kedvező monodiszperz kolloid részecskék méretszabályozott előállításához.
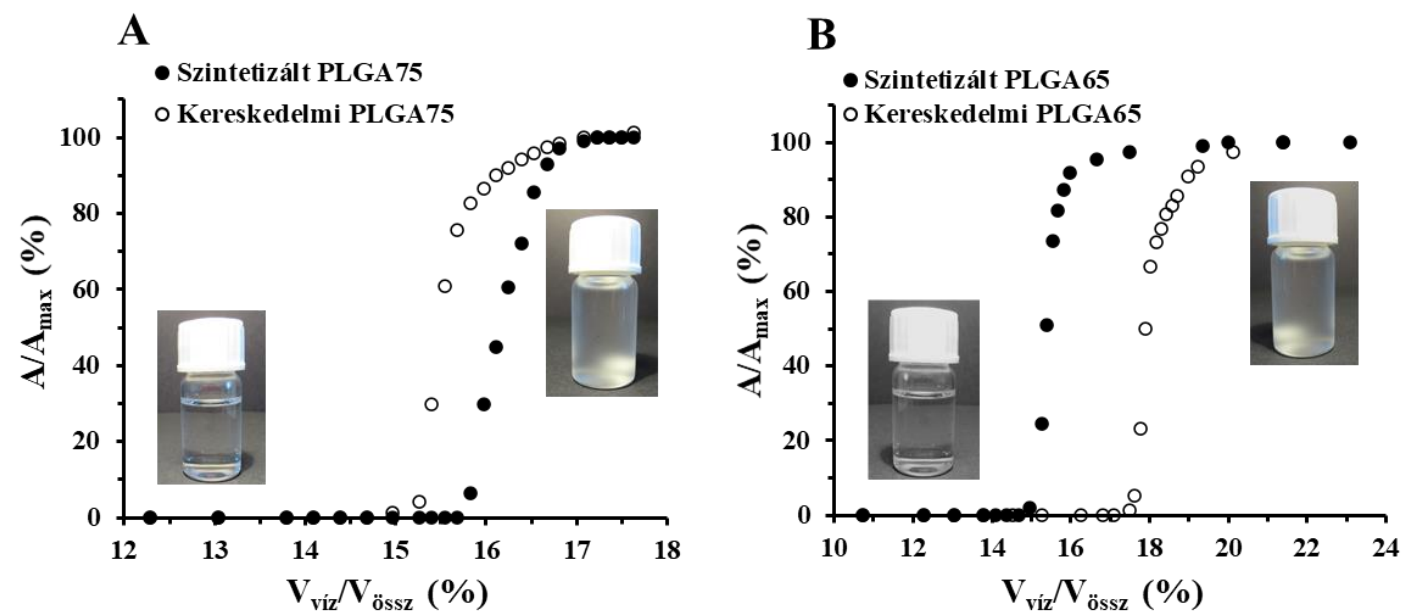

13. ábra: 1,4-dioxánban oldott (A) PLGA75 és (B) PLGA65 precipitációs görbéi (titrálószer: Milli-Q víz, titrálandó oldat: $\mathrm{V}=5 \mathrm{~mL}, \mathrm{CPLA}_{\mathrm{PLG}}=5 \mathrm{mg} / \mathrm{mL}$ )

A különböző laktid:glikolid arányú polimerek hidrofilitásának összehasonlítása érdekében peremszög vizsgálatokat végeztünk el. A polimer felületeken felvett peremszög értékeket és a cseppekről készült képeket a 14. ábrán mutatjuk be. 


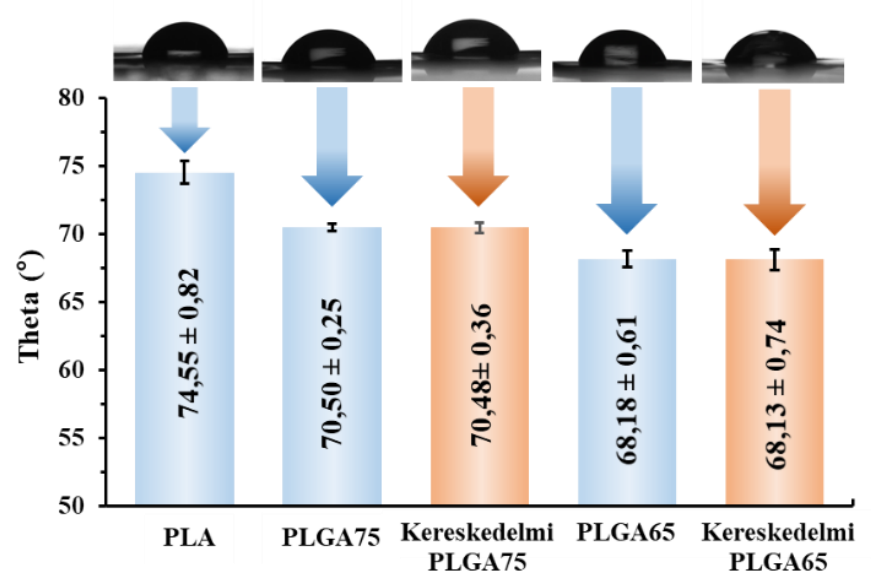

14. ábra: A PLA/PLGA polimerek peremszög értékei a felületre cseppentett 10 - $10 \mu \mathrm{L}$ térfogatú vízcseppekre meghatározva

A meghatározott peremszögek a PLA makromolekulától kezdve fokozatosan csökken $\sim 74,5^{\circ}$-tól (PLA) 68,2 ${ }^{\circ}$-ig (PLGA65) a glikolid mennyiségének növekedésével, ami igazolja, hogy a szintetizált polimerek hidrofilitása szisztematikusan változik a laktid:glikolid aránnyal. A mérések során a kereskedelmi forgalomban kapható PLGA75 és 65 nedvesedési tulajdonságait is meghatároztuk, ahol a PLGA75 esetén 70,48 $\pm 0,36^{\circ}$ és PLGA65 vonatkozásában 68,13 $\pm 0,74^{\circ}$ értékeket kaptunk. Az eredményeket összevetve megállapítható, hogy az általunk előállított szűkebb méreteloszlású és kissé eltérő molekulatömegü polimerek a kereskedelmi forgalomban kaphatókkal tökéletesen megegyező nedvesedési tulajdonságokkal rendelkeznek.

\subsubsection{Hatóanyag nélküli PLA/PLGA részecskék jellemzése}

Az előállított PLA, PLGA65 és PLGA75 polimerek karakterizálása után nanoprecipitációs módszerrel kíséreltünk meg a polimerekből kolloid részecskéket előállítani. Ahogy az Irodalmi áttekintésben részleteztük, elhanyagolható azon irodalmi hivatkozások száma, melyek az alkalmazott oldószer, a stabilizátor és az eltérő hidrofilitású polimerek együttes hatását elemzik a részecskék szabályozható előállítására vonatkozóan. Vizsgálatainkkal ezen hatások tanulmányozását kívántuk értelmezni. Első lépésben a képződő részecskék méretét határoztuk meg fényszórás mérésekkel (3. táblázat). Az eredményekből jól látható, hogy függetlenül az alkalmazott stabilizátor típusától és a szerves oldószer jellegétől, a hidrofilebb karakterű polimerek alkalmazása esetén mindig kisebb részecskeméret érhető el. 
3. táblázat: Nanoprecipitációs eljárással elöállított PLA/PLGA részecskék DLS módszerrel meghatározott hidrodinamikai átmérő $\left(\mathrm{d}_{\mathrm{DLS}}\right)$ és polidiszperzitási index $(\mathrm{PI})$ értékei

\begin{tabular}{|c|c|c|c|c|c|c|c|}
\hline & \multicolumn{3}{|c|}{ CTAB } & \multicolumn{2}{|c|}{ PVA } & \multicolumn{2}{|c|}{ Pluronic F127 } \\
\hline & polimer & PI & $\begin{array}{c}\mathbf{d}_{\mathrm{DLS}} \pm \mathbf{S D}^{\#} \\
(\mathbf{n m})\end{array}$ & PI & $\begin{array}{c}\mathbf{d}_{\mathrm{DLS}} \pm \mathbf{S D}^{\#} \\
(\mathbf{n m})\end{array}$ & PI & $\begin{array}{c}\mathbf{d}_{\mathrm{DLS}} \pm \mathbf{S D}^{\ddagger} \\
(\mathbf{n m})\end{array}$ \\
\hline \multirow{3}{*}{$\stackrel{\Xi}{0}$} & PLGA65 & $0,65 \pm 0,05$ & $228 \pm 18$ & $0,16 \pm 0,07$ & $211 \pm 28$ & $0,11 \pm 0,07$ & $186 \pm 32$ \\
\hline & PLGA75 & $0,47 \pm 0,02$ & $261 \pm 16$ & $0,06 \pm 0,04$ & $221 \pm 63$ & $0,10 \pm 0,01$ & $180 \pm 33$ \\
\hline & PLA & $0,56 \pm 0,10$ & $355 \pm 27$ & $0,17 \pm 0,03$ & $243 \pm 72$ & $0,05 \pm 0,05$ & $190 \pm 44$ \\
\hline \multirow{3}{*}{ 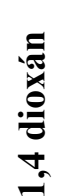 } & PLGA65 & $0,57 \pm 0,08$ & $239 \pm 27$ & $0,08 \pm 0,03$ & $260 \pm 57$ & $0,17 \pm 0,04$ & $232 \pm 64$ \\
\hline & PLGA75 & $0,48 \pm 0,04$ & $266 \pm 23$ & $0,09 \pm 0,05$ & $268 \pm 51$ & $0,09 \pm 0,02$ & $236 \pm 53$ \\
\hline & PLA & $0,57 \pm 0,03$ & $381 \pm 36$ & $0,13 \pm 0,06$ & $271 \pm 58$ & $0,09 \pm 0,04$ & $260 \pm 61$ \\
\hline
\end{tabular}

\# A csúcsmaximum kísérleti hibája 2,5\% alatti

A felhasznált szerves oldószereket összehasonlítva megállapíthatjuk, hogy az acetonhoz $\left(\mathrm{T}_{\mathrm{f}}=56{ }^{\circ} \mathrm{C} ; \gamma=25,2 \mathrm{mN} / \mathrm{m}\left(20{ }^{\circ} \mathrm{C}\right) ; \rho=0,784 \mathrm{~g} / \mathrm{cm}^{3}\right)$ képest a magasabb sürüséggel, felületi feszültséggel és forrásponttal rendelkező 1,4-dioxán esetén $\left(\mathrm{T}_{\mathrm{f}}=101{ }^{\circ} \mathrm{C}\right.$; $\left.\gamma=33,0 \mathrm{mN} / \mathrm{m}\left(20{ }^{\circ} \mathrm{C}\right) ; \rho=1,03 \mathrm{~g} / \mathrm{cm}^{3}\right)$ átlagosan $10-70 \mathrm{~nm}$-rel nagyobb hidrodinamikai átmérővel rendelkező részecskék képződnek, amelyek közül a legkisebb mérettel a PLGA65 polimer és PLUR stabilizátor együttes alkalmazása mellett előállított részecskék rendelkeznek $\left(\mathrm{d}_{\mathrm{DLS}}=232 \mathrm{~nm}\right)$. A stabilizátorok hatását tanulmányozva a legnagyobb részecskeméret és polidiszperzitási index értékeket a pozitív töltésü CTAB esetén, míg a legkisebb részecske méretet a PLUR stabilizátor és aceton oldószer alkalmazásával értük el $\left(\mathrm{d}_{\mathrm{DLS}} \approx 186 \mathrm{~nm}(\mathrm{PLGA65}), \mathrm{d}_{\mathrm{DLS}} \approx 180 \mathrm{~nm}\left(\right.\right.$ PLGA75), $\mathrm{d}_{\mathrm{DLS}} \approx 190 \mathrm{~nm}$ (PLA)). A PVA felhasználásával előállított rendszerek polidiszperzitása a PLUR-tartalmú mintákkal összevethető, viszont a nagyobb molekulatömegnek köszönhetően (PVA: $\mathrm{M}_{\mathrm{w}} \sim 72000 \mathrm{Da}$, PLUR: $\left.\mathrm{M}_{\mathrm{w}} \sim 12600 \mathrm{Da}\right)$ a részecskék hidrodinamikai átmérője nagyobb lesz. Ezek alapján kijelenthető, hogy a stabilizátorok töltése és molekulatömege a PLA/PLGA alapú részecskék méretét és polidiszperzitását jelentősen befolyásolja.

A részecskék stabilitásának meghatározásához ל-potenciál méréseket is végeztünk. Első lépésben az aceton közegű és különböző stabilizátorokkal elkészített PLGA75 alapú kolloid részecskéket $\zeta$-potenciál értékeit értelmeztük (15. ábra). A méréseket tisztítás előtt és után is elvégeztük. A tisztítás előtti mintáknál átlagosan $\zeta=82,3 \pm 1,4 \mathrm{mV}(\mathrm{CTAB}), \zeta=$ $11,3 \pm 2,7 \mathrm{mV}$ (PVA) és $\zeta=-22,4 \pm 1,5 \mathrm{mV}$ (PLUR), míg a tisztítás után $\zeta=-53,4 \pm 0,7 \mathrm{mV}$ 
(CTAB), $\zeta=-72,3 \pm 0,6 \mathrm{mV}$ (PVA) és $\zeta=-87,6 \pm 1,9 \mathrm{mV}$ (PLUR) értékeket kaptunk. Megállapíthatjuk, hogy a feleslegben lévő stabilizátorok eltávolítása elengedhetetlen a megfelelő kolloid stabilitással rendelkező gyógyszerhordozó rendszerek előállításához. A 15.B. ábrán látható, hogy a legnagyobb stabilitás a PLUR alkalmazása esetén figyelhető meg. A kísérletsorozat következő lépésében a PLUR stabilizátor és acetonos oldószer

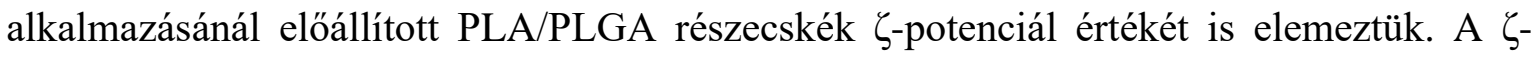
potenciál értékek tisztítás előtt $\zeta=-21,4 \pm 1,1 \mathrm{mV}$ (PLGA65), $\zeta=-22,4 \pm 1,5 \mathrm{mV}$ (PLGA75) és $\zeta=-23,1 \pm 2,0 \mathrm{mV}$ (PLA) értéknek, míg tisztítás után $\zeta=-85,7 \pm 1,8 \mathrm{mV}$ (PLA65), $\zeta=$ $87,6 \pm 1,9 \mathrm{mV}$ (PLGA75) és $\zeta=-82,2 \pm 1,2 \mathrm{mV}$ (PLA) adódtak. A PLA/PLGA részecskék között jelentős változás nem figyelhető meg, tehát a laktid:glikolid arányok szisztematikus változtatásával kialakított eltérő hidrofilitási tulajdonságok a részecskék stabilitására meghatározó hatással nem bírnak.
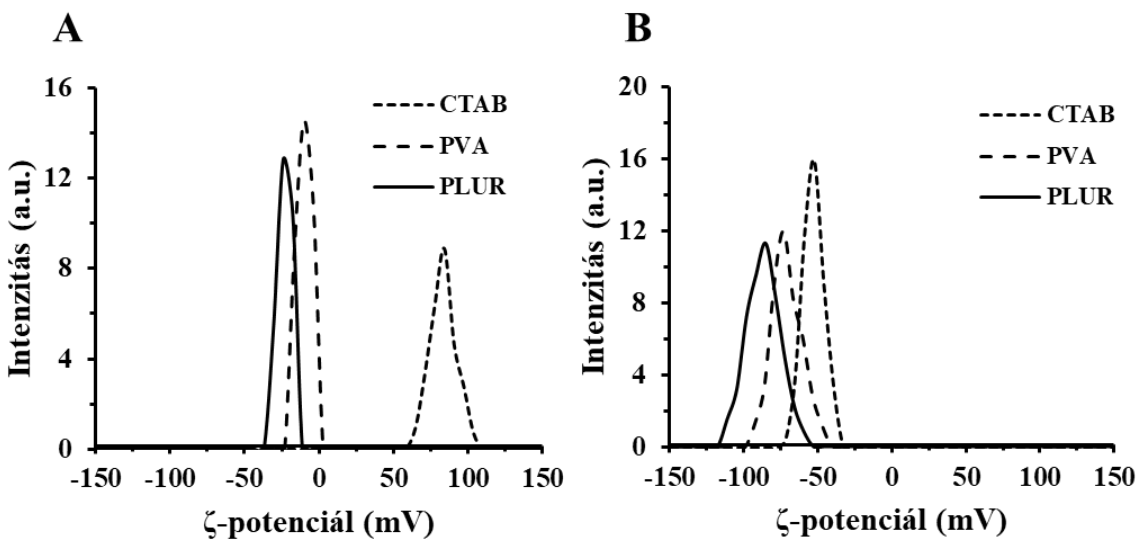

15. ábra: A különböző stabilizátorok mellett előállított PLGA75 részecskék reprezentatív $\zeta$-potenciál értékei tisztítás $(\mathbf{A})$ előtt és $(\mathbf{B})$ után (szerves fázis: $\mathrm{V}=1,5 \mathrm{~mL}, \mathrm{c}_{\mathrm{PLGA75}}=10$ $\mathrm{mg} / \mathrm{mL}$, vizes fázis: $\mathrm{V}=15 \mathrm{~mL}, \mathrm{c}_{\text {stabilizátor }}=0,1 \mathrm{mg} / \mathrm{mL}$ )

A kialakuló részecskék morfológiáját, méretét/méreteloszlását és szerkezetét TEM felvételekkel határoztuk meg. A 16. ábra példaként a PLA alapú részecskék elektronmikroszkópos képeit mutatja mindhárom stabilizátor alkalmazása esetén. A TEM képek alapján megállapítható, hogy a CTAB esetén nagyméretű részecskék mellett aggregátumok is képződnek, melyet a részecskék stabilitás vizsgálatakor meghatározott $\zeta$ potenciál értékek is alátámasztanak. A felvételeken jól látható, hogy a PVA és PLUR alkalmazásával a részecskék mérettartománya PVA: $220 \pm 40 \mathrm{~nm}$, PLUR: $170 \pm 24 \mathrm{~nm}$ között változik, melyek közül a PLUR esetében figyelhető meg monodiszperzebb rendszer képződése. 


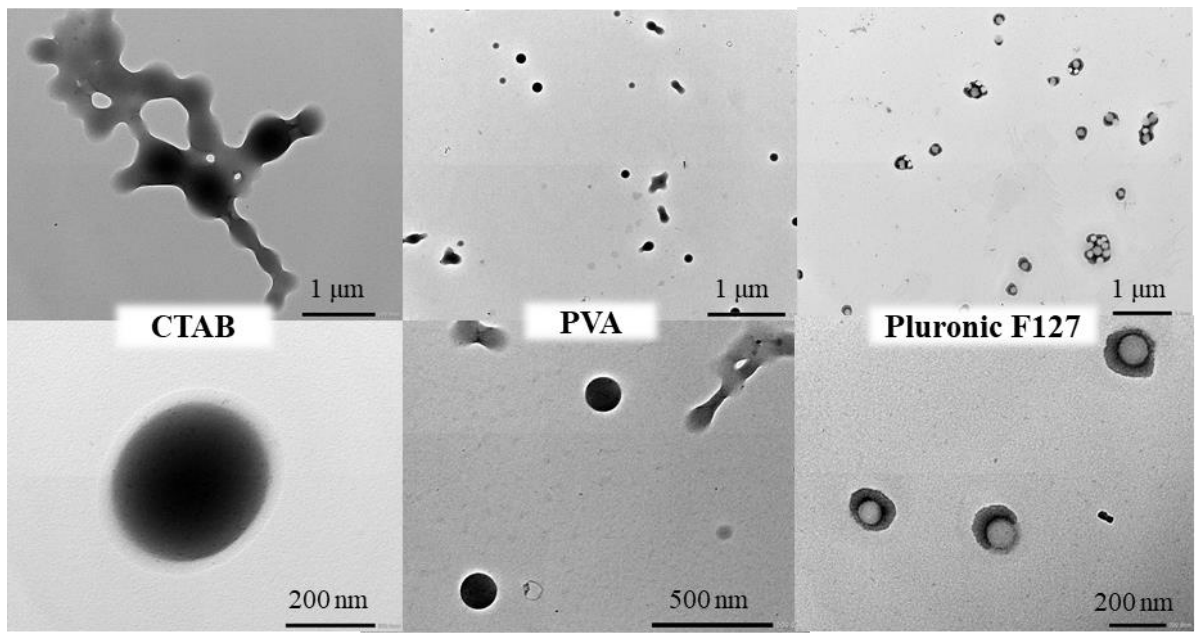

16. ábra: Különböző stabilizátorok felhasználásával előállított PLA részecskék

reprezentatív TEM felvételei eltérő nagyítások mellett (szerves fázis: aceton, $\mathrm{C}_{\mathrm{PLA}}=10$ $\mathrm{mg} / \mathrm{mL}, \mathrm{V}=1,5 \mathrm{~mL}$, vizes fázis: $\mathrm{c}_{\text {stabilizátor }}=0,1 \mathrm{mg} / \mathrm{mL}, \mathrm{V}=15 \mathrm{~mL}$ )

\subsubsection{Hatóanyag-tartalmú PLA/PLGA részecskék jellemzése}

A továbbiakban az előző fejezetben jellemzett aceton/víz alkalmazása mellett PLUR stabilizátorral előállított PLA/PLGA75/PLGA65 részecskék kapszulázási tulajdonságait térképeztük fel különböző hidrofilitási tulajdonsággal rendelkező (modell)hatóanyagok (TPGS, KP, TP) felhasználásával. A TP a nyolc különböző szerkezetü E- vitamin származék közül biológiailag a legaktívabb [115,116], melyet antioxidáns jellege alkalmassá teszi oxidatív stressz hatásainak csökkentésére elősegítve a szív és érrendszeri betegségek, rák vagy érelmeszesedés megelőzését. Ennek egy hidrofilebb, észteres származéka a stabilizátorként is alkalmazható TPGS. A KP egy elterjedten alkalmazott nem-szteroid gyulladáscsökkentő gyógyszerszármazék [117]. A kísérleti körülményekben részletezett előállítási protokollok alapján a képződő részecskék méretét és méreteloszlási tulajdonságait tanulmányoztuk első lépésben. A méreteloszlási görbék alapján megállapítottuk, hogy a hatóanyagok hidrofilitás csökkenésével (TPGS $>\mathrm{KP}>\mathrm{TP}$ ) a részecskék hidrodinamikai átmérője szisztematikusan nő (M46. ábra, 4. táblázat). Ezzel ellentétben ugyanazon hatóanyag esetén a polimerek laktid:glikolid arányának változtatása nincs számottevő hatással a méretre. A hatóanyag nélküli minták monodiszperzebb méreteloszlással rendelkeznek, mint a hatóanyag-tartalmúak.

A hatóanyag-tartalmú részecskék stabilitását is tanulmányoztuk a tisztítási lépések előtt és után. Megállapítottuk, hogy a hatóanyag jelenléte nem változtatja meg a mért $\zeta$ potenciál értékeket. A mérésekkel alapján a tisztítás mindenképpen elengedhetetlen a részecskék megfelelő stabilitásának eléréséhez, melyet a példaként bemutatott PLGA75 
alapú részecskék $\zeta$-potenciál értékei is alátámasztanak (tisztítás elött: $\zeta=-22,4 \pm 1,5 \mathrm{mV}$ (hatóanyag nélkül) $\zeta=-19,6 \pm 1,1 \mathrm{mV}$ (TPGS), $\zeta=-19,4 \pm 2,8 \mathrm{mV}$ (KP) és $\zeta=-24,0 \pm 0,7$ $\mathrm{mV}(\mathrm{TP})$, tisztitás után $\zeta=-87,6 \pm 1,9 \mathrm{mV}$ (hatóanyag nélkül), $\zeta=-87,5 \pm 3,0 \mathrm{mV}$ (TPGS), $\zeta=-62,5 \pm 2,1 \mathrm{mV}(\mathrm{KP})$ és $\zeta=-62,0 \pm 2,5 \mathrm{mV}(\mathrm{TP}))$. A legnagyobb $\zeta$-potenciál érték a TPGS esetén figyelhető meg, míg a legrosszabb vízoldékonyságú vegyületeket tartalmazó részecskék esetén a mért értékek kisebbnek adódnak, mely eltérő szerkezetü részecskék képződésére utalhat.

4. táblázat: A PLUR -stabilizált hatóanyag-tartalmú PLA/PLGA részecskék átlagos részecske átmérői, a polidiszperzitási indexek és a kapszulázási hatékonyságok

\begin{tabular}{ccccccc}
\hline polimer & hatóanyag & PI & $\begin{array}{c}\mathbf{d}_{\text {DLS }} \pm \mathbf{S D}^{\#} \\
(\mathbf{n m})\end{array}$ & $\begin{array}{c}\mathbf{d}_{\text {TEM }} \pm \mathbf{S D} \\
(\mathbf{n m})\end{array}$ & $\begin{array}{c}\text { EE } \\
(\boldsymbol{\%})\end{array}$ & $\begin{array}{c}\text { DL } \\
(\boldsymbol{\%})\end{array}$ \\
\hline \multirow{2}{*}{ PLGA65 } & - & $0,11 \pm 0,07$ & $186 \pm 32$ & $164 \pm 51$ & - & - \\
& TPGS & $0,12 \pm 0,03$ & $178 \pm 48$ & $159 \pm 63$ & 11,34 & 3,78 \\
& KP & $0,14 \pm 0,04$ & $216 \pm 62$ & $204 \pm 71$ & 13,21 & 4,40 \\
& TP & $0,23 \pm 0,03$ & $253 \pm 52$ & $238 \pm 59$ & 88,25 & 29,41 \\
\hline \multirow{2}{*}{ PLGA75 } & - & $0,10 \pm 0,01$ & $180 \pm 33$ & $172 \pm 49$ & - & - \\
& TPGS & $0,07 \pm 0,04$ & $173 \pm 47$ & $160 \pm 56$ & 6,39 & 2,13 \\
& KP & $0,07 \pm 0,01$ & $207 \pm 42$ & $193 \pm 69$ & 7,91 & 2,64 \\
PLA & TP & $0,19 \pm 0,05$ & $257 \pm 75$ & $238 \pm 62$ & 90,28 & 30,09 \\
\hline & - & $0,05 \pm 0,05$ & $190 \pm 36$ & $183 \pm 57$ & - & - \\
& TPGS & $0,13 \pm 0,05$ & $195 \pm 64$ & $190 \pm 76$ & 6,88 & 2,29 \\
& KP & $0,09 \pm 0,06$ & $225 \pm 48$ & $211 \pm 64$ & 11,29 & 3,76 \\
& TP & $0,12 \pm 0,05$ & $257 \pm 73$ & $236 \pm 77$ & 69,07 & 23,02 \\
\hline
\end{tabular}

\# A csúcsmaximum kísérleti hibája $4 \%$ alatti

A részecskék szerkezetét és méretét a rögzített TEM képek alapján is meghatároztuk (17. ábra). Az elektronmikroszkópos felvételekről meghatározott átlagos átmérők a hidrodinamikai átmérőkhöz képest 10-20 nm -rel kisebb értéket mutattak, mely a vártnak megfelelö. A DLS mérésekkel összhangban a legnagyobb részecskeméretet itt is a TPtartalmú PLA/PLGA részecskéknél határoztuk meg.

A rögzített TEM felvételeket tanulmányozva egyértelműen kijelenthető, hogy míg a TPGS- és a KP- tartalmú részecskéknél homogén, addig a TP alkalmazása esetén egy jól definiált mag-héj struktúra kialakulása fedezhető fel, amelyet a polimerekben lévő laktid:glikolid arányok változtatása jelentős mértékben nem befolyásol. A mag-héj szerkezet előnye, hogy ily módon a TP kioldódása kontrollálhatóbbá válik, mindezek mellett 
biohasznosulása és stabilitása is megnő, ami a lipofil gyógyszerszármazékoknál nagy szereppel bírhat [118]. A részecskék szerkezeti sajátságait nézve a nanoprecipitációnál a mag-héj szerkezet kialakulása csak nagyon hidrofób hatóanyagok esetében valósulhat meg $(K P: \log \mathrm{P}=2,71[119] ; T P: \log \mathrm{P}=12,2$ [120]), ahol lehetőség adódik a polimer láncok hidrofób részeinek hatóanyag körüli csoportosulására. Hidrofilebb gyógyszerszármazékoknál, esetünkben a KP, a precipitáció mértéke (pl. a kicsapódott hatóanyag mennyisége) jelentősen eltérhet, ami csökkenti a fentebb említett mag-héj struktúra kialakulásának lehetőségét.

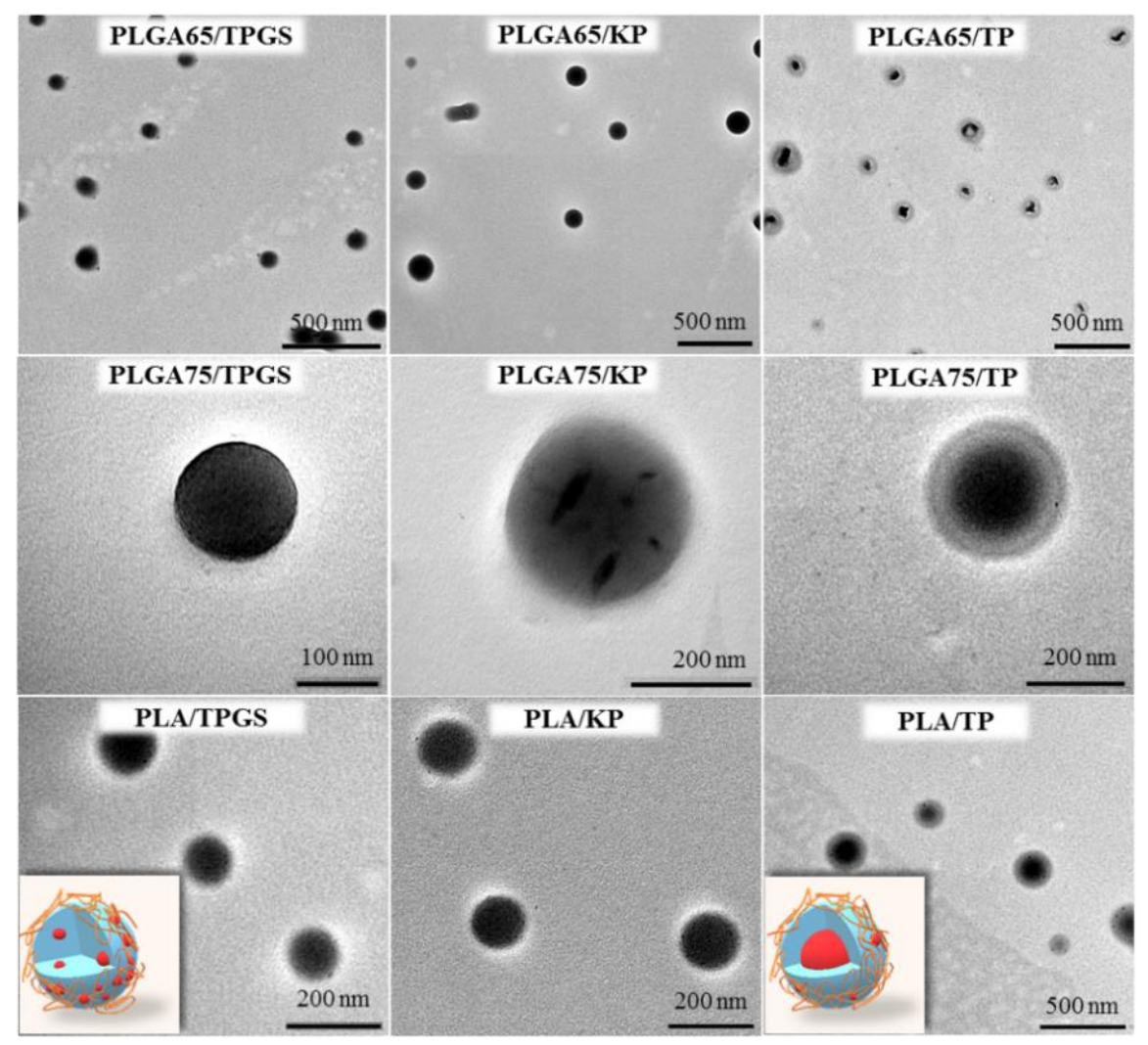

17. ábra: Nanoprecipitációs eljárással előállított, hatóanyag-tartalmú PLA és PLGA részecskék TEM képei és a feltételezhető szerkezet sematikus (nem méretarányos) ábrái (szerves fázis: $\mathrm{c}_{\mathrm{PLA} / \mathrm{PLGA}}=10 \mathrm{mg} / \mathrm{mL}, \mathrm{V}=1,5 \mathrm{~mL}$; vizes fázis: $\mathrm{C}_{\mathrm{PLUR}}=0,1 \mathrm{mg} / \mathrm{mL}, \mathrm{V}=15$

$$
\mathrm{mL} ; \mathrm{m}_{\text {hatóanyag }}=7,5 \mathrm{mg} \text { ) }
$$

A kapszulázási hatékonyságok meghatározását spektrofotometriás módszer segítségével kiviteleztük. A részecskékbe juttatott hatóanyag mennyiségeket a M47. ábráján látható kalibrációs egyenesek alapján állapítottuk meg. A PLA/PLGA kapszulázási hatékonyságát megvizsgálva a legkisebb értéket a TPGS esetén (6-11 \%), míg a legnagyobbat a TP vonatkozásában (70-90 \%) értük el (4. táblázat). A TP hatóanyagnál 
megfigyelt kimagasló kapszulázási hatékonyságnak köszönhető a korábban megállapított nagymértékü részecskeméret növekedés is. A nanoprecipitációs módszernél a hidrofób hatóanyagok PLGA mátrixba történő juttatása nagyobb hatékonysággal valósítható meg [89], amit esetünkben a TP és a PLA/PLGA erős hidrofób jellege tovább erősít. A KP vonatkozásában, a kezdetben vizes fázisban oldott TPGS vegyülethez hasonlóan, alacsony hatóanyag bevitelt figyeltünk meg. Ebben az esetben az említett hatóanyagok nagyrésze feltételezhetően főleg a részecskék felületén homogénen helyezkedik el, amit a ל-potenciál értékek is megerősítenek (17. ábra, sematikus kép). A PLA/PLGA hordozókat nézve egyértelmüen kijelenthető, hogy a hidrofilebb hordozók a TP hatóanyagnál nagyobb kapszulázási hatékonysággal rendelkeznek, így a glikolid arányának növelésével a hatóanyag hordozóba való vitele tovább növelhető. Ennek legfőbb oka lehet, hogy a hidrofilitás változásával a polimerek kicsapódási folyamatai is lassulhatnak, ami elősegítheti a TP mag kialakulásának lehetőségét, így a kapszulázási hatékonyság növekedését.

\subsection{Mag-héj szerkezetü TP-tartalmú PLA/PLGA részecskék előállítási protokolljának optimalizálása és szerkezeti jellemzésük}

5.2.1. Nanoprecipitációs technikával elöállitott TP- tartalmú PLA/PLGA részecskék koncentráció függő elöállítási protokolljának optimalizálása

A hidrofób TP kapszulázásával foglalkozó tudományos publikációkban nagyrészt emulziós-oldószer elpárologtatáson alapuló módszert használnak a nevezett hatóanyag polimer alapú mátrixba viteléhez [116,121-124], amely esetben csak homogén részecske szerkezet kialakulása figyelhető meg. A mérések során alkalmazott polimerek, hatóanyag és stabilizátor koncentrációjának befolyását kevésbé vizsgálták. C. Quintero és munkatársai poli( $N$-izopropil-akrilamid)-poli( $\varepsilon$-kaprolakton)- poli( $N$-izopropil-akrilamid) (PNIPAM- $b$ PCL-b-PNIPAM) triblokk kopolimerekbe kapszuláztak már TP molekulákat nanoprecipitációs módszerrel mag-héj struktúra kialakulása mellett, ahol azonban főként a hőmérséklet és a kopolimert felépítő monomerek mólarányainak a részecskék méretére, hőérzékeny viselkedésére, szerkezetére és a hatóanyag kioldódásra gyakorolt hatását tanulmányozták [125]. Mindezek függvényében, további munkánk során a nanoprecipitációs módszerrel előállított PLA/PLGA alapú TP-tartalmú mag-héj struktúrával rendelkező részecskék sajátságainak (méret, szerkezet, kapszulázási hatékonyság stb.) változását határoztuk meg a komponens koncentrációk szisztematikus változtatásának függvényében, hogy átfogó képet kapjunk a jól definiált mag-héj szerkezet kialakulásának feltételeiről. 
Ehhez az 5.1.3. alfejezetben már ismertetett TP- tartalmú PLA alapú részecskék előállítási protokollját optimalizáltuk. Az 5. táblázat jól összefoglalja, hogy a hordozó, a stabilizátor és a hatóanyag vonatkozásában milyen koncentráció értékek beállítása mellett végeztük el reproduktív módon a részecskék előállítását nanoprecipitációs módszerrel. A komponens koncentrációk részecskék méretére és szerkezetére gyakorolt hatásának követése érdekében a koncentrációk közül minden esetben csak egy paramétert változtattunk. A kapszulázási hatékonyság értékeket a M47.C. ábrája alapján állapítottuk meg. A PLA koncentráció függésével kapcsolatos vizsgálatok eredményeként megállapítható, hogy a részecskék hidrodinamikai átmérője $\sim 120 \mathrm{~nm}$-töl $\left(\mathrm{CPLA}_{\mathrm{PLA}}=1,25 \mathrm{mg} / \mathrm{mL}\right) \sim 200 \mathrm{~nm}$-ig $(\mathrm{CPLA}=10 \mathrm{mg} / \mathrm{mL})$ szisztematikusan nő.

5. táblázat: Nanoprecipitációval előállított TP-tartalmú PLA részecskék átlagos részecske átmérő értékei, a polidiszperzitási indexek (PI), valamint a $\mathrm{EE}(\%)$ és $\mathrm{DL}(\%)$ értékek az alkalmazott kezdeti koncentrációk esetében

\begin{tabular}{|c|c|c|c|c|c|c|c|}
\hline \multirow[b]{2}{*}{ Minta } & \multicolumn{2}{|c|}{$\begin{array}{c}\text { Acetonos } \\
\text { Fázis }\end{array}$} & \multirow{2}{*}{$\begin{array}{c}\text { Vizes } \\
\text { Fázis } \\
\text { cPLUR } \\
(\mathrm{mg} / \mathrm{mL})\end{array}$} & \multirow[b]{2}{*}{$\begin{array}{c}\mathbf{d}_{\mathrm{DLS}} \pm \mathrm{SD}^{\#} \\
(\mathbf{n m})\end{array}$} & \multirow[b]{2}{*}{$\mathbf{P I} \pm \mathbf{S D}$} & \multirow[b]{2}{*}{$\begin{array}{l}\mathbf{E E} \\
(\%)\end{array}$} & \multirow[b]{2}{*}{$\begin{array}{l}\text { DL } \\
(\%)\end{array}$} \\
\hline & $\begin{array}{c}\mathbf{c}_{\mathbf{P L A}} \\
(\mathrm{mg} / \mathrm{mL})\end{array}$ & $\begin{array}{c}\mathbf{c}_{\mathrm{TP}} \\
(\mathbf{m g} / \mathbf{m L})\end{array}$ & & & & & \\
\hline \multirow{4}{*}{$\begin{array}{c}\text { PLA } \\
\text { koncentráció } \\
\text { függés }\end{array}$} & 1,25 & 2,5 & 0,1 & $120 \pm 33$ & $0,120 \pm 0,04$ & - & - \\
\hline & 2,5 & 2,5 & 0,1 & $156+28$ & $0,039 \pm 0,01$ & - & - \\
\hline & 5,0 & 2,5 & 0,1 & $179 \pm 35$ & $0,082 \pm 0,04$ & - & - \\
\hline & 10,0 & 2,5 & 0,1 & $201 \pm 38$ & $0,095 \pm 0,02$ & 69,11 & 14,7 \\
\hline \multirow{5}{*}{$\begin{array}{c}\text { TP } \\
\text { koncentráció } \\
\text { függés }\end{array}$} & 10,0 & 0 & 0,1 & $188 \pm 37$ & $0,092 \pm 0,05$ & - & - \\
\hline & 10,0 & 0,5 & 0,1 & $189 \pm 34$ & $0,048 \pm 0,02$ & 91,28 & 4,36 \\
\hline & 10,0 & 1,0 & 0,1 & $192 \pm 30$ & $0,062 \pm 0,03$ & 75,61 & 7,02 \\
\hline & 10,0 & 2,5 & 0,1 & $201 \pm 38$ & $0,095 \pm 0,02$ & 69,11 & 14,7 \\
\hline & 10,0 & 5,0 & 0,1 & $252 \pm 53$ & $0,073 \pm 0,03$ & 66,15 & 24,8 \\
\hline \multirow{5}{*}{$\begin{array}{c}\text { PLUR } \\
\text { koncentráció } \\
\text { függés }\end{array}$} & 10,0 & 2,5 & 0 & $179 \pm 40$ & $0,315 \pm 0,04$ & 72,19 & 15,2 \\
\hline & 10,0 & 2,5 & 0,05 & $178 \pm 21$ & $0,304 \pm 0,09$ & 98,34 & 19,7 \\
\hline & 10,0 & 2,5 & 0,1 & $201 \pm 38$ & $0,095 \pm 0,02$ & 69,11 & 14,7 \\
\hline & 10,0 & 2,5 & 0,5 & $206 \pm 36$ & $0,089 \pm 0,06$ & 57,94 & 12,6 \\
\hline & 10,0 & 2,5 & 1,0 & $212 \pm 36$ & $0,066 \pm 0,02$ & 40,75 & 9,24 \\
\hline
\end{tabular}

\# A csúcsmaximum kísérleti hibája $3 \%$ alatti

A 18. ábrán bemutatott TEM képek alapján megállapítható, hogy kis mennyiségü $(1,25 \mathrm{mg} / \mathrm{mL})$ PLA jelenlétében föleg amorf szerkezetű részecskék és kristályos TP aggregátumok kialakulása valószínüsíthető. Mindezek mellett az alacsony polimer koncentráció miatt a hatóanyag kapszulázhatóságának meghatározása nem kivitelezhető. A mag-héj struktúra kialakulása csak nagyobb $(10 \mathrm{mg} / \mathrm{mL})$ polimer koncentrációknál tapasztalható. A TP koncentráció függésénél megfigyelt változások szerint, a TP 
mennyiségének növelésével, a vártak szerint, a részecskék hidrodinamikai átméröje fokozatosan nö. $\mathrm{c}_{\mathrm{TP}}=5 \mathrm{mg} / \mathrm{mL}$ elérésekor egy nagyobb méretnövekedés figyelhető meg. Ezeket a méretváltozásokat a TEM képek is megerősítik. A TP koncentráció változásakor a mag-héj szerkezet kialakulása már $\mathrm{c}_{\mathrm{TP}}=2,5 \mathrm{mg} / \mathrm{mL}$ esetén jól azonosítható $10 \mathrm{mg} / \mathrm{mL}$ PLA polimer koncentráció alkalmazása mellett. TP mennyiségének további emelésével a részecske magjában lévő hatóanyag jelentős része kristályos formát vesz fel. A minták hatóanyag tartalmát összehasonlítva kitünik, hogy a kapszulázási hatékonyság $(\mathrm{EE}(\%)=$ 91,28 \%- tól $\left(\mathrm{c}_{\mathrm{TP}}=0,5 \mathrm{mg} / \mathrm{mL}\right) \mathrm{EE}(\%)=66,15 \%$-ig $\left.\left(\mathrm{c}_{\mathrm{TP}}=5 \mathrm{mg} / \mathrm{mL}\right)\right)$ a részecskék hatóanyag töltöttségének növekedésével párhuzamosan csökken (DL $(\%)=4,36 \%$-tól $\left(\mathrm{c}_{\mathrm{TP}}=0,5 \mathrm{mg} / \mathrm{mL}\right)$ $\mathrm{DL}(\%)=24,85 \%$-ig $\left.\left(\mathrm{c}_{\mathrm{TP}}=5 \mathrm{mg} / \mathrm{mL}\right)\right)$. Ennek legfőbb oka, hogy a kezdeti koncentráció növelésével a TP egyre kisebb része tud hasznosul a hordozóba vitelekor, függetlenül attól, hogy a részecskében lévő mennyisége növekszik. A hatóanyag hordozóként alkalmazható rendszerek maximálisan elfogadható átmérőjére (kb. 200 nm [2]), a mag kristályosodására és a hatóanyag kapszulázhatóságára tekintettel, a PLUR stabilizátor optimális koncentrációjának meghatározásához a további vizsgálatok $\mathrm{c}_{\mathrm{TP}}=2,5 \mathrm{mg} / \mathrm{mL}$ és $\mathrm{C}_{\mathrm{PLA}}=10$ $\mathrm{mg} / \mathrm{mL}$ beállítása mellett történtek.

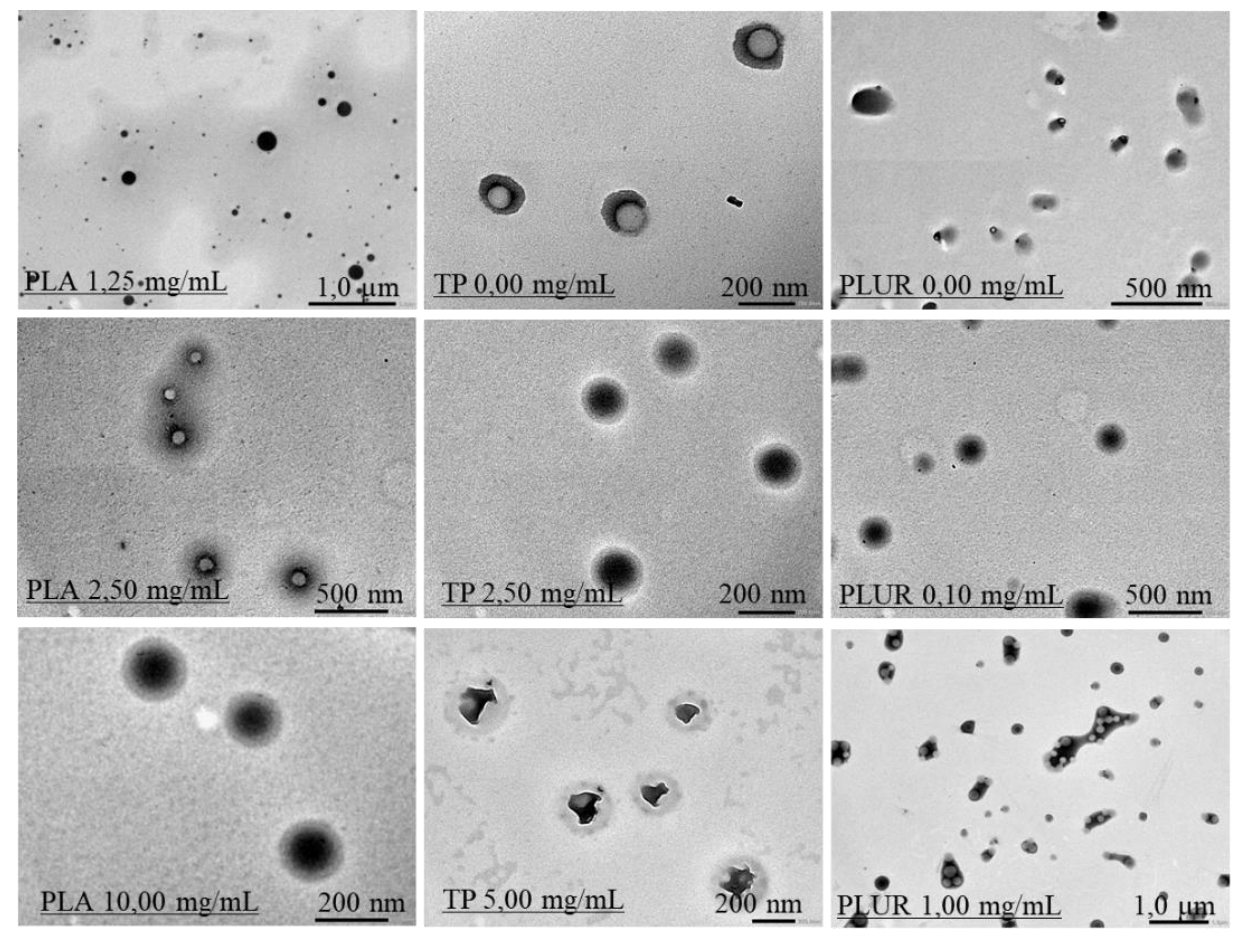

18. ábra: Nanoprecipitációval előállított TP-tartalmú PLA részecskékről készült reprezentatív TEM képek a különböző komponens koncentrációk mellett (PLA függés: $\mathrm{c}_{\mathrm{TP}}=2,5 \mathrm{mg} / \mathrm{mL}, \mathrm{c}_{\mathrm{PLUR}}=0,1 \mathrm{mg} / \mathrm{mL}$, TP függés: $\mathrm{c}_{\mathrm{PLA}}=10 \mathrm{mg} / \mathrm{mL}, \mathrm{c}_{\mathrm{PLUR}}=0,1 \mathrm{mg} / \mathrm{mL}$, PLUR függés: $\mathrm{c}_{\mathrm{PLA}}=10 \mathrm{mg} / \mathrm{mL}, \mathrm{c}_{\mathrm{TP}}=2,5 \mathrm{mg} / \mathrm{mL}$ ) 
A TEM képek alapján megállapítható, hogy a stabilizátor alkalmazásának hiányában a TP kapszulázása nem valósul meg hatékonyan, így feltehetően a hatóanyag a PLA részecskék felületén kötődik meg. A mag-héj szerkezet kialakulásához legalább $c_{P L U R}=0,1$ $\mathrm{mg} / \mathrm{mL}$ szükséges. 1,0 mg/mL koncentrációjú PLUR alkalmazása esetén jelentős mennyiségü stabilizátor marad a részecskék felületén, melynek következtében olykor egy második héj kialakulása is megfigyelhető. A DLS méréseket elemezve, a stabilizátor koncentrációjának növelésével a polidiszperzitási index elörelátható csökkenése $(\mathrm{PI} \approx 0,315$ $\left(\mathrm{c}_{\text {PLUR }}=0 \mathrm{mg} / \mathrm{mL}\right)$-tól $\mathrm{PI} \approx 0,066\left(\mathrm{C}_{\text {PLUR }}=1 \mathrm{mg} / \mathrm{mL}\right)$-ig$)$ ) és a részecskék hidrodinamikai átmérőjének megnövekedése $\left(\sim 179 \mathrm{~nm}\right.$-tól $($ CPLUR $=0 \mathrm{mg} / \mathrm{mL}) \sim 212 \mathrm{~nm}$-ig $\left(\right.$ CPLUR $_{\text {PL }} 1$ $\mathrm{mg} / \mathrm{mL})$ ) tapasztalható. Ez feltételezhetően a felületen egyre nagyobb mennyiségben megkötődő PLUR miatt következik be. Mindezek mellett megfigyelhető, hogy a már stabilizátort tartalmazó mintáknál a kapszulázási hatékonyság és a részecske hatóanyag töltöttsége szisztematikusan csökken (EE(\%): $72 \%$-ról $41 \%$-ra; $\operatorname{DL}(\%)$ : $20 \%$-ról $9 \%$-ra). Ennek pontosabb megismeréséhez a rendszeren turbidimetriás méréseket végeztünk, ahol tanulmányoztuk a PLA és TP oldhatóságának változását a stabilizátor mennyiségének függvényében (19. ábra). A TP oldhatósága, a PLA polimerhez képest, PLUR jelenlétében jelentős mértékben megnövekszik, ezzel csökkentve a kapszulázható hatóanyag mennyiségét. A TEM felvételeket és a turbidimetriás adatokat összegezve az ideális mag-héj szerkezet előállítása $0,1 \mathrm{mg} / \mathrm{mL}$ PLUR jelenlététől elérhető, viszont $>0,1$ $\mathrm{mg} / \mathrm{mL}$ koncentrációnál a kapszulázási hatékonyság csökken, ami a hordozó rendszer felhasználhatósági potenciálját rontja. Ebből fakadóan a hatóanyag hordozóba vitele és a részecske tulajdonságai szerinti ideális koncentráció arányok $\mathrm{c}_{\mathrm{PLUR}}=0,1 \mathrm{mg} / \mathrm{mL}, \mathrm{c}_{\mathrm{TP}}=2,5$ $\mathrm{mg} / \mathrm{mL}, \mathrm{CPLA}=10 \mathrm{mg} / \mathrm{mL}$.
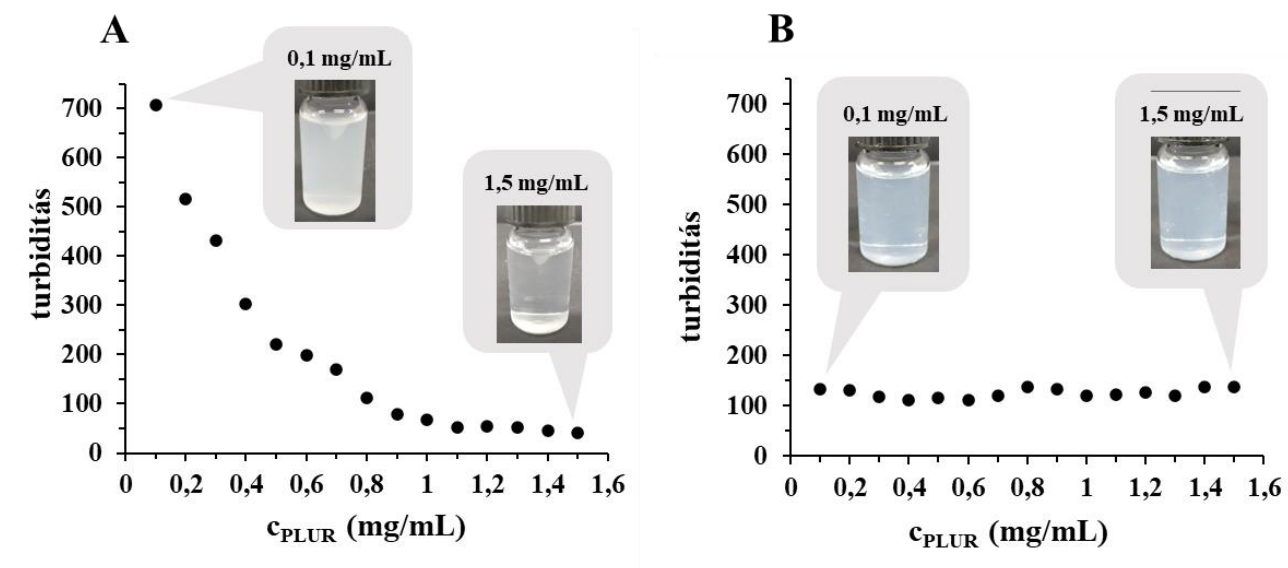

19. ábra: (A) TP- és (B) PLA- tartalmú oldatok turbiditás értékei a PLUR koncentráció függvényében (vizes közeg, $\mathrm{T}=25^{\circ} \mathrm{C}, \mathrm{c}_{\mathrm{TP}}=0,25 \mathrm{mg} / \mathrm{mL}, \mathrm{c}_{\mathrm{PLA}}=0,25 \mathrm{mg} / \mathrm{mL}$ ) 
A PLA alapú rendszerek esetén meghatározott optimális koncentrációk ismeretében tanulmányoztuk továbbá, hogy a kapszulázási hatékonyság növelhető -e a laktid: glikolid arányok változtatásával, illetve a PLGA alapú részecskék szerkezeti tulajdonságai megegyeznek-e a PLA alapú rendszernél kapott tapasztalatokkal. A DLS mérések alapján a polimerekben lévő glikolid mennyiségének növekedésével a részecskeméret 203 nm-től 226 nm-ig folyamatosan nő (20. ábra). Megállapítható, hogy az optimális koncentrációk beállításával PLGA65 és PLGA75 alkalmazásával is megvalósítható a mag-héj szerkezet kialakulása (20. ábra). A rendszereken végzett $\zeta$-potenciál mérések: tisztítás előtt $\zeta=-37,8$ $\pm 1,5 \mathrm{mV}$ (PLGA65), $\zeta=-29,3 \pm 1,2 \mathrm{mV}$ (PLGA75) és $\zeta=-25,3 \pm 1,9 \mathrm{mV}$ (PLA) és tisztitás után $\zeta=-73,5 \pm 1,0 \mathrm{mV}$ (PLGA65), $\zeta=-62,5 \pm 3,0 \mathrm{mV}(\mathrm{KP})$ és $\zeta=-79,2 \pm 2,5 \mathrm{mV}$ (PLA) értékeket mutattak, mely a részecskék nagymértékű stabilitását igazolják. A részecskék EE(\%) és DL(\%) értékeit összehasonlítva a PLA hordozóhoz képest a PLGA75 és PLGA65 vonatkozásában megfigyelhető értékek folyamatosan növekvő tendenciát mutatnak: $\mathrm{EE}(\%)=69,11 \%, \mathrm{DL}(\%)=14,73(\mathrm{PLA}) ; \mathrm{EE}(\%)=75,72 \%$; $\mathrm{DL}(\%)=15,92(\mathrm{PLGA} 75)$ és $\mathrm{EE}(\%)=87,69 \%,(\mathrm{DL}(\%)=17,98(\mathrm{PLGA} 65)$.
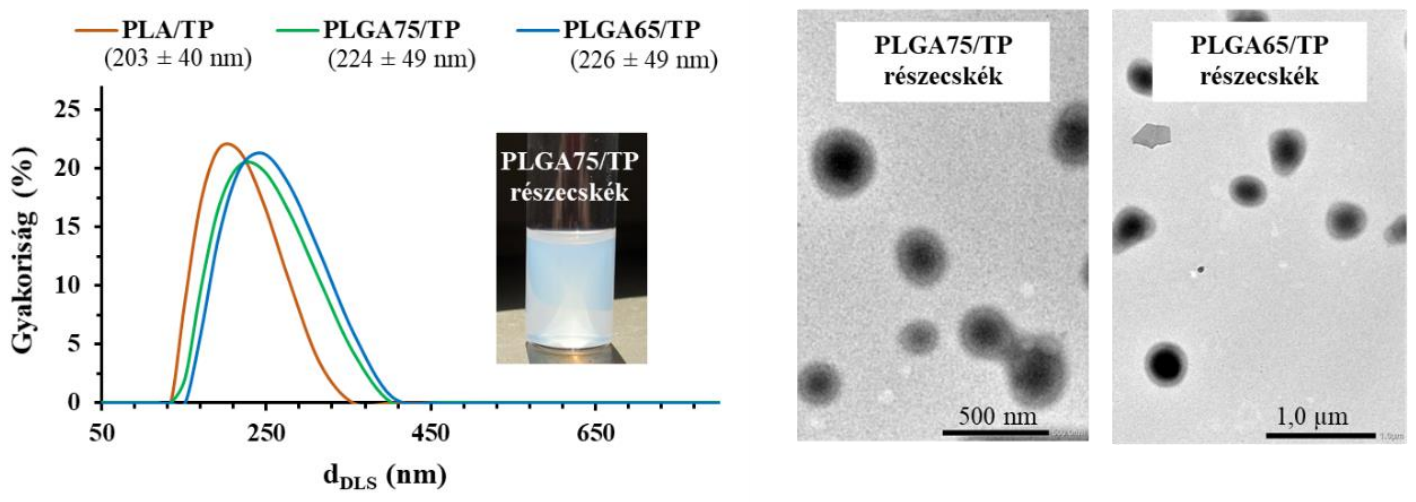

20. ábra: Nanoprecipitációval előállított TP- tartalmú PLA/PLGA részecskék méreteloszlási görbéi és a PLGA75/TP és PLGA65/TP mintákról készült TEM felvételek $\left(\mathrm{c}_{\mathrm{PLGA}}=10 \mathrm{mg} / \mathrm{mL}, \mathrm{c}_{\mathrm{TP}}=2,5 \mathrm{mg} / \mathrm{mL}, \mathrm{c}_{\mathrm{PLUR}}=0,1 \mathrm{mg} / \mathrm{mL}\right)$

A szakirodalomban található TP-tartalmú részecskék hatóanyag töltöttségét, méretét és stabilitását figyelembe véve kijelenthető, hogy az általunk alkalmazott előállítási módszerrel a TP hatékonyabban kapszulázható a PLA/PLGA polimerekbe. Ennek összehasonlítás érdekében a TP-tartalmú és polimer (főként PLGA) alapú részecskék méretét, stabilitását és kapszulázási hatékonyságát bemutató publikációk megfelelő adatait a 6. táblázatban összegeztük. 
6. táblázat: A szakirodalomban jelenleg megtalálható, különböző módszerekkel előállított TP-tartalmú polimer alapú hordozó részecskék átlagos méretei, a ל-potenciál, az EE(\%) és DL(\%) értékek a forrásközlemények megjelölésével

\begin{tabular}{|c|c|c|c|c|c|c|}
\hline Polimer & Stabilizátor & d (nm) & $\zeta(\mathbf{m V})$ & $\mathbf{E E}(\%)$ & DL $(\%)$ & Forrás \\
\hline PLGA50 & $\begin{array}{l}\text { SDS } \\
\text { PVA }\end{array}$ & $\begin{array}{c}50-70^{\mathrm{a}} \\
200-290^{\mathrm{b}}\end{array}$ & $-30--10^{b}$ & $90-95^{\mathrm{b}}$ & - & [116] \\
\hline $\begin{array}{l}\text { PLGA50/ } \\
\text { Chit }\end{array}$ & PVA & $\begin{array}{l}100-110^{\mathrm{c}} \\
110-140^{\mathrm{d}}\end{array}$ & $\begin{array}{r}-35-5^{\mathrm{c}} \\
0-40^{\mathrm{d}}\end{array}$ & $\begin{array}{l}\sim 95^{\mathrm{c}} \\
\sim 80^{\mathrm{d}}\end{array}$ & $\begin{array}{l}\sim 2,5^{\mathrm{c}} \\
\sim 2,0^{\mathrm{d}}\end{array}$ & [121] \\
\hline $\begin{array}{l}\text { PLGA50/ } \\
\text { Chit }\end{array}$ & - & $\begin{array}{c}80-400^{\mathrm{c}} \\
300-3000^{\mathrm{d}}\end{array}$ & $\begin{array}{l}-80-0^{c} \\
-80-60^{d}\end{array}$ & $\begin{array}{c}\sim 45^{\mathrm{c}} \\
50-55^{\mathrm{d}}\end{array}$ & - & [122] \\
\hline $\begin{array}{l}\text { PLGA50/ } \\
\text { Chit }\end{array}$ & PVA & $\begin{array}{l}\sim 130^{\mathrm{c}} \\
\sim 175^{\mathrm{d}}\end{array}$ & $\begin{array}{l}\sim-5^{\mathrm{c}} \\
\sim 10^{\mathrm{d}}\end{array}$ & - & $\begin{array}{l}\sim 4,5^{\mathrm{c}} \\
\sim 4^{\mathrm{d}}\end{array}$ & [123] \\
\hline PCL & PVA & $240-1100$ & $-7--20$ & $25-95$ & $2-3$ & [124] \\
\hline $\begin{array}{l}\text { PNIPAM- } \\
b \text {-PCL- } b- \\
\text { PNIPAM }\end{array}$ & - & $40-300$ & $3-10$ & $40-50$ & $8-10$ & [125] \\
\hline
\end{tabular}

\subsubsection{TP-tartalmú PLGA50 részecskék elöállitása áramlásos kémiai technikával}

Legjobb tudásunk szerint PLGA alapú TP-tartalmú kolloid rendszerek folyamatos áramlási technikával történő előállítására az irodalomban nincs információ. Ezt szemelőt tartva, munkánk során megvizsgáltuk, hogy a korábban részletesen tanulmányozott nanoprecipitációs módszerrel előállított TP-tartalmú mag-héj szerkezetü részecskék folyamatos áramlásos rendszerben is kialakulnak-e, illetve a kezdeti paraméterek (relatív áramlási arány, áramlási sebesség, nyomás) szabályozásával milyen szerkezetbeli és méretbeli változások következnek be. Az alkalmazott mikromixer cellában való aggregáció elkerülése érdekében a kereskedelmi fogalomban kapható, a korábban általunk vizsgált PLGA75/65 kopolimerekhez képest hidrofilebb, PLGA50 kopolimerrel is elvégeztük a részecskék előállítását nanoprecipitációs módszerrel, hogy a mag-héj szerkezet kialakulásához meghatározzuk milyen polimer és TP koncentrációk szükségesek, az 5.2.1. alfejezetben már megállapított optimális koncentráció arányok mellett (CPLUR $=0,1 \mathrm{mg} / \mathrm{mL}$, $\left.\mathrm{c}_{\mathrm{TP}}=2,5 \mathrm{mg} / \mathrm{mL}, \mathrm{c}_{\mathrm{PLA} / \mathrm{PLGA}}=10 \mathrm{mg} / \mathrm{mL}, \mathrm{mPLA}_{\mathrm{PLGA}} / \mathrm{m}_{\mathrm{TP}}=4\right)$. A DLS mérések és TEM felvételek szerint a koncentrációkat $\mathrm{C}_{\mathrm{PLGA50}}=5 \mathrm{mg} / \mathrm{mL}$ és $\mathrm{c}_{\mathrm{TP}}=1,25 \mathrm{mg} / \mathrm{mL}$ értékre csökkentve ( $\left.\mathrm{m}_{\mathrm{PLA} / \mathrm{PLGA}} / \mathrm{m}_{\mathrm{TP}}=4, \mathrm{c}_{\mathrm{PLUR}}=0,1 \mathrm{mg} / \mathrm{mL}\right)$ a korábbi eredmények reprodukálhatóak (21. ábra). 


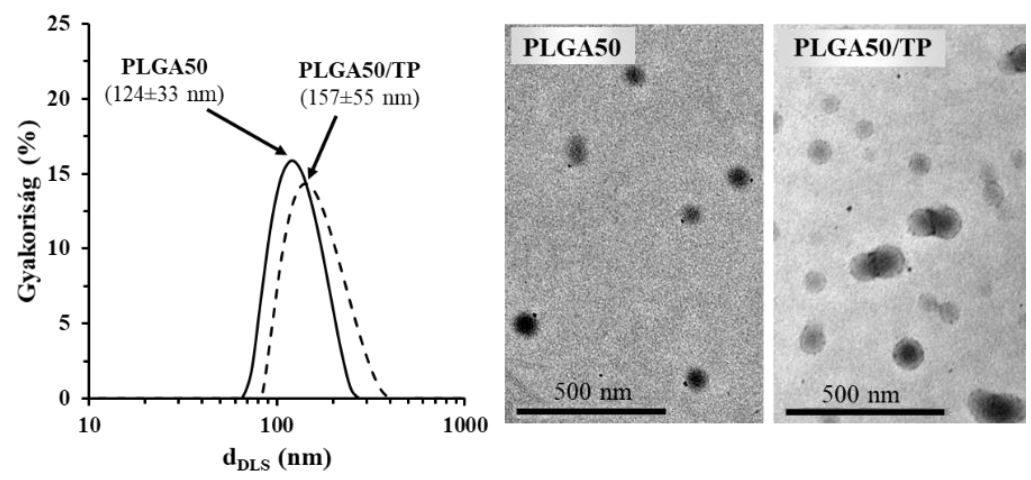

21. ábra: Nanoprecipitációval előállított TP-nélküli és TP-tartalmú PLGA50 részecskék méreteloszlása és TEM felvételei (szerves fázis: $\mathrm{C}_{\mathrm{PLGA} 50}=5 \mathrm{mg} / \mathrm{mL} \mathrm{c}_{\mathrm{TP}}=1,25 \mathrm{mg} / \mathrm{mL}$; vizes fázis: $\left.\mathrm{c}_{\mathrm{PLUR}}=0,1 \mathrm{mg} / \mathrm{mL}\right)$

A PLGA50/TP nanorészecskék hidrodinamikai átmérőjére $\mathrm{d}_{\mathrm{DLS}}=157 \pm 55 \mathrm{~nm}$ értéket határoztunk meg, ami az általunk tapasztaltakkal és az szakirodalomban talált adatokkal jól korrelál (6. táblázat). A fent rögzített koncentrációkat alkalmazva a TP nélküli és TPtartalmú PLGA50 nanorészecskéket $\mu$-mixer cellával rendelkező Syrris Asia Flow rendszerben is előállítottuk. Az egyes mintáknál beállított paramétereket, a részecskék hidrodinamikai átméröit és a polidiszperzitási index értékeket a 7. táblázatban összesítettük.

7. táblázat: PLGA50 alapú TP-nélküli és TP-tartalmú folyamatos áramlásos technikával előállított részecskék DLS módszerrel meghatározott hidrodinamikai átmérője és polidiszperzitási index értékei különböző áramlási paraméterek függvényében

\begin{tabular}{|c|c|c|c|c|c|c|c|}
\hline \multirow{2}{*}{$\begin{array}{c}\text { Acetonos } \\
\text { Fázis } \\
v_{1} \\
(\mu \mathrm{L} / \text { perc }) \\
\end{array}$} & \multirow{2}{*}{$\begin{array}{c}\text { Vizes } \\
\text { Fázis } \\
\mathbf{v}_{\mathbf{2}} \\
(\mu \mathrm{L} / \text { perc })\end{array}$} & \multirow[b]{2}{*}{$\mathbf{v}_{1}: \mathbf{v}_{2}$} & \multirow[b]{2}{*}{$\underset{(\text { bar) }}{\mathbf{p}}$} & \multicolumn{2}{|c|}{$\begin{array}{c}\text { TP-nélküli PLGA50 } \\
\text { részecske }\end{array}$} & \multicolumn{2}{|c|}{$\begin{array}{c}\text { TP-tartalmú PLGA50 } \\
\text { részecske }\end{array}$} \\
\hline & & & & $\begin{array}{c}\mathbf{d}_{\text {DLS }} \pm \mathbf{S D}^{\#} \\
(\mathbf{n m})\end{array}$ & $\mathbf{P I} \pm \mathrm{SD}$ & $\begin{array}{c}\mathbf{d}_{\mathrm{DLS}} \pm \mathrm{SD}^{\#} \\
(\mathbf{n m})\end{array}$ & $\mathrm{PI} \pm \mathrm{SD}$ \\
\hline 25 & 250 & $1: 10$ & - & $144 \pm 37$ & $0,07 \pm 0,03$ & $148 \pm 31$ & $0,07 \pm 0,03$ \\
\hline 25 & 500 & $1: 20$ & - & $147 \pm 35$ & $0,09 \pm 0,04$ & $144 \pm 30$ & $0,05 \pm 0,03$ \\
\hline 25 & 750 & $1: 30$ & - & $153 \pm 31$ & $0,08 \pm 0,06$ & $153 \pm 30$ & $0,04 \pm 0,02$ \\
\hline 25 & 1000 & $1: 40$ & - & $177 \pm 51$ & $0,13 \pm 0,03$ & $153 \pm 38$ & $0,04 \pm 0,03$ \\
\hline 25 & 1250 & $1: 50$ & - & $167 \pm 57$ & $0,17 \pm 0,06$ & $155 \pm 33$ & $0,04 \pm 0,02$ \\
\hline 25 & 250 & $1: 10$ & 2 & $149 \pm 41$ & $0,13 \pm 0,04$ & $158 \pm 36$ & $0,10 \pm 0,04$ \\
\hline 25 & 250 & $1: 10$ & 4 & $146 \pm 38$ & $0,07 \pm 0,02$ & $156 \pm 39$ & $0,09 \pm 0,02$ \\
\hline 25 & 250 & $1: 10$ & 6 & $142 \pm 32$ & $0,04 \pm 0,03$ & $156 \pm 41$ & $0,12 \pm 0,05$ \\
\hline 25 & 250 & $1: 10$ & 8 & $142 \pm 36$ & $0,10 \pm 0,03$ & $153 \pm 40$ & $0,09 \pm 0,02$ \\
\hline 25 & 250 & $1: 10$ & 10 & $142 \pm 36$ & $0,07 \pm 0,04$ & $153 \pm 40$ & $0,09 \pm 0,02$ \\
\hline 25 & 250 & $1: 10$ & - & $144 \pm 37$ & $0,07 \pm 0,03$ & $148 \pm 31$ & $0,07 \pm 0,03$ \\
\hline 50 & 500 & $1: 10$ & - & $137 \pm 36$ & $0,10 \pm 0,06$ & $141 \pm 32$ & $0,11 \pm 0,03$ \\
\hline 75 & 750 & $1: 10$ & - & $142 \pm 35$ & $0,09 \pm 0,04$ & $134 \pm 27$ & $0,09 \pm 0,04$ \\
\hline 100 & 1000 & $1: 10$ & - & $132 \pm 33$ & $0,10 \pm 0,03$ & $167 \pm 48$ & $0,15 \pm 0,02$ \\
\hline 150 & 1500 & $1: 10$ & - & $159 \pm 44$ & $0,10 \pm 0,06$ & $157 \pm 43$ & $0,10 \pm 0,03$ \\
\hline
\end{tabular}

\# A csúcsmaximum kísérleti hibája $3 \%$ alatti 
Megállapítottuk, hogy a relatív áramlási arány $\left(\mathrm{v}_{1}: \mathrm{v}_{2}\right)$ változtatása 1:10 -ről 1:50 értékre a hatóanyag nélküli nanorészecskéknél a méret növekedését eredményezi $\mathrm{d}_{\mathrm{DLS}} \approx 144$ nm-ről $\mathrm{d}_{\mathrm{DLS}} \approx 167 \mathrm{~nm}$-re, míg a polidiszperzitási index $\mathrm{PI} \approx 0,07$-ről $\mathrm{PI} \approx 0,17$-re nő, de a PLGA50/TP mintáknál csak kismértékü változás történik $\left(\mathrm{d}_{\mathrm{DLS}}=144-155 \mathrm{~nm}, \mathrm{PI}=0,04\right.$ 0,07). A $\mu$-mixer cellában beállítható nyomások növelésével sem a PLGA50 részecskéknél, sem a PLGA50/TP rendszer vonatkozásában nem látható változás. Ez jól mutatja, hogy a hatóanyag tartalmú nanorészecskékre a nyomás és a relatív áramlási arányok változtatása nincs jelentősebb hatással. Az áramlási sebesség változtatásánál a relatív áramlási arányát állandó 1:10 értéken tartottuk. A 7. táblázatból jól látható, hogy egy jól meghatározott áramlási sebesség értékig jelentősebb változás nem figyelhető meg (PLGA50: $\mathrm{d}_{\mathrm{DLS}}=132$ 144 nm, PLGA50/TP: $d_{\text {DLS }}=134-148$ nm). Egy kritikus értéket elérve a hidrodinamikai átmérő hirtelen növekedést mutat. Hatóanyag nélküli PLGA50 részecskéknél ez $150 \mu \mathrm{L} /$ perc : $1500 \mu \mathrm{L} /$ perc $\left(\mathrm{d}_{\mathrm{DLS}} \approx 159 \mathrm{~nm}\right)$, míg TP-tartalmú PLGA50 részecskéknél $100 \mu \mathrm{L} /$ perc : $1000 \mu \mathrm{L} /$ perc $\left(\mathrm{d}_{\mathrm{DLS}} \approx 167 \mathrm{~nm}\right)$ acetonos fázis : vizes fázis áramlási sebességeknél valósul meg. A részecskeméret szempontjából optimális áramlási sebességeket $75 \mu \mathrm{L} /$ perc (acetonos fázis) és $750 \mu \mathrm{L} /$ perc (vizes fázis) esetén állapítottuk meg (PLGA50: $\mathrm{d}_{\mathrm{DLS}} \approx 134 \mathrm{~nm}$ ). Ezt a rögzített TEM felvételek is megerősítik, ahol 75:750 $\mu \mathrm{L} /$ perc esetén egy jól definiált maghéj szerkezet kialakulását láthatjuk (22. ábra, $\mathrm{d}_{\mathrm{TEM}}=132 \pm 22 \mathrm{~nm}$ ). Alacsonyabb sebességeknél a TP nem kerül a polimer hordozó magjába, míg túl magas értékeknél a részecskék már roncsolódnak, ami feltételezhetően a hidrodinamikai átméröben történő növekedést is okozza (7. táblázat). A minták polidiszperzitását nézve a folyamatos áramlási rendszerben 75:750 $\mu \mathrm{L} /$ perc alkalmazása mellett, a nanoprecipitációs módszerhez képest, lényegesen monodiszperzebb rendszert kapunk.
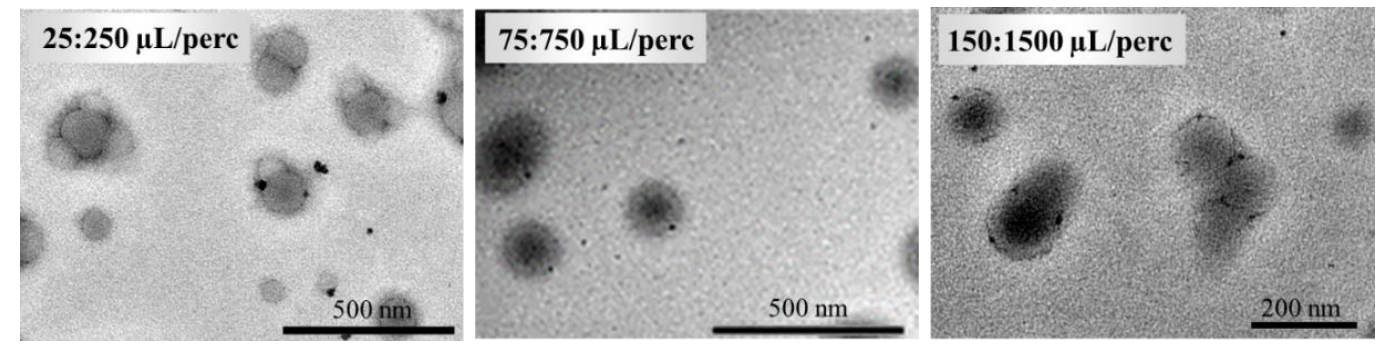

22. ábra: Különböző $\mathrm{v}_{1}: \mathrm{v}_{2}$ áramlási sebességeken elkészített TP-tartalmú PLGA50 részecskék reprezentatív TEM képei (szerves fázis: $\mathrm{CPLGA}_{0}=5 \mathrm{mg} / \mathrm{mL}, \mathrm{c}_{\mathrm{TP}}=1,25 \mathrm{mg} / \mathrm{mL}$; vizes fázis: $\mathrm{C}_{\mathrm{PLUR}}=0,1 \mathrm{mg} / \mathrm{mL}$ ).

A részecskék méretének és méreteloszlásának jellemzésén túl a DL(\%) és az EE(\%) értékeket is meghatároztuk mindkét módszernél. A nanoprecipitációnál $\mathrm{EE}(\%)=67,1 \%$ 
(DL $(\%)=14,4 \%)$, míg az áramlásos technikánál (szerves: vizes fázis áramlási sebesség: 75:750 $\mu \mathrm{L} /$ perc $) \operatorname{EE}(\%)=71,5 \%(\mathrm{DL}(\%)=15,2 \%)$ értéket kaptunk, így kijelenthető, hogy a két módszer hasonló kapszulázási hatékonysággal rendelkezik. A 5.2.1. alfejezetben már említett szakirodalomban található PLGA50/TP részecskékhez képest is egy monodiszperzebb és nagy kapszulázási hatékonysággal rendelkező rendszert állítottunk elő [116,121-123], amely előnyét a nagy mintamennyiség előállításának lehetősége még inkább növeli.

\subsubsection{TP-tartalmú PLA/PLGA részecskék szerkezeti karakterizálása}

A részecskéken belül kialakuló kölcsönhatások megismerése érdekében a tisztított és liofilizált mintákon FT-IR spektroszkópiás méréseket végeztünk. A PLA alapú részecskéknél a $-\mathrm{CH}_{2}$ és $-\mathrm{CH}_{3}$ csoportokhoz köthető aszimmetrikus és szimmetrikus rezgési sávok (2994 cm-1 $2944 \mathrm{~cm}^{-1}$ és $\left.2868 \mathrm{~cm}^{-1}\right)$ intenzitása TP jelenlétében nagyobb (23. ábra) $[81,82,126]$.

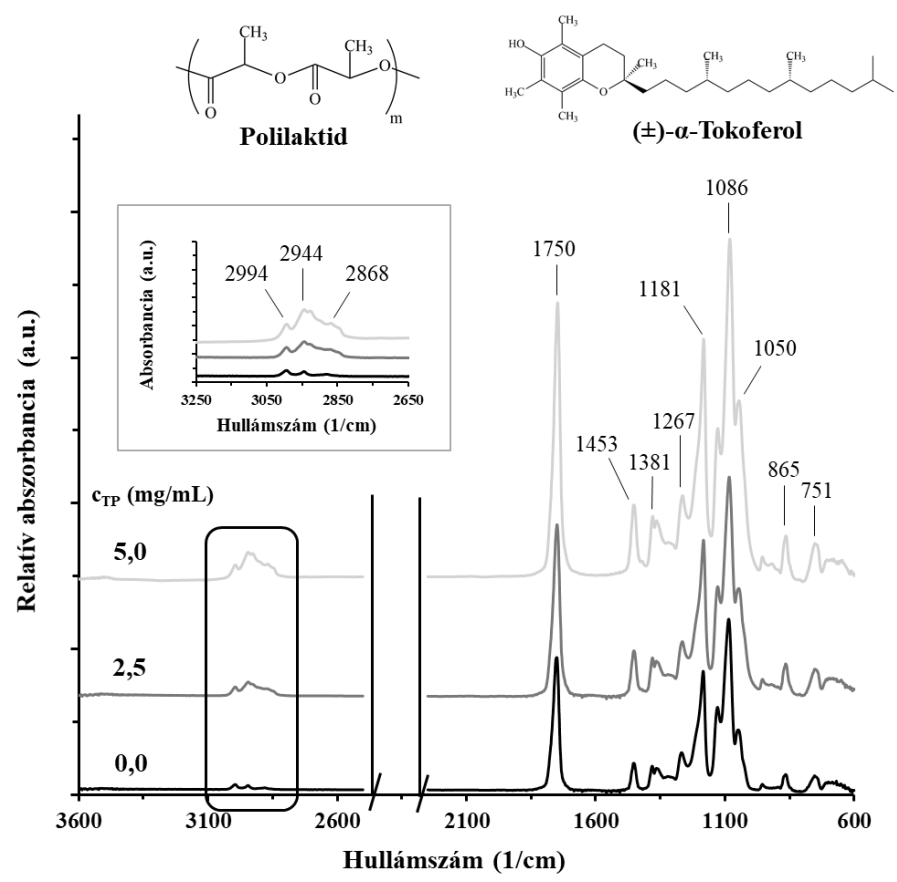

23. ábra: A PLA és TP-tartalmú PLA részecskék liofilizált pormintáinak FT-IR spektrumai (szerves fázis: $\mathrm{c}_{\mathrm{PLA}}=10 \mathrm{mg} / \mathrm{mL}$, vizes fázis: $\mathrm{c}_{\mathrm{PLUR}}=0,1 \mathrm{mg} / \mathrm{mL}$ )

A karbonilcsoport $1750 \mathrm{~cm}^{-1}$ hullámszámnál azonosítható, függetlenül a vitamin koncentrációjától. Mivel a TP szerkezetén belül nincs $\mathrm{C}=\mathrm{O}$ csoport, ezért ez kifejezetten a polimerhez tartozó rezgési sáv. A $v>1500 \mathrm{~cm}^{-1}$ tartományon a - $\mathrm{CH}_{2}$ és $-\mathrm{CH}_{3}$ deformációs és hajlító rezgései $1453 \mathrm{~cm}^{-1}, 1381 \mathrm{~cm}^{-1}$ és $1267 \mathrm{~cm}^{-1}$-nél, míg a C-O-C nyújtó rezgési sávjai 
$1181 \mathrm{~cm}^{-1}$ és $1086 \mathrm{~cm}^{-1}$-nél találhatóak. A TP -ban lévő Ar-O-C csoportnak köszönhetően a C-O-C szimmetrikus nyújtási rezgés sáv relatív abszorbancia értéke $1050 \mathrm{~cm}^{-1}$-nél a koncentráció megnövekedésével nő. A különböző mennyiségü TP-tartalmazó PLA minták spektrumait összegezve a TP -ra érzékeny rezgési sávok főként 3050-2800 $\mathrm{cm}^{-1}$ és az ujjlenyomat tartományon belül $1150-1000 \mathrm{~cm}^{-1}$ találhatóak. Új sávok megjelenése nem figyelhető meg, mely alapján a polimer-hatóanyag között erősebb kölcsönhatás kialakulása nem valószínüsíthető. Az FT-IR spektrumokat PLGA50, PLGA65 és PLGA75 TP-tartalmú rendszerekre és tiszta polimerekre is hasonló következtetés vonható le, melyek közül reprezentatív módon a PLGA65 FT-IR spektrumait mutatjuk be a M48. ábrán. Feltételezhetjük tehát, hogy a mag-héj szerkezet kialakulása nem erős irreverzibilis kölcsönhatások kialakulásának köszönhető, ami meghatározó lehet a TP kioldódás folyamatára a hordozó mátrixból.

A TP és PLUR közötti kölcsönhatások megismerése érdekében turbidimetriás méréseket végeztünk nagy tisztaságú Milli-Q vizes közegben $25^{\circ} \mathrm{C}$-on (24.A. ábra), illetve PBS oldatban $25^{\circ} \mathrm{C}$ (24.B. ábra) és $37^{\circ} \mathrm{C}$ (24.C. ábra) hőmérsékleteken, mely eredmények nagyban hozzájárulnak a részecskék előállításhoz alkalmazott komponens koncentrációk optimalizálásához, és a hatóanyag felszabadulás értelmezéséhez is. A rendszer turbiditás változását 1 h, 3 h és 6 h után határoztuk meg.
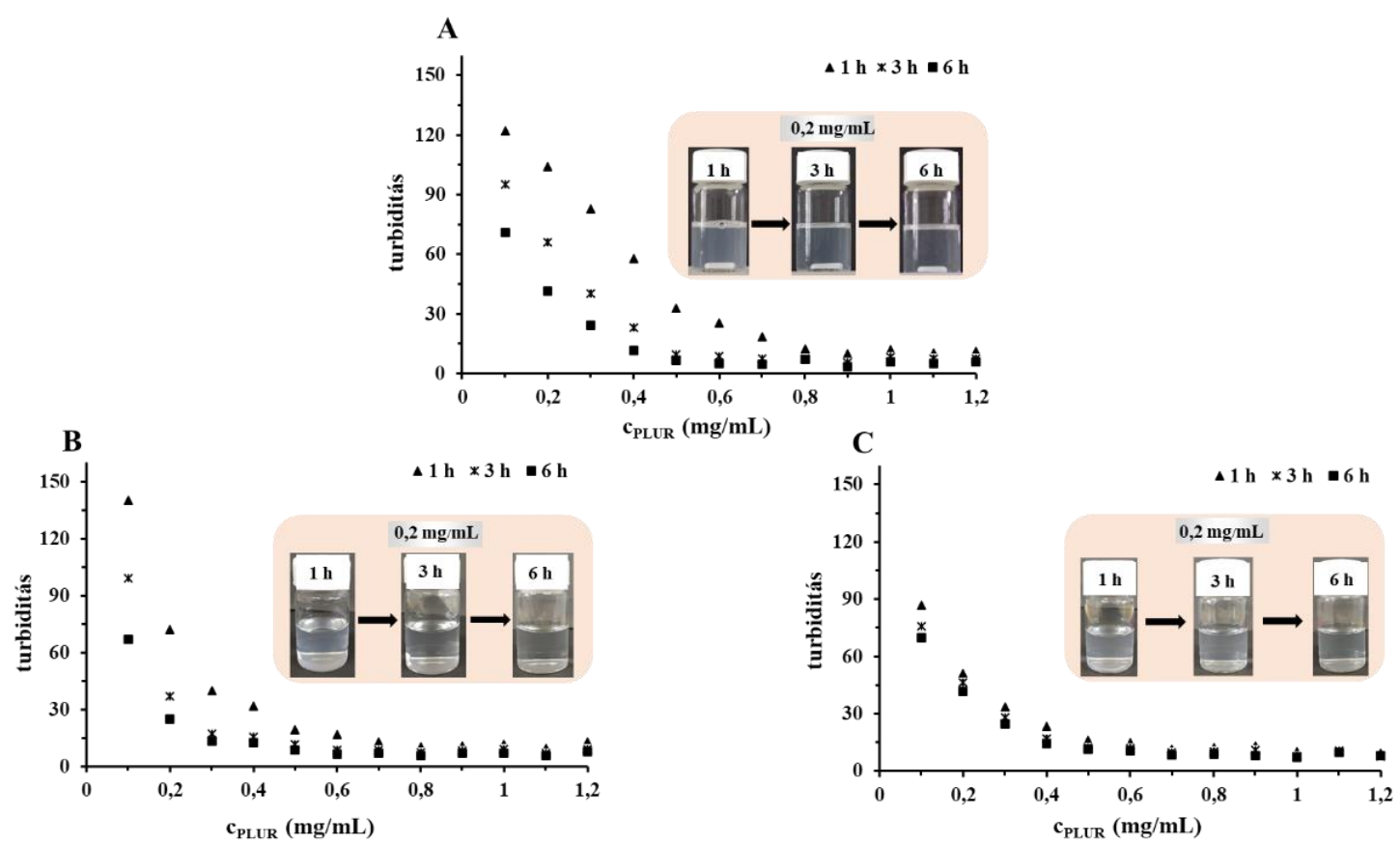

24. ábra: TP turbiditás változása PLUR-tartalmú vizes $\left(25^{\circ} \mathrm{C}(\mathbf{A})\right)$ és $\mathrm{PBS}(\mathrm{pH}=7,4 ; 0,9$ $\mathrm{w} / \mathrm{w} \% \mathrm{NaCl} ; 25^{\circ} \mathrm{C}(\mathbf{B})$ és $\left.37{ }^{\circ} \mathrm{C}(\mathbf{C})\right)$ oldatokban $\left(\mathrm{c}_{\mathrm{TP}}=0,05 \mathrm{mg} / \mathrm{mL}\right)$ 
A Milli-Q vizes közegben elvégzett kísérleteknél látható, hogy a turbiditás $0,9 \mathrm{mg} / \mathrm{mL}$ PLUR koncentráció értékig szisztematikusan csökken $1 \mathrm{~h}$ kevertetés után és a TP oldhatósága az idő függvényében nő, melyet alátámaszt a turbiditás értékek fokozatos csökkenése ugyanazon $25^{\circ} \mathrm{C}$-os mintasorozat esetén. 6 óra eltelte után a minimum érték 0,9 $\mathrm{mg} / \mathrm{mL}-$ ről 0,5 mg/mL -re tolódik el, így kijelenthető, hogy hosszabb keverési idők mellett kisebb PLUR koncentráció alkalmazása is elegendő. A PBS közegben készített mintáknál 1 óra után egy meredekebb turbiditás esést tapasztaltunk, feltételezhetően a puffer oldatban lévő sók jelenlétével indukált PLUR $c m c$ értékének eltolódása miatt. 6 óra után a vizes közeghez képest kisebb csökkenés látható. A hőmérséklet $37^{\circ} \mathrm{C}$-ra történő növelésével a kezdeti minimum turbiditás $\mathrm{c}_{\text {PLUR }}=0,7 \mathrm{mg} / \mathrm{mL}$-röl $\left(25^{\circ} \mathrm{C}\right) \mathrm{c}_{\text {PLUR }}=0,6 \mathrm{mg} / \mathrm{mL}$-re csökken $\left(37^{\circ} \mathrm{C}\right)$. Ebben az esetben a TP oldhatósága 6 óra után sem változik a kezdeti értékekhez képest, így PLUR jelenlétében is kivitelezhető a TP in vitro kioldódásának tanulmányozása $37^{\circ} \mathrm{C}$ hömérsékleten.

A stabilizátorok $c m c$ feletti koncentrációjánál a hatóanyagok nagyrésze a kialakuló individuális micellákba kapszulázódik [127], míg alacsonyabb koncentrációknál a stabilizátornak főként az oldhatóság növelésére gyakorolt hatása figyelhető meg. Annak érdekében, hogy a TP PLUR-tartalmú közegben történő oldhatóságáról részletesebb információt szerezzünk, meghatároztuk a PLUR $c m c$ értékét Milli-Q vizes és PBS közegben felületi feszültség mérésekkel (25. ábra).

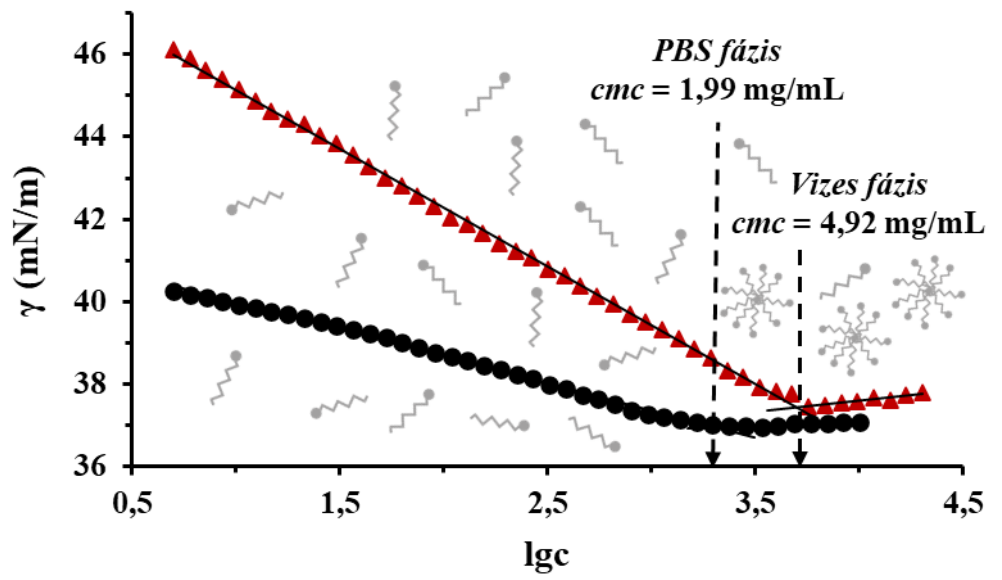

25. ábra: A PLUR $c m c$ értékének meghatározása Milli-Q vizes ( $\boldsymbol{\Delta})$ és PBS (•) közegben $\left(\mathrm{t}=25^{\circ} \mathrm{C}\right)$

Az irodalomban található PLUR felületaktív anyaggal kapcsolatos $\mathrm{cmc}$ értékek nagyon széles skálán változnak ( $25^{\circ} \mathrm{C}$-on vizes közegben: $\left.1-7 \mathrm{mg} / \mathrm{mL}\right)$ [86,128-130]. A cmc 
reproduktív módon történő meghatározása után $25{ }^{\circ} \mathrm{C}$ hömérsékleten Milli-Q vizes közegben $c m c=4,92 \mathrm{mg} / \mathrm{mL}$ kaptunk, ami PBS oldatban $c m c=1,99 \mathrm{mg} / \mathrm{mL}$ értékre csökken. Megállapíthatjuk tehát, hogy a turbidimetriás mérésekhez alkalmazott PLUR koncentráció tartomány $(0-1 \mathrm{mg} / \mathrm{mL})$ messze a $c m c$ érték alatt található, ezáltal a PLUR jelenléte ténylegesen a TP oldhatóságát növeli.

\subsubsection{TP in vitro kioldódási vizsgálata PLA/PLGA részecskékböl}

A TP-tartalmú PLA/PLGA rendszerek karakterizálását követően megkíséreltük a hatóanyag kioldódás folyamatát és annak mechanizmusát tanulmányozni. A szakirodalomban az in vitro kioldódási kísérleteket az általunk is alkalmazott hordozó rendszerekre főként több napos intervallumon végezték el, ezért a kezdeti szakaszon lejátszódó folyamatokról részletesebb információt nem szolgáltattak. Mindezek túl a hatóanyag felszabadulás kinetikai sajátságait sem tanulmányozták részletesen [116,121123]. Ezek ismeretében, vizsgálataink során meghatároztuk a kioldódási folyamatokat mind a nanoprecipitációs, mind a folyamatos áramlásos kémiai technikával előállított PLA/PLGA alapú mintáknál (26. ábra és M49. ábra). Az egyes rendszerek kinetikai tulajdonságait nemlineáris regresszióval illesztett Korsmeyer-Peppas, Weibull és elsőrendű kinetikai modellekkel (12.-14. egyenlet) definiáltuk.

A

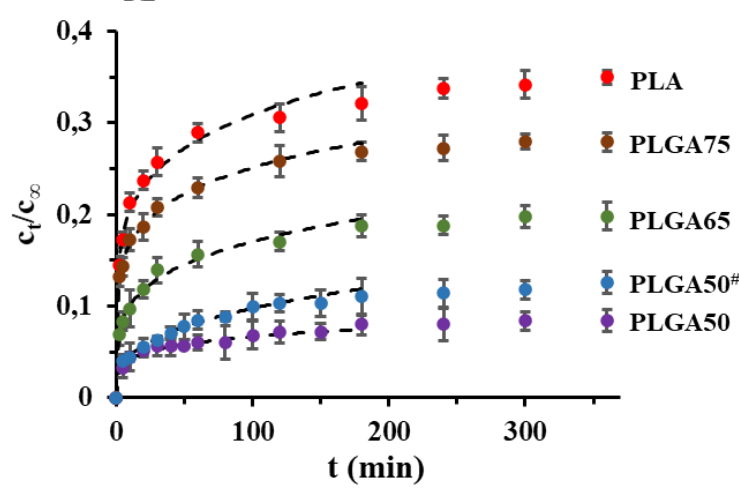

B

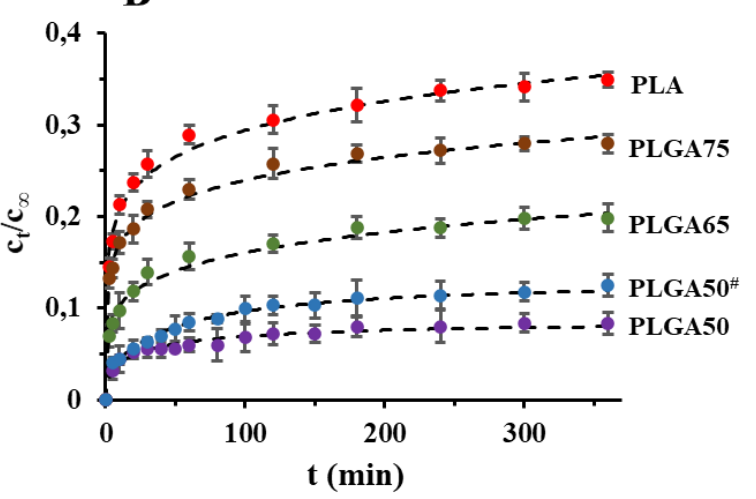

26. ábra: A különböző TP-tartalmú PLA/PLGA részecskékből a hatóanyag PBS közegben regisztrált kioldódási görbéi (• jelölt), illetve a mérési pontokra (A) Korsmeyer-Peppas és (B) Weibull kinetikai modellekkel történő illesztések (szaggatott vonallal jelölt) $\left(\mathrm{T}=37^{\circ} \mathrm{C}\right.$, $\left.\mathrm{pH}=7,4 ; 0,9 \% \mathrm{NaCl} ; \mathrm{c}_{\mathrm{PLUR}}=1 \mathrm{mg} / \mathrm{mL}\right)(\#$ : folyamatos áramlásos technikával elóállított részecskék)

A felvett kioldódási görbéken jól látható, hogy a hordozó hidrofilitásának növekedésével a kioldódása folyamatosan lassul. 7 óra után a felszabadult TP mennyisége a következőek 
szerint változik: 35,0 \% (PLA), 28,3 \% (PLGA75), 19,8\% (PLGA65), 8,0 \% (PLGA50, nanoprecipitáció), 12,0 \% (PLGA50, áramlásos technika). I. G. Zigoneanu és munkatársai korábban megállapították, hogy a TP-tartalmú PLGA50 alapú hordozó részecskék esetén a kisebb hatóanyag töltöttségű részecskék gyorsabb leadóképességgel bírnak [116]. Ez megfelel az általunk vizsgált rendszerre is, ahol a legnagyobb hatóanyag kioldódás a leghidrofóbabb és a viszonylag legkisebb hatóanyag-tartalmú PLA hordozónál tapasztalható $(\mathrm{DL}(\%)=14,7 \% \quad(\mathrm{PLA}) ; \mathrm{DL}(\%)=15,9 \% \quad(\mathrm{PLGA75}) ; \mathrm{DL}(\%)=18,0$ (PLGA65); DL $(\%)=14,4 \%$ (nanoprecipitáció, PLGA50; DL $(\%)=15,2 \%$ (áramlásos technika, PLGA50)). Fontos kiemelni, hogy a PLGA50 esetében kis kapszulázási hatékonyságához képest kisebb kioldódás társul. Ezt a hidrofilitási tulajdonság változásával magyarázhatjuk. A hidrofóbabb karakterü részecskéknél nagyobb mennyiségü TP tud megkötődni a felület közelében, ahonnan a hatóanyag kioldódása lényegesen gyorsabban végbemegy. Ennek köszönhető, hogy a görbék kezdeti 0-20 perces tartományán hirtelen lejátszódó TP felszabadulás a polimerben lévő glikolid arányának csökkenésével egyre növekszik. Ez egyértelmủen alátámasztja, miszerint a rövidtávú kioldódási folyamatokat a részecskék hatóanyagtartalmán kívül az alkalmazott polimerek hidrofilitása is jelentősen befolyásolja.

A kioldódási görbékre illesztett kinetikai modellek determinációs együtthatói szerint a legjobb illeszkedést a Korsmeyer-Peppas (26.A. ábra), míg a második legjobb illeszkedést a Weibull (26.B. ábra) egyenlet adja (8. táblázat).

8. táblázat: A TP -tartalmú PLA/PLGA alapú hordozó rendszerek kioldódási görbéire illesztett kinetikai modellek (12-14. egyenlet) megfelelő paraméterei

\begin{tabular}{|c|c|c|c|c|c|c|c|c|}
\hline \multirow{2}{*}{$\begin{array}{l}\text { Modell } \\
\text { Minta }\end{array}$} & \multicolumn{2}{|c|}{ Elsőrendü } & \multicolumn{3}{|c|}{ Korsmeyer-Peppas } & \multicolumn{3}{|c|}{ Weibull } \\
\hline & $\begin{array}{c}\mathrm{k} \\
\left(\mathrm{min}^{-1}\right)\end{array}$ & $\mathrm{R}^{2}$ & $\begin{array}{c}\mathrm{k}_{\mathrm{m}} \\
\left(\mathrm{min}^{-\mathrm{n}}\right)\end{array}$ & $\mathrm{n}$ & $\mathrm{R}^{2}$ & $\mathrm{a}$ & $\mathrm{b}$ & $\mathrm{R}^{2}$ \\
\hline PLA & 0,0094 & 0,9792 & 0,1339 & 0,182 & 0,9898 & 6,52 & 0,178 & 0,9896 \\
\hline PLGA75 & 0,0113 & 0,9532 & 0,1120 & 0,175 & 0,9982 & 7,85 & 0,166 & 0,9819 \\
\hline PLGA65 & 0,0130 & 0,9514 & 0,0592 & 0,223 & 0,9904 & 15,45 & 0,220 & 0,9898 \\
\hline PLGA50 & 0,0115 & 0,9189 & 0,3200 & 0,197 & 0,9793 & 4,16 & 0,430 & 0,9728 \\
\hline PLGA50\# & 0,0088 & 0,9497 & 0,1680 & 0,333 & 0,9934 & 8,37 & 0,545 & 0,9882 \\
\hline
\end{tabular}

\#: folyamatos áramlásos technikával előállított részecskék

A Korsmeyer-Peppas modellből szerezhető kinetikai paraméterek $\left(\mathrm{k}_{\mathrm{m}}, \mathrm{n}\right)$ jelentős információ tartalommal rendelkeznek. A hatóanyag kioldódását jellemző diffúziós-oldódási 
index $n=0,175-0,333$ közötti értékeket vesz fel, amely kvázi Fick - diffúzió kontrollált hatóanyag leadásra utal. Ekkor a polimer hordozóban végbemenő eróziós folyamatok a TP felszabadulására jelentős hatással nem bírnak. A hatóanyag felszabadulását nézve a hordozó hidrofilitásának növelése a hatóanyag visszatartását fokozza, azonban a kioldódás diffúzió kontrollált jellegére nem lesz hatással. A diffúziós-oldódási index minden esetben $n=0,42$ nél kisebb. Ez a rendszer polidiszperzitása miatt lehetséges [131]. A mért és a számított eredmények egyértelmüen igazolják, hogy a hatóanyag felszabadulás főleg a PLA/PLGA részecskék felülete közeléből történt. Ennek köszönhetően meghatározható a mag-ban lévő TP mennyiségének értéke 7 óra letelte után: DL(\%)=9,6 \% (PLA); DL(\%)=11,4\% $($ PLGA75); DL $(\%)=14,4 \%($ PLGA65); DL $(\%)=13,2 \%$ (PLGA50, nanoprecipitáció); $\mathrm{DL}(\%)=13,4 \%$ (PLGA50, áramlásos technika). Az értékek jól mutatják, hogy a hidrofilitás növelésével a magban lévő hatóanyag mennyisége fokozatosan növelhető.

\subsection{Keresztkötött és CTAB -dal részlegesen hidrofóbizált HyA nanorészecskék előállítása, szerkezetvizsgálata és felhasználásuk KP kapszulázására}

A korábbi fejezetekben tárgyalt PLA/PLGA polimerekkel kapcsolatos vizsgálatoknál a polimerek és hatóanyagok hidrofilitásának, illetve az előállítási protokollokhoz alkalmazott kiindulási paraméterek változásának hatásával szabályozható tulajdonságokat (pl. méret, morfológia, kapszulázási hatékonyság) tanulmányoztuk. Ezen vizsgálatokat folytatva a kutatási munkánkat a hidrofil tulajdonságú hialuronsav poliszacharidra is kiterjesztettük. A doktori munkám második felében a HyA különbözö technikákkal megvalósítható hidrofóbizálását végeztük el, annak érdekében, hogy hordozóként is alkalmazható nanorészecskéket állíthassunk elő.

\subsubsection{Keresztkötött HyA nanorészecskék elöállitása és karakterizálása}

A 2.2.2. alfejezetben korábban részletezettek alapján a HyA térhálósításával (keresztkötések kialakítása révén) hatóanyag hordozó rendszerek állíthatóak elő [106], amelyhez gyakran alkalmaznak különböző diaminokat (karbodiimides technika) [60,104,105]. Ezt alapul véve, reproduktív módon szintetizáltunk diaminos kapcsolással különböző mértékben keresztkötött HyA makromolekulákat (cl-M-HyA) (27. ábra). Munkánk során, a korábbi publikációkban ismertetett rendszerekkel szemben [60,104,105] egy viszonylag kisebb molekulatömegü HyA -t használtunk fel (M-HyA: $\mathrm{M}_{\mathrm{w}}=200-500$ kDa, Richter Gedeon Nyrt.) a kisebb részecskeméret elérése érdekében. A keresztkötést 50, 75 és $100 \%$ mértékü térhálósítás beállítása mellett kiviteleztük. A tisztított rendszerek esetén a 
kötések igazolása érdekében FT-IR spektroszkópiás méréseket végeztünk (27. ábra). A tiszta M-HyA esetén az -OH és -NH csoportok rezgési sávjai $3319 \mathrm{~cm}^{-1}$ és $2953 \mathrm{~cm}^{-1}$ hullámszámnál találhatóak. Alacsonyabb hullámszám értékeknél a karboxilátcsoport szimmetrikus C-O nyújtó rezgése $1408 \mathrm{~cm}^{-1}$-nél jelenik meg [132]. A cl-M-HyA /75\% spektrumán megfigyelhető, hogy a M-HyA $1604 \mathrm{~cm}^{-1}$-nél látható karboxilátcsoporthoz tartozó aszimmetrikus C-O nyújtórezgési sávja jelentősen eltolódik $1642 \mathrm{~cm}^{-1}$ hullámszámra az -amid I csúcs felé, ami a keresztkötés kialakulásának sikereségét mutatja [133-136]. Mindezek mellett a keresztkötött M-HyA esetén $1514 \mathrm{~cm}^{-1}$-nél az -amid II sávhoz tartozó kisebb rezgési elnyelés is megjelenik.
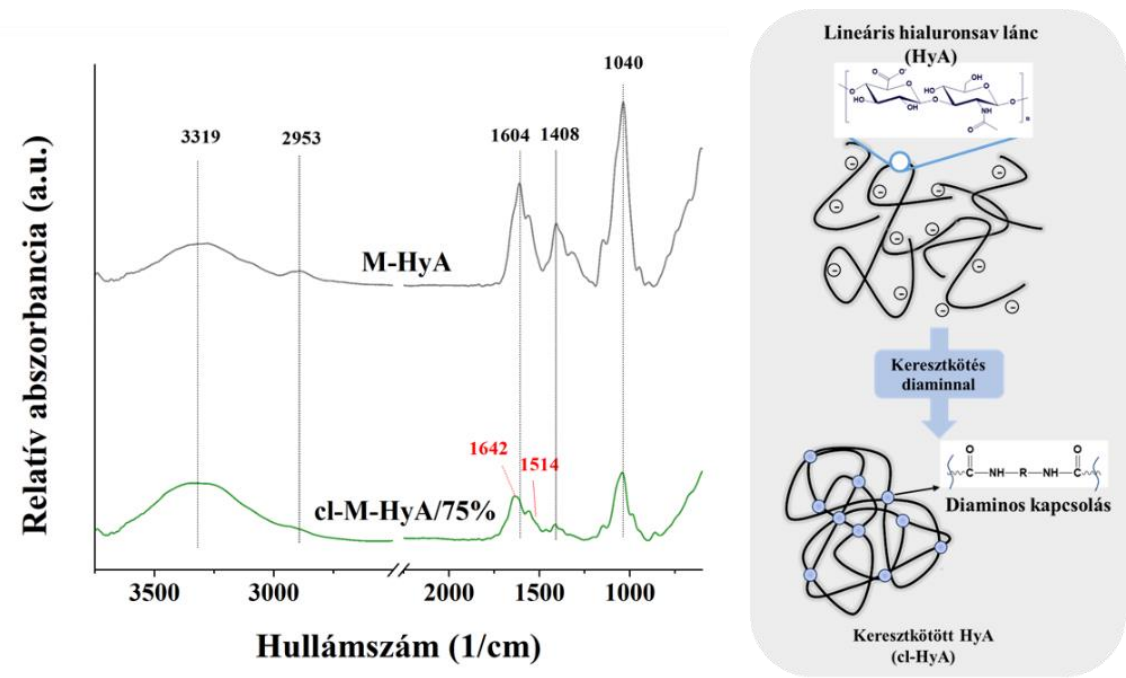

27. ábra: A liofilizált és 75\% -ban keresztkötött M-HyA (cl-M-HyA/75\%) és a kiindulási M-HyA FT-IR spektrumainak részlete (bal oldal) illetve a szintézis sematikus ábrája (jobb oldal)

A mintákat ezt követően termoanalitikai mérésekkel is karakterizáltuk (28. ábra). Referenciaként az EDEA és a tiszta M-HyA termikus sajátságait is megvizsgáltuk. A MHyA hidrofil tulajdonságának köszönhetően a kiindulási és a keresztkötött cl-HyA is nagy mennyiségü vizet tartalmaz, mely a M-HyA esetén ez a bemért tömeg $13 \%$-át, míg cl-MHyA/75\% esetén a $19 \%$-át teszi ki. A fizikailag megkötött víz eltávozása után a poliszacharid degradációja és az EDEA forrása játszódik le. A TG és derivatív termogravimetriás (DTG) görbék segítségével a következő forráspontot (EDEA) és degradációs hőmérsékleteket (M-HyA, cl-M-HyA/75\%) határoztuk meg: $\mathrm{T}_{\mathrm{f}}=109{ }^{\circ} \mathrm{C}$ (EDEA), $\mathrm{T}_{\mathrm{d}}=205{ }^{\circ} \mathrm{C}(\mathrm{M}-\mathrm{HyA}), \mathrm{T}_{\mathrm{d}}=167{ }^{\circ} \mathrm{C}$ (cl-M-HyA/75\%). A kezdeti M-HyA makromolekulához képest a cl-M-HyA/75\% mintánál látható hömérséklet csökkenését a poliszacharidban kialakuló keresztkötések okozhatják. A keresztkötő EDEA ágens 
forráspontjánál és a M-HyA $\sim 603{ }^{\circ} \mathrm{C}$-nél megfigyelhetö tömegváltozások a cl-M-HyA/75\% TG görbéjén nem jelennek meg, így kijelenthető, hogy a tisztítás és liofilizálás után a minták szennyeződést nem tartalmaznak. A DSC vizsgálatok alapján a M-HyA bomlásának exoterm csúcs maximuma $222{ }^{\circ} \mathrm{C}$-on, illetve az EDEA endoterm forráspontjához/bomlásához tartozó endoterm csúcs minimuma $236{ }^{\circ} \mathrm{C}$ hőmérsékleten jelenik meg. Az EDEA esetén a TG -hez viszonyított nagymértékű hőmérséklet eltolódás a zárt cellában történő mérés miatt következhet be. A cl-M-HyA/75\% degradációs hőmérséklete $\left(\mathrm{T}_{\mathrm{d}, \max }=216{ }^{\circ} \mathrm{C}\right)$ exoterm sajátsággal bír, amit feltételezhetően a mintában megtalálható keresztkötésben lévő M-HyA indukál.
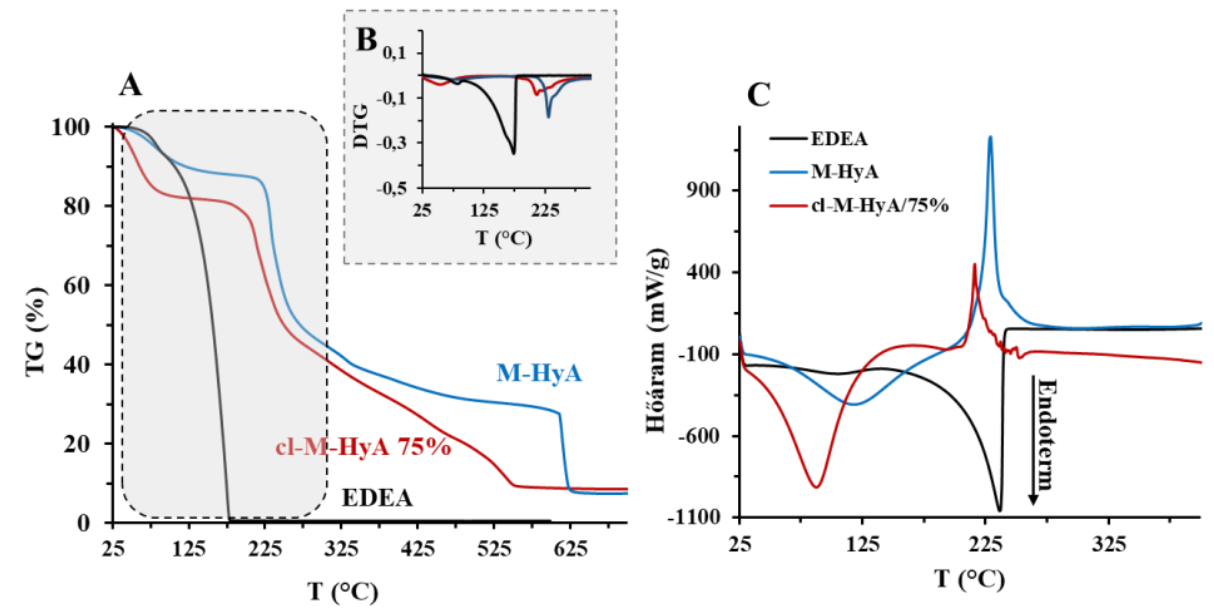

28. ábra: A 75\% -ban keresztkötött M-HyA (cl-M-HyA/75\% (piros)), a keresztkötő EDEA komponens (fekete) és a M-HyA (kék) (A) TG, (B) DTG és (C) DSC görbéi

A keresztkötött M-HyA származékok karakterizálása után meghatároztuk a szintézis során keletkezett részecskék hidrodinamikai átmérőjét. A 29.A. ábrán bemutatott méreteloszlási görbéken jól látható, hogy a keresztkötés mértékének növekedésével a részecskeméret és a polidiszperzitás szisztematikusan nő $\mathrm{d}_{\mathrm{DLS}} \approx 45 \mathrm{~nm}$-ről (cl-M-HyA/50\%) $\mathrm{d}_{\mathrm{DLS}} \approx 110 \mathrm{~nm}$-ig (cl-M-HyA/100\%). A mintákról TEM felvételeket is készítettünk, amelyek közül egy a cl-M-HyA/100\% -nál rögzített képet a 29.B. ábrán mutatunk be, ahol kapott részecskéméret változások a DLS mérésekkel összhangban vannak (29.C. ábra). A $\zeta$-potenciál értékek vonatkozásában a magasabb keresztkötési arányoknál a részecskék egyre negatívabb értéket vesznek fel (cl-M-HyA/50\%: $\zeta=-13,8 \pm 0,1 \mathrm{mV}$, cl-M-HyA/75\%: $\zeta=-$ $20,0 \pm 2,1 \mathrm{mV}, \mathrm{cl}-\mathrm{M}-\mathrm{HyA} / 100 \%: \zeta=-23,6 \pm 0,6 \mathrm{mV})$. 


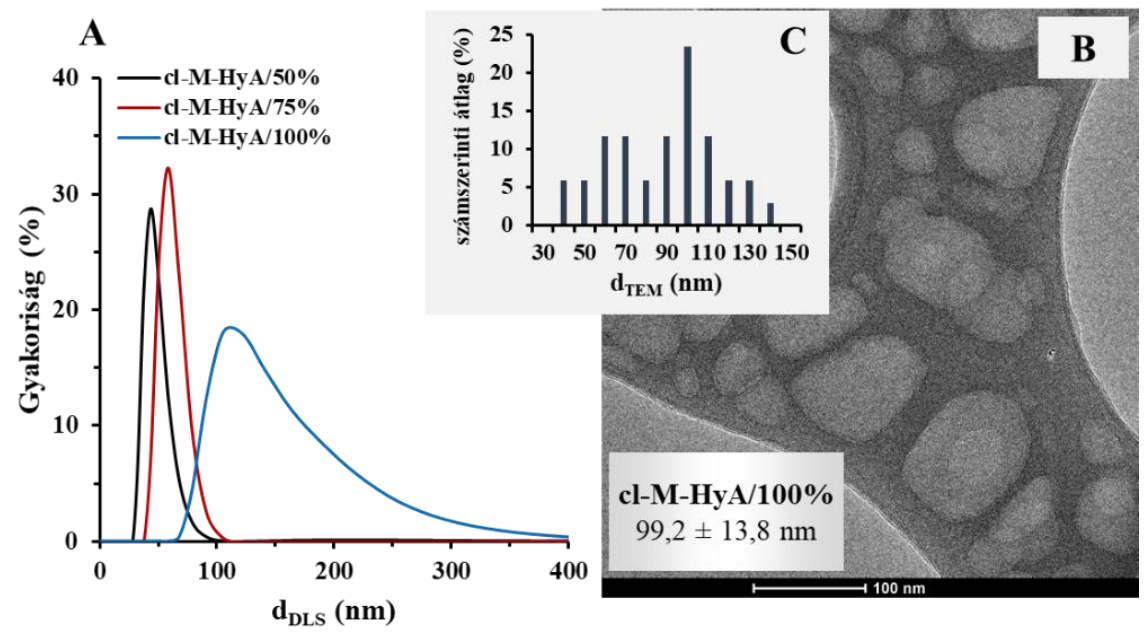

29. ábra: (A) A különböző mértékben keresztkötött M-HyA nanorészecskék méreteloszlása, illetve (B) cl-M-HyA/100\% részecskékröl készült TEM felvétel és (C) a meghatározott számszerinti méreteloszlás

\subsubsection{CTAB -dal neutralizált HyA nanorészecskék elöállitása és karakterizálása}

Jól ismert, hogy a kationos felületaktív anyagok és az anionos M-HyA között kialakuló elektrosztatikus kölcsönhatások révén jól definiált komplex rendszerek állíthatóak elő [59,106]. Annak érdekében, hogy a térhálósított polimerhez hasonló kolloidális komplexeket, mint gyógyszerhordozó rendszereket állíthassunk elö, az általunk felhasznált M-HyA poliszacharidot $\left(\mathrm{M}_{\mathrm{w}}=200-500 \mathrm{kDa}\right)$ részlegesen és teljesen neutralizáltuk pozitív töltésü CTAB felületaktív anyag segítségével (30. ábra).

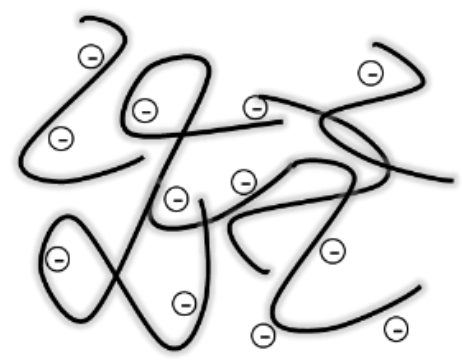

Lineáris hialuronsav láncok (HyA)

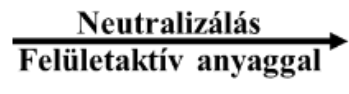

$\oplus$ CTAB

30. ábra: A HyA CTAB-dal történő neutralizálásának sematikus ábrája

A M-HyA/CTAB komplex rendszerek kialakítása előtt fontos a poliszacharidfelületaktív anyag közötti elektrosztatikus kölcsönhatások kvantitatív megismerése. A MHyA neutralizációs tulajdonságait első lépésben konduktometriás és ITC módszerekkel tanulmányoztuk. Előmérésként meghatároztuk a CTAB $c m c$ értékét M-HyA jelenléte nélkül, 
ahol mind a konduktometriával, mind a ITC -vel hasonló értéket kaptunk (konduktometria: $\mathrm{cmc}_{\mathrm{CTAB}}=0,94 \pm 0,01 \mathrm{mM}$; ITC: $\left.\mathrm{cmc}_{\mathrm{CTAB}}=0,93 \pm 0,03 \mathrm{mM}\right)$ (31.A. és 32.A. ábra). Ezek a szakirodalomban fellelhető adatokkal nagyon jó egyezést mutatnak [137,138]. A méréseket megismételve 0,1 mg/mL koncentrációjú M-HyA oldatban az adott $\mathrm{cmc}$ értékek 1,16 $\pm 0,02$ $\mathrm{mM}$-re tolódnak el (31.B. és 32.B. ábra). Az eredményekből megállapítható, hogy a rendszerben lejátszódó folyamatok első lépéseként a negatív töltésű M-HyA poliszacharidot

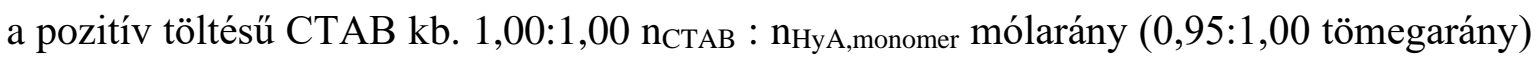
mellett neutralizálja, melynek befejeződése után a stabilizátor micellaképződése kezdődik el.
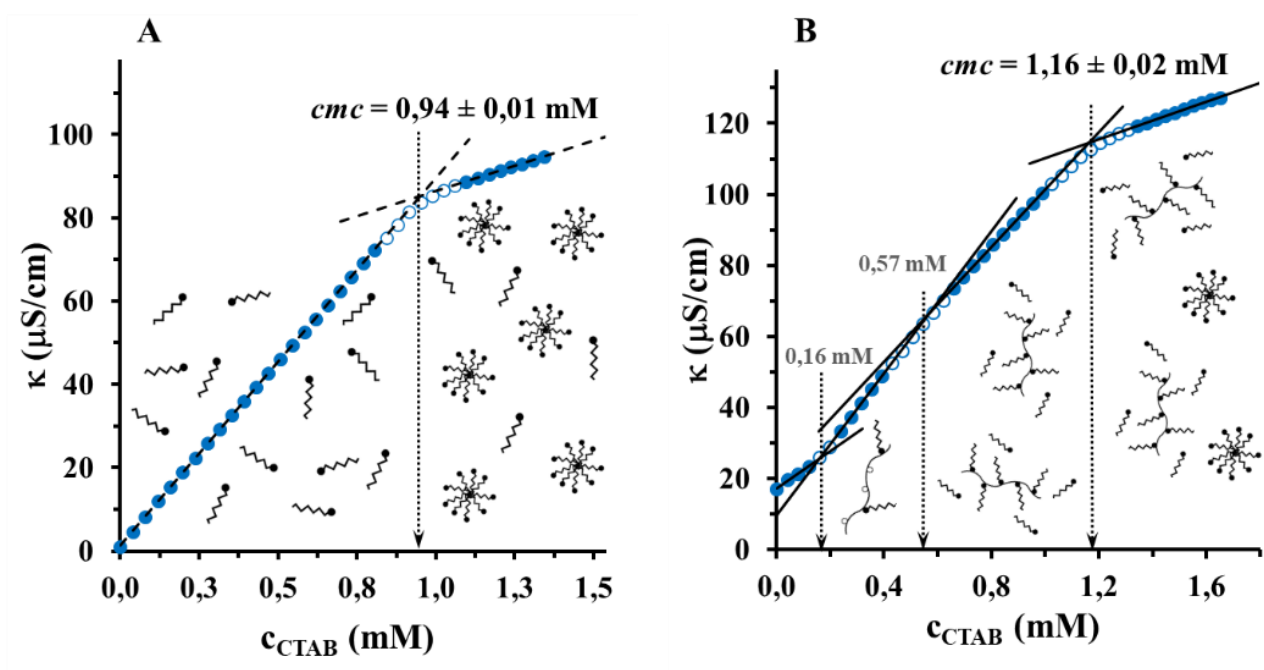

31. ábra: (A) M-HyA nélküli és (B) M-HyA tartalmú rendszerekben a CTAB $\mathrm{cmc}$ értékének meghatározása konduktometriás módszerrel $\left(\mathrm{c}_{\mathrm{HyA}}\right.$, kezdeti $\left.=0,1 \mathrm{mg} / \mathrm{mL}\right)$

J. Krouská és M. Pekař 10 kDa -tól 1750 kDa molekulatömeggel rendelkező HyA és CTAB/TTAB között kialakuló kölcsönhatásokat már vizsgálták nagyfelbontású ultrahangos spektroszkópiával [139]. A rendszerükön végzett mérések alapján a kritikus aggregációs koncentráció ( $c a c$ ) 1:1 körüli töltési arányok beállta esetében figyelhető meg. Ezt egy későbbi publikációjukkal még inkább megerősítették [140]. Azonban fontos megjegyezni, hogy az eredményeiket $c m c$ feletti koncentrációknál kapták, ahol a micellák képződése jelentősen befolyásolhatja az adatokat. Ennek ismeretében a $c a c$, és ezzel a lineáris HyA ekvivalens töltésének pontos meghatározásához a ITC mérésket kisebb koncentrációjú felületaktív anyag esetében is elvégeztük $\left(\mathrm{c}_{\mathrm{HyA}}=0,1 \mathrm{mg} / \mathrm{mL}, \mathrm{C}_{\mathrm{CTAB}}=5 \mathrm{mM}\right)$. A 32.A. ábrán látható, hogy a CTAB $c m c$ értéke mellett a töltéskompenzálás mértékére meghatározott arányok is jó egyezést mutatnak a konduktometriás adatokkal. 

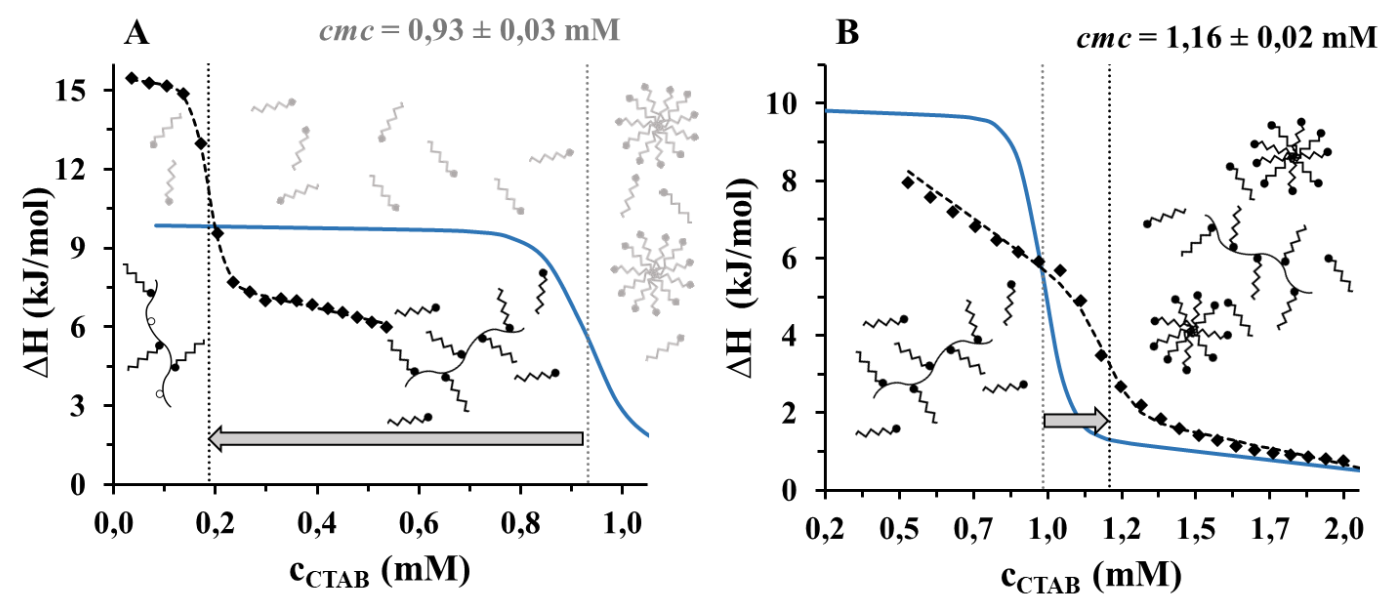

32. ábra: Az ITC mérésekböl nyert kalorimetriás entalpia görbék (A) $5 \mathrm{mM}$ és (B) $12 \mathrm{mM}$ koncentrációjú CTAB titráló oldatok mellett $\left(\mathrm{T}=25^{\circ} \mathrm{C}, \mathrm{c}_{\mathrm{HyA}, \mathrm{kezdeti}}=0,1 \mathrm{mg} / \mathrm{mL}\right)(\mathrm{a}$ HyA nélküli mérést a kék vonal jelzi)

A HyA áttöltését jelző inflexióspont 0,2 $\pm 0,01 \mathrm{mM}$ koncentrációnál (a konduktometriás mérések esetén $\sim 0,16 \mathrm{mM}$ megjelenő változásnál (31.B. ábra)) jelenik meg, ami mólarányok szerint áltagosan 1,2:1,0 értéket jelent. Vizsgálatainkkal megerősítettük, hogy a M-HyA felületaktív anyaggal történő töltéskompenzálás aránya a CTAB koncentrációjával szabályozható.

Az ITC és konduktometriás mérések mellett a M-HyA látszólagos viszkozitását is meghatároztuk állandó nyírósebességen elvégzett reológiai mérésekkel, melyek eredményét a 33. ábra foglalja össze.

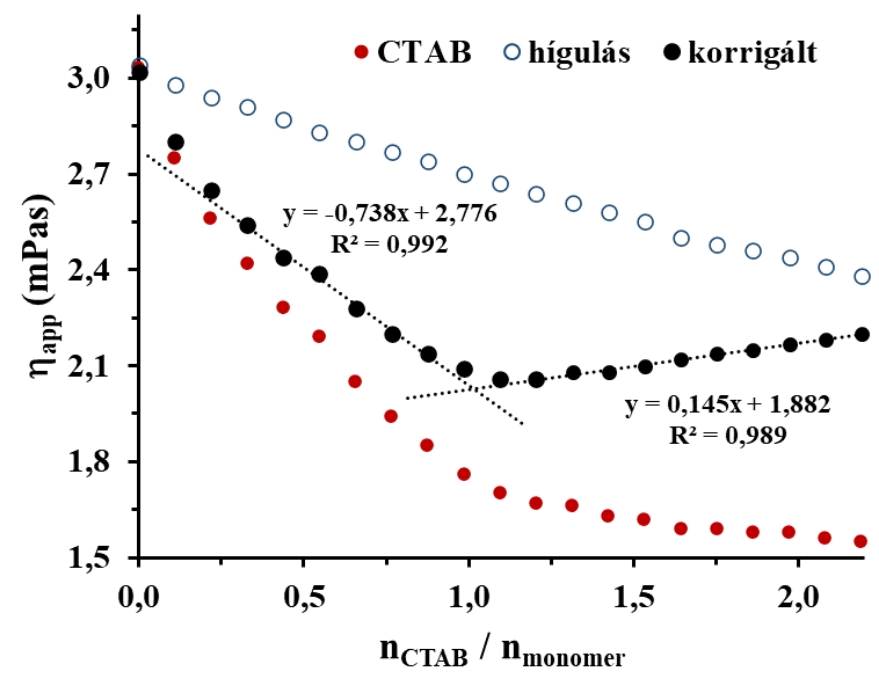

33. ábra: M-HyA látszólagos viszkozitási görbéje állandó nyírási sebesség mellett $\left(\mathrm{c}_{\mathrm{HyA}}\right.$, kezdeti= $0,1 \mathrm{mg} / \mathrm{mL}, \mathrm{c}_{\mathrm{CTAB}}$, titráló oldat= $25 \mathrm{mM}$ ) 
A módszer előnye, hogy a viszkozitáson kívül a vizsgált minta szerkezeti változásait is azonosíthatjuk. A CTAB/M-HyA(monomer) mólarány folyamatos növekedésével a látszólagos viszkozitás értéke fokozatosan csökken. Annak érdekében, hogy a CTAB okozta szerkezeti hatásokat igazoljuk szükséges a rendszer hígulásával korrekciót végezni, ahogyan azt a 33. ábra is mutatja. Az így meghatározott látszólagos viszkozitás értékek szerint, a rendszerben történő szerkezeti változások (feltételezhetően az aggregációs folyamatok) okán, a CTAB mennyiségének növelése mellett megfigyelhető kezdeti csökkenést egy törés szakítja meg, amelyet folytatólagosan már egy lineárisan növekvő szakasz követ. A szakaszokra illesztett egyenesek metszéspontjából meghatározható a M-HyA poliszacharidhoz rendelhető áttöltési pont. A számolások alapján a M-HyA neutralizálás

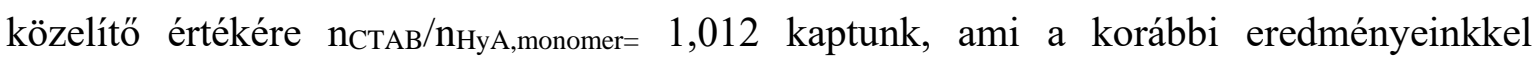
(konduktometria, ITC) jó összhangban van.

A M-HyA/CTAB közötti kölcsönhatások karakterizálását követően a komplex rendszer $\zeta$-potenciálját és hidrodinamikai átméröjét a m $\mathrm{m}_{\mathrm{CTAB}}: \mathrm{m}_{\mathrm{HyA} \text {,monomer tömegarány }}^{4}$ függvényében tanulmányoztuk (34. ábra), mely során megállapítottuk, hogy a részecskék méretében és stabilitásában történő változások a kalorimetriás és a vezetőképesség mérések eredményeivel jól összevethetőek. A teljes áttöltési pont eléréséig (0,95:1,0 tömegarány) a M-HyA alapú részecskék $\zeta$-potenciálja negatív értéket vesz fel.
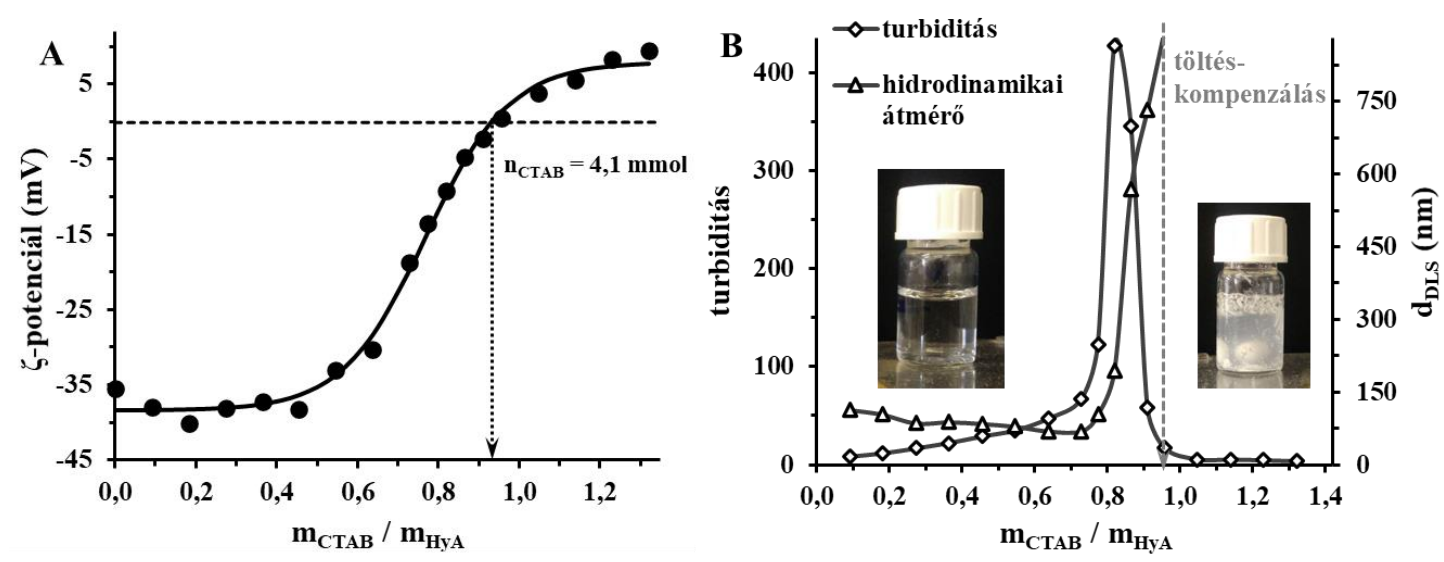

34. ábra: M-HyA/CTAB rendszer (A) ל- potenciál, (B) turbiditás és hidrodinamikai

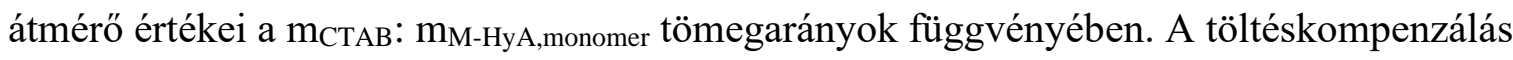
előtt $\left(\mathrm{m}_{\mathrm{CTAB}} / \mathrm{m}_{\mathrm{HyA}}\right.$,monomer $\left.=0,2\right)$ és után $\left(\mathrm{m}_{\mathrm{CTAB}} / \mathrm{m}_{\mathrm{HyA}}\right.$,monomer $\left.=0,95\right)$ készített minták reprezentatív fotói (B) ( $\mathrm{c}_{\mathrm{HyA}}=0,2 \mathrm{mg} / \mathrm{mL}, \mathrm{c}_{\mathrm{CTAB}}=0,0-0,26 \mathrm{mg} / \mathrm{mL}$, PBS közeg)

\footnotetext{
4 A korábban alkalmazott $\mathrm{n}_{\mathrm{CTAB}} / \mathrm{n}_{\mathrm{HyA}(\text { monomer) }}$ mólarányokat azért váltottuk át $\mathrm{m}_{\mathrm{CTAB}} / \mathrm{m}_{\mathrm{HyA}}$ tömegarányokra, mert a CTAB és a HyA egy monomer egységének móltömege közel megegyezik.
} 
Efölött a rendszer stabilitása jelentősen lecsökken, amit a turbidimetriás mérések is megerősítenek. A 34.B. ábrán látható, hogy a 0,80 tömegarányig átlagosan 50-130 nm közötti hidrodinamikai átmérő érhető el. Megállapítható továbbá, hogy 0,80 tömegarány felett a rendszerben lejátszódó M-HyA neutralizálásának köszönhetően a hidrodinamikai átmérő $50 \mathrm{~nm}$-ről $750 \mathrm{~nm}$-re nő. A turbiditást nézve a 0,80-0,95 tömegarányok közt jelentős növekedés figyelhető meg, amit a nagyfokú aggregáció miatt kialakuló fázisszeparáció (oldószer fázis/szilárd M-HyA/CTAB aggregátumok) hirtelen lecsökkent. Ebből látható, hogy feleslegben lévő CTAB jelenlétében keletkező részecskék gyógyszerhordozóként való felhasználhatóságát nézve nem optimálisak, így a M-HyA ezen a tartományon nem alkalmazható hordozóként. Eredményeinket összevetve az irodalmi adatokkal megállapítható, hogy átlagosan kisebb mérettel rendelkező részecskéket tudtunk előállítani. T. Krutišová és munkatársai korábban már vizsgálták a CTAB -ból, illetve $\mathrm{Mw}_{\mathrm{w}}=117$ és 1670 kDa molekulatömeggel rendelkező HyA -ból felépülő nanorészecskéket, viszont csak 100 nm feletti részecskeméreteket kaptak [141]. T. Pilgrova és M. Pekař munkája során a CTAB/Septonex és HyA ( $\left(\mathrm{M}_{\mathrm{w}}=13 \mathrm{kDa}, 117 \mathrm{kDa}\right.$ és $\left.1635 \mathrm{kDa}\right)$ összetételü rendszereket turbidimetriás és DLS módszerekkel tanulmányoztak, ahol azonban a CTAB -dal összevethető szerkezetủ Septonex (karbetopendecínium bromid) stabilizátorral és HyA -val $\left(\mathrm{M}_{\mathrm{w}}=13 \mathrm{kDa}, 117 \mathrm{kDa}\right)$ az általunk meghatározottakhoz képest jóval nagyobb, 200 - 500 nm -es részecskéket tudtak előállítani [142].

\subsubsection{HyA alapú rendszerek reológiai tulajdonságai}

Az Irodalmi áttekintésben (2.3.2. alfejezet) korábban már részleteztük, hogy a HyA alapú rendszerek folyási tulajdonságainak, ezáltal a külső erők hatásra bekövetkező szerkezeti változásainak megismerése érdekében a reológiai mérések kiemelkedő szereppel bírnak. Azonban fontos megjegyezni, hogy a hordozó rendszereknél releváns nagyon kis koncentrációjú HyA oldataival kapcsolatban kevés információ található. Ezt figyelembe véve, meghatároztuk a M-HyA viszkozitási tulajdonságait szélesebb koncentráció intervallumon $(0,05-50 \mathrm{mg} / \mathrm{mL})$ (35. ábra). A koncentráció függvényében detektált viszkozitási görbéket Bingham- (5. egyenlet) és Carreau-Yasuda (6. egyenlet) modellel illesztettük, melyek eredményeit a 9. táblázatban összesítettük. A rögzített görbéken jól látható, hogy alacsonyabb M-HyA koncentrációjú oldatok Newtoni viselkedést mutatnak, ami a koncentráció növelésével pszeudopasztikusra, majd viszkoelasztikusra vált át. Nagyon híg polimer (molekuláris) oldatoknál a viszkozitás változása kiemelten a poliszacharid áramlási rendszerbeli viselkedésével (pl. deformációs, orientációs) köthető össze. 

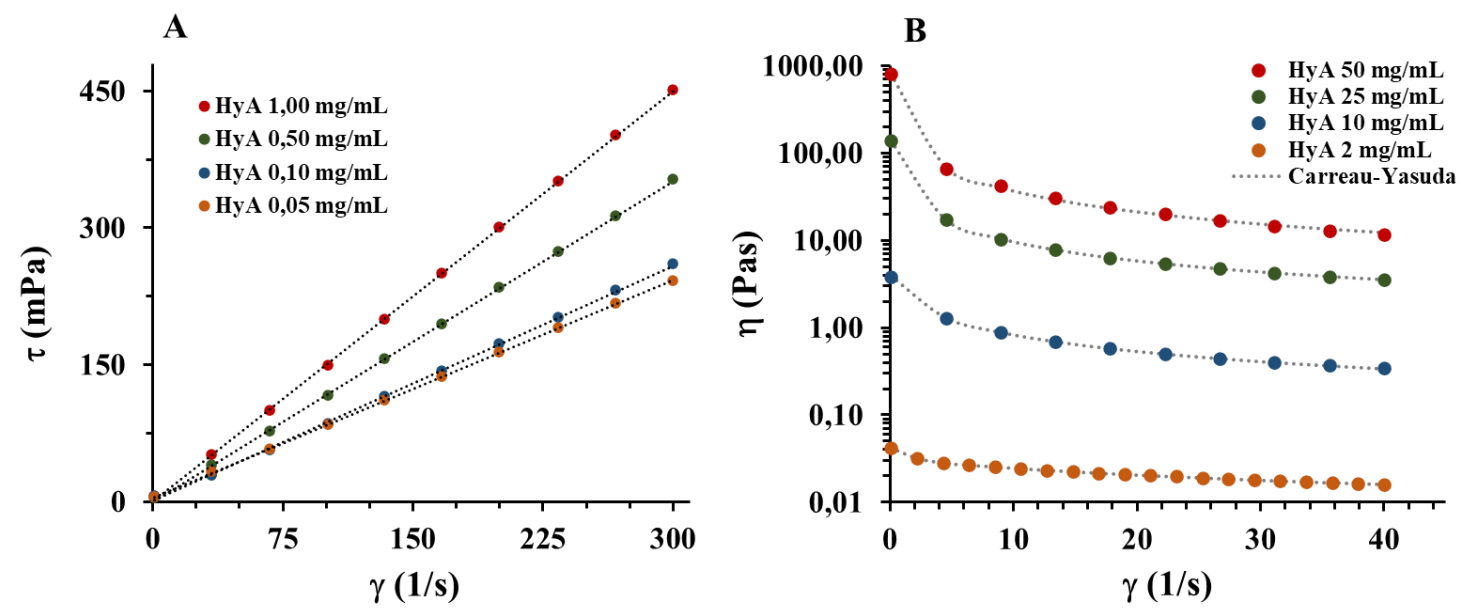

35. ábra: (A) Alacsony koncentrációjú (0,05-1,0 mg/mL) M-HyA oldatok nyírófeszültségének és $(\mathbf{B})$ a nagyobb koncentrációjú $(2-50 \mathrm{mg} / \mathrm{mL})$ oldatok/gélek viszkozitásának változása a nyírósebesség függvényében

9. táblázat: A különböző koncentrációjú M-HyA/CTAB oldatok viszkozitás és nyírófeszültség görbéire illesztett Bingham és Carreau-Yasuda modellekből meghatározott plasztikus viszkozitás $\left(\eta_{\mathrm{pl}}\right)$, Bingham-féle folyáshatár $\left(\tau_{\mathrm{B}}\right)$, nulla- nyírási viszkozitás $\left(\eta_{0}\right)$ és végtelen-nyírási viszkozitás $\left(\eta_{\infty}\right)$ értékek

\begin{tabular}{ccccc}
\hline $\mathbf{c}_{\mathbf{H y A}}(\mathbf{m g} / \mathbf{m L})$ & $\boldsymbol{\eta}_{\mathbf{p l}} \pm \mathbf{S D}(\mathbf{m P a} \mathbf{s})$ & $\boldsymbol{\tau}_{\mathbf{B}} \pm \mathbf{S D}(\mathbf{P a})$ & $\boldsymbol{\eta}_{\mathbf{0}} \pm \mathbf{S D}(\mathbf{P a} \mathbf{s})$ & $\boldsymbol{\eta}_{\infty} \pm \mathbf{S D}(\mathbf{P a} \mathbf{s})$ \\
\hline 0,05 & $0,792 \pm 0,006$ & - & - & - \\
0,10 & $0,872 \pm 0,000$ & - & - & - \\
0,50 & $1,180 \pm 0,007$ & - & - & - \\
1,00 & $1,508 \pm 0,007$ & - & - & - \\
2,00 & $10,76 \pm 0,211$ & $0,217 \pm 0,007$ & $0,046 \pm 0,003$ & $0,000 \pm 0,000$ \\
10,00 & $128,3 \pm 8,391$ & $8,493 \pm 0,283$ & $4,368 \pm 0,010$ & $0,010 \pm 0,010$ \\
25,00 & $1126 \pm 159,5$ & $96,44 \pm 5,377$ & $138,9 \pm 0,019$ & $0,282 \pm 0,019$ \\
50,00 & $1328 \pm 265,7$ & $416,4 \pm 8,958$ & $815,5 \pm 1,649$ & $0,312 \pm 0,039$ \\
\hline
\end{tabular}

A nagyobb molekulatömegü és koncentrációjú polimer oldatoknál a nyírási sebesség növekedésével a viszkozitás csökkenése figyelhető meg [60,98,143]. Ez a konklúzió az 1 $\mathrm{mg} / \mathrm{mL}$ koncentrációnál töményebb M-HyA oldatoknál is levonható. A viszkozitásban megfigyelhető változás egy alternatív magyarázata a lineáris polimer láncok nagy koncentráción megvalósuló „„összegombolyodásához” köthető [91]. A gombolyagon belül feltételezhetően kialakuló másodrendű kölcsönhatások száma, melyek kialakulása a hőmozgástól is jelentősen függ, az egyre növekvő nyírósebesség következtében csökkenhet, amely kisebb viszkozitási értékeket eredményez. Ezt a változást tovább erősítheti a gombolyag lazulása/megszünése eredményeként megfigyelhető áramlási irány szerinti orientáció. 
A tömény M-HyA oldatok viszkoelasztikus viselkedésének megismeréséhez oszcillációs méréseket végeztünk $10 \mathrm{~Hz}$ állandó oszcillációs frekvencián, melynek eredményét a 36. ábra foglalja össze. A tárolási (G’) és veszteségi (G”) modulus értékek változásából meghatároztuk a gélek elasztikus/viszkózus sajátságát. Az alacsony nyírási deformációnál minden esetben a gélek elasztikus karaktere kerül előtérbe, míg magasabb értékeknél a viszkózus sajátság dominál ( $G^{\prime}<G$ ”). A 0,1-10,0\% tartományon a G' és G” nem változik, így a nyírási deformáció nincs hatással a belső súrlódási viszonyokra. $10 \%$ fölött a plasztikus /pszeudo-plasztikus viselkedésnek megfelelöen a modulus értékek nem lineárisan változnak. Magas deformációknál a folyási pontot $\left(G^{\prime}=G^{\prime \prime}\right)$ követően a viszkózus viselkedés kerül előtérbe. A folyási pontok és kezdeti G”/G’ arányából (a 4.3.1 alfejezet szerint $\tan \delta$ ) meghatározott fáziseltolódás értékei a 36.B. ábrán láthatóak. A koncentráció növelésével a folyási pont hirtelen megnő, míg a fáziseltolódás csökken. A fáziseltolódás csökkenése a HyA alapú géles oldatoknál tapasztaltakat szerint [98,144], a rendszer viszkózus viselkedése egyre elasztikusabbá válik a koncentráció növekedésével.
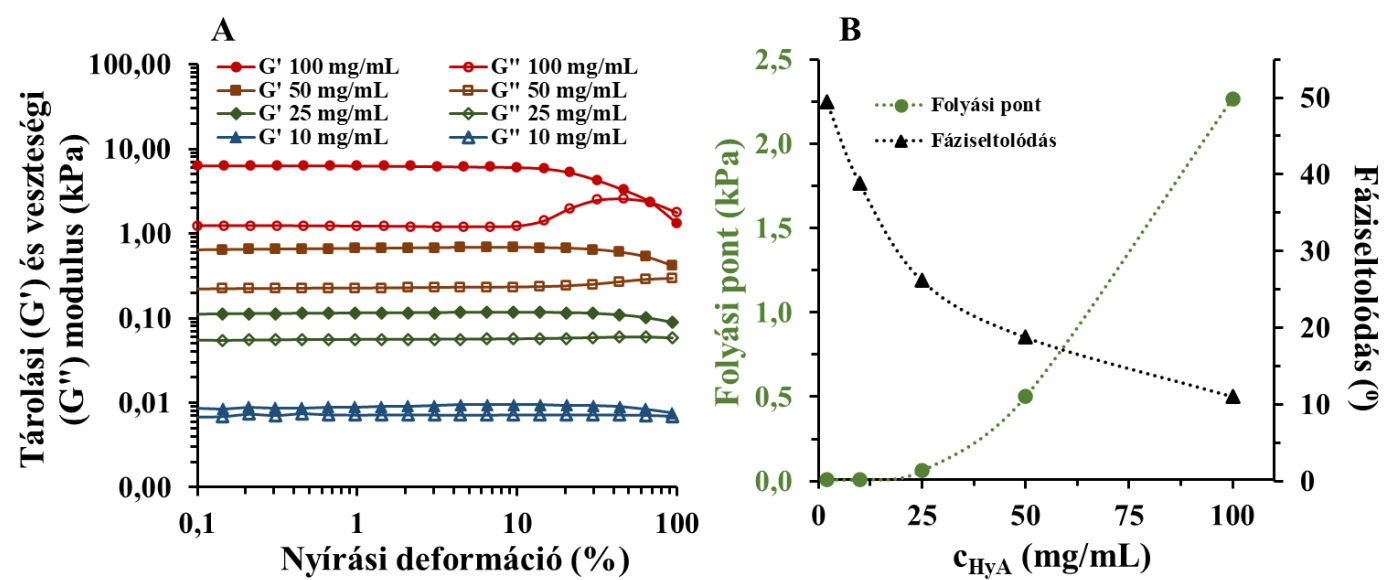

36. ábra: M-HyA hidrogélek (A) nyírási deformáció és (B) koncentráció függvényében meghatározott viszkoelasztikus paraméterei (A: tárolási modulus $\left(\mathrm{G}^{\prime}\right)$, veszteségi modulus (G”); B: folyási pont, illetve fáziseltolódás a kezdeti G’ és G” értékek alapján)

A szakirodalomban talált CTAB-dal neutralizált és térhálósított HyA poliszacharidot frekvencia sepréses oszcillációs módszerrel vizsgálták [97,105]. Sz. Berkó és munkatársai meghatározták, hogy a térhálósított HyA esetén a frekvencia növelésével a gélek kiemelten viszkózus jellege elasztikusra vált [105]. Mivel csak a kiindulási és a $25 \%$-ban keresztkötött mintát tanulmányozták, ezért jelentős konzekvenciát a térhálósítás mértékének hatásáról nem lehet levonni. T. Venerová és M. Pekař különböző molekulatömegü HyA, CTAB -dal történő neutralizálásánál, az előzővel megegyezően, kezdetben a viszkózus sajátság 
dominanciáját figyelték meg [97]. Az általunk is vizsgált kisebb molekulatömegű (300 kDa) HyA esetében nagyobb CTAB koncentrációknál folyási pontot nem tudtak meghatározni, illetve a méréseket kis kiindulási HyA koncentrációk és nagy mennyiségű stabilizátor felesleg mellett végezték el.

Ezt figyelembe véve, meghatároztuk a CTAB -dal neutralizált M-HyA és a cl-M-HyA viszkoelasztikus tulajdonságait a nyírási deformáció függvényében. A M-HyA/CTAB rendszernél $50 \mathrm{mg} / \mathrm{mL}$ kiindulási M-HyA koncentrációt állítottunk be, ahol a neutralizálás mértéke százalékosan 0-100\% között változott. A CTAB -dal részlegesen neutralizált MHyA esetén a korábbi eredményeinkhez hasonló változásokat tapasztaltunk. Alacsonyabb deformációknál elasztikus, míg magasabb értékeknél a veszteségi modulus ( $G$ ” > G') és így a viszkózus viselkedés dominál (37. ábra).

A

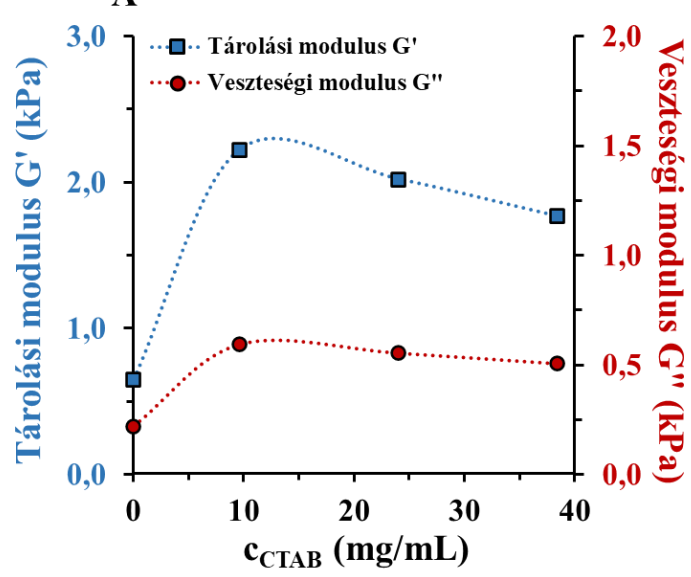

B

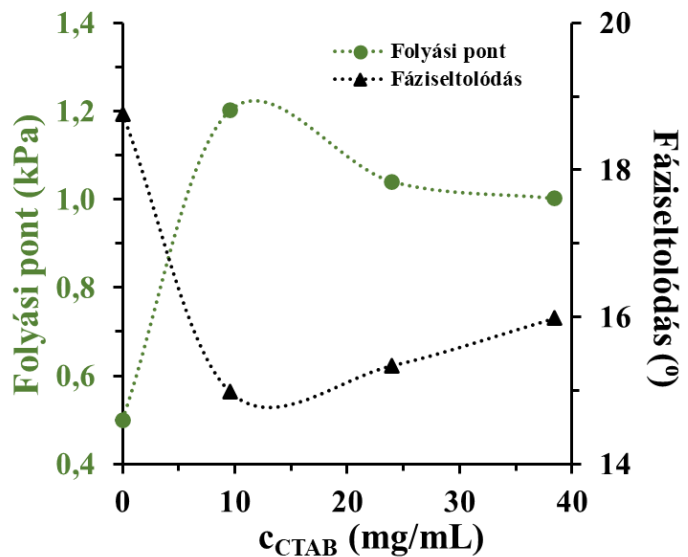

37. ábra: CTAB -dal neutralizált M-HyA gélek amplitúdó sepréses oszcillációs módszerrel meghatározott reológiai paraméterei (A: kezdeti tárolási (G’) és veszteségi (G”) modulus; B: folyási pont és fáziseltolódás) ( $\mathrm{C}_{\mathrm{HyA}}=50 \mathrm{mg} / \mathrm{mL}$ )

A kezdeti deformációknál a G’ és a G” ismételten konstans értéket mutat. Az egyes szakaszokra illesztett egyenesek tengelymetszetéből meghatározott tárolási és veszteségi modulust a 37.A. ábrán mutatjuk be. Ezek ismeretében meghatároztuk a fáziseltolódás kiinduló értékeket (37.B. ábra). $50 \mathrm{mg} / \mathrm{mL}$ M-HyA koncentráció beállítása mellett, ha a stabilizátor koncentrációja $<10 \mathrm{mg} / \mathrm{mL}$, akkor a Newtoni viselkedés egyre elasztikusabbá válik, míg magasabb koncentrációknál (>10 mg/mL) a viszkózus sajátság kezd megerősödni. A 37.B. ábra alapján a folyási pont a fáziseltolódással ellentétben a kezdeti hirtelen növekedést követően csökkenő tendenciát mutat. Hasonló körülmények között a térhálósított M-HyA mintákat is megvizsgáltuk (38. ábra). 
$\mathbf{A}$

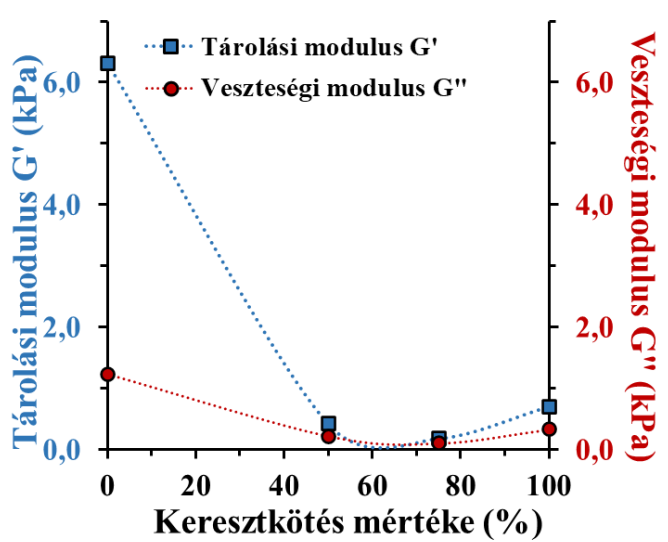

B

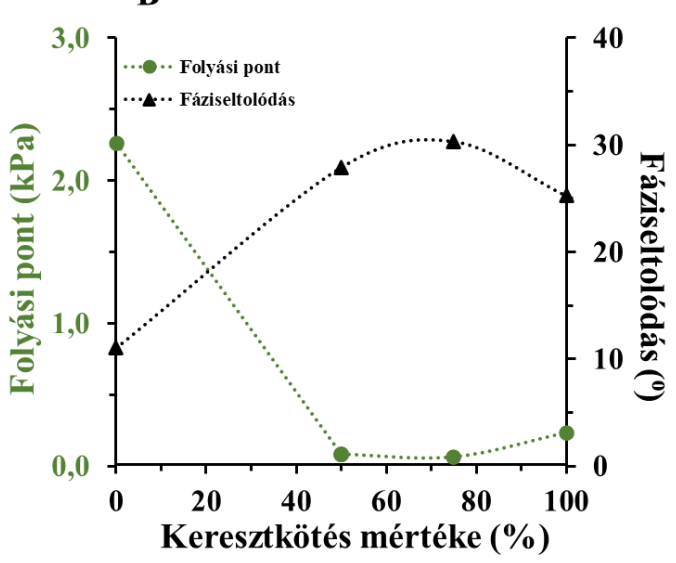

38. ábra: Térhálósított HyA gélek amplitúdó sepréses oszcillációs módszerrel meghatározott reológiai paraméterei (A: kezdeti tárolási (G’) és veszteségi (G”) modulus; B: folyási pont és fáziseltolódás)

A kezdeti lineáris szakasz tárolási és veszteségi modulusokhoz tartozó konstans értékei a keresztkötés jelenlétében jelentősen csökkennek. Magasabb deformációknál a korábbi rendszerekkel megegyezően a veszteségi modulus kerül előtérbe. A meghatározott fáziseltolódás a neutralizált polimerekkel ellentétben nagymértékben növekszik. Ezek alapján a kezdeti elasztikusból egyre viszkózusabb viselkedés figyelhető meg. Összevetve a korábbi eredményeket megállapítható, hogy a keresztkötés jelenléte korlátozza a koherens rendszerek kialakulását. Azonos hatás a M-HyA/CTAB rendszernél csak magasabb stabilizátor koncentrációknál figyelhető meg.

A kiindulási és a módosított (térhálósítás, neutralizálás) HyA poliszachariddal kapcsolatos viszkozitási tulajdonságok ismerete nagymértékben segíti a hatóanyag-tartalmú rendszerek kioldódási folyamatainak (pl. diffúzió, erózió) jellemzését. Ezek függvényében a következő lépésben a KP-tartalmú HyA alapú hordozókból a hatóanyag kioldódási tulajdonságait vizsgáljuk meg.

\subsubsection{HyA alapú rendszerek in vitro hatóanyag kioldódási tulajdonságai}

Munkánk során meghatároztuk a CTAB -dal hidrofóbizált és eltérő mértékben keresztkötött M-HyA alapú hordozó rendszerek hatóanyagleadó képességét. A mérések kivitelezéséhez modell vegyületként ketoprofent (KP) használtunk. A kioldódási méréseket $50 \%, 75 \%$ és $100 \%$-ban keresztkötött, illetve 20, 40 és $80 \%$-ban CTAB -dal neutralizált M-HyA alapú rendszereknél végeztük el (39. és M50. ábra). Minden esetben a kapszulázási hatékonyság 95,0-95,5 \% -os volt az alkalmazott KP vegyület esetén. A rögzített kioldódási görbék folytonos kioldódási profilt mutatnak. Összehasonlítva a kétféle rendszert 
megállapítható, hogy a cl-M-HyA alapú hordozók alkalmazásával a KP visszatartási képessége a vizsgált 7 órás időtartományon kisebb (39.A. ábra). Megállapítható továbbá, hogy a térhálósítás mértékének növelésével a visszatartás nő. A cl-M-HyA/100\% rendszer vonatkozásában 6 óra után a KP mennyiségének 80\% -a, míg cl-M-HyA/50\% esetén közel $100 \%$ felszabadul. Ezzel ellentétben a M-HyA/CTAB rendszereknél a $20 \%$-ban CTABdal neutralizált hordozónál $~ 60 \%$, míg magasabb értékeknél akár 20 \%-os hatóanyag felszabadulás is elérhető (39.B. ábra).

A

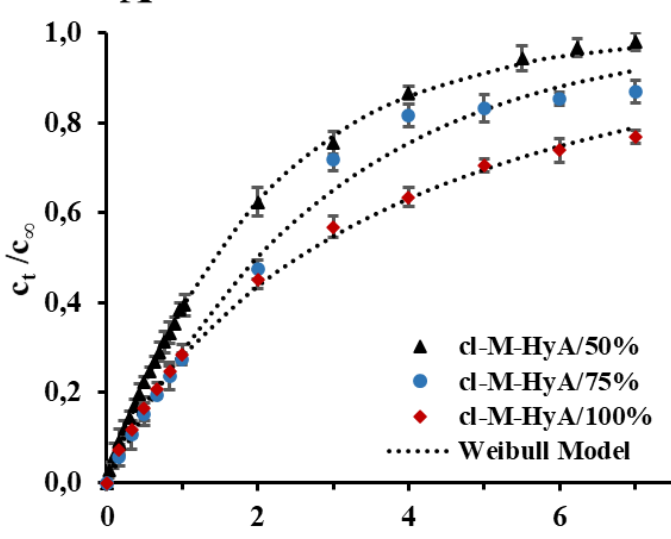

t (h)
B

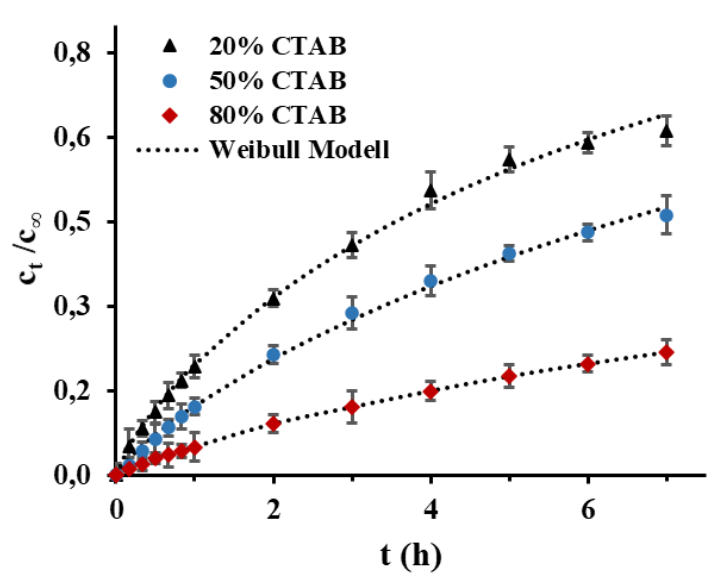

39. ábra: (A) A KP-tartalmú térhálósított- és (B) CTAB -dal neutralizált M-HyA hordozókból a KP kioldódási görbéi (pontokkal) és a mérési pontokra Weibull kinetikai modellel illesztett görbék (szaggatott vonal) $\left(\mathrm{T}=25^{\circ} \mathrm{C}, \mathrm{pH}=7,4,0,9 \mathrm{w} / \mathrm{w} \% \mathrm{NaCl}, \mathrm{PBS}\right.$ közeg)

A kioldódási görbéket különböző kinetikai modellekkel megillesztettük. A MHyA/CTAB rendszer esetén az $\mathrm{R}^{2}$ szerinti legjobb eredményt a Weibull, míg a második legjobbat a Korsmeyer-Peppas modell adta (10. táblázat). Ettől eltérően a térhálósított MHyA -nál a legjobb illesztést a Weibull és a második legjobbat elsőrendű modell mutatta. Attól függetlenül, hogy a Weibull modellhez képest a Korsmeyer-Peppas modell rosszabbul írja le a változásokat, az egyenlettel meghatározott kinetikai paraméterek a folyamatok jellemzése szempontjából jelentős információtartalommal bírnak. A hatóanyag felszabadulását jellemző diffúziós oldódási index (n) a CTAB-dal hidrofóbizált HyA esetén felületaktív anyag mennyiségének növelésével 0,60 (20\% CTAB), 0,70 (50\% CTAB) és 0,75 (80 \% CTAB) értékre emelkedik. Ebből látható, hogy a KP felszabadulását a diffúziós és eróziós folyamatok egyaránt szabályozzák (nem-Fick kioldódás). A korábbi $\zeta$ potenciállal, turbiditással és részecskemérettel kapcsolatos megfigyelések szerint a kisebb 
mennyiségben jelenlévő elektrosztatikusan adszorbeált CTAB -nál a hatóanyag felszabadulás gyorsabban és diffúzió kontrolláltabban játszódik le. A magasabb mólarányok mellett töltéskompenzált M-HyA poliszacharidnál a megnövekedett szerkezeti változások miatt a hatóanyag kioldódás lelassul és az erózió szerepe megnő.

A térhálósított polimereknél ez az effektus nem figyelhető meg. A diffúziós-oldódási index, függetlenül a keresztkötés mértékétől, áltagosan 0,55-0,61 értéket vesz fel, amely megközelíti a Fick I. féle folyamatokhoz tartozó $n=0,42$ határt, így a hatóanyag felszabadulásánál az erózió mellett a diffúzió dominál és ezt a befolyást a keresztkötés mértéke nem módosítja.

10. táblázat: A KP-tartalmú térhálósított és CTAB -dal neutralizált M-HyA rendszerek kioldódási görbéire illesztett kinetikai modellek (12-14. egyenlet) megfelelő paraméterei

\begin{tabular}{|c|c|c|c|c|c|c|c|c|}
\hline \multirow{2}{*}{$\begin{array}{l}\text { Modell } \\
\text { Minta }\end{array}$} & \multicolumn{2}{|c|}{ Elsőrendü } & \multicolumn{3}{|c|}{ Korsmeyer-Peppas } & \multicolumn{3}{|c|}{ Weibull } \\
\hline & $\begin{array}{c}\mathrm{k} \\
\left(\mathrm{min}^{-1}\right)\end{array}$ & $\mathrm{R}^{2}$ & $\begin{array}{c}\mathrm{k}_{\mathrm{m}} \\
\left(\mathrm{min}^{-\mathrm{n}}\right)\end{array}$ & $\mathrm{n}$ & $\mathrm{R}^{2}$ & $\mathrm{a}$ & $\mathrm{b}$ & $\mathrm{R}^{2}$ \\
\hline $20 \%$ CTAB & 0,16 & 0,9881 & 524 & 0,604 & 0,9819 & 0,0003 & 0,794 & 0,9971 \\
\hline $50 \%$ CTAB & 0,10 & 0,9892 & 149 & 0,698 & 0,9941 & 0,0002 & 0,821 & 0,9978 \\
\hline $80 \%$ CTAB & 0,04 & 0,9907 & 41 & 0,748 & 0,9989 & 0,0001 & 0,795 & 0,9995 \\
\hline cl-HyA/ 50\% & 0,50 & 0,9995 & 1401 & 0,554 & 0,9799 & 0,0001 & 0,991 & 0,9995 \\
\hline cl-HyA/ 75\% & 0,34 & 0,9977 & 698 & 0,613 & 0,9783 & 0,0001 & 1,010 & 0,9977 \\
\hline cl-HyA/ 100\% & 0,26 & 0,9901 & 1126 & 0,550 & 0,9886 & 0,0005 & 0,795 & 0,9986 \\
\hline
\end{tabular}

\subsection{Hialuronsav - kitozán poliszacharid alapú hordozó rendszerek előállítása és jellemzése}

\subsubsection{HyA-Chit között kialakuló elektrosztatikus kölcsönhatások jellemzése}

Doktori munkám során a CTAB -dal neutralizált M-HyA rendszerek tanulmányozása mellett megkíséreltük elektrosztatikus kölcsönhatások révén kialakítható hialuronsav - és kitozán $(\beta(1 \rightarrow 4)$ kötött $D$-glükozamin (deacetilezett) (és nem teljes deacetilezés esetén $N$ acetil- $D$-glükozamin) egységekből felépülő kationos poliszacharid [145]) alapú polielektrolit komplexek (PEC), mint potenciális hordozóként alkalmazható kolloid részecskék előállítását is. Jól ismert, hogy a poliszacharidok töltése a pH függvényében jelentősen változhat, ami egy hordozó rendszer esetében a kioldódási folyamatokat is befolyásolhatja [146]. Ezen kívül a PEC -ből kialakítható részecskék mérete és stabilitása is jelentősen eltérhet az előállításkor használt közeg pH -jától. Ezen folyamatok részletesebb 
megismerése érdekében, meghatároztuk a nagy molekulatömegü HyA -ból $\left(\mathrm{H}-\mathrm{HyA}: \mathrm{M}_{\mathrm{w}}=\right.$ 1500-1800 kDa) és a közepes molekulatömegü Chit -ból (M-Chit: $\mathrm{M}_{\mathrm{w}}=190-310 \mathrm{kDa}$ ) felépülő interpolimer komplexek pH szabályozott neutralizálással kapcsolatos sajátságait, melyhez első lépésben töltéstitrálási méréseket alkalmaztunk (40. ábra). A méréseket 2,00 $(\mathrm{pH}=2,53), 1,00(\mathrm{pH}=2,70), 0,727(\mathrm{pH}=2,77)$ és $0,500 \mathrm{~V} / \mathrm{V} \%$-os $(\mathrm{pH}=2,91)$ ecetsavas közegben végeztük el. A titrálási görbék kezdeti áramlási potenciáljának növekvő értékét a közegben jelen lévő ecetsav okozza. A M-Chit H-HyA -hoz történő folyamatos adagolásával egy kis mértékü lineáris növekedés figyelhető meg. Ezen a tartományon a H-HyA negatív töltése a M-Chit pozitív töltését olyan szinten tudja semlegesíteni, hogy a rendszer elektrosztatikus stabilitása csak kis mértékben változik. Az áttöltési pont elérése körül az áramlási potenciál értékek hirtelen ugrást mutatnak, mivel a nagy mennyiségben jelenlévő Chit töltését a HyA már nem tudja szabályozni. Ekkor az elektrosztatikus stabilitás lecsökken, amelyet a rendszer aggregációja követ. Az áttöltési pontot követően a nagy Chit túlsúly miatt az áramlási potenciál pozitív értéket vesz fel. Az ecetsav mennyiségének csökkenésével ( $\mathrm{pH}$ növelése) a lineáris szakasz kis mértékben elnyúlik, míg az áttöltési pont, a vártnak megfelelően, a nagyobb értékek felé eltolódik.
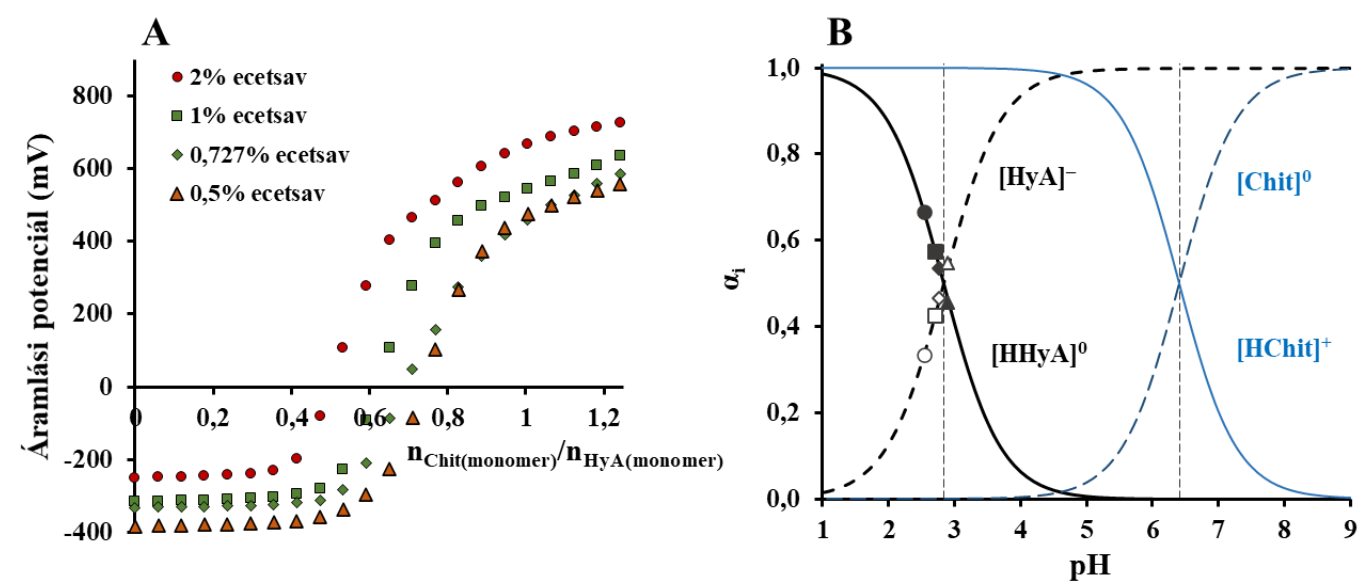

40. ábra: (A) A M-Chit-nal titrált H-HyA áramlási potenciál görbéi különböző ecetsavas közegben $\left(\mathrm{V}_{\text {HyA,titrálandó }}=10 \mathrm{~mL}, \mathrm{c}_{\mathrm{HyA}}\right.$,titrálandó $\left.=0,045 \mathrm{mg} / \mathrm{mL}, \mathrm{c}_{\text {Chit }}=0,091 \mathrm{mg} / \mathrm{mL}\right)$ és $(\mathbf{B})$ a poliszacharidok koncentrációeloszlás görbéi $\left(\mathrm{c}_{\mathrm{HyA}}=0,040 \mathrm{mg} / \mathrm{mL}, \mathrm{c}_{\mathrm{Chit}}=9,0 \mu \mathrm{g} / \mathrm{mL}\right)$. Az eloszlás görbéken szereplő szimbólumok az adott ecetsavas közeg pH értékét mutatják (•:

$$
\text { 2,00 V/V\%; } \mathbf{~ : ~ 1 , 0 0 ~ V / V \% ; ~ : ~ 0 , 7 2 7 ~ V / V \% ; ~} \mathbf{\Delta}: 0,500 \mathrm{~V} / \mathrm{V} \% \text { ) }
$$

A pontos áttöltési pontok meghatározásához a felvett titrálási görbéket a módosított Boltzmann egyenlettel (4. egyenlet) illesztettük. A számolások alapján a $0 \mathrm{mV}$-nál meghatározott monomer mólarányok $0,496 \pm 0,033(2,00 \%$ ecetsav $) ; 0,622 \pm 0,018(1,00$ 
$\%$ ecetsav); 0,696 $\pm 0,022(0,727 \%$ ecetsav $) ; 0,738 \pm 0,015(0,500 \%$ ecetsav $)$ folyamatosan nönek.

A PEC rendszerek áttöltési és viszkozitási tulajdonságait a 5.3.2 alfejezetben már megismert koncentráció függő, állandó nyírófeszültségen $(3001 / \mathrm{sec})$ elvégzett reológiai mérésekkel is elemeztük (41.A. ábra). Az eredményeket a rendszer hígulásával minden esetben korrigáltuk. A M-HyA/CTAB rendszerhez hasonlóan a látszólagos viszkozitás a MChit mennyiségének növelésével csökken, amelyet a H-HyA neutralizálása miatt lejátszódó folyamatok megtörnek. A szakaszokra illesztett egyenesek metszéspontjából származtatott töltéssemlegesítés, az áramlási potenciál méréseknél tapasztaltakkal megegyezően, a pH függvényében tolódik $\sim 0,438 \mathrm{n}_{\text {Chit }} / \mathrm{n}_{\mathrm{HyA}}$ monomer mólarányról $(2,0 \%$ ecetsav $) \sim 0,695$-re $(0,5 \%$ ecetsav $)$.

A

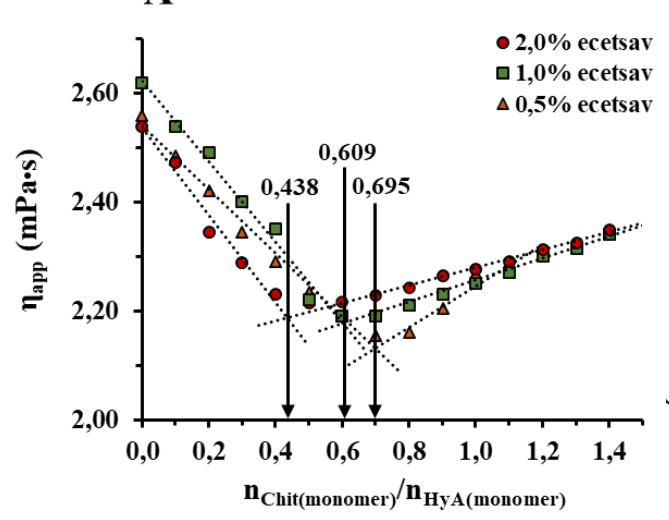

B

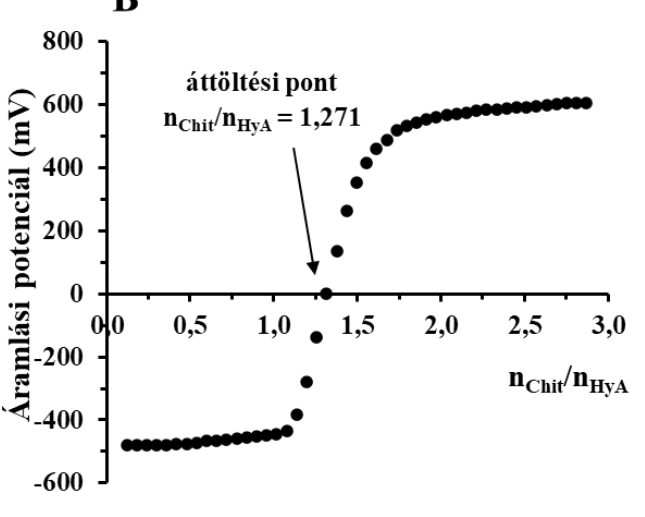

41. ábra: (A) A M-Chit - H-HyA rendszer látszólagos viszkozitásának változása a $\mathrm{n}_{\text {Chit }} / \mathrm{n}_{\text {HyA }}$ monomer arány és az ecetsav koncentráció függvényében $\left(\mathrm{V}_{\mathrm{HyA} \text {,titrálandó }}=19 \mathrm{~mL}\right.$,

$\left.\mathrm{c}_{\text {HyA,titrálandó }}=0,1 \mathrm{mg} / \mathrm{mL}, \mathrm{c}_{\text {Chit,titráló }}=2 \mathrm{mg} / \mathrm{mL}\right)$ és $(\mathbf{B})$ a H-HyA áramlási potenciáljának változása $\mathrm{pH} \approx 4,5$ ecetsav-acetát pufferes közegben $(H-H y A: \mathrm{c}=0,045 \mathrm{mg} / \mathrm{mL}, M$-Chit: $\mathrm{c}=$ $0,091 \mathrm{mg} / \mathrm{mL}$ )

A reológiai és töltéstitrálási vizsgálatoknál meghatározott értékek jelentősen eltérnek az 1:1 mólaránytól, melyet a M-HyA/CTAB rendszer eredményeire alapozva várnánk. Ennek oka, hogy ezen a tartományon a H-HyA polimer láncon lévő karboxilcsoportok részben protonált/deprotonált állapotban vannak $\left(\mathrm{pK}_{\mathrm{a}}=2,90\right.$ [100]) (40.B. ábra), illetve a M-Chit -nál $\left(\mathrm{pK}_{\mathrm{a}}=6,41\right.$ [147]) a nem teljes deacetilezilezés miatt a pozitív töltéssel rendelkező aminocsoportok csak kb. 80 \% -a szabad. Az áramlási potenciál változását $\mathrm{pH}=$ 4,5 esetében is meghatároztuk, ahol a H-HyA és a M-Chit közel 100\% -ban rendre deprotonált és protonált formában vannak és már csak a M-Chit deacetilezési fokának mértékével kell számolni. A 40.B. ábrán bemutatott eredmények alapján az áttöltés 
$\mathrm{n}_{\text {Chit }} / \mathrm{n}_{\mathrm{HyA}} \sim$ 1,271 monomer mólarányoknál következik be (polimer tömegarányra nézve $\left.\mathrm{m}_{\text {Chit }} / \mathrm{m}_{\mathrm{HyA}}=0,537\right)$, mely jó egyezésben van azzal, hogy a pozitív töltéssel rendelkező aminocsoportok csak kb. $80 \%$-a szabad.

A HyA/Chit komplex hordozó rendszerek előállítása előtt, a makromolekulák közötti kölcsönhatások mértékének feltérképezése érdekében különböző $\mathrm{m}_{\mathrm{Chit}} / \mathrm{m}_{\mathrm{HyA}}$ tömegarányok mellett $1 \%$ ecetsavas közegben elkészített mintákat tisztítás és liofilizálás után FT-IR és termoanalitikai (TG, DTG, DSC) méréseit is elvégeztük. (Tisztításkor a mintákat $20 \mathrm{~mL}$-re felhígítottuk, 15 percig 12000 rpm fordulatszámon centrifugáltuk, majd a felülúszót eltávolítottuk. Ezt az eljárást háromszor megismételtük.)

A különböző poliszacharid tömegarányú H-HyA/M-Chit komplexek IR spektrumai csak kismértékben térnek el a kiindulási polimerek megfelelő spektrumaitól, ezenkívül újabb csúcsok megjelenése nem azonosítható (42. ábra).

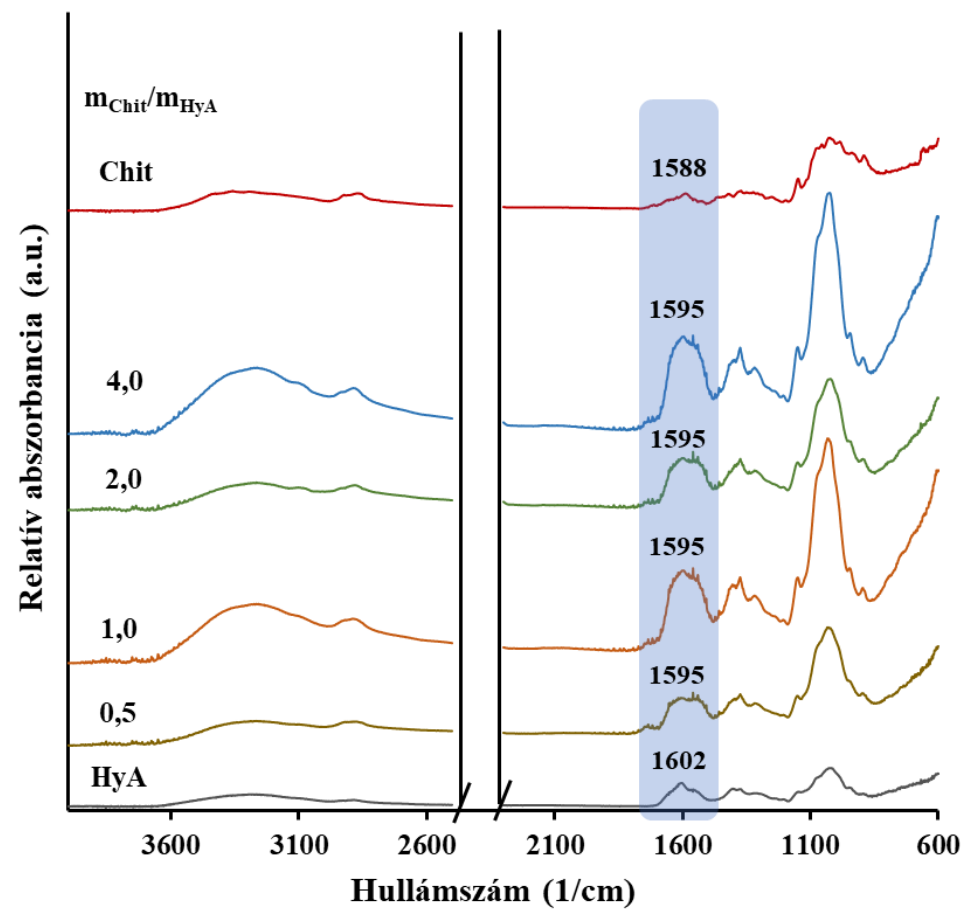

42. ábra: A M-Chit, a H-HyA és a különböző tömegarányok mellett készített és liofilizált H-HyA/M-Chit komplexek FT-IR spektrumainak megfelelő részletei ( $\mathrm{V}_{\text {össz }}=10 \mathrm{~mL}$, $\left.\mathrm{c}_{\text {HyA,törzs }}=2 \mathrm{mg} / \mathrm{mL}, \mathrm{c}_{\text {Chit,törzs }}=2 \mathrm{mg} / \mathrm{mL}, \mathrm{c}_{\text {ecetsav }}=1(\mathrm{v} / \mathrm{v}) \%\right)$

Ez arra utal, hogy a polimerek között erösebb kölcsönhatás nem alakul ki. A legnagyobb változás a H-HyA karboxilátcsoportjához tartozó C-O aszimmetrikus nyújtórezgés (1610-1540 $\mathrm{cm}^{-1}$ ) és M-Chit aminocsoportjához tartozó N-H deformációs rezgéseknél $\left(\sim 1585 \mathrm{~cm}^{-1}\right)$ látható [133,148]. A kiindulási polimerek spektrumát nézve a kezdeti H-HyA karboxilát - $\left(1602 \mathrm{~cm}^{-1}\right)$ és a M-Chit aminocsoportok $\left(1588 \mathrm{~cm}^{-1}\right)$ a 
komplexeknél egy $1595 \mathrm{~cm}^{-1}$-nél megjelenő közös széles csúcsban összeolvadnak. Ez másodrendü kölcsönhatások kialakulására utalhat. A komplexek elnyelési sávjainak relatív abszorbancia arányai a kezdeti polimer tömegarányokkal nem változnak, így a rendszerben kialakuló H-HyA/M-Chit minták összetétele megegyezik. Ez azt is bizonyítja, hogy a feleslegben lévő Chit a már kialakuló polielektrolit komplexekhez nem kötődik.

A TG mérések során megfigyelhető tömegváltozások a kiindulási tiszta polimereknél és a H-HyA/M-Chit komplexeknél eltérnek, de a $m_{\text {Chit }} / m_{H y A}$ tömegarány függvényében a görbék szinte azonos lefutást mutatnak (43.A. ábra). A tömeg kezdeti csökkenését a nagyrészt fizikailag megkötött víz eltávozása okozza. A poliszacharid komplexeknél $180{ }^{\circ} \mathrm{C}$ -ig a megkötött víz mennyisége $9,7 \%\left(\mathrm{~m}_{\mathrm{HyA}}: \mathrm{m}_{\text {Chit }}=1: 0,5\right), 11,6 \%\left(\mathrm{~m}_{\mathrm{HyA}}: \mathrm{m}_{\text {Chit }}=1: 1\right), 14,0$ $\%\left(m_{\text {HyA }}: m_{\text {Chit }}=1: 2\right)$ és $15,5 \%\left(m_{\text {HyA }}: m_{\text {Chit }}=1: 4\right)$ folyamatosan nő a M-Chit mennyiségével. A vízvesztés után a polimerek degradációs folyamatai játszódnak le. A hőmérsékletek pontos meghatározásához a DTG görbéket használtunk.
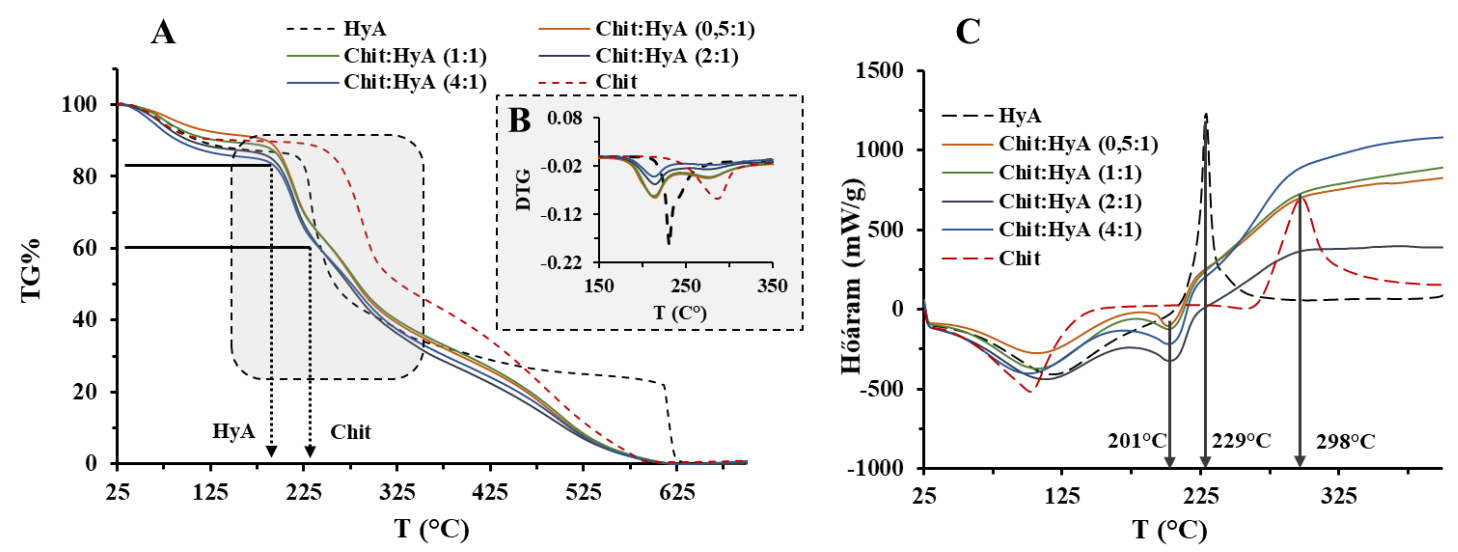

43. ábra: A HyA, Chit és a különböző tömegarányok mellett elkészített és liofilizált HyAChit komplexek (A) TG, (B) DTG és (C) DSC görbéi ( $V_{\text {össz }}=10 \mathrm{~mL}$, $\mathrm{c}_{\mathrm{HyA} \text {,törzs }}=2 \mathrm{mg} / \mathrm{mL}$, $\left.\mathrm{c}_{\text {Chit,törzs }}=2 \mathrm{mg} / \mathrm{mL}, \mathrm{c}_{\text {ecetsav }}=1(\mathrm{v} / \mathrm{v}) \%\right)$

A 43.B. ábrán a mintákban lévő H-HyA és M-Chit jelenléte jól azonosítható. A H-HyA és M-Chit makromolekulákhoz köthető degradációk ( $\mathrm{T}_{\mathrm{d}, \mathrm{HyA}}=180{ }^{\circ} \mathrm{C}$ és $\left.\mathrm{T}_{\mathrm{d}, \mathrm{Chit}}=245{ }^{\circ} \mathrm{C}\right) \mathrm{a}$ kiindulási polimerekéhez képest nagymértékü eltolódást mutatnak $\left(\mathrm{T}_{\mathrm{d}, \mathrm{HyA}}=205^{\circ} \mathrm{C}, \mathrm{T}_{\mathrm{d}, \mathrm{Chit}}=\right.$ $221^{\circ} \mathrm{C}$ ), melyet a M-Chit-H-HyA között kialakuló kölcsönhatások okozhatják. Az arányok módosításával a hőmérsékletek nem változnak. A TG görbékből meghatároztuk a kizárólag H-HyA poliszacharidhoz tartozó tömegváltozás százalékos arányát $\left(180^{\circ} \mathrm{C}-245^{\circ} \mathrm{C}\right.$ között), ahol minden esetben $26 \%$-ot kaptunk. A víz tömegének kezdeti minta tömegéből történő kivonásával $\left(\mathrm{m}_{\text {minta }}-\mathrm{m}_{\mathrm{viz}}\right)$ a komplexben lévő tisztán H-HyA -hoz $\left(180^{\circ} \mathrm{C}\right.$-tól $245^{\circ} \mathrm{C}$-ig) 
és H-HyA/M-Chit keverékhez $\left(245^{\circ} \mathrm{C}\right.$-tól $650^{\circ} \mathrm{C}$-ig) tartozó százalékos tömegváltozásokat is összehasonlíthatjuk. Az eredmények szerint a $245^{\circ} \mathrm{C}$-ig a tömeg $30 \%$-kal és $245^{\circ} \mathrm{C}$-tól $650{ }^{\circ} \mathrm{C}$-ig $70 \%$-kal csökken függetlenül a m $\mathrm{m}_{\mathrm{Chi}} / \mathrm{m}_{\mathrm{HyA}}$ tömegaránytól. Ez egyértelmü bizonyítéka lehet annak, hogy a komplexek összetétele megegyezik.

A minták DSC méréseinél az első endoterm csúcs a víz elpárolgásához rendelhető, amit a poliszacharidok degradációja követ (43.C. ábra). A görbék lefutása megegyezik, így a TG és FT-IR módszerekhez hasonlóan a DSC is igazolja a komplexek azonos összetételét. Az alkalmazott tiszta makromolekulákkal ellentétben a komplex minták degradációjánál egy endoterm csúcs jelenik meg $200{ }^{\circ} \mathrm{C}$ hőmérsékleten. Ez a komplexek és az elektrosztatikus kölcsönhatások kialakulását egyértelműen bizonyítja. A $298^{\circ} \mathrm{C}$-nál megfigyelhető exoterm csúcs hiánya arra utal, hogy az előállításkor beállított töltésarány szerinti M-Chit felesleget a minták nem tartalmaznak, mely a tisztítási lépés sikereségét igazolja. Az eredmények alapján a két makromolekula fizikai keveréknek jelenléte kizárható és valóban hatóanyag hordozóként alkalmazható PEC képződik.

\subsubsection{HyA-Chit hatóanyag hordozó rendszerek elöállitása és jellemzése}

A hialuronsav-kitozán között kialakuló elektrosztatikus kölcsönhatás tanulmányozását követően különböző technikákat alkalmazva három különböző szerkezetü, hatóanyag hordozóként is alkalmazható poliszacharid alapú nanorészecskét állítottunk elő, melyek sematikus ábrája a 44. ábrán látható. Első esetben egyéb komponens hozzáadása nélkül a tisztán elektrosztatikusan kompenzált Chit/HyA (továbbiakban Chit/HyA I. jelölésü) komplexeket hoztunk létre a poliszacharid oldatok fizikai keverésével, mely rendszerek szerkezeti karakterizálásával az 5.4.1 fejezetben foglalkoztunk részletesen. Ezek után tripolifoszfáttal (TPP) ionosan keresztkötött Chit-TPP/HyA (továbbiakban Chit/HyA II.) és mag-héj szerkezetü Chit-TPP $\mathrm{mag} / \mathrm{HyA}_{\text {héj }}$ (továbbiakban Chit/HyA III.) részecskéket is előállítottunk különböző Chit:HyA tömegarányokon. Chit/HyA II. esetén a Chit oldatot HyA/TPP oldatkeverékbe csepegtettük folyamatos kevertetés mellett, míg a Chit/HyA III. jelölésű rendszernél először a keresztkötött Chit magot (Chit/TPP ${ }_{\text {mag }}$ ) alakítottuk ki, majd azt a HyA héj kialakítása érdekében a megfelelő koncentrációjú H-HyA oldatba adagoltuk. A nagy molekulatömegü HyA (H-HyA: $\left.\mathrm{M}_{\mathrm{w}}=1500-1800 \mathrm{kDa}\right)$ alkalmazása mellett Chit/HyA I. -nél közepes (190-310 kDa), míg Chit/HyA II.- és III.-nál nagy (310-375 kDa) molekulatömegü Chit használtunk. 


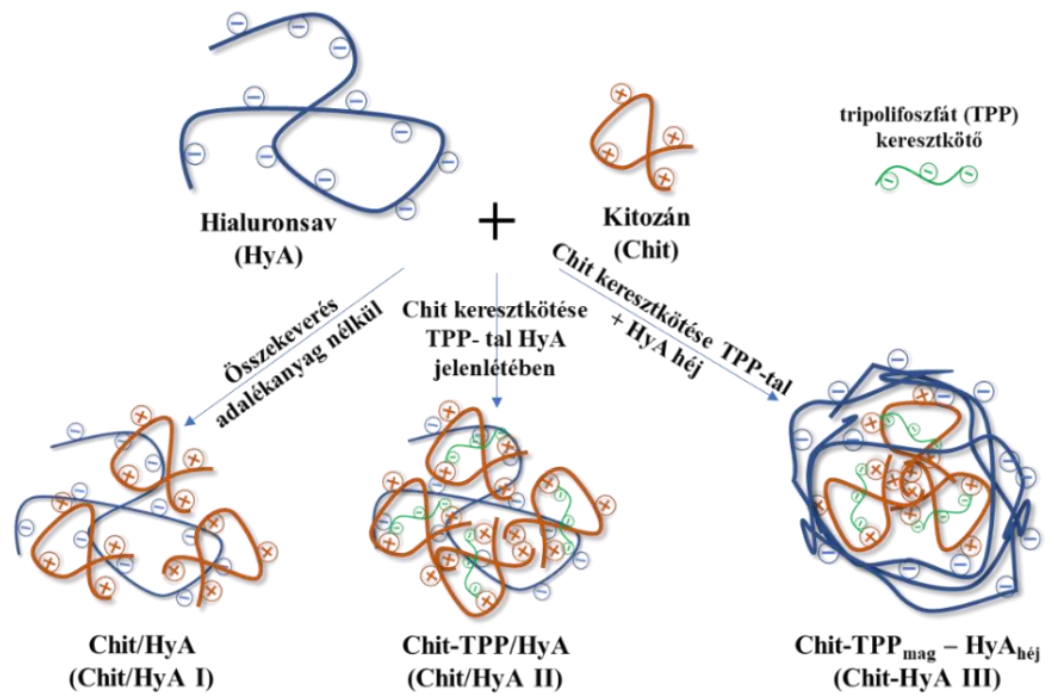

44. ábra: A három különböző típusú Chit/HyA hordozó előállításának és a lehetségesen képződő részecskék szerkezetének sematikus ábrázolása

Annak érdekében, hogy a H-HyA deprotonált formában és a Chit még protonált állapotban legyen, a Chit-nál pH= 4,4-4,7 ecetsav-acetát pufferes, míg a HyA -nál Milli-Q vizes közeget alkalmaztunk. A hidrodinamikai átmérő és a méreteloszlásának meghatározása érdekében DLS méréseket végeztünk.

A Chit/HyA I. esetén megfigyeltek szerint elektrosztatikus kompenzálással alacsony hidrodinamikai átmérővel rendelkező részecskék képződése figyelhető meg (45.A. ábra). $\mathrm{m}_{\text {Chit }} / \mathrm{m}_{\mathrm{HyA}}=80-40$ tömegarány tartományban, ahol a M-Chit koncentrációja a H-HyA- hoz képest nagyobb, részecskék kialakulása nem volt detektálható. Az arányokat tovább csökkentve $\left(\mathrm{m}_{\mathrm{Chit}} / \mathrm{m}_{\mathrm{HyA}}=40-20\right)$ a rendszerben kis hidrodinamikai átmérővel rendelkező részecskék jelennek meg $\left(\mathrm{d}_{\mathrm{DLS}} \approx 168 \mathrm{~nm}\left(\mathrm{~m}_{\text {Chit }} / \mathrm{m}_{\mathrm{HyA}}=40\right), \mathrm{d}_{\mathrm{DLS}} \approx 195 \mathrm{~nm}\left(\mathrm{~m}_{\mathrm{Chit}} / \mathrm{m}_{\mathrm{HyA}}=20\right)\right)$. A $\mathrm{m}_{\text {Chit }} / \mathrm{m}_{\mathrm{HyA}}=20-1$ közötti tömegarányoknál a töltéssemlegesítési ponthoz $\left(\mathrm{m}_{\mathrm{Chi}} / \mathrm{m}_{\mathrm{HyA}}=\right.$ 0,537) közeledve a részecskeméret ( $\mathrm{d}_{\mathrm{DLS}} \approx 195 \mathrm{~nm}$-ről $864 \mathrm{~nm}$-re) és a rendszer polidiszperzitása növekvő tendenciát mutat. Ennek legfőbb oka, hogy a neutralizálási pontnál a részecskék töltése semlegesé válik, amit aggregációs folyamatok követnek. Az áttöltési pont után H-HyA feleslegnél is megvizsgáltuk a lehetségesen képződő részecskék méretét $\left(\mathrm{m}_{\mathrm{Chit}} / \mathrm{m}_{\mathrm{HyA}}=0,500-0,125\right)$, ahol ismételten alacsony $\left(\mathrm{d}_{\mathrm{DLS}}=103-199 \mathrm{~nm}\right)$ értékeket kaptunk. Ez arra utal, hogy az orvosbiológiai felhasználásra alkalmas nanorészecskék képződése csak jelentős M-Chit vagy H-HyA többlet esetén kedvezményezett. 

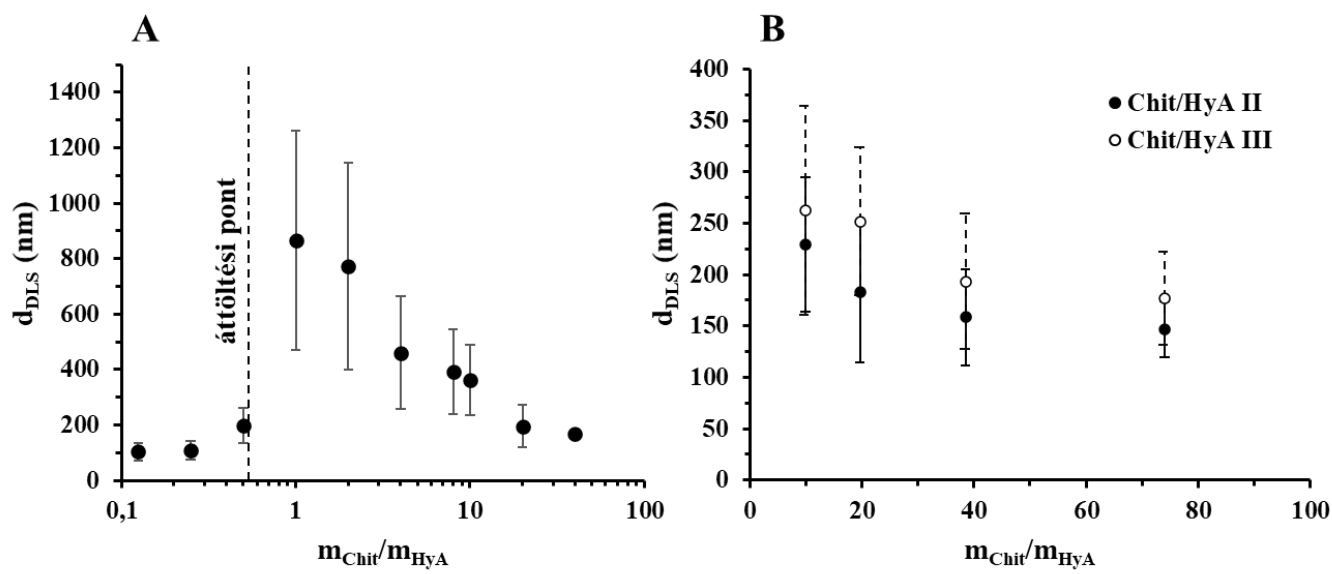

45. ábra: (A) Chit/HyA I. $\left(m_{C h i t} / m_{H y A}=0,125-1,00: \mathrm{c}_{\mathrm{Chit}}=0,091 \mathrm{mg} / \mathrm{mL}, \mathrm{V}_{\text {Chit }}=0,5-4,0\right.$ $\mathrm{mL}, \mathrm{c}_{\mathrm{HyA}}=0,042 \mathrm{mg} / \mathrm{mL}, \mathrm{V}_{\mathrm{HyA}}=8,72 \mathrm{~mL} ; m_{C h i t} / m_{H y A}=4-80: \mathrm{c}_{\mathrm{Chit}}=0,364 \mathrm{mg} / \mathrm{mL}, \mathrm{V}_{\text {Chit }}=$ 4,0 mL, $\mathrm{c}_{\mathrm{HyA}}=0,134-0,0067 \mathrm{mg} / \mathrm{mL}, \mathrm{V}_{\mathrm{HyA}}=2,72 \mathrm{~mL}$; HyA: Milli-Q vizes közeg, Chit: $\mathrm{pH}$ $\approx 4,5)$, illetve (B) Chit/HyA II. és III. részecskék hidrodinamikai átmérőjének változása a Chit:HyA tömegarány függvényében ( $\mathrm{c}_{\mathrm{Chit}}=0,30 \mathrm{mg} / \mathrm{mL}, \mathrm{c}_{\mathrm{TP}}=0,15 \mathrm{mg} / \mathrm{mL}, \mathrm{c}_{\mathrm{HyA}}=3,9-31$ $\mu \mathrm{g} / \mathrm{mL} ;$ Chit $/$ HyA II: $\mathrm{V}_{\text {össz }}=4,73 \mathrm{~mL}$, Chit $/ H y A$ III: $\mathrm{V}_{\text {össz }}=4 \mathrm{~mL}$ )

S. Huang és munkatársai által előállított elektrosztatikusan kompenzált Chit/HyA nanorészecskéknél a 100 nm körüli átméröt csak kis molekulatömegü poliszacharidokkal (10 kDa -os HyA és 100 kDa-os Chit) tudták kivitelezni korábban [149]. A kizárólag elektrosztatikus kompenzáláson alapuló eljáráshoz képest, ahol főként laza kolloid szerkezet alakul ki, a Chit/HyA II. és III. tartalmú minták esetében a TPP keresztkötő ágensnek köszönhetően sokkal monodiszperzebb és könnyebben méretszabályozható részecskék képződnek (45.B. ábra). $\mathrm{m}_{\mathrm{Chit}} / \mathrm{m}_{\mathrm{HyA}}=80-10$ tömegarányok között a három módszert összehasonlítva kitünik, hogy a legkisebb hidrodinamikai átmérővel a Chit/HyA II. rendelkezik. A Chit/HyA III. esetében a kezdeti Chit-TPP mag méretéhez $\left(\mathrm{d}_{\mathrm{DLS}}=147 \pm 45\right.$ $\mathrm{nm}$ ) képest az átmérők nagyobbak, ami alapján a részecskék H-HyA héjjal történő bevonása sikeresnek bizonyult. Ennek a szerkezetnek a kialakulása okozza a Chit/HyA III. típusú részecskének a Chit/HyA II.- vel szembeni nagy átlagos részecskeméretét is. A Chit/HyA I. -hez hasonlóan a növekvő H-Chit aránynak köszönhetően a részecskeméret folyamatosan csökken (Chit/HyA II: dDLS= 230 -tól 146 nm-ig; Chit/HyA III: d dLs= 262 nm -töl 177 nm ig). Fontos megjegyezni, hogy a mag-héj struktúra elérésekor az előre kialakított H-Chit magon kevesebb szabad kötőhely érhető el, mint a Chit/HyA I. és II. -nél. Ennek következtében az aggregációs folyamatok már $10 \mathrm{w} / \mathrm{w} \%$-os H-HyA esetén elindulnak. 


\section{6. Összefoglaló}

A (bio)polimer alapú nanoszerkezetü hatóanyag hordozó rendszerek, széleskörü alkalmazhatóságuknak köszönhetően, az elmúlt néhány évtizedben egyre nagyobb szerepet töltenek be gyógyszerészeti és nanomedicina kutatási területeken is. A hordozók kialakítását szabályzó kísérleti paraméterek és előállítási technikák variálásával minden egyes gyógyszerszármazékra optimalizált rendszert állíthatunk elő, amelynek eredményeként mind a hatóanyag felszabadulás mind a hatékonyság kontrollálhatóvá válik.

Néhány éve kutatócsoportunkban kitüntetett szereppel bír a főként szérum fehérje alapú hatóanyag hordozó kolloid részecskék előállítása, ahol a fő cél neuroaktív vegyületek vér-agy gáton való transzportjának megvalósítása. A kutatásokat folytatva 2017. őszén kezdtem el munkámat egy újonnan elnyert GINOP-2.3.2 pályázat keretein belül. Kiemelt feladatom volt elsősorban polimer és poliszacharid alapú, új típusú hatóanyag hordozó rendszerek tervezése és optimalizálása reprodukálható szintézisek kidolgozásán keresztül. Sikeresen kiviteleztük makromolekulás kolloidokból (PLA, PLGA, HyA, Chit) felépülő, nanoszerkezetű hordozó rendszerek kialakítását, ahol tanulmányoztuk az alkalmazott hordozók tulajdonságainak (pl. hidrofilitás, szerkezet, felületi töltés) és a modellként alkalmazott eltérő hidrofilitású, szerkezetű és töltésű kismolekulák kapszulázási hatékonyságára gyakorolt hatását. Meghatároztuk, hogy a képződő részecskék méretét, szerkezetét, morfológiáját milyen kísérleti tényezők befolyásolják. Továbbá, ahol lehetőség adódott, a hatóanyag felszabadulás kinetikáját is tanulmányoztuk.

Doktori munkám első lépéseként hatóanyag hordozóként alkalmazható PLA és különböző laktid / glikolid arányú PLGA kopolimereket állítottam elő gyürüfelnyitásos polimerizációs eljárással, melynek sikerességét DSC és FT-IR spektroszkópiás mérésekkel igazoltuk. A fényszórási kísérletekkel és a precipitációs titrálási görbékkel alátámasztottuk, miszerint az általunk előállított PLA/ PLGA polimerek alacsony molekulatömeggel és szük méreteloszlással rendelkeznek. A peremszög mérések által jellemzett nedvesedési tulajdonságok a kereskedelmi forgalomban kapható ugyanezen polimerek peremszög értékeivel jó egyezést mutattak. Mindezek mellett igazoltuk, hogy a szintetizált kopolimerek hidrofilitása szisztematikusan nő a glikolid mennyiségének növekedésével (PLA: 74,55 \pm 0,82 ${ }^{\circ}$, PLGA75: 70,50 $\pm 0,25^{\circ}$, PLGA65 68,18 $\pm 0,61^{\circ}$ ).

A szintetizált PLA/PLGA makromolekulákból nanoprecipitációs módszerrel kolloid mérettartományú részecskéket állítottunk elő. Megállapítottuk, hogy a részecskék hidrodinamikai átmérője, szerkezete és stabilitása az alkalmazott oldószerek (1,4-dioxán, 
aceton) anyagi minőségével (forráspont, sürüség különbség) és felületaktív anyagként alkalmazott molekulák (PLUR, PVA, CTAB) kémiai szerkezetével (molekulatömeg, töltés) kontrollálható. DLS mérések és a rögzített TEM felvételek által igazoltuk, hogy az 1,4dioxánhoz képest kisebb sűrüségü és forráspontú aceton, mint szerves fázis, alkalmazásával 10-70 nm -rel kisebb részecskék állíthatóak elő. A stabilizátorként alkalmazott molekulák tanulmányozásánál megállapítottuk, hogy a legnagyobb hidrodinamikai átmérőt és $\zeta$ potenciál értéket a pozitív töltésű funkciós csoporttal rendelkező CTAB esetén (pl. 261

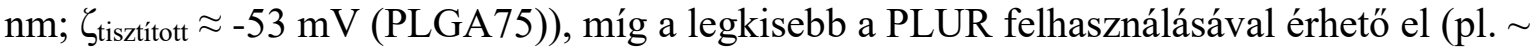
$180 \mathrm{~nm}, \zeta_{\text {tisztitott }} \approx-88 \mathrm{mV}$ (PLGA75). Ezen eredmények alapján kijelenthető, hogy a stabilizátor megfelelő kiválasztásával a gyógyszerhordozó részecskék mérete tovább csökkenthető. A PLA/PLGA alapú makromolekulás kolloidok hatóanyag kapszulázási képességének tanulmányozásakor megállapítottuk, hogy eltérő hidrofilitási tulajdonsággal rendelkező vegyületek (TPGS > KP > TP) esetében a molekulák hidrofilitásának csökkenésével a mag-héj szerkezetü hatóanyag hordozó rendszerek képződése is lehetséges, mely a legkevésbé vízoldékony TP esetén egyértelmủen igazolható.

A mag-héj struktúrával rendelkező TP-tartalmú PLA részecskéknél megállapítottuk, hogy a hordozó, a hatóanyag és a stabilizátor koncentráció arányai a szerkezet kialakulását és a kapszulázási hatékonyságot nagymértékben befolyásolja. A TEM felvételekkel igazoltuk, hogy az egyes komponens koncentrációk csökkenésével a mag-héj struktúra kialakulása kedvezőtlenné válik. A részecskeméret és a szerkezet szerint optimalizált koncentráció paraméterek mellett ( $\mathrm{c}_{\mathrm{PLA} / \mathrm{PLGA}}=10 \mathrm{mg} / \mathrm{mL}$ és $\mathrm{c}_{\mathrm{TP}}=2,5 \mathrm{mg} / \mathrm{mL}(1 \mathrm{~mL}$ aceton fázis), $C_{P L U R}=0,1 \mathrm{mg} / \mathrm{mL}$ (10 mL vizes fázis)), a laktid/glikolid aránytól függően átlagosan d= 200-225 nm nagyságú hidrodinamikai átmérö érhető el. A PLA/PLGA makromolekulák hidrofil jellegének növelésével a TP kapszulázási hatékonysága tovább növelhető. A kolloid részecskék hatóanyag tartalmát vizsgálva megállapítottuk, hogy a legnagyobb kapszulázási hatékonyság a PLGA65 esetében figyelhető meg (PLGA65: 88 \%, PLGA75: 75\%, PLA: 69 $\%)$.

PLGA alapú hordozó rendszereknél megvizsgáltuk, hogy a mag-héj struktúra előállítható-e egy mikroreaktorral ( $\mu$-mixer cella) ellátott folyamatos áramú berendezéssel. Igazoltuk, hogy megfelelő áramlási sebességek mellett TP nélküli és TP-tartalmú PLGA50 kolloid mérettartományú részecskék keletkeznek. A szintézis paramétereket optimalizálva megállapítottuk, hogy a nanoprecipitációs módszerhez képest $(\sim 160 \mathrm{~nm})$ ezen eljárással kisebb hidrodinamikai átmérővel rendelkező mag-héj nanoszerkezetü részecskék állíthatóak elő ( $135 \mathrm{~nm})$. Az eredmények rámutattak arra, hogy a két módszernél a kapszulázási 
hatékonyság vonatkozásban hasonló értékek érhetőek el. ( 67,1 \% (nanoprecipitációs módszer), 71,5\% (áramlásos módszer)).

Munkánk során megvizsgáltuk a TP-PLA/PLGA és TP-PLUR között kialakuló kölcsönhatásokat is. A különböző TP-tartalmú PLA részecskéken végzett FT-IR mérések alapján a PLA-TP között nem alakul ki számottevő kölcsönhatás, így a hatóanyag kioldódását egyéb szerkezeti hatások nem befolyásolják. Turbidimetriás módszerrel igazoltuk, hogy a PLUR jelenlétében a TP oldhatósága megnövelhető, melyet a hőmérséklet emelése és a PBS közeg alkalmazása tovább növel.

In vitro körülmények között meghatároztuk a TP-tartalmú PLA/PLGA rendszerek kioldódási görbéit. Az eredmények azt bizonyították, hogy a polimerek hidrofil jellegének és a kapszulázott hatóanyag mennyiségének növelésével hatóanyag visszatartás is nő (PLA: 35,0 \%; PLGA75: 28,3 \%, PLGA65: 19,8 \%, PLGA50 nanoprecipitáció: $8 \%$, PLGA50áramlásos technika: $12 \%$ ). A kioldódási adatokra nemlineáris regresszióval illesztett kinetikai modellek közül, a determinációs együtthatót figyelembe véve, a legjobb illesztést a Weibull és a Korsmeyer-Peppas egyenletek adják $\left(\mathrm{R}^{2} \approx 0,99\right)$. A sikeresen definiált kinetikai paraméterek igazolták a kioldódási folyamatok föként diffúzió kontrollált jellegét.

A PLA/PLGA alapú rendszerek tanulmányozását követően a hidrofil tulajdonságú HyA térhálósításával és neutralizálásával (CTAB, Chit) állítottunk elő hatóanyag hordozó kolloid részecskéket. A részecskék előállítása mellett a HyA származékok szerkezeti változásait, összetételét és a kialakuló kölcsönhatásokat is jellemeztük. FT-IR és termoanalitikai mérésekkel igazoltuk, hogy 200-500 kDa átlagos molekulatömegü M-HyA diaminnal történő részleges (50-75\% cl-M-HyA) és teljes (100\% cl-M-HyA) térhálósítása sikeresen megtörtént. Dinamikus fényszórás mérésekkel és TEM felvételekkel igazoltuk, hogy a rendszerekben tisztán hialuronsav alapú kolloid részecskék képződnek, amelyek hidrodinamikai átmérője a keresztkötés mértékének növelésével d 45 nm -ről (50 \% cl-MHyA) d $110 \mathrm{~nm}$-re (100 \% cl-M-HyA) folyamatosan nő. A legnagyobb kolloid stabilitást a $100 \%$-ban keresztkötött származéknál állapítottuk meg ( $\sim-23,6 \mathrm{mV})$.

Kationos felületaktív anyag (CTAB) alkalmazásával is eredményesen állítottunk elő hialuronsav/tenzid komplex nanorészecskéket. Konduktometriás, izoterm titrációs

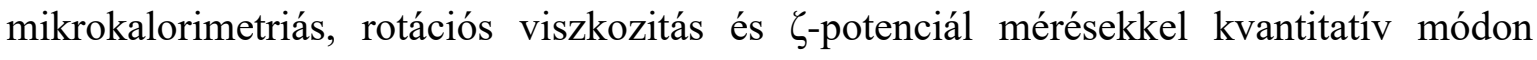
jellemeztük a makromolekula és a felületaktív anyag kölcsönhatását. A vizsgálatokkal reproduktívan igazoltuk, hogy a M-HyA monomer egységenkénti egy negatív töltése közel egy CTAB molekula révén kompenzálható. A teljes töltéskompenzálás eléréséig kis méretü kolloid részecskék képződése a preferált $\left(\mathrm{d} \sim 50 \mathrm{~nm}\left(\mathrm{~m}_{\mathrm{CTAB}} / \mathrm{m}_{\mathrm{HyA}}=0,75\right)\right)$, míg a 
neutralizálás közelében a részecskék nagymértékü aggregációja figyelhető meg, mely már kedvezőtlen gyógyszerhordozó rendszerként történő felhasználáshoz.

A M-HyA és a módosított M-HyA viszkozitási (és ezzel szerkezeti) tulajdonságának meghatározásához különböző reológiai méréseket végeztünk. A vizsgálatok által igazoltuk, hogy a polimer oldatok, valamint a M-HyA hidrogélek a koncentráció növekedésével $(0,05$ $\mathrm{mg} / \mathrm{mL}$-től $100 \mathrm{mg} / \mathrm{mL}-\mathrm{ig}$ ) Newtoni-, pszeudoplasztikus, majd viszkoelsztikus viselkedést mutatnak. A hidrogélek esetében elvégzett oszcillációs mérések alapján megerősítettük, hogy a koncentráció növekedésével, $100 \mathrm{mg} / \mathrm{mL}$ M-HyA koncentrációt elérve, a gélek elasztikus viselkedése a domináns a viszkózus sajátsággal szemben. Megállapítottuk továbbá, hogy a keresztkötött hidrogéleknél a keresztkötés mértékének növekedésével, a koherens gélszerkezet felbomlása miatt, a viszkózus-, míg a kationos tenziddel neutralizált asszociációs kolloidok esetében a tenzid koncentráció növelésével az elasztikus sajátság válik meghatározóvá.

A keresztkötött és a M-HyA/CTAB szerkezeti vizsgálatai után az előállított nanorészecskéket eredményesen alkalmaztuk KP molekulák kapszulázására. A kioldódási görbék alapján igazoltuk, hogy mérhetően nagy hatóanyag visszatartás érhető el a MHyA/CTAB nanorészecskék alkalmazása esetén. Az adatokra legjobban illeszkedő Korsmeyer-Peppas és a Weibull kinetikai modellek rámutattak, hogy a cl-M-HyA mintáknál minden esetben a főként diffúzió kontrollált hatóanyag kioldódás a domináns, míg a MHyA/CTAB rendszernél a CTAB mennyiségének növelésével a diffúzió kontrol mellett az eróziós folyamatok hatása egyre erősebbé válik.

Kvantitatív módon tanulmányoztuk a kitozán és a hialuronsav makromolekulák kölcsönhatását. Az áramlási potenciál és látszólagos viszkozitási görbék alapján a monomeregységenként egy pozitív (Chit) és egy negatív töltéssel (H-HyA) rendelkező makromolekulák közötti elektrosztatikus kölcsönhatás mértékét, ezáltal a várt 1:1 monomer mólarány szerinti teljes töltéskompenzálást, a közeg pH-ja és a Chit deacetilezési foka erősen befolyásolja. A FT-IR és termoanalitikai (TG, DTG, DSC) vizsgálatokkal, megállapítottuk, hogy a M-Chit-H-HyA komplexek összetétele a poliszacharidok tömegarányával nem változik. Különböző technikákkal sikeresen állítottunk elő eltérő szerkezeti felépítésü elektrosztatikusan kompenzált Chit/HyA, tripolifoszfáttal (TPP) keresztkötött Chit-

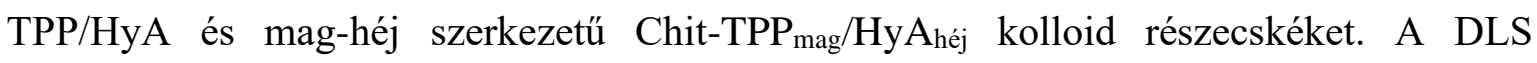
eredmények alapján megállapítottuk, hogy a kisméretű részecskék képződése $(d=100-300$ $\mathrm{nm})$, a fenn felsorolt részecskék típusától függetlenül, jelentősebb Chit $\left(\mathrm{m}_{\mathrm{Chit}} / \mathrm{m}_{\mathrm{HyA}}=20-80\right)$ vagy HyA $\left(\mathrm{m}_{\mathrm{Chit}} / \mathrm{m}_{\mathrm{HyA}}=0,125-0,500\right)$ makromolekula túlsúly esetén a kedvezményezett. 


\section{Summary}

Due to the wide applicability of the (bio) polymer-based nanostructured drug delivery systems, in the last few decades they have an increasing role in the pharmaceutical and nanomedicine research fields as well. By varying the experimental parameters and preparation techniques that control the formation of these carriers, we can produce an optimized system for each drug derivative, as a result of thereby, both the release and the efficacy can be controlled.

In recent years, the preparation of mostly protein-based drug carrier colloid particles has a special role in our research group, where the main goal is the successful penetration of neuroactive molecules across the blood-brain barrier. Continuing this research, I started my work in the autumn of 2017, within the framework of a newly won GINOP-2.3.2 tender. My main task was to design and optimize new type of mainly polymer- and polysaccharidebased drug delivery systems via development of reproducible syntheses. We successfully developed macromolecular (PLA, PLGA, HyA, Chit) colloids-based, nanostructured carrier systems, where we studied the properties of these carrier systems (such as hydrophilicity, structure and surface charge) on the encapsulation efficiency of small molecules having different hydrophilicities, structures and charges. We determined that, what experimental factors influence the size, structure, and morphology of the formed particles. As it was possible, we studied the kinetics of drug release as well.

As the first step of my doctoral work, I successfully prepared PLA polymer and PLGA copolymers with different lactide / glycolide ratios by ring-opening polymerization process, which can be used as drug carriers confirmed by DSC and FT-IR spectroscopic measurements. Based on the light scattering experiments and the precipitation titration curves we confirmed that the synthesized PLA / PLGA polymers show a low molecular weight and narrow distribution. The wetting properties, which characterized by contact angle measurements, were in good agreement with the contact angle values of the same commercially available polymers. Furthermore, we confirmed that the hydrophilicity of the copolymers is systematically increased with increasing glycolide content (PLA: $74.55 \pm$ $0.82^{\circ}$, PLGA75: $70.50 \pm 0.25^{\circ}$, PLGA65 $68.18 \pm 0.61^{\circ}$ ).

In the next step, we prepared colloidal-sized particles from our synthesized PLA/PLGA macromolecules by nanoprecipitation method. Based on the experiments, the hydrodynamic diameter, structure and stability of the particles can be controlled by the material quality (boiling point, difference between the densities) of the solvents $(1,4-$ 
dioxane, acetone) and the chemical structure (molecular weight, charge) of the stabilizer molecules (PLUR, PVA, CTAB) as well. The DLS measurements and the recorded TEM images confirmed that the application of the acetone as organic phase, with lower density and boiling point than 1,4-dioxane, results in 10-70 nm smaller particles. For studying of the stabilizer molecules, we determined that the largest hydrodynamic diameter and $\zeta$-potential values were obtained for positively charged CTAB (e.g. $\sim 261 \mathrm{~nm}, \zeta_{\text {washed }} \approx-53 \mathrm{mV}$ (PLGA75)), while the smallest was achieved using PLUR (e.g., $\sim 180 \mathrm{~nm}, \zeta_{\text {washed }} \approx-88 \mathrm{mV}$ (PLGA75)). Based on these results, it can be stated that the size of the drug carrier particles can be further reduced with the appropriate selection of the stabilizer. For the determination of the encapsulation capability of the PLA/PLGA macromolecular colloids, we stated that, in case of the different hydrophilicity compounds (TPGS $>\mathrm{KP}>\mathrm{TP}$ ), the formation of the core-shell structured drug carrier systems is become possible by the decreasing of the hydrophilicity of the molecules. This structure was determined for the TP with the most hydrophobic property.

For the TP -loaded PLA nanoparticles having core-shell structure, we determined that the ratios of the carrier, the drug and the stabilizer concentration greatly influence the formation of the structure and the encapsulation efficiency. The TEM images showed that the formation of the core-shell structure is become unfavourable by decreasing of the component concentrations. Beside the particle size and structure- optimized concentration parameters $\left(\mathrm{CPLA}_{\mathrm{PLGA}}=10 \mathrm{mg} / \mathrm{mL}\right.$ és $\mathrm{c}_{\mathrm{TP}}=2.5 \mathrm{mg} / \mathrm{mL}(1 \mathrm{~mL}$ acetone phase $), \mathrm{c}_{\mathrm{PLUR}}=0.1$ $\mathrm{mg} / \mathrm{mL}$ (10 $\mathrm{mL}$ water phase), depending of the lactide/glycolide ratio, the average hydrodynamic diameter of $\mathrm{d}=200-225 \mathrm{~nm}$ can be achieved. As the hydrophilicity of the PLA/PLGA increases, the encapsulation efficiency of the TP can be increased. When examining the drug content of the colloidal particles, it was found that the highest encapsulation efficiency was observed for PLGA65 (PLGA65: $88 \%$, PLGA75: 75\%, PLA: $69 \%)$.

In case of PLGA-based delivery systems, we investigated whether this core-shell structure can be prepared with a microreactor ( $\mu$-mixer cell) -equipped continuous flow apparatus. We confirmed that the TP-free and TP-loaded PLGA50 colloidal particles are formed at appropriate flow rates. By optimizing of the synthesis parameters, we determined that core-shell nanostructured particles with smaller hydrodynamic diameter can be produced by this method $(\sim 135 \mathrm{~nm})$ compared to the nanoprecipitation method $(\sim 160 \mathrm{~nm})$. The results pointed out that, similar values for the encapsulation efficiency could be obtained for the two methods: ( $67.1 \%$ (nanoprecipitation), $~ 71.5 \%$ (flow method)). 
In our work, we examined the interactions between TP - PLA/PLGA and TP - PLUR too. Based on the FT-IR measurements of the different TP -loaded PLA, the measurable interaction between PLA-TP cannot be observed thus the dissolution of the drug cannot be influenced by structural alterations. By turbidimetry, we demonstrated that the solubility of TP can be increased in the presence of PLUR, which is further enhanced by the increase of the temperature and the application of PBS medium.

We determined the release curves of the TP-loaded PLA/PLGA systems in in vitro conditions. The results showed that the drug retention was increased with the increasing hydrophilicity of the polymers and the amount of the encapsulated drug (PLA: $35.0 \%$;

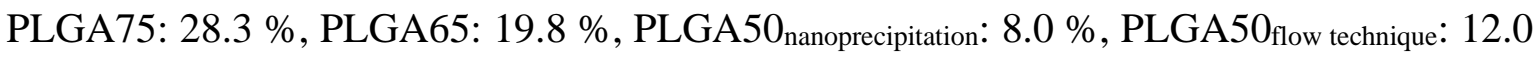
$\%)$. Among the kinetic models, which we fitted to the dissolution data by nonlinear regression, taking into the coefficient of determination account, the best fit is given by the Weibull and Korsmeyer-Peppas equations $\left(\mathrm{R}_{2} \approx 0.99\right)$. The successfully defined kinetic parameters confirm the mainly diffusion-controlled nature of the dissolution processes.

After studying PLA/PLGA -based systems, the drug carrier colloidal particles were prepared by cross-linking and neutralization (CTAB, Chit) of hydrophilic HyA. In addition to the preparation of the particles, we characterized the structural changes, the composition, and the evolving interaction of the HyA derivatives. FT-IR and thermoanalytical measurements confirmed that the partial (50-75\% cl-M-HyA) and complete (100\% cl-MHyA) cross-linking of the 200-500 kDa average molecular weight HyA with diamine was successful. Based on the dynamic light scattering measurements and the TEM images, pure hyaluronic acid -based colloidal particles were formed in the system, the hydrodynamic diameter continuously increases from $\mathrm{d} \sim 45 \mathrm{~nm}(50 \% \mathrm{cl}-\mathrm{M}-\mathrm{HyA})$ to $\mathrm{d} \sim 110 \mathrm{~nm}(100 \%$ cl-M-HyA) by increasing the degree of the cross-linking. The highest colloidal stability was found for the $100 \%$ cross-linked derivative $(\zeta \sim-23.6 \mathrm{mV})$.

Hyaluronic acid / surfactant complex nanoparticles were also successfully prepared by cationic surfactant (CTAB). Conductivity, isothermal titration microcalorimetry, rotational viscosity and $\zeta$-potential measurements quantitatively characterized the interaction between the macromolecule and the surfactant. By the measurements, we reproductively verified that one negative charge of M-HyA monomer unit can be compensated by nearly one CTAB molecule. Until the full charge compensation, the formation of the small colloidal particles is preferred $\left(\mathrm{d} \sim 50 \mathrm{~nm}\left(\mathrm{~m}_{\mathrm{CTAB}} / \mathrm{m}_{\mathrm{HyA}}=0,75\right)\right)$, while near the neutralization the large aggregation of the particles is observed, which is already unfavourable for using as drug delivery system. 
To determine the viscosity (and thus structural) property of the M-HyA and modified M-HyA, various rheological measurements were performed. The studies have confirmed, the polymer solutions and the hydrogels show Newtonian, pseudoplastic then viscoelastic behaviour with increasing of the concentration (from $0.05 \mathrm{mg} / \mathrm{mL}$ to $100 \mathrm{mg} / \mathrm{mL}$ ). Based on the oscillation measurements of the hydrogels, we showed that the increasing of the concentration, reaching of the $100 \mathrm{mg} / \mathrm{mL}$ M-HyA concentration, the elastic behaviour of the gels is dominant as against of the viscous property. It was further found, at the crosslinked hydrogels by the increasing of the cross-link degree, due to the disintegration of the coherent gel structure, the viscous-, while in case of the increasing surfactant concentration at the cationic surfactant (CTAB) neutralized association colloids, the elastic property is become dominant.

After the structural studies of the cross-linked M-HyA and the neutralized M-HyA/ $\mathrm{CTAB}$, the nanoparticles were successfully used to encapsulate KP molecules. We determined by the dissolution curves, that measurably high drug retention could be achieved with M-HyA / CTAB nanoparticles. The Korsmeyer-Peppas and Weibull kinetic models, which were shown best fitted to the data, were pointed out, the diffusion-controlled drug release is dominant for all cases of cl-M-HyA samples, while increasing of the CTAB amount in the M-HyA / CTAB system, on addition to diffusion control, the effect of erosion processes is become stronger.

The interaction of chitosan and hyaluronic acid macromolecules was studied quantitatively. We confirmed, the degree of the electrostatic interaction between the one positive (Chit) and one negative charge (H-HyA) monomer units-contained macromolecules, thereby the expected total charge compensation at the 1:1 monomer molar ratio, is strongly influenced by the $\mathrm{pH}$ of the medium and the degree of the deacetylation of Chit. By the FT-IR and the termoanalytical experiments, we determined that the composition of the Chit-HyA complexes does not change significantly with the weight ratio of the polysaccharides.

By different production protocols, we successfully prepared electrostatically compensated Chit / HyA, tripolyphosphate (TPP) cross-linked Chit-TPP / HyA, and coreshell structure Chit-TTP core $_{\text {/ HyA }}$ shell colloidal particles with different structural features. Based on the DLS results, we found that the formation of small particles $(\mathrm{d}=100-300 \mathrm{~nm})$, regardless of the type of the above listed particles, is beneficiary in case of the significant Chit $\left(\mathrm{m}_{\mathrm{Chit}} / \mathrm{m}_{\mathrm{HyA}}=20-80\right)$ or ${ }_{\mathrm{HyA}}\left(\mathrm{m}_{\mathrm{Chit}} / \mathrm{m}_{\mathrm{HyA}}=0.125-0.500\right)$ macromolecule predominance. 


\section{Irodalomjegyzék}

1. Mishra, B.; Patel, B.B.; Tiwari, S. Colloidal nanocarriers: a review on formulation technology, types and applications toward targeted drug delivery. Nanomedicine Nanotechnology, Biol. Med. 2010, 6, 9-24.

2. Storm, G.; Belliot, S.O.; Daemen, T.; Lasic, D.D. Surface modification of nanoparticles to oppose uptake by the mononuclear phagocyte system. Adv. Drug Deliv. Rev. 1995, 17, 3148.

3. Manaia, E.B.; Abuçafy, M.P.; Chiari-Andréo, B.G.; Silva, B.L.; Oshiro Junior, J.A.; Chiavacci, L.A. Physicochemical characterization of drug nanocarriers. Int. J. Nanomedicine 2017, 12, 4991-5011.

4. Barenholz, Y. Doxil® - The first FDA-approved nano-drug: Lessons learned. J. Control. Release 2012, 160, 117-134.

5. Miele, E.; Spinelli, G.P.; Miele, E.; Tomao, F.; Tomao, S. Albumin-bound formulation of paclitaxel (Abraxane ${ }^{\circledR}$ ABI-007) in the treatment of breast cancer. Int. J. Nanomedicine 2009, $4,99-105$.

6. $\quad$ Lee, K.S.; Chung, H.C.; Im, S.A.; Park, Y.H.; Kim, C.S.; Kim, S.B.; Rha, S.Y.; Lee, M.Y.; Ro, J. Multicenter phase II trial of Genexol-PM, a Cremophor-free, polymeric micelle formulation of paclitaxel, in patients with metastatic breast cancer. Breast Cancer Res. Treat. 2008, 108, 241-250.

7. Van Der Meel, R.; Oliveira, S.; Altintas, I.; Haselberg, R.; Van Der Veeken, J.; Roovers, R.C.; Van Bergen En Henegouwen, P.M.P.; Storm, G.; Hennink, W.E.; Schiffelers, R.M.; et al. Tumor-targeted Nanobullets: Anti-EGFR nanobody-liposomes loaded with anti-IGF-1R kinase inhibitor for cancer treatment. J. Control. Release 2012, 159, 281-289.

8. Chen, Y.; Zhang, F.; Wang, Q.; Tong, R.; Lin, H.; Qu, F. Near-infrared light-mediated LAUCNPs@SiO2-C/HA@mSiO2-DOX@NB nanocomposite for chemotherapy/PDT/PTT and imaging. Dalt. Trans. 2017, 46, 14293-14300.

9. Li, Z.; Tan, S.; Li, S.; Shen, Q.; Wang, K. Cancer drug delivery in the nano era: An overview and perspectives (Review). Oncol. Rep. 2017, 38, 611-624.

10. Ajnai, G.; Chiu, A.; Kan, T.; Cheng, C.C.; Tsai, T.H.; Chang, J. Trends of Gold Nanoparticlebased Drug Delivery System in Cancer Therapy. J. Exp. Clin. Med. 2014, 6, 172-178.

11. Tsuchida, K.; Murakami, T. Recent Advances in Inorganic Nanoparticle-Based Drug Delivery Systems. Mini-Reviews Med. Chem. 2008, 8, 175-183.

12. Arruebo, M.; Fernández-Pacheco, R.; Ibarra, M.R.; Santamaría, J. Magnetic nanoparticles for drug delivery. Nano Today 2007, 2, 22-32.

13. Tang, F.; Li, L.; Chen, D. Mesoporous silica nanoparticles: Synthesis, biocompatibility and drug delivery. Adv. Mater. 2012, 24, 1504-1534.

14. Rives, V.; Del Arco, M.; Martín, C. Layered double hydroxides as drug carriers and for controlled release of non-steroidal antiinflammatory drugs (NSAIDs): A review. J. Control. Release 2013, 169, 28-39.

15. Lohse, S.E.; Murphy, C.J. Applications of colloidal inorganic nanoparticles: From medicine to energy. J. Am. Chem. Soc. 2012, 134, 15607-15620.

16. Varga, N.; Benkő, M.; Sebők, D.; Bohus, G.; Janovák, L.; Dékány, I. Mesoporous silica coreshell composite functionalized with polyelectrolytes for drug delivery. Microporous Mesoporous Mater. 2015, 213, 134-141. 
17. Deák, Á.; Csapó, E.; Juhász, Á.; Dékány, I.; Janovák, L. Anti-ulcerant kynurenic acid molecules intercalated $\mathrm{Mg} / \mathrm{Al}$-layered double hydroxide and its release study. Appl. Clay Sci. 2018, 156, 28-35.

18. Allen, T.M.; Cullis, P.R. Liposomal drug delivery systems: From concept to clinical applications. Adv. Drug Deliv. Rev. 2013, 65, 36-48.

19. Karim, K.; Mandal, A.; Biswas, N.; Guha, A.; Chatterjee, S.; Behera, M.; Kuotsu, K. Niosome: A future of targeted drug delivery systems. J. Adv. Pharm. Technol. Res. 2010, 1, 374-380.

20. Singh, U.; Dar, M.M.; Hashmi, A.A. Dendrimers: Synthetic strategies, properties and applications. Orient. J. Chem. 2014, 30, 911-922.

21. Gillies, E.R.; Fréchet, J.M.J. Dendrimers and dendritic polymers in drug delivery. Drug Discov. Today 2005, 10, 35-43.

22. Elzoghby, A.O.; Samy, W.M.; Elgindy, N.A. Albumin-based nanoparticles as potential controlled release drug delivery systems. J. Control. Release 2012, 157, 168-182.

23. Varga, N.; Csapó, E.; Majláth, Z.; Ilisz, I.; Krizbai, I.A.; Wilhelm, I.; Knapp, L.; Toldi, J.; Vécsei, L.; Dékány, I. Targeting of the kynurenic acid across the blood-brain barrier by coreshell nanoparticles. Eur. J. Pharm. Sci. 2016, 86, 67-74.

24. Kovács, A.N.; Varga, N.; Gombár, G.; Hornok, V.; Csapó, E. Novel feasibilities for preparation of serum albumin-based core-shell nanoparticles in flow conditions. J. Flow Chem. 2020, 10, 497-505.

25. Kovács, A.N.; Varga, N.; Juhász, Á.; Csapó, E. Serum protein-hyaluronic acid complex nanocarriers: Structural characterisation and encapsulation possibilities. Carbohydr. Polym. 2021, 251, 117047.

26. Mora-Huertas, C.E.; Fessi, H.; Elaissari, A. Polymer-based nanocapsules for drug delivery. Int. J. Pharm. 2010, 385, 113-142.

27. Lee, J.H.; Yeo, Y. Controlled drug release from pharmaceutical nanocarriers. Chem. Eng. Sci. 2015, 125, 75-84.

28. Destribats, M.; Eyharts, M.; Lapeyre, V.; Sellier, E.; Varga, I.; Ravaine, V.; Schmitt, V. Impact of pNIPAM microgel size on its ability to stabilize pickering emulsions. Langmuir 2014, 30, 1768-1777.

29. Chamundeeswari, M.; Jeslin, J.; Verma, M.L. Nanocarriers for drug delivery applications. Environ. Chem. Lett. 2019, 17, 849-865.

30. Pridgen, E.M.; Langer, R.; Farokhzad, O.C. Biodegradable, polymeric nanoparticle delivery systems for cancer therapy. Nanomedicine 2007, 2, 669-680.

31. Pawar, D.; Mangal, S.; Goswami, R.; Jaganathan, K.S. Development and characterization of surface modified PLGA nanoparticles for nasal vaccine delivery: Effect of mucoadhesive coating on antigen uptake and immune adjuvant activity. Eur. J. Pharm. Biopharm. 2013, 85, $550-559$

32. de Britto, D.; de Moura, M.R.; Aouada, F.A.; Mattoso, L.H.C.; Assis, O.B.G. N,N,Ntrimethyl chitosan nanoparticles as a vitamin carrier system. Food Hydrocoll. 2012, 27, 487493.

33. Mittal, G.; Sahana, D.K.; Bhardwaj, V.; Ravi Kumar, M.N.V. Estradiol loaded PLGA nanoparticles for oral administration: Effect of polymer molecular weight and copolymer composition on release behavior in vitro and in vivo. J. Control. Release 2007, 119, 77-85. 
34. Mitra, S.; Gaur, U.; Ghosh, P.C.; Maitra, A.N. Tumour targeted delivery of encapsulated dextran-doxorubicin conjugate using chitosan nanoparticles as carrier. In Proceedings of the Journal of Controlled Release; Elsevier, 2001; 74, 317-323.

35. Yoo, H.S.; Lee, K.H.; Oh, J.E.; Park, T.G. In vitro and in vivo anti-tumor activities of nanoparticles based on doxorubicin-PLGA conjugates. J. Control. Release 2000, 68, 419431.

36. Wang, H.; Agarwal, P.; Zhao, S.; Xu, R.X.; Yu, J.; Lu, X.; He, X. Hyaluronic acid-decorated dual responsive nanoparticles of Pluronic F127, PLGA, and chitosan for targeted co-delivery of doxorubicin and irinotecan to eliminate cancer stem-like cells. Biomaterials 2015, 72, 7489.

37. Missirlis, D.; Kawamura, R.; Tirelli, N.; Hubbell, J.A. Doxorubicin encapsulation and diffusional release from stable, polymeric, hydrogel nanoparticles. Eur. J. Pharm. Sci. 2006, 29, 120-129.

38. Joshi, M.D.; Patravale, V.; Prabhu, R. Polymeric nanoparticles for targeted treatment in oncology: current insights. Int. J. Nanomedicine 2015, 10, 1001-1018,

39. Nitta, S.; Numata, K. Biopolymer-Based Nanoparticles for Drug/Gene Delivery and Tissue Engineering. Int. J. Mol. Sci. 2013, 14, 1629-1654,

40. Goldberg, M.; Langer, R.; Jia, X. Nanostructured materials for applications in drug delivery and tissue engineering. J. Biomater. Sci. Polym. Ed. 2007, 18, 241-268.

41. Torchilin, V.P. Multifunctional, stimuli-sensitive nanoparticulate systems for drug delivery. Nat. Rev. Drug Discov. 2014, 13, 813-827.

42. Sawant, R.M.; Hurley, J.P.; Salmaso, S.; Kale, A.; Tolcheva, E.; Levchenko, T.S.; Torchilin, V.P. "SMART" drug delivery systems: Double-targeted pH-responsive pharmaceutical nanocarriers. Bioconjug. Chem. 2006, 17, 943-949.

43. Rao, J.P.; Geckeler, K.E. Polymer nanoparticles: Preparation techniques and size-control parameters. Prog. Polym. Sci. 2011, 36, 887-913.

44. Nicolas, J.; Mura, S.; Brambilla, D.; Mackiewicz, N.; Couvreur, P. Design, functionalization strategies and biomedical applications of targeted biodegradable/biocompatible polymerbased nanocarriers for drug delivery. Chem. Soc. Rev. 2013, 42, 1147-1235

45. Quintanar-Guerrero, D.; Allémann, E.; Fessi, H.; Doelker, E. Preparation techniques and mechanisms of formation of biodegradable nanoparticles from preformed polymers. Drug Dev. Ind. Pharm. 1998, 24, 1113-1128

46. Vanderhoff, J.W., El Aasser. M.S., Ugelstad J., Polymer emulsification process. US Patent $4,177,177 ; \mathbf{1 9 7 9}$

47. Deshmukh, R.; Wagh, P.; Naik, J. Solvent evaporation and spray drying technique for microand nanospheres/particles preparation: A review. Dry. Technol. 2016, 34, 1758-1772.

48. G. Nava-Arzaluz, M.; Pinon-Segundo, E.; Ganem-Rondero, A.; Lechuga-Ballesteros, D. Single Emulsion-Solvent Evaporation Technique and Modifications for the Preparation of Pharmaceutical Polymeric Nanoparticles. Recent Pat. Drug Deliv. Formul. 2012, 6, 209-223.

49. Park, H.; Ha, D.-H.; Ha, E.-S.; Kim, J.-S.; Kim, M.-S.; Hwang, S.-J. Effect of Stabilizers on Encapsulation Efficiency and Release Behavior of Exenatide-Loaded PLGA Microsphere Prepared by the W/O/W Solvent Evaporation Method. Pharmaceutics 2019, 11, 627.

50. Iqbal, M.; Zafar, N.; Fessi, H.; Elaissari, A. Double emulsion solvent evaporation techniques used for drug encapsulation. Int. J. Pharm. 2015, 496, 173-190. 
51. Mendoza-Munoz, N.; Quintanar-Guerrero, D.; Allemann, E. The Impact of the Salting-Out Technique on the Preparation of Colloidal Particulate Systems for Pharmaceutical Applications. Recent Pat. Drug Deliv. Formul. 2012, 6, 236-249.

52. Fessi, H.; Puisieux, F.; Devissaguet, J.P.; Ammoury, N.; Benita, S. Nanocapsule formation by interfacial polymer deposition following solvent displacement. Int. J. Pharm. 1989, 55, R1-R4.

53. Hornig, S.; Heinze, T.; Becer, C.R.; Schubert, U.S. Synthetic polymeric nanoparticles by nanoprecipitation. J. Mater. Chem. 2009, 19, 3838-3840.

54. Bilati, U.; Allémann, E.; Doelker, E. Development of a nanoprecipitation method intended for the entrapment of hydrophilic drugs into nanoparticles. Eur. J. Pharm. Sci. 2005, 24, 6775 .

55. Poletto, F.S.; Fiel, L.A.; Donida, B.; Ré, M.I.; Guterres, S.S.; Pohlmann, A.R. Controlling the size of poly(hydroxybutyrate-co-hydroxyvalerate) nanoparticles prepared by emulsificationdiffusion technique using ethanol as surface agent. Colloids Surfaces A Physicochem. Eng. Asp. 2008, 324, 105-112.

56. Shakeri, F.; Shakeri, S.; Hojjatoleslami, M. Preparation and Characterization of Carvacrol Loaded Polyhydroxybutyrate Nanoparticles by Nanoprecipitation and Dialysis Methods. $J$. Food Sci. 2014, 79, N697-N705.

57. Zhang, Z.; Feng, S.S. In vitro investigation on poly(lactide)-tween 80 copolymer nanoparticles fabricated by dialysis method for chemotherapy. Biomacromolecules 2006, 7 , $1139-1146$.

58. Byrappa, K.; Ohara, S.; Adschiri, T. Nanoparticles synthesis using supercritical fluid technology - towards biomedical applications. Adv. Drug Deliv. Rev. 2008, 60, 299-327.

59. Liu, Z.; Jiao, Y.; Wang, Y.; Zhou, C.; Zhang, Z. Polysaccharides-based nanoparticles as drug delivery systems. Adv. Drug Deliv. Rev. 2008, 60, 1650-1662.

60. Bodnár, M.; Daróczi, L.; Batta, G.; Bakó, J.; Hartmann, J.F.; Borbély, J. Preparation and characterization of cross-linked hyaluronan nanoparticles. Colloid Polym. Sci. 2009, 287, 991-1000.

61. Ma, J.; Lee, S.M.Y.; Yi, C.; Li, C.W. Controllable synthesis of functional nanoparticles by microfluidic platforms for biomedical applications-a review. Lab Chip 2017, 17, 209-226.

62. Shrimal, P.; Jadeja, G.; Patel, S. A review on novel methodologies for drug nanoparticle preparation: Microfluidic approach. Chem. Eng. Res. Des. 2020, 153, 728-756.

63. Rezvantalab, S.; Keshavarz Moraveji, M. Microfluidic assisted synthesis of PLGA drug delivery systems. RSC Adv. 2019, 9, 2055-2072.

64. Lee, C.-Y.; Chang, C.-L.; Wang, Y.-N.; Fu, L.-M. Microfluidic Mixing: A Review. Int. J. Mol. Sci. 2011, 12, 3263-3287.

65. Karnik, R.; Gu, F.; Basto, P.; Cannizzaro, C.; Dean, L.; Kyei-Manu, W.; Langer, R.; Farokhzad, O.C. Microfluidic platform for controlled synthesis of polymeric nanoparticles. Nano Lett. 2008, 8, 2906-2912.

66. De Solorzano, I.O.; Uson, L.; Larrea, A.; Miana, M.; Sebastian, V.; Arruebo, M. Continuous synthesis of drug-loaded nanoparticles using microchannel emulsification and numerical modeling: Effect of passive mixing. Int. J. Nanomedicine 2016, 11, 3397-3416.

67. Auras, R. Poly(lactic acid), Encyclopedia of Polymer Science and Technology; John Wiley \& Sons, Inc.: Hoboken, NJ, USA, 2010, doi: 10.1002/0471440264.pst275 
68. Avérous, L. Polylactic acid: Synthesis, properties and applications. Monomers, Polymers and Composites from Renewable Resources; 2008; 433-450

69. da Silva, D.; Kaduri, M.; Poley, M.; Adir, O.; Krinsky, N.; Shainsky-Roitman, J.; Schroeder, A. Biocompatibility, biodegradation and excretion of polylactic acid (PLA) in medical implants and theranostic systems. Chem. Eng. J. 2018, 340, 9-14.

70. Carothers, W.H.; Borough, G.L.; Natta, F.J. Studies of polymerization and ring formation. X. The reversible polymerization of six-membered cyclic esters. J. Am. Chem. Soc. 1932, 54, 761-772.

71. Laopaiboon, P.; Thani, A.; Leelavatcharamas, V.; Laopaiboon, L. Acid hydrolysis of sugarcane bagasse for lactic acid production. Bioresour. Technol. 2010, 101, 1036-1043.

72. Adsul, M.G.; Varma, A.J.; Gokhale, D. V. Lactic acid production from waste sugarcane bagasse derived cellulose. Green Chem. 2007, 9, 58-62.

73. Castillo Martinez, F.A.; Balciunas, E.M.; Salgado, J.M.; Domínguez González, J.M.; Converti, A.; Oliveira, R.P. de S. Lactic acid properties, applications and production: A review. Trends Food Sci. Technol. 2013, 30, 70-83.

74. $\quad$ Lasprilla, A.J.R.; Martinez, G.A.R.; Lunelli, B.H.; Jardini, A.L.; Filho, R.M. Poly-lactic acid synthesis for application in biomedical devices - A review. Biotechnol. Adv. 2012, 30, 321328.

75. Pyda, M.; Bopp, R.C.; Wunderlich, B. Heat capacity of poly(lactic acid). J. Chem. Thermodyn. 2004, 36, 731-742.

76. Lim, L.T.; Auras, R.; Rubino, M. Processing technologies for poly(lactic acid). Prog. Polym. Sci. 2008, 33, 820-852.

77. Houchin, M.L.; Topp, E.M. Chemical degradation of peptides and proteins in PLGA: A review of reactions and mechanisms. J. Pharm. Sci. 2008, 97, 2395-2404.

78. Chen, G.X.; Kim, H.S.; Kim, E.S.; Yoon, J.S. Synthesis of high-molecular-weight poly(1lactic acid) through the direct condensation polymerization of 1-lactic acid in bulk state. Eur. Polym. J. 2006, 42, 468-472.

79. Gu, S.; Yang, M.; Yu, T.; Ren, T.; Ren, J. Synthesis and characterization of biodegradable lactic acid-based polymers by chain extension. Polym. Int. 2008, 57, 982-986.

80. Mehta, R.; Kumar, V.; Bhunia, H.; Upadhyay, S.N. Synthesis of poly(lactic acid): A review. J. Macromol. Sci. - Polym. Rev. 2005, 45, 325-349.

81. D'Avila Carvalho Erbetta, C. Synthesis and Characterization of Poly(D,L-Lactide-coGlycolide) Copolymer. J. Biomater. Nanobiotechnol. 2012, 03, 208-225.

82. Silva, A.T.C.R.; Cardoso, B.C.O.; Silva, M.E.S.R. e; Freitas, R.F.S.; Sousa, R.G. Synthesis, Characterization, and Study of PLGA Copolymer in Vitro Degradation. J. Biomater. Nanobiotechnol. 2015, 06, 8-19.

83. Danhier, F.; Ansorena, E.; Silva, J.M.; Coco, R.; Le Breton, A.; Préat, V. PLGA-based nanoparticles: An overview of biomedical applications. J. Control. Release 2012, 161, 505522.

84. Astete, C.E.; Sabliov, C.M. Synthesis and characterization of PLGA nanoparticles. $J$. Biomater. Sci. Polym. Ed. 2006, 17, 247-289.

85. Kiss, É.; Gyulai, G.; Pénzes, C.B.; Idei, M.; Horváti, K.; Bacsa, B.; Bosze, S. Tuneable surface modification of PLGA nanoparticles carrying new antitubercular drug candidate. Colloids Surfaces A Physicochem. Eng. Asp. 2014, 458, 178-186. 
86. Gyulai, G.; Magyar, A.; Rohonczy, J.; Orosz, J.; Yamasaki, M.; Bősze, S.; Kiss Preparation and characterization of cationic pluronic for surface modification and functionalization of polymeric drug delivery nanoparticles. Express Polym. Lett. 2016, 10, 216-226.

87. Huang, W.; Zhang, C. Tuning the Size of Poly(lactic-co-glycolic Acid) (PLGA) Nanoparticles Fabricated by Nanoprecipitation. Biotechnol. J. 2018, 13, 1700203.

88. Lancheros, R.; Guerrero, C.A.; Godoy-Silva, R.D. Improvement of N-Acetylcysteine Loaded in PLGA Nanoparticles by Nanoprecipitation Method. J. Nanotechnol. 2018, 2018, doi:. $10.1155 / 2018 / 3620373$

89. Barichello, J.M.; Morishita, M.; Takayama, K.; Nagai, T. Encapsulation of Hydrophilic and Lipophilic Drugs in PLGA Nanoparticles by the Nanoprecipitation Method. Drug Dev. Ind. Pharm. 1999, 25, 471-476.

90. Sze, J.H.; Brownlie, J.C.; Love, C.A. Biotechnological production of hyaluronic acid: a mini review. 3 Biotech 2016, 6, 1-9.

91. Necas, J.; Bartosikova, L.; Brauner, P.; Kolar, J. Hyaluronic acid (hyaluronan): A review. Vet. Med. (Praha). 2008, 53, 397-411.

92. Huang, G.; Huang, H. Hyaluronic acid-based biopharmaceutical delivery and tumor-targeted drug delivery system. J. Control. Release 2018, 278, 122-126.

93. Dicker, K.T.; Gurski, L.A.; Pradhan-Bhatt, S.; Witt, R.L.; Farach-Carson, M.C.; Jia, X. Hyaluronan: A simple polysaccharide with diverse biological functions. Acta Biomater. 2014, $10,1558-1570$.

94. Salwowska, N.M.; Bebenek, K.A.; Żądło, D.A.; Wcisło-Dziadecka, D.L. Physiochemical properties and application of hyaluronic acid: a systematic review. J. Cosmet. Dermatol. 2016, 15, 520-526.

95. Athamneh, T.; Amin, A.; Benke, E.; Ambrus, R.; Leopold, C.S.; Gurikov, P.; Smirnova, I. Alginate and hybrid alginate-hyaluronic acid aerogel microspheres as potential carrier for pulmonary drug delivery. J. Supercrit. Fluids 2019, 150, 49-55.

96. Falcone, S.J.; Berg, R.A. Crosslinked hyaluronic acid dermal fillers: A comparison of rheological properties. J. Biomed. Mater. Res. Part A 2008, 87A, 264-271.

97. Venerová, T.; Pekař, M. Rheological properties of gels formed by physical interactions between hyaluronan and cationic surfactants. Carbohydr. Polym. 2017, 170, 176-181.

98. Dodero, A.; Williams, R.; Gagliardi, S.; Vicini, S.; Alloisio, M.; Castellano, M. A microrheological and rheological study of biopolymers solutions: Hyaluronic acid. Carbohydr. Polym. 2019, 203, 349-355.

99. Luo, Z.; Dai, Y.; Gao, H. Development and application of hyaluronic acid in tumor targeting drug delivery. Acta Pharm. Sin. B 2019, 9, 1099-1112.

100. Zhang, J.; Senger, B.; Vautier, D.; Picart, C.; Schaaf, P.; Voegel, J.C.; Lavalle, P. Natural polyelectrolyte films based on layer-by layer deposition of collagen and hyaluronic acid. Biomaterials 2005, 26, 3353-3361.

101. Tian, H.; He, Z.; Sun, C.; Yang, C.; Zhao, P.; Liu, L.; Leong, K.W.; Mao, H.-Q.; Liu, Z.; Chen, Y. Uniform Core-Shell Nanoparticles with Thiolated Hyaluronic Acid Coating to Enhance Oral Delivery of Insulin. Adv. Healthc. Mater. 2018, 7, 1800285.

102. Luo, Y.; Kirker, K.R.; Prestwich, G.D. Cross-linked hyaluronic acid hydrogel films: New biomaterials for drug delivery. J. Control. Release 2000, 69, 169-184. 
103. Pitarresi, G.; Craparo, E.F.; Palumbo, F.S.; Carlisi, B.; Giammona, G. Composite nanoparticles based on hyaluronic acid chemically cross-linked with $\alpha, \beta-$ polyaspartylhydrazide. Biomacromolecules 2007, 8, 1890-1898.

104. Maroda, M.; Bodnár, M.; Berkó, S.; Bakó, J.; Er̈s, G.; Csányi, E.; Szabó-Révész, P.; Hartmann, J.F.; Kemény, L.; Borbély, J. Preparation and investigation of a cross-linked hyaluronan nanoparticles system. Carbohydr. Polym. 2011, 83, 1322-1329.

105. Berkó, S.; Maroda, M.; Bodnár, M.; Eros, G.; Hartmann, P.; Szentner, K.; Szabó-Révész, P.; Kemény, L.; Borbély, J.; Csányi, E. Advantages of cross-linked versus linear hyaluronic acid for semisolid skin delivery systems. Eur. Polym. J. 2013, 49, 2511-2517.

106. Tiwari, S.; Bahadur, P. Modified hyaluronic acid based materials for biomedical applications. Int. J. Biol. Macromol. 2019, 121, 556-571.

107. Miranda, D.G.; Malmonge, S.M.; Campos, D.M.; Attik, N.G.; Grosgogeat, B.; Gritsch, K. A chitosan-hyaluronic acid hydrogel scaffold for periodontal tissue engineering. J. Biomed. Mater. Res. Part B Appl. Biomater. 2016, 104, 1691-1702.

108. Bendix, D. Chemical synthesis of polylactide and its copolymers for medical applications. Polym. Degrad. Stab. 1998, 59, 129-135.

109. Juhász, Á.; Tabajdi, R.; Dékány, I.; Csapó, E. Thermodynamic Characterization of Temperature- and Composition-Dependent Mixed Micelle Formation in Aqueous Medium. J. Surfactants Deterg. 2017, 20, 1291-1299.

110. Peppas, N.A.; Sahlin, J.J. A simple equation for the description of solute release. III. Coupling of diffusion and relaxation. Int. J. Pharm. 1989, 57, 169-172.

111. Costa, P.; Sousa Lobo, J.M. Modeling and comparison of dissolution profiles. Eur. J. Pharm. Sci. 2001, 13, 123-133.

112. Dash, S.; Murthy, P.N.; Nath, L.; Chowdhury, P. Kinetic modeling on drug release from controlled drug delivery systems. Acta Pol. Pharm. - Drug Res. 2010, 67, 217-223.

113. Reich, G. Use of DSC to study the degradation behavior of PLA and PLGA microparticles. Drug Dev. Ind. Pharm. 1997, 23, 1177-1189.

114. Jamshidian, M.; Tehrany, E.A.; Imran, M.; Jacquot, M.; Desobry, S. Poly-Lactic Acid: Production, applications, nanocomposites, and release studies. Compr. Rev. Food Sci. Food Saf. 2010, 9, 552-571.

115. Duhem, N.; Danhier, F.; Préat, V. Vitamin E-based nanomedicines for anti-cancer drug delivery. J. Control. Release 2014, 182, 33-44.

116. Zigoneanu, I.G.; Astete, C.E.; Sabliov, C.M. Nanoparticles with entrapped $\alpha$-tocopherol: Synthesis, characterization, and controlled release. Nanotechnology 2008, 19, 105606.

117. Deák, Á.; Sebők, D.; Csapó, E.; Bérczi, A.; Dékány, I.; Zimányi, L.; Janovák, L. Evaluation of $\mathrm{pH}$ - responsive poly(styrene-co-maleic acid) copolymer nanoparticles for the encapsulation and $\mathrm{pH}$ - dependent release of ketoprofen and tocopherol model drugs. Eur. Polym. J. 2019, 114, 361-368.

118. Yokogawa, K.; Shima, Y.; Hashimoto, T.; Hiyajyo, M.; Kadoyama, K.; Ishizaki, J.; Nomura, M.; Miyamoto, K.I. High Bioavailabilty of $\alpha$-Tocopherol Loaded into Poly (DL-Lactic-coGlycolic Acid) Microspheres in Apolipoprotein B Knockout Mice. Pharm. Res. 2003, 20, $1846-1850$.

119. Mannila, A.; Kokki, H.; Heikkinen, M.; Laisalmi, M.; Lehtonen, M.; Louhisto, H.L.; Järvinen, T.; Savolainen, J. Cerebrospinal fluid distribution of ketoprofen after intravenous administration in young children. Clin. Pharmacokinet. 2006, 45, 737-743. 
120. Niki, E.; Abe, K. CHAPTER 1: Vitamin E: Structure, Properties and Functions. In Food Chemistry, Function and Analysis; Royal Society of Chemistry, 2019; 2019-January, 1-11

121. Simon, L.C.; Stout, R.W.; Sabliov, C. Bioavailability of Orally Delivered Alpha-Tocopherol by Poly(Lactic-Co-Glycolic) Acid (PLGA) Nanoparticles and Chitosan Covered PLGA Nanoparticles in F344 Rats. Nanobiomedicine 2016, 3, 8.

122. Murugeshu, A.; Astete, C.; Leonardi, C.; Morgan, T.; Sabliov, C.M. Chitosan/PLGA particles for controlled release of $\alpha$-tocopherol in the GI tract via oral administration. Nanomedicine 2011, 6, 1513-1528.

123. Alqahtani, S.; Simon, L.; Astete, C.E.; Alayoubi, A.; Sylvester, P.W.; Nazzal, S.; Shen, Y.; $\mathrm{Xu}, \mathrm{Z}$; Kaddoumi, A.; Sabliov, C.M. Cellular uptake, antioxidant and antiproliferative activity of entrapped $\alpha$-tocopherol and $\gamma$-tocotrienol in poly (lactic-co-glycolic) acid (PLGA) and chitosan covered PLGA nanoparticles (PLGA-Chi). J. Colloid Interface Sci. 2015, 445, 243-251.

124. Byun, Y.; Hwang, J.B.; Bang, S.H.; Darby, D.; Cooksey, K.; Dawson, P.L.; Park, H.J.; Whiteside, S. Formulation and characterization of $\alpha$-tocopherol loaded poly e\{open\}caprolactone (PCL) nanoparticles. LWT - Food Sci. Technol. 2011, 44, 24-28.

125. Quintero, C.; Vera, R.; Perez, L.D. $\alpha$-Tocopherol loaded thermosensitive polymer nanoparticles: Preparation, in vitro release and antioxidant properties. Polimeros 2016, 26, 304-312.

126. Che Man, Y.B.; Ammawath, W.; Mirghani, M.E.S. Determining $\alpha$-tocopherol in refined bleached and deodorized palm olein by Fourier transform infrared spectroscopy. Food Chem. 2005, 90, 323-327.

127. Seedher, N.; Kanojia, M. Micellar solubilization of some poorly soluble antidiabetic drugs: A technical note. AAPS PharmSciTech 2008, 9, 431-436.

128. Butt, A.M.; Amin, M.C.I.M.; Katas, H.; Sarisuta, N.; Witoonsaridsilp, W.; Benjakul, R. In vitro characterization of pluronic F127 and D- $\alpha$-tocopheryl polyethylene glycol 1000 succinate mixed micelles as nanocarriers for targeted anticancer-drug delivery. J. Nanomater. 2012, 2012.

129. Lopes, J.R.; Loh, W. Investigation of self-assembly and micelle polarity for a wide range of ethylene oxide-propylene oxide-ethylene oxide block copolymers in water. Langmuir 1998, $14,750-756$.

130. Bouchemal, K.; Agnely, F.; Koffi, A.; Ponchel, G. A concise analysis of the effect of temperature and propanediol-1, 2 on Pluronic F127 micellization using isothermal titration microcalorimetry. J. Colloid Interface Sci. 2009, 338, 169-176.

131. Ritger, P.L.; Peppas, N.A. A simple equation for description of solute release I. Fickian and non-fickian release from non-swellable devices in the form of slabs, spheres, cylinders or discs. J. Control. Release 1987, 5, 23-36.

132. Alkrad, J.A.; Mrestani, Y.; Stroehl, D.; Wartewig, S.; Neubert, R. Characterization of enzymatically digested hyaluronic acid using NMR, Raman, IR, and UV-Vis spectroscopies. J. Pharm. Biomed. Anal. 2003, 31, 545-550.

133. Servaty, R.; Schiller, J.; Binder, H.; Arnold, K. Hydration of polymeric components of cartilage - An infrared spectroscopic study on hyaluronic acid and chondroitin sulfate. Int. J. Biol. Macromol. 2001, 28, 121-127.

134. Barbucci, R.; Consumi, M.; Magnani, A. Dependence of water uptake and morphology of hyaluronan- and alginate-based hydrogels on $\mathrm{pH}$ and degree of crosslinking. Macromol. Chem. Phys. 2002, 203, 1292-1300. 
135. Tomihata, K.; Ikada, Y. Crosslinking of hyaluronic acid with water-soluble carbodiimide. $J$. Biomed. Mater. Res. 1997, 37, 243-251.

136. Barbucci, R.; Rappuoli, R.; Borzacchiello, A.; Ambrosio, L. Synthesis, chemical and rheological characterization of new hyaluronic acid-based hydrogels. J. Biomater. Sci. Polym. Ed. 2000, 11, 383-399.

137. Li, N.; Liu, S.; Luo, H. A new method for the determination of the first and second CMC in CTAB solution by resonance Rayleigh scattering technology. Anal. Lett. 2002, 35, 12291238.

138. Modaressi, A.; Sifaoui, H.; Grzesiak, B.; Solimando, R.; Domanska, U.; Rogalski, M. CTAB aggregation in aqueous solutions of ammonium based ionic liquids; conductimetric studies. Colloids Surfaces A Physicochem. Eng. Asp. 2007, 296, 104-108.

139. Kargerová, A.; Pekař, M. High-Resolution Ultrasonic Spectroscopy Study of Interactions between Hyaluronan and Cationic Surfactants. Langmuir 2014, 30, 11866-11872.

140. Krouská, J.; Pekař, M.; Klučáková, M.; Šarac, B.; Bešter-Rogač, M. Study of interactions between hyaluronan and cationic surfactants by means of calorimetry, turbidimetry, potentiometry and conductometry. Carbohydr. Polym. 2017, 157, 1837-1843.

141. Krutišová, T.; Hejná, J.; Pekař, M. Nanoparticles Formed By Self-Assembly Of Negatively Charged Hyaluronan And Cationic Surfactant, Conference Proceedings of 5th Anniversary International Conference on Nanomaterials - Research \& Application, October 16th - 18th 2013, Brno, Czech Republic, 595-599.

142. Pilgrová, T.; Pekař, M. Interaction between cationic micelles and hyaluronan. Materials Science Forum; Trans Tech Publications Ltd, 2016; 851, 26-31.

143. Ambrosio, L.; Borzacchiello, A.; Netti, P.A.; Nicolais, L. Properties of new materials: Rheological study on hyaluronic acid and its derivative solutions. J. Macromol. Sci. - Pure Appl. Chem. 1999, 36 A, 991-1000.

144. Liang, J.; Krause, W.E.; Liang, J.; Krause, W.E. Rheology and lubricity of hyaluronic acid. APS 2007, N25.009.

145. Ravi Kumar, M.N.V. A review of chitin and chitosan applications. React. Funct. Polym. 2000, $46,1-27$.

146. Wang, S.; Shao, G.; Yang, J.; Liu, J.; Wang, J.; Zhao, H.; Yang, L.; Liu, H.; Zhu, D.; Li, Y.; et al. The production of gel beads of soybean hull polysaccharides loaded with soy isoflavone and their pH-dependent release. Food Chem. 2020, 313, 126095.

147. Wang, Q.Z.; Chen, X.G.; Liu, N.; Wang, S.X.; Liu, C.S.; Meng, X.H.; Liu, C.G. Protonation constants of chitosan with different molecular weight and degree of deacetylation. Carbohydr. Polym. 2006, 65, 194-201.

148. Xu, Y.X.; Kim, K.M.; Hanna, M.A.; Nag, D. Chitosan-starch composite film: Preparation and characterization. Ind. Crops Prod. 2005, 21, 185-192.

149. Huang, S.; Song, X.; Li, T.; Xiao, J.; Chen, Y.; Gong, X.; Zeng, W.; Yang, L.; Chen, C. Pellet coculture of osteoarthritic chondrocytes and infrapatellar fat pad-derived mesenchymal stem cells with chitosan/hyaluronic acid nanoparticles promotes chondrogenic differentiation. Stem Cell Res. Ther. 2017, 8, 264. 


\section{Melléklet}
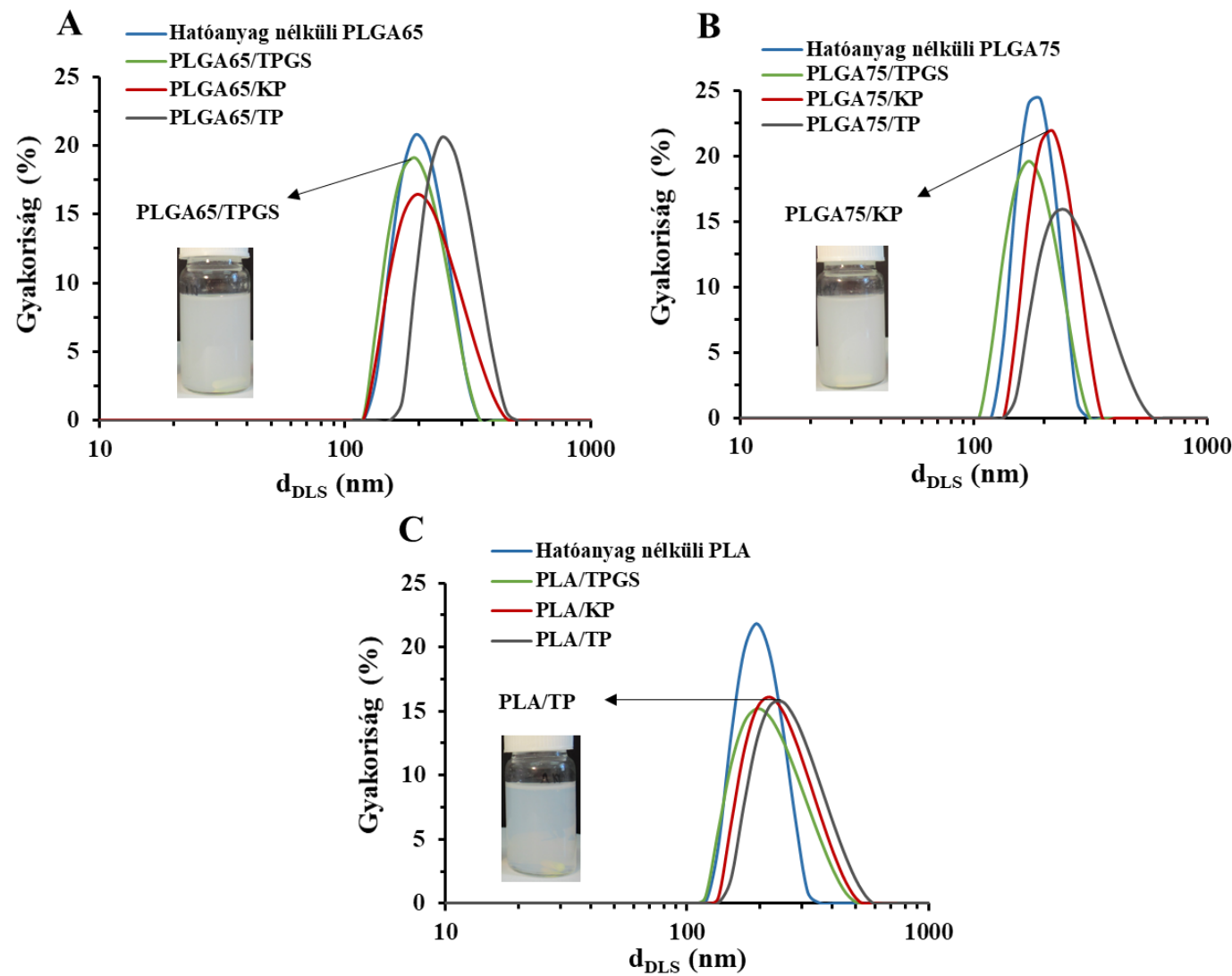

M46. ábra: Hatóanyag nélküli és hatóanyag-tartalmú (A) PLGA65, (B) PLGA75 és (C) PLA méreteloszlási görbéi (szerves fázis: $\mathrm{C}_{\mathrm{PLA} / \mathrm{PLGA}}=10 \mathrm{mg} / \mathrm{mL}, \mathrm{V}=1,5 \mathrm{~mL}$; vizes fázis:

$$
\mathrm{C}_{\text {PLUR }}=0,1 \mathrm{mg} / \mathrm{mL}, \mathrm{V}=15 \mathrm{~mL} ; \mathrm{m}_{\text {hatóanyag }}=7,5 \mathrm{mg} \text { ) }
$$



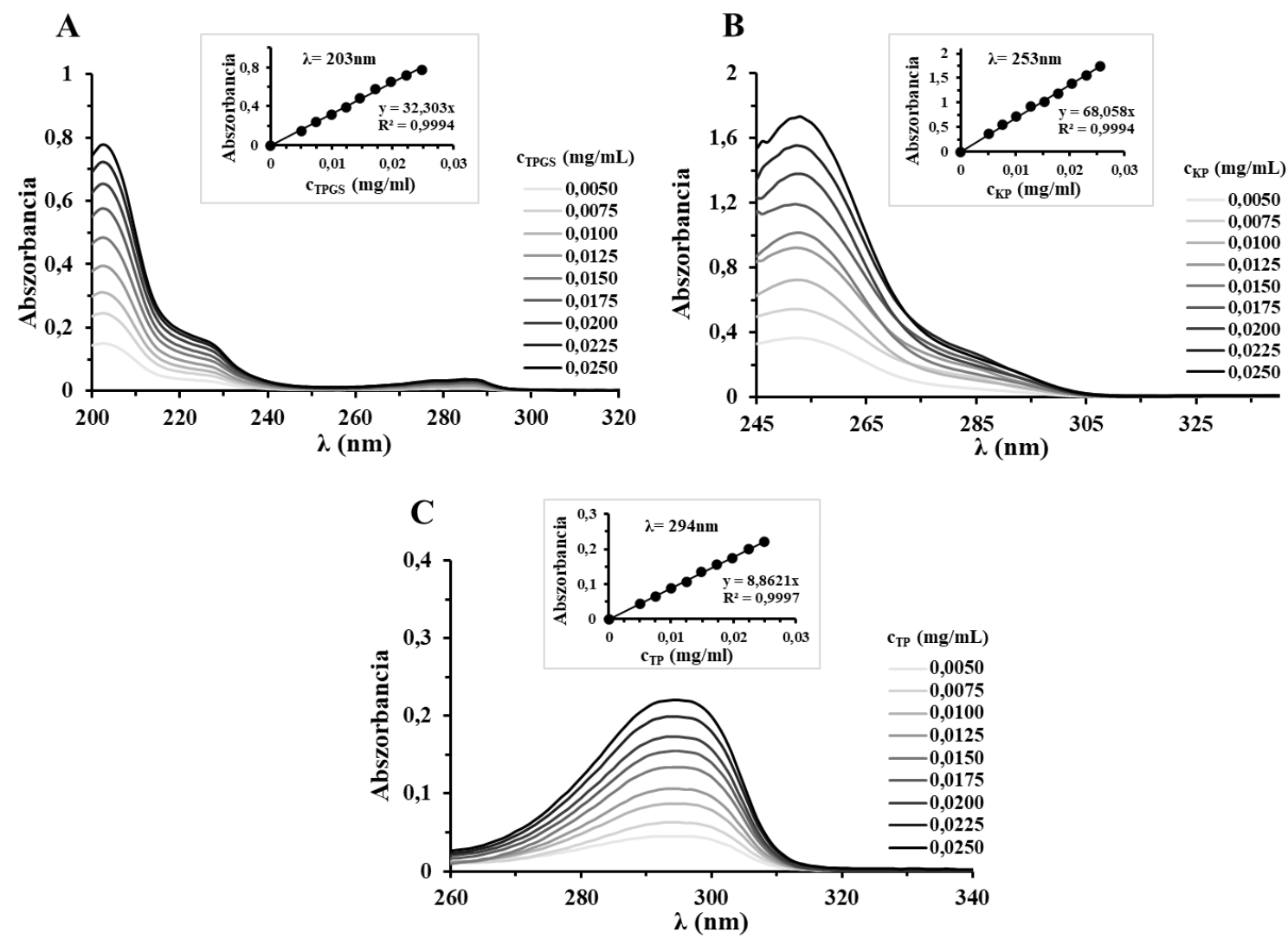

M47. ábra: (A) D- $\alpha$-tokoferol-polietilén-glikol-1000-szukcinát, (B) ketoprofen és (C) ( \pm )$\alpha$-tokoferol hatóanyagok UV-Vis spektrofotometriás módszerrel meghatározott kalibrációs spektrumai nagytisztaságú Milli-Q vizes közegben és a hozzájuk tartozó kalibrációs egyenesek 

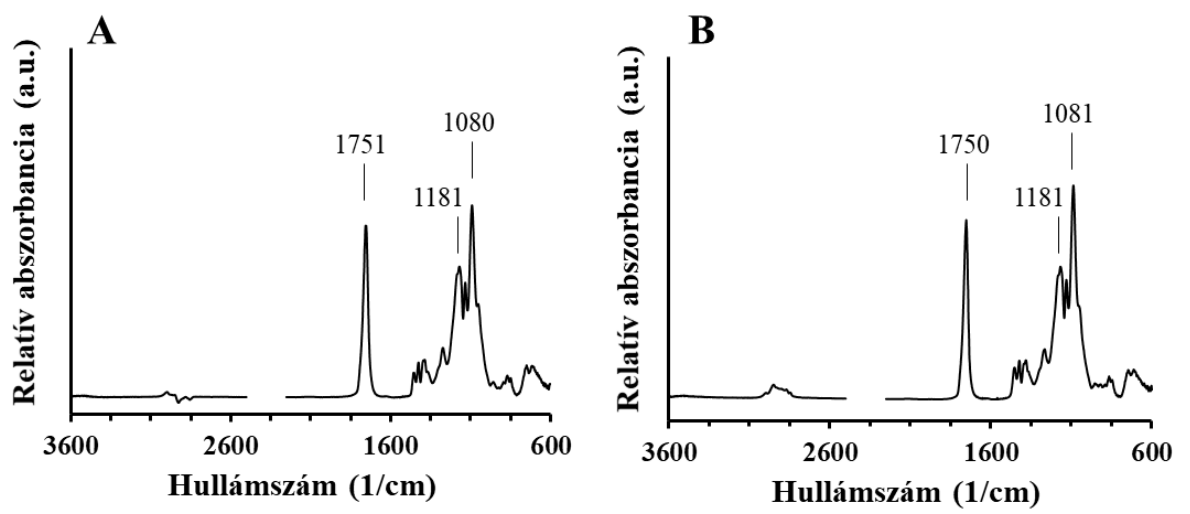

M48. ábra: (A) TP-nélküli és (B) TP-tartalmú PLGA65 részecskék FT-IR spektrumai (szerves fázis: $\mathrm{c}_{\mathrm{PLA}}=10 \mathrm{mg} / \mathrm{mL}, \mathrm{c}_{\mathrm{TP}}=2,5 \mathrm{mg} / \mathrm{mL}$; vizes fázis: $\mathrm{c}_{\mathrm{PLUR}}=0,1 \mathrm{mg} / \mathrm{mL}$ )

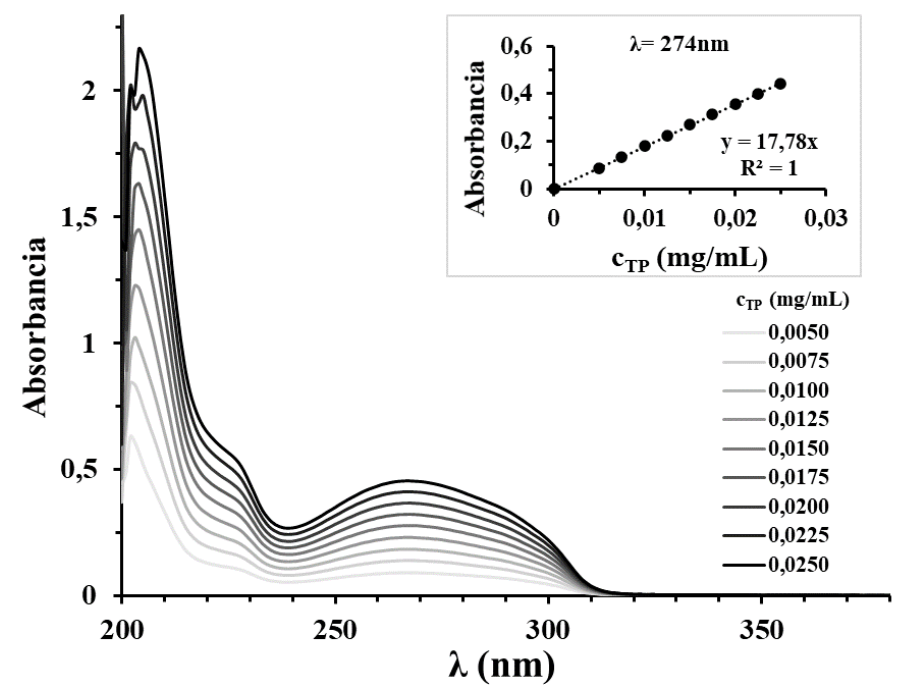

M49. ábra: A TP UV spektrumai és a meghatározott kalibrációs egyenes PBS közegben $\left(\mathrm{pH}=7,4 ; 0,9 \% \mathrm{NaCl} ; \mathrm{c}_{\mathrm{PLUR}}=1 \mathrm{mg} / \mathrm{mL}\right)$

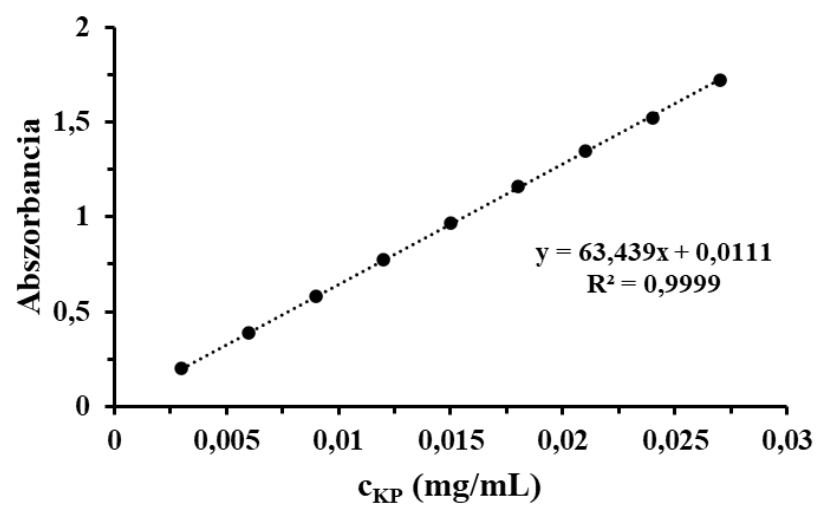

M50. ábra: A KP UV-Vis spetrofotometriás módszerrel meghatározott kalibrációs egyenese PBS közegben ( $\left.\mathrm{pH}=7,4 ; 0,9 \% \mathrm{NaCl}, \lambda_{\max }=260 \mathrm{~nm}\right)$ 


\section{Köszönetnyilvánítás}

Ezúton szeretném megköszönni témavezetőmnek, Dr. Juhászné Dr. Csapó Editnek, hogy meglátásaival és szakmai útmutatásával mindvégig támogatta doktori munkámat, illetve lehetővé tette számomra, hogy a kutatási tevékenységemet az általa vezetett Kutatócsoportban végezhessem.

Köszönettel tartozom Prof. Dr. Tóth Ágotának, a SZTE TTIK Fizikai Kémiai és Anyagtudományi Tanszék vezetőjének, aki biztosította részemre, hogy a disszertációval kapcsolatos kutatómunkámat az Általa vezetett tanszéken végezhessem. Külön köszönöm Prof. Dr. Janáky Tamásnak a lehetőséget, hogy a doktori munkám során közremüködő kutatóként dolgozhattam az általa irányított „Új gyógyszer hatóanyagok és célba juttatások új hordozórendszerekkel” projekt keretein belül.

Köszönet illeti Prof. Dr. Dékány Imre akadémikust és Dr. Janovák Lászlót, akik időnként hasznos elméleti és gyakorlati tanácsokkal segítették kutatómunkám.

Továbbá köszönöm a Kutatócsoportunk valamennyi volt és jelenlegi munkatársának, főként Turcsányi Arpádnak, Dr. Varga Viktóriának, Kovács Nikolett Alexandrának, Dr. Juhász Ádámnak, Janóné Dr. Ungor Ditta Anitának, Marótiné Szokolai Hajnalkának és Gombár Gyöngyinek, a kutatómunkámhoz nyújtott segítségüket és baráti támogatásukat, mellyel hozzájárultak a disszertációm megszületéséhez.

Hálás szívvel köszönöm menyasszonyomnak a szüntelen gondoskodását és szeretetét, mellyel végig kísérte és segítette egyetemi éveimet. Végül szeretném megköszönni a családomnak és barátaimnak, hogy kitartó támogatásukkal és bíztató szavakkal mindvégig mellettem álltak.

A kutatómunka dologi hátterét a GINOP-2.3.2-15-2016-00060 azonositó számmal rendelkezö „Új gyógyszer hatóanyagok és célba juttatásuk új hordozórendszerekkel”, pályázati projekt biztosította 2017-töl.

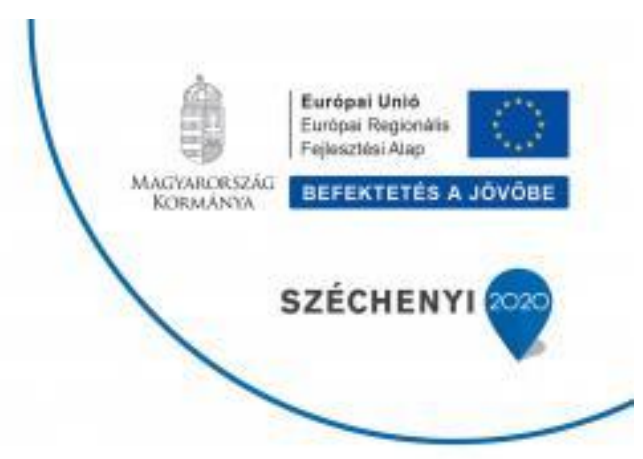




\section{Publikációs lista}

Magyar Tudományos Müvek Tára (MTMT) azonosító: 10067813

A doktori munkához közvetlenül kapcsolódó tudományos közlemények:

[1] Á. Turcsányi, N. Varga, E. Csapó, Chitosan-modified hyaluronic acid-based nanosized drug carriers, International Journal of Biological Macromolecules, 148 (2020) 218-225, doi: 10.1016/j.ijbiomac.2020.01.118

$$
\mathrm{IF}_{2019}=5,162
$$

[2] N. Varga, Á. Turcsányi, V. Hornok, E. Csapó, Vitamin E-Loaded PLA- and PLGABased Core-Shell Nanoparticles: Synthesis, Structure Optimization and Controlled Drug Release, Pharmaceutics, 11 (2019), 357, doi: 10.3390/pharmaceutics11070357

$$
\mathrm{IF}_{2019}=4,421
$$

[3] N. Varga, V. Hornok, L. Janovák, I. Dékány, E. Csapó, The effect of synthesis conditions and tunable hydrophilicity on the drug encapsulation capability of PLA and PLGA nanoparticles, Colloids and Surfaces B: Biointefaces, 176 (2019) 212-218. doi: 10.1016/j.colsurfb.2019.01.012

$\mathrm{IF}_{2019}=4,389$

[4] E. Csapó, H. Szokolai, Á. Juhász, N. Varga, L. Janovák, I. Dékány, Cross-linked and hydrophobized hyaluronic acid-based controlled drug release systems, Carbohydrate Polymers, 195 (2018) 99-106, doi: 10.1016/j.carbpol.2018.04.073

$$
\mathrm{IF}_{2018}=6,044
$$

[5] Á. Juhász, N. Varga, Á. Turcsányi, E. Csapó, Relation between Rheological, Structural and Dissolution Properties of Covalently and Ionically Modified Hyaluronic Acid-based Drug Carriers, Conference Proceedings of 10th Anniversary International Conference on Nanomaterials - Research \& Application, October 17th 19th 2018, Brno, Czech Republic, pp.330-336, ISBN 978-80-87294-89-5.

$$
\Sigma \text { IF }=20,016
$$




\section{Egyéb tudományos közlemények:}

[6] A. N. Kovács, N. Varga, Á. Juhász, E. Csapó, Serum protein-hyaluronic acid complex nanocarriers: structural characterisation and encapsulation possibilities,

Carbohydrate Polymers, 251 (2020), doi: 10.1016/j.carbpol.2020.117047

$\mathrm{IF}_{2019}=7,182$

[7] A. N. Kovács, N. Varga, Gy. Gombár, V. Hornok, E. Csapó, Novel feasibilities for preparation of serum albumin-based core-shell nanoparticles in flow conditions, Journal of Flow Chemistry, 10 (2020), 497-505 doi: 10.1007/s41981-020-00088-4

$\mathrm{IF}_{2019}=3,622$

[8] L. Mérai, N. Varga, Á. Deák, D. Sebők, I. Szenti, Á. Kukovecz, Z. Kónya, I. Dékány, L. Janovák, Preparation of photocatalytic thin films with composition dependent wetting properties and self-healing ability, Catalysis Today, 328 (2019) 85-90. doi: 10.1016/j.cattod.2018.10.015

$\mathrm{IF}_{2019}=5,825$

[9] B. Kutus, N. Varga, G. Peintler, A. Lupan, A. A. A. Attia, I. Pálinkó, P. Sipos, Formation of mono- and binuclear neodymium(III)-gluconate complexes in aqueous solutions in the pH range 2-8, Dalton Transactions 46 (2017) 6049-6058, doi: 10.1039/C7DT00909G

$$
\mathrm{IF}_{2017}=4,099
$$

[10] B. Kutus, D. Ozsvár, ‥ Varga, I. Pálinkó, P. Sipos, ML and ML2 complex formation between Ca (II) and D-glucose derivatives in aqueous solutions, Dalton Transactions 46 (2017) 1065-1074, doi: 10.1039/C6DT04356A

$\mathrm{IF}_{2017}=4,099$

$$
\Sigma \text { IF }=24,827
$$

$\Sigma \Sigma$ IF $=44,843$ 